\title{
Actually or Potentially Within Reach: The Place of China in New Zealand's Grand Strategy 1965-1972
}

\section{David Belgrave}

requirements for the degree of Doctor of Philosophy

Victoria University of Wellington 
In 1965 New Zealand was an active member of alliances designed to contain the People's Republic of China in South East Asia. Late the previous year, the Defence Council had warned Cabinet that New Zealand could be at war with China and/or Indonesia in six months. Less than seven years later New Zealand recognised China, as Britain and the US military presences were exiting from South East Asia. These events bookend a radical reshaping of New Zealand's defence policies and its attitude towards China.

The existing scholarship on New Zealand's Cold War defence policies has underemphasised the role of China in New Zealand's grand strategy and the scholarship on Sino-New Zealand relations has also largely ignored defence policy. This thesis uses recently released files from the Ministry of Defence to provide new insight into the construction of China as a threat during the mid-1960s and the challenges faced in meeting that perceived threat. New Zealand's Forward Defence policy was one designed to contain China and Beijing-supported revolutionary groups in South East Asia. This strategy was predicated on active British or American support for containment. SEATO and ANZAM provided the basis of New Zealand war planning and day-to-day operations in Asia respectively. With the British decision to withdraw from South East Asia and the American quagmire in Vietnam, New Zealand had to reassess its position in South East Asia as containment of China was no longer thought possible.

The need for a containment strategy was based upon a conceptualisation of China as a growing and hostile power. This view saw China as eventually developing the means to dominate South East Asia and threaten Australasia directly as Japan had done in 1942. This perception of China changed with the emergence of the Cultural Revolution. New Zealand officials watched from Hong Kong as violence and mass political disorder challenged established sources of authority. They took the view that Mao was in direct command of the revolution and was placing limits on it. The revolution destroyed the notion that China was a growing power bent on external expansion. As Mao moved to dampen the revolution, Beijing moved to re-establish its foreign policy and improve its links with the outside world.

Both the means and ends of New Zealand's grand strategy changed at the same time. New Zealand and its great power allies abandoned the containment project just as views on China shifted. From the end of the 1960s, New Zealand's Forward Defence efforts ceased to be focused on the containment of China and moved to achieving much more limited goals. New security arrangements were developed to replace the AMDA, ANZAM, and SEATO pacts. The Five Power Defence Arrangements would provide the basis of New Zealand's defence 
commitment to South East Asia with only limited assistance from Britain and without China as a significant threat.

It is in this context that New Zealand made the decision to recognise China. New Zealand Prime Minister Keith Holyoake long maintained the view that the PRC should enter the United Nations and be recognised by New Zealand, provided the position of Taiwan was preserved. Once the effort to keep Taiwan in the UN was lost, New Zealand moved slowly toward recognition. However, it would take the election of the Third Labour Government for recognition to occur. This move was part of an international trend towards official relations with Beijing, but for New Zealand, the shift was greater as Wellington had moved from seeing China as a growing military threat to a state with which New Zealand could have an official dialogue. 
I would firstly like to thank my supervisors Robert Ayson and David Capie. They have shown an immense amount of faith in me. Rob, as my primary supervisor, has been extremely generous with his time and has been endlessly positive, reassuring, and inspiring. I thank them both for the exceptional supervision I have received.

The life of a graduate student is always eased by great administrators. Thankfully, I have had the joy of having Philippa Race, Florence Baggett, and Jonette Crysell assist me through the university processes, as well as be wonderful generally.

I would like to thank the School of History, Philosophy, Political Science and International Relations. I have received significant encouragement from all members of staff, and the school was crucial in obtaining the scholarships I received. I have felt welcome and included amongst members of all the school's staff and students in every discipline.

Gerald Hensley, Chris Elder, and Doug Law all have generously given me their time and provided important firsthand insights into their work in Foreign Affairs. It is their work and the work of their colleagues and predecessors that made this research worth undertaking.

This research would never have been possible without access to files. For this I thank John Crawford and Tony Wilson at NZDF. Their assistance was vital in accessing the newly declassified files which made this thesis what it is. I'd also like to thank Neil Robertson, Jacques Bancilhon, and Demi Kirkpatrick at MFAT for assisting me in obtaining access to their ministry's files. Of course the great work of Archives New Zealand and the National Archives of Australia must also be acknowledged. They always try to make things easier for researchers.

The work of New Zealand's defence historians, in particular Ian McGibbon, Chris Pugsley, Damien Fenton, and Raberto Rabel has been a source of great inspiration and this research would not have been possible without their writings to build from.

I'd like to thank Joe Burton, Jana von Stein, and Wenwen Shen for giving me a stimulating class to tutor. I learnt a huge amount about the art of lecturing International Relations from all three. Equally important were the wonderful students I tutored. Their fresh perspectives and impressive essays made me look forward to every tutorial.

For putting up with me as a flatmate I'd like to thank Alan Stenson, Emily Ashill, Tama Nuttall, Clark Stevenson, Tim Stevens, Nadège Vettard, and Olivia Hodgson. They made Wellington a great place to live. Of course my time in Wellington wouldn't have been half as much fun without Charles Wilson, Louise Kotzé, and Hillary Reid providing incalculable amounts of coffee, chips, good times, and welcome distractions. Other welcome distractions were Lilly, Frances, Missy, and Kima who provided important four-legged company.

Great thanks to Kelly Hicks and Keira Stephenson for their valuable last-minute proof reading.

An all-important thank you to my parents for loving me, feeding me, housing me, and making this thesis possible. For this I owe them everything.

Lastly and most importantly I'd like to thank Kelly Deathe for the endless love she has given me and her sustained and immeasurable patience while I have worked on this project. It is her love and support that has allowed me to complete this work. 


\section{CONTENTS}

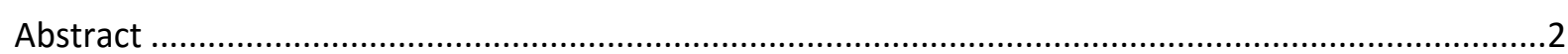

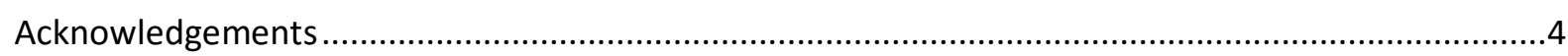

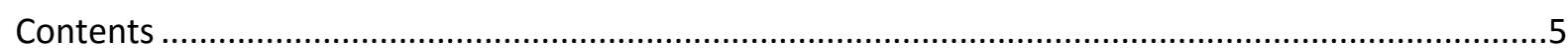

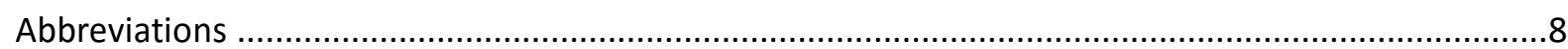

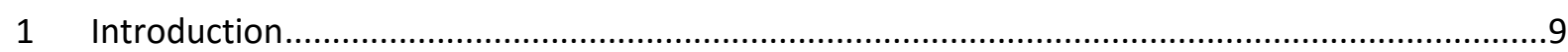

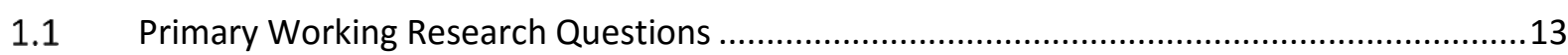

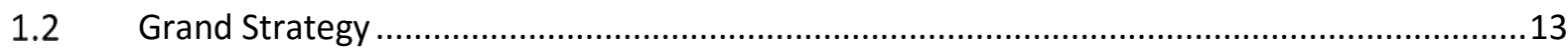

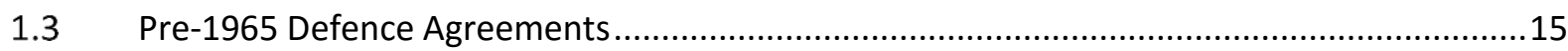

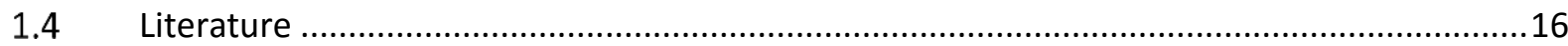

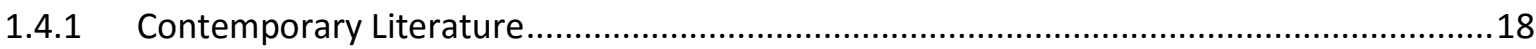

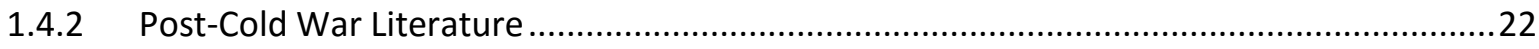

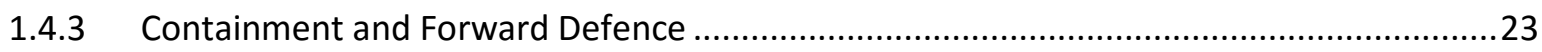

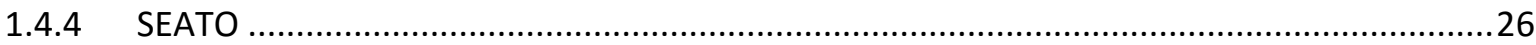

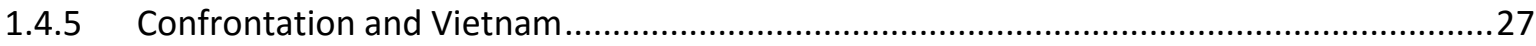

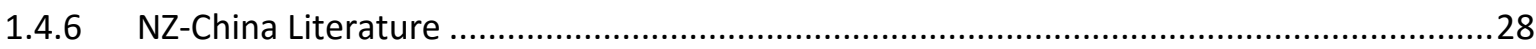

1.4.7 New Zealand and the Great Proletarian Cultural Revolution..........................................32

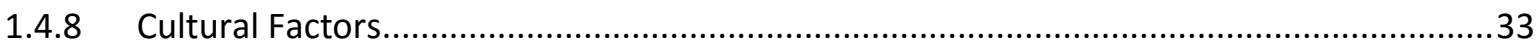

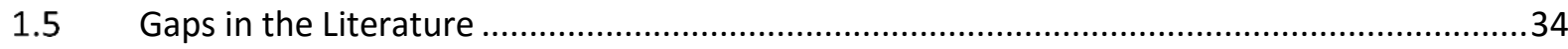

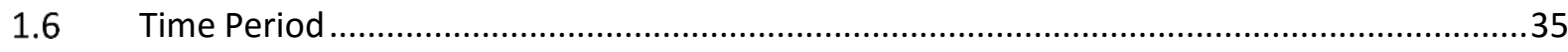

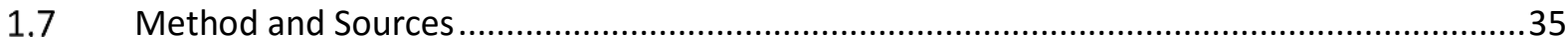

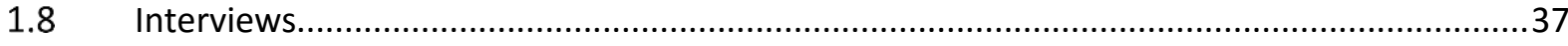

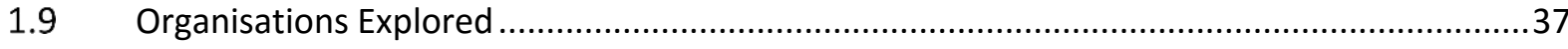

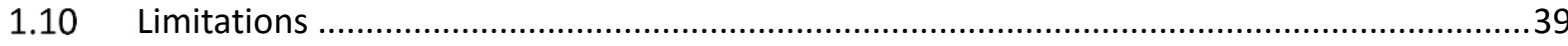

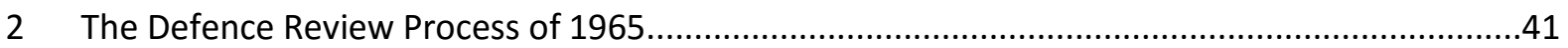

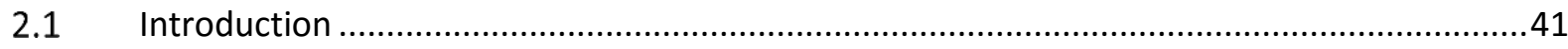

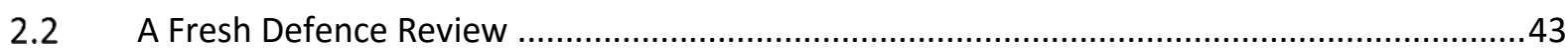

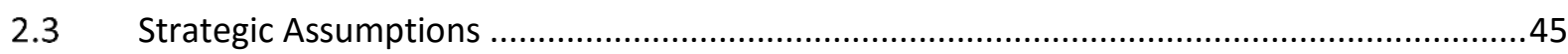

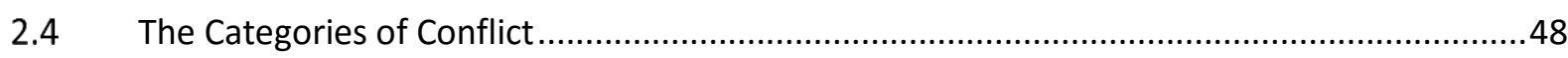

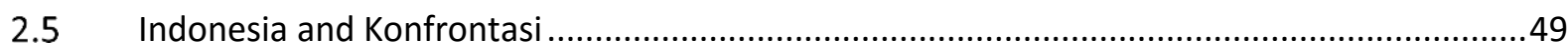

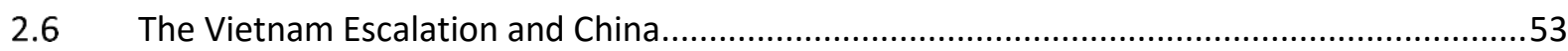

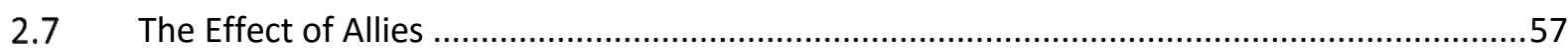

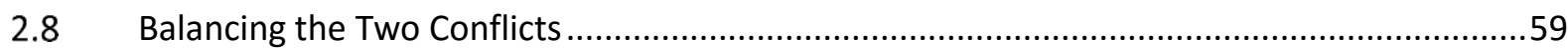

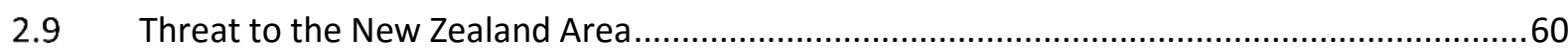

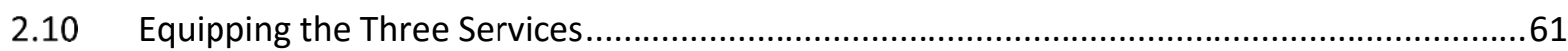

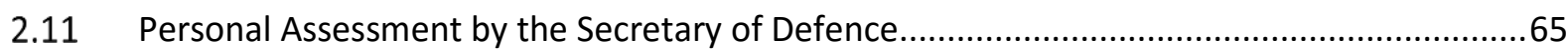

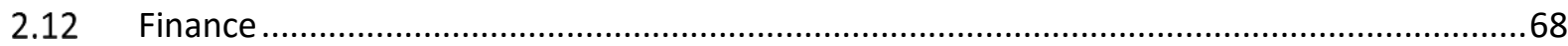

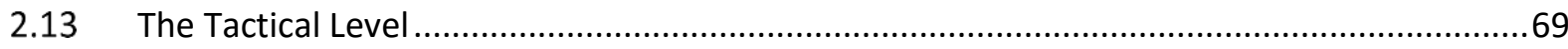

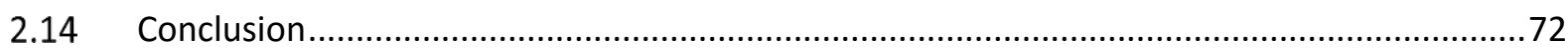


3 Shifting Ends and Means and Perpetual Review

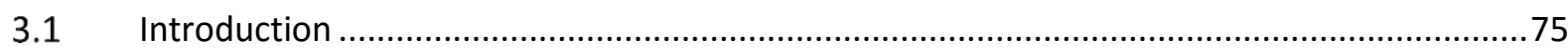

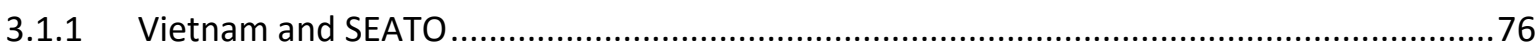

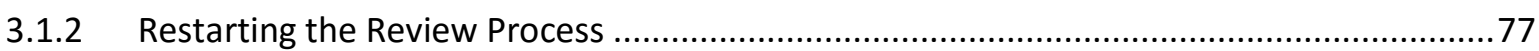

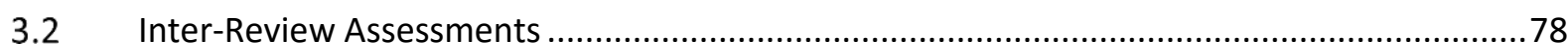

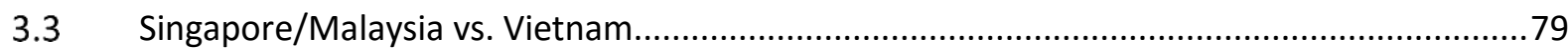

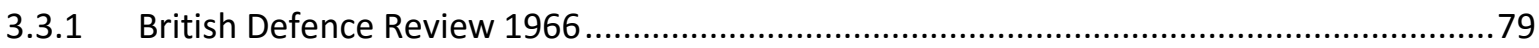

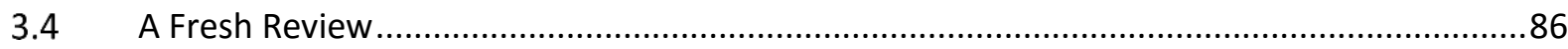

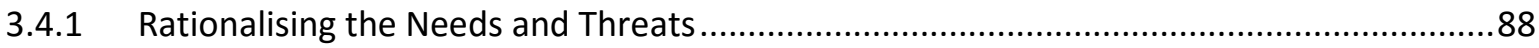

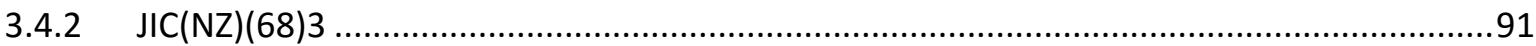

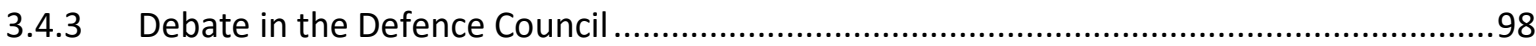

3.4.4 External Affairs and Foreign Policy Goals ......................................................................99

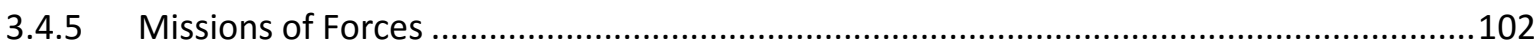

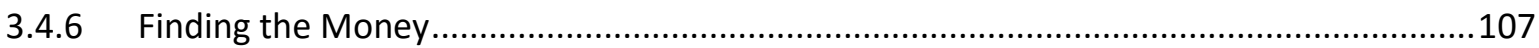

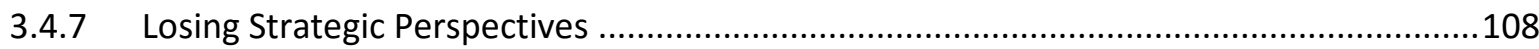

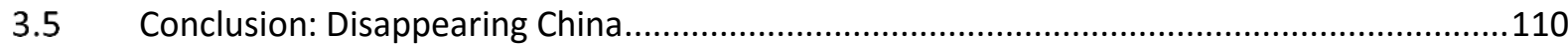

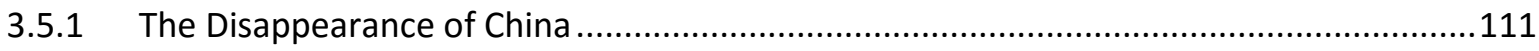

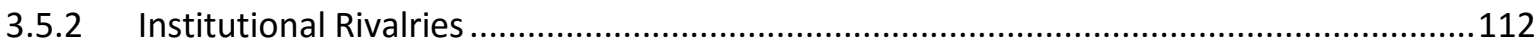

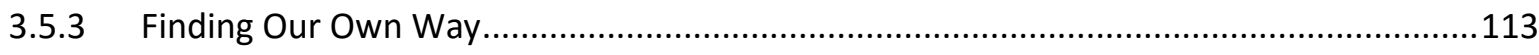

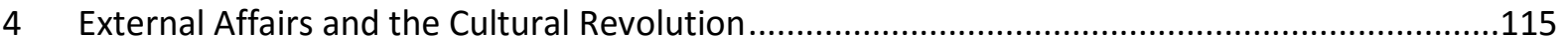

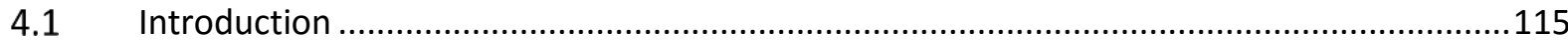

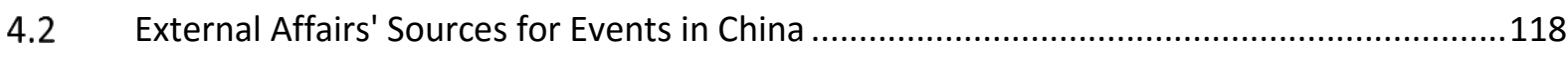

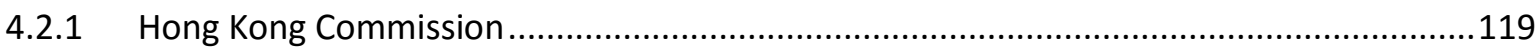

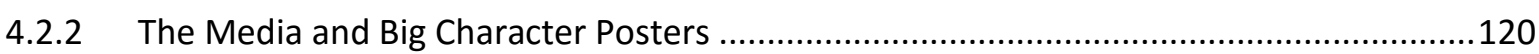

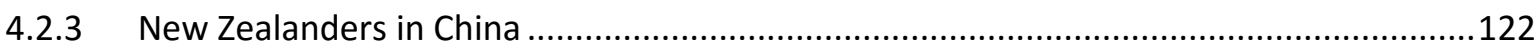

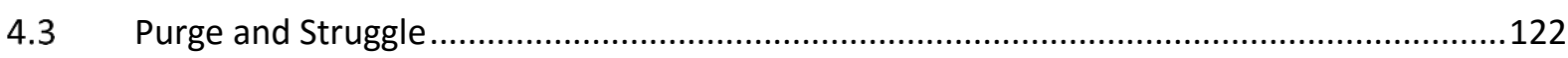

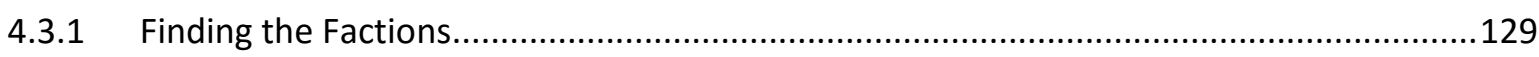

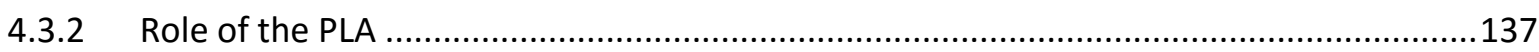

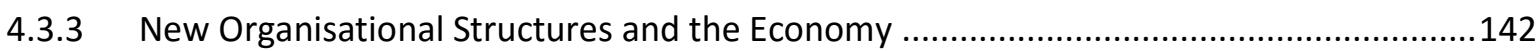

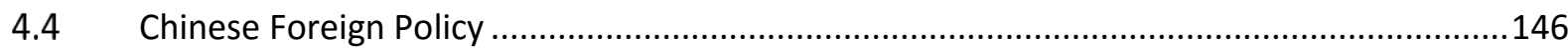

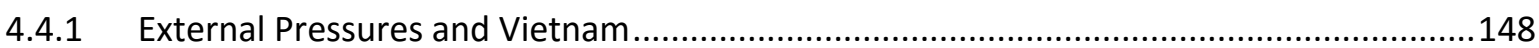

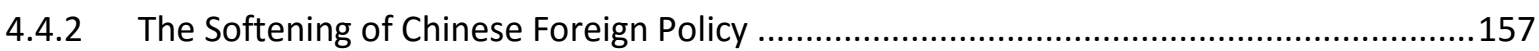

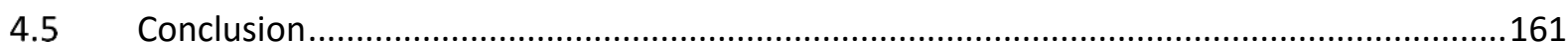

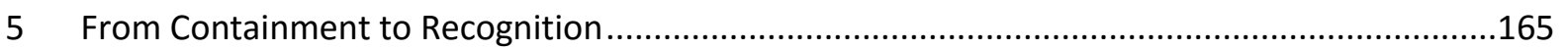

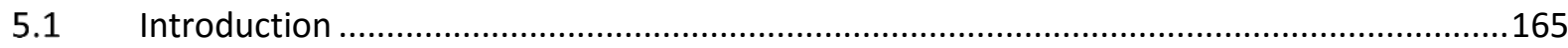

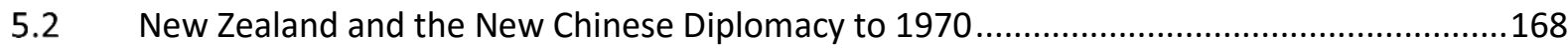

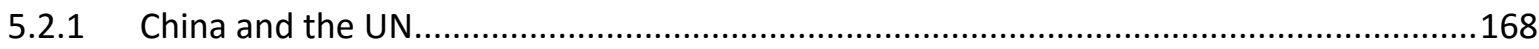

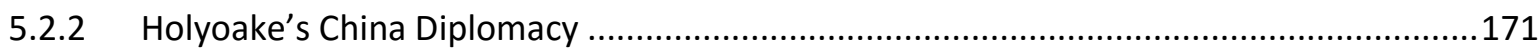

5.2.3 Assessing and Managing the Change in Chinese Foreign Policy .....................................172 
5.2.4 The Nixon Administration Emerges .................................................................. 175

5.3 Defence Policy Responds to Change: 1970-1972 _.....................................................177

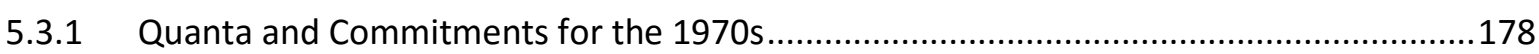

5.3.2 Joint Intelligence Committee Assessment - October 1970...........................................180

5.3.3 The Chiefs Debate the Value of Forward Defence ..................................................... 181

5.3.4 Government Cuts to Defence Spending Growth .................................................. 183

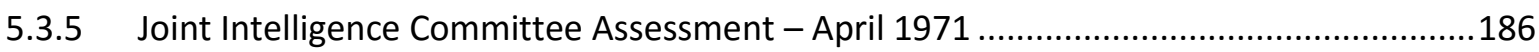

5.3.6 The Five Power Defence Arrangements ............................................................ 188

5.3.7 The Review of Defence Policy 1972 ............................................................. 190

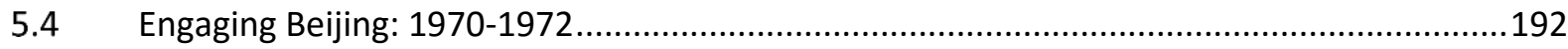

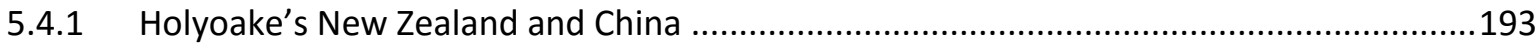

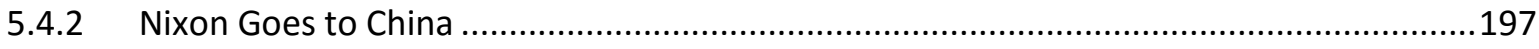

5.4.3 The Commission's View of China's Changing Policy ............................................ 198

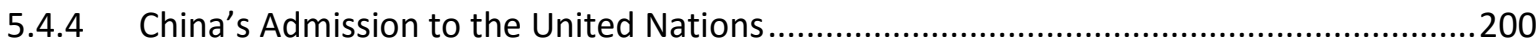

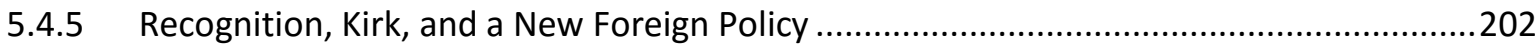

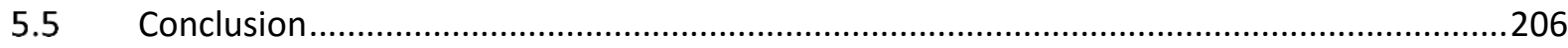

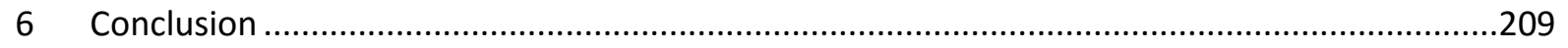

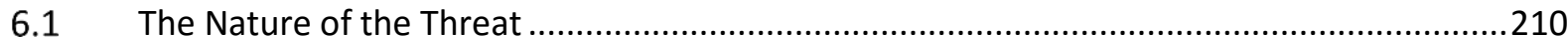

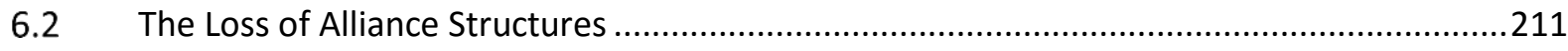

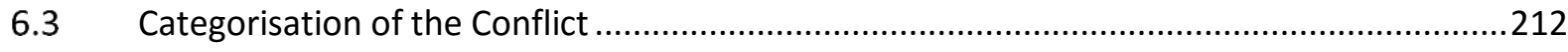

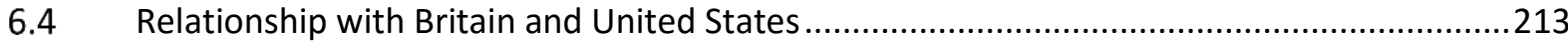

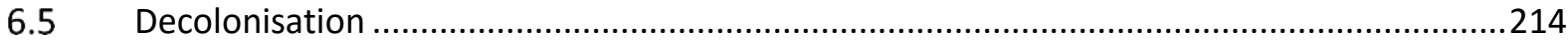

6.6 The NZ Commission in Hong Kong and the Cultural Revolution.....................................214

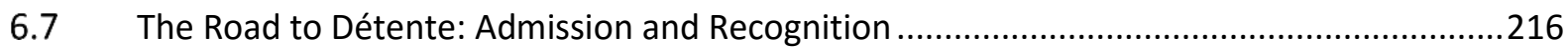

6.8 Limitations of the Research and Future Research Possibilities .......................................218

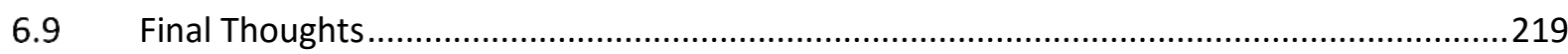

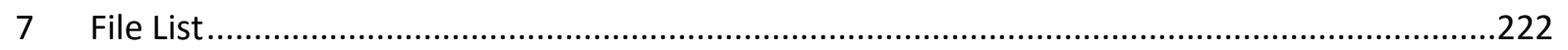

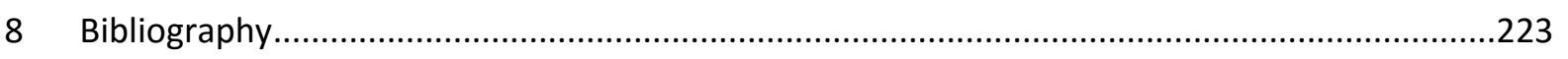

8.1 Newspapers, Magazines, and Unpublished Reports ...................................................223

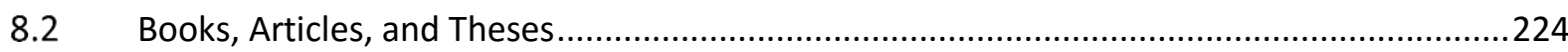




\section{ABBREVIATIONS}

ANZUS Australia New Zealand United States Treaty

ANZAM Australia New Zealand and Malaya

AMDA

Anglo-Malayan Defence Agreement

CAS

Chief of Air Staff

CNS

Chief of Naval Staff

CCP

Chinese Communist Party

$\mathrm{CDC}$

Cabinet Defence Committee

CIA

Central Intelligence Agency

CSR

Commonwealth Strategic Reserve

FPDA Five Power Defence Arrangements

JIC Joint Intelligence Committee

JIC(FE) UK Joint Intelligence Committee (Far East)

JIB Joint Intelligence Bureau

MinDef Minister of Defence

MinEA Minster of External Affairs

NZHC New Zealand High Commission

PRC Peoples Republic of China

RNZAF Royal New Zealand Air Force

RNZN Royal New Zealand Navy

ROC Republic of China

SEATO South East Asian Treaty Organisation (also known as the Manila Pact)

SecDef Secretary of Defence

SecEx Secretary of External Affairs

UK United Kingdom of Great Britain and Northern Ireland

USA United States of America 


\section{INTRODUCTION}

...there is a new note of reality in [New Zealand's] consideration of the Pacific. More and more New Zealanders talk and write as if events in Asia were of serious concern to them and matters on which their country should have a policy - F.L.W. Wood, Pacific Affairs, 22:1, 1949

In the longer term (the 1970s and beyond) the greatest threat to New Zealand's interests and to our own security comes from the growing power of an uncompromising Communist China - Review of Defence Policy 1966, Vol. 1, AJHR, 1966

One of the great events of our lifetime has been the re-emergence of China on the world scene. After a century of weakness and passivity, it has regained strength and begun to exert influence on others. This has changed the complexion of international politics and made the question of relations with China one of the chief issues of the day for governments all over the world. It has special importance for countries like New Zealand that are located in the Pacific area and are, actually or potentially, within the reach of China's power. - Keith Holyoake, New Zealand and China, pamphlet, Ministry of Foreign Affairs, Wellington, 28 May 1971, p. 3

"I don't see any threat from China" - Robert Muldoon, Christchurch Star, 7 May 1976.

New Zealand's foreign and defence policies changed radically between the creation of the Ministry of Defence in 1964 and Norman Kirk's recognition of China in 1972. During this period a number of forces reshaped New Zealand's grand strategy and the assumptions that drove that strategy. Central to this change in strategy was a reshaping of New Zealand's assumptions about the People's Republic of China, the threat that it posed to New Zealand's interests in South East Asia, and the willingness of New Zealand's great power allies to assist in securing those interests. This thesis examines how New Zealand policymakers ${ }^{1}$ and defence officials ${ }^{2}$ assessed China as an international actor between the years 1965 and 1972. This period represents a change from the high water mark of China being viewed as a threat to New Zealand's interests in South East Asia, through to the end of Forward Defence as a

\footnotetext{
1 'Policymakers' in this work describes those at all levels in the policymaking apparatus from civil servants to cabinet-level decision makers. However, the emphasis in this work will be on those providing advice and information to the top levels of bureaucracy and government.

2 'Defence officials' in this work includes civil servants and the top levels of the military such as the Chiefs of Defence Staff.
} 
strategy for the containment of China, and to the view that diplomatic engagement with China best served New Zealand's interests in the region.

From the end of the Second World War New Zealand began to search for new sources of security. ${ }^{3}$ The war demonstrated that Britain and the system of Imperial Defence were no longer reliable and new security arrangements had to be found. ${ }^{4}$ The experience of Japanese aggression in the Pacific, New Zealand's small size, limited industrial capacity, and dependence on Britain, were the driving factors in a rejection of isolationism and a search for security partners. This was pursued initially through commitments to multilateralism, Commonwealth defence, and, later, defence ties with the United States. This strategy came from cultural, economic, and governmental ties that demanded continued access to Britain and its market. With the Communist victory in China, the Cold War moved eastward. The Pacific once again came to dominate New Zealand's security interests as China and communism displaced Japan as New Zealand's primary strategic concerns.

While direct threats to New Zealand would remain low throughout the Cold War, New Zealand joined military alliances such as ANZUS and SEATO, made numerous defence agreements, and fought in conflicts in Korea, ${ }^{5}$ Malaya, ${ }^{6}$ and Vietnam. ${ }^{7}$ Those organisations and conflicts were designed to prevent communist expansion and to contain Communist Chinese power. ${ }^{8}$ The 1950 s saw numerous crises that involved China, not least in the Taiwan Straits ${ }^{9}$ and Indo-China. ${ }^{10}$ With these threats New Zealand developed a strategy of Forward Defence which permanently deployed New Zealand forces to South East Asia in order to help defend Singapore and Malaysia specifically (and South East Asia more generally) from

3 Brook Barrington, 'New Zealand and the search for security 1944-1954: "a modest and moderate collaboration"', PhD Thesis, University of Auckland, 1993

4 Jim Rolfe, 'New Zealand Defence Policy During the Cold War', in Trapeznik and Fox (eds.) Lenin's Legacy Down Under: New Zealand's Cold War, Oxford University Press, Dunedin, 2005, pp. 35-57

5 Ian McGibbon, New Zealand and the Korean War Volume I, OUP and NZ Dept. of Internal Affairs, Auckland, 1992

6 Christopher Pugsley, From Emergency to Confrontation: The New Zealand Armed Forces in Malaya and Borneo 1949-1966, OUP, Auckland, 2003

7 Ian McGibbon's New Zealand's Vietnam War: A History of Combat, Commitment and Controversy, Exisle, Auckland, 2010; Roberto Rabel, New Zealand and the Vietnam War: Politics and Diplomacy, Auckland University Press, Auckland, 2005

8 W. David McIntyre, Background to the ANZUS Pact: Policy-Making, Strategy and Diplomacy, 1945-55, St Martin's \& CUP, Christchurch, 1995, p. 400; Mark Pearson, Paper Tiger: New Zealand's Part in SEATO, 1954-1977, NZIIA, Wellington, 1989, pp. 14-15

9 For New Zealand's files on the first two Taiwan Straits Crises see: EAW2619 163 264/3/2 Vol. 1-6, Individual Countries - China - Political Affairs - Outlying Islands 1954-1956

10 For China's role in the Geneva Conference of 1954 see: Zhai Qiang, 'China and the Geneva Conference of 1954', The China Quarterly, No. 129, March 1992, pp. 103-122 
China and Chinese-inspired communist revolutionary groups. ${ }^{11}$ This policy required the day-to-day support of Australia and the United Kingdom, with the ANZUS alliance providing an ultimate security guarantee from the United States. ${ }^{12}$

The 1960s brought the Sino-Soviet split, Confrontation with Indonesia, the Cultural Revolution, and New Zealand's participation in the Vietnam War. New Zealand viewed these events as a member of Western alliances and through military involvement. Early 1965 saw a period where Wellington officials believed there was a considerable risk of New Zealand being drawn into significant simultaneous conflicts against Indonesia and North Vietnam, with the latter conflict having significant risk of escalating into a limited war with China. ${ }^{13}$

These fears eased quickly, but the systems that provided for New Zealand's interests in South East Asian security would break down over the second half of the 1960s. The British decision to withdraw its forces from South East Asia challenged New Zealand's ability to contribute to the defence of South East Asia and the containment of China. New Zealand and Australia had to ascertain quickly whether their presences in Malaysia and Singapore were viable without British assistance. Facing a military quagmire in Vietnam, the United States sought to limit its own involvement in South East Asia, undermining SEATO and further damaging New Zealand's confidence in the containment of China. While New Zealand's alliance relations continued, the detailed structures that had served Wellington's desire for South East Asia to be defended from China fell apart. New defence arrangements had to be agreed upon if New Zealand was to remain in South East Asia after British withdrawal and peace in Vietnam. However, those new structures would not have the direct involvement of the US or UK and as a result could not be realistically designed to contain China.

As New Zealand's great power partners began to lose interest in military entanglements in South East Asia, China threw itself into the Great Proletarian Cultural Revolution. This revolution would challenge the view among New Zealand officials that China was a growing threat to South East Asia. As China emerged from the Cultural Revolution in

11 Michael Stenson, 'Forward Defence in Asia' in New Zealand in World Affairs Volume 1: 1945-1957, Price Milburn, Wellington, $2^{\text {nd }}$ Edition, 1991, p. 177-199; and Ian McGibbon, 'Forward Defence: The South East Asian Commitment' in Malcolm McKinnon (ed.) New Zealand in World Affairs Volume 2: 1957-1972, NZIIA, Wellington, 1991, pp. 9-40

12 For the formation of ANZUS see: W. David McIntyre, Background to the ANZUS Pact: Policy-Making, Strategy and Diplomacy, 1945-55, St Martin's \& CUP, Christchurch, 1995

13 This is covered in Chapter 2. 
$1969^{14}$ it looked to repair its foreign policy and seek more constructive relations with the outside world. Beijing's ${ }^{15}$ displacement of Taipei from China's seat at the United Nations would be the watershed moment. Beijing's legitimacy in the international community reached a tipping point where significant numbers of countries began establishing relations with Beijing instead of Taipei. Nevertheless, it would take the election of Norman Kirk's Third Labour Government in 1972 for New Zealand to recognise and establish relations with the PRC. By that time, the experience of Vietnam, détente, and generational change was also changing the way New Zealand understood the Cold War.

This research finds that the basis of New Zealand's Forward Defence policy changed radically with the loss of active British and American military support in South East Asia and perceptions of a declining threat from China. This thesis argues that New Zealand's grand strategy was upended by the loss of both the means and ends of its strategic equation. New Zealand lost both the means of helping to contain China and the reasons to do so.

The period from the creation of the Ministry of Defence in 1964 through to the establishment of official relations with Beijing in 1972 represents the most dramatic transition in the history of New Zealand's policies on China. In less than seven years, New Zealand's China policy moved from the PRC being described in the Review of Defence Policy 1966 as the greatest long-term threat to New Zealand's interests and security, to the establishment of official relations. ${ }^{16}$ Just ten years after the Review of Defence Policy 1966 was presented to Parliament, Robert Muldoon met the ailing Mao Zedong and afterwards declared that he saw no threat to New Zealand from China. ${ }^{17}$ The forces that drove this change, the opinions of policymakers, their assumptions, and their assessments on China are the subject of this thesis.

While the literature on New Zealand's search for security and participation in Cold War conflicts is well developed, very little academic attention has been paid to how China was assessed and understood by New Zealand officials. Much of the existing research did not have complete access to documents and there has been little examination of the strategic aspects of New Zealand's assessment of China. Taking an active role in Asia-Pacific

14 The Cultural Revolution is usually considered to span from 1966 to 1976, but this work is most concerned with the early and most violent phase of the revolution which lasted from 1966 to 1968.

15 This thesis uses the modern Pinyin system for transliterating Chinese characters into Roman script. For much of the twentieth century the Wade-Giles method was the standard practice. Chinese words quoted in this thesis have been changed to their modern Pinyin equivalent. Hard brackets indicate the change.

16 Review of Defence Policy 1966, AJHR, A. 8, Vol. 1, 1966

17 Christchurch Star, 7 May 1976 
security required New Zealand to make assessments on global security and the risks posed by China to New Zealand's interests and the interests of its defence partners. This thesis will try to bring together the assessments of New Zealand's diplomatic and military officials to demonstrate how China was understood as an international actor and how it influenced New Zealand's strategic policy. In the $21^{\text {st }}$ century China has arguably become the most powerful state in the Western Pacific. Fresh research on how New Zealand interpreted China in the past will also be timely as it will assist in managing New Zealand's relations with China in the future.

\subsection{PrIMary Working ReSEARCH Questions}

- How did New Zealand policymakers and defence officials assess the People's Republic of China between 1965 and 1972?

- How did China influence New Zealand's grand strategy during this period?

\subsection{Grand Strategy}

Strategy not simply having a policy. A policy is a set of ideas or instructions which attempt to cover a certain issue or problem faced by government. Strategy, especially grand strategy, is much broader. In this sense, strategy is about the meeting of political ends with practical means. ${ }^{18}$ A strategy identifies the ultimate goal of policymakers, identifies the threats to that goal, and brings together the available means to achieve that goal. Yet this definition is incomplete as strategy must be able to adapt. The field of international relations consists of multiple actors in an environment that is continually being reshaped by the interactions between those actors. To be effective in this environment, strategy must be dynamic. That is to say, it must adjust to the moves of other actors, each trying to achieve their own goals and adapt to the situation as it changes. This research attempts to understand New Zealand's foreign and defence policy in this wider context as it attempted to achieve its wider goals with the resources at its disposal.

Strategy as a concept has shifted over time. Coming from the Greek $\sigma \tau \rho \alpha \tau \eta \gamma i ́ \alpha$ (stratēgia) meaning 'art of the general', the word has long been associated with the craft of the general. Many of basic concepts of strategic thought - movement, terrain, espionage, and offensive and defensive manoeuvres - have been written about since antiquity. Sun Tzu's $6^{\text {th }}$ Century

18 Colin S. Gray, Modern Strategy, Oxford University Press, Oxford, 1999, p. 18 
BC work The Art of War $^{19}$ and the ancient Indian political text Arthashastra ${ }^{20}$ detail the challenges of warfighting and remain influential texts today. However, as warfare grew in complexity, the art of the battlefield has become more synonymous with tactics.

Meanwhile, strategy has come to be associated with the use of military to achieve political aims. In the $19^{\text {th }}$ Century, Prussian general Karl von Clausewitz argued that war was a political act. War, is in his words, 'is a mere continuation of policy ${ }^{21}$ by other means'. ${ }^{22}$ Lawrence Freedman has noted that Clausewitz's dictum is not simply a reminder about the interconnection between political and military aims. To Freedman, Clausewitz was also warning about the emotional problems of warfare - 'primordial violence, hatred, and enmity ${ }^{23}$ - and how they might pose a challenge to the rational goals of state. ${ }^{24}$ The lesson being that military objectives are political objectives, but the unpleasant realities of warfare can feedback into the calculations of political leaders.

Clausewitz's Prussian approach to warfare was not universally accepted. Writing between the First and Second World Wars, Basil Liddell Hart advanced an 'indirect method' as an attempt to move away from Clausewitz's ideas on mass armies. ${ }^{25}$ Liddell Hart's naval-based prescription for Britain was at odds with the continentally minded Prussian thinkers like Clausewitz. ${ }^{26}$ Writers like Paul Kennedy have noted that Liddle Hart's strategic vision was one built on his own personal experiences of battle in the First World War and Britain's particular strategic situation. ${ }^{27}$ Regardless of Liddle Hart's particular strategic prescriptions, he provided a clear picture of grand strategy as sitting above the particular needs of a conflict and to the peace that follows. Grand strategy attempts to bring together all the tools of state to achieve a political objective.

...fighting power is but one of the instruments of grand strategy - which should take account of and apply the power of financial pressure, of

19 Sun Tzu, The Art of War, John Minford (translator), Penguin, London, 2002

20 Kautilya (traditionally), Arthashastra, R. Shamasastry (translator), Government Press, Bangalore, 1915 https://en.wikisource.org/wiki/Arthashastra

21 The German word politik can also be translated as 'politics'

22 Carl von Clausewitz, On War, J.J. Graham (translator), Revised by F.N. Maude \& Louise Willmot, Wordsworth Editions, Ware, 1997, p. 22

23 Carl von Clausewitz, On War, Chapter 1, Book 1, 89. As quoted in Lawrence Freedman, Strategy: A History, Oxford University Press, New York, 2013, p. 87

24 Lawrence Freedman, Strategy: A History, Oxford University Press, New York, 2013, pp. 86-87

25 B. H. Liddell Hart, Strategy, $2^{\text {nd }}$ edition, Faber \& Faber, London, 1991.

26 H. Rothfels, 'Clausewitz' in (Edward Mead Earle ed.) Makers of Modern Strategy, Princeton University Press, Princeton, 1971, p. 94

27 Paul Kennedy 'Grand Strategy in War and Peace: Toward a Broader Definition' in Grand Strategy in War and Peace, Paul Kennedy (ed.), Yale University Press, New Haven, 1991, p. 3 
diplomatic pressure, of commercial pressure, and, not least of ethical pressure, to weaken the opponent's will. ${ }^{28}$

It is in this sense that military force (or the threat of military force) is but one tool at the disposal of states in formulating their grand strategies. Grand strategy, therefore, does not necessitate war and can involve the avoidance of it. The practical means available to a state could be utilised to convince an adversary to take another course of action, to maintain an alliance, or to improve relations with another state in order to bring peace. As Edward Mead Earl noted:

\begin{abstract}
Strategy... is not merely a concept of wartime, but is an inherent element of statecraft... In the present-day world, then, strategy is the art of controlling and utilizing the resources of a nation - or a coalition of nations - including its armed forces, to the end that its vital interests shall be effectively promoted and secured against enemies, actual, potential, or merely presumed. The highest type of strategy - sometimes called grand strategy - is that which integrates the policies and armaments of the nation that the resort to war is either rendered unnecessary or is undertaken with the maximum chance of victory. ${ }^{29}$
\end{abstract}

The 'grand' in this sense refers to the overarching nature of this strategy. Grand strategy is defined here as what New Zealand determined to be the relationship between its main foreign policy goals and how it would accomplish those goals. New Zealand may have had strategies in specific areas such as the Vietnam War or its relations with the United States, but 'grand strategy' implies overarching foreign policy goals (ends) and the methods for achieving those goals (means). The only limitation to the use of this definition here is that trade is excluded from the analysis. This is due to that fact trade strategies were not linked to security by New Zealand policymakers during the period being examined. The files of the Ministry of Defence make very few references to trade issues. Expanding exports was a significant goal during this period, but for the purposes of this thesis, grand strategy will be limited to its more traditional space of external defence and security.

\title{
1.3 Pre-1965 Defence Agreements
}

By 1965 New Zealand had already joined a patchwork of defence agreements necessitated by the decline of Britain as a security guarantor during the Second World War. The various and sometimes conflicting pressures caused by these agreements is a major theme of this

28 B. H. Liddell Hart, Strategy, $2^{\text {nd }}$ edition, Faber \& Faber, London, 1991. p. 322

29 Edward Mead Earle, 'Introduction’ in (Edward Mead Earle ed.) Makers of Modern Strategy, Princeton University Press, Princeton, 1971, p. viii 
research. The first such agreement was the 1944 Canberra Pact between New Zealand and Australia. While not a military alliance, it was a pact to work together on issues of mutual interest such as security in the Pacific. After the Second World War, discussions between Britain, Australia, and New Zealand led to the development of Australia-New Zealand-andMalaya (ANZAM). While a vague, informal, and initially secret agreement, ANZAM formed the basis of Commonwealth service-level military planning for the defence of the South East Asia and the South Pacific. ${ }^{30}$

The need for an American security guarantee became a major policy goal after the Second World War. The Australia-New Zealand-United States (ANZUS) Security Treaty of 1951 provided Australia and New Zealand with that guarantee, but meant little in the way of dayto-day military planning with the United States. Planning with the Americans came through the creation of the South East Asian Treaty Organisation (SEATO). Made up of the US, UK, France, New Zealand, Australia, Thailand, Philippines, and Pakistan, it was the main body through which the US planned for the defence of South East Asia. It also provided New Zealand with its closest military links to the United States between the Korean and Vietnam wars.

However, day-to-day operations were still centred around cooperation with Commonwealth allies. From the mid-1950s this was done through the Commonwealth Strategic Reserve (CSR). The CSR attempted to revitalise the ANZAM agreement and give Australia and New Zealand greater responsibility for the defence of Malaya. ${ }^{31}$ This collage of security agreements was not ideal for New Zealand planners, but it did provide a set of commitments by the English speaking powers to defend South East Asia and provided New Zealand with a say in how that defence was conducted.

\subsection{LITERATURE}

The existing research on New Zealand's Cold War focuses on New Zealand's relationship with the Western powers and the conflicts in which New Zealand forces served. The history of New Zealand's foreign policy has been driven by the problems of a small, geographically isolated state seeking to ensure its security and economic viability. Isolation has limited New Zealand's security risks but exacerbated the problems of distant markets and distant

30 W. David McIntyre, 1995, p. 210-222

31 Hiroyuki Umetsu, 'The Origins of the British Commonwealth Strategic Reserve: The UK Proposal to Revitalise ANZAM and the increased Australian Defence Commitment to Malaya', Australian Journal of Politics and History, Vol. 50, No. 4, 2004, pp. 509-525 
protectors. Having a small population and industrial base, New Zealand lacked the power to influence the communist powers and sought to preserve its own security through alliances. New Zealand's strategic focus was directed towards the larger Western powers that provided security, rather than the communist powers who posed the largest threats to Western interests.

It is unsurprising then that the literature has focused on the relationship with those states that have provided either security or a market for our exports. The Second World War saw the end of Britain as a reliable security guarantor and the Cold War saw the emergence of new threats to New Zealand's interests. Events like the establishment of the People's Republic of China and, more importantly, the Korean War $^{32}$ kept the United States engaged in East Asia and allowed New Zealand to obtain a security guarantee from the US. ${ }^{33}$ Managing the US and UK relationship would dominate New Zealand's experience of the early Cold War as those powers provided the support New Zealand's interests required. ${ }^{34}$ The importance of these friendly relationships produced a large body of archival material that researchers were drawn to. Conversely, New Zealand's adversarial relationships have been relatively ignored by scholars. Writing since the end of the Cold War has highlighted the independence of New Zealand's thinking on foreign policy, ${ }^{35}$ yet New Zealand's analysis of China has yet to be truly examined against this perspective. While New Zealand's diplomatic and military establishments were small, this thesis will argue they were able to produce independent analysis on Chinese intentions.

The development of New Zealand's diplomatic apparatus, ${ }^{36}$ the general trends in foreign policy, ${ }^{37}$ the development of alliances, ${ }^{38}$ and the details of New Zealand's military adventures $^{39}$ are well developed in the literature. However, literature that directly focuses on New Zealand's official understanding of China during the Cold War is limited, and is largely

32 Ian McGibbon, New Zealand and the Korean War Volume I, OUP and NZ Dept. of Internal Affairs, Auckland, 1992

33 W. David McIntyre, Background to the ANZUS Pact: Policy-Making, Strategy and Diplomacy, 1945-55, St Martin’s \& CUP, Christchurch, 1995

34 F.L.W. Wood, 'ANZAC Dilemma', International Affairs, Royal Institute of International Affairs, Vol. 29, No. 2, April 1953, pp. 184-192

35 Malcom McKinnon, Independence and Foreign Policy: New Zealand in the World Since 1935, Auckland University Press, Auckland, 1993

36 Sir Alister McIntosh, 'Origins of the Department of External Affairs and Formation of an Independent Foreign Policy, in New Zealand in World Affairs: Volume 1 1945-1957, NZIIA, Wellington, 1977

37 McKinnon, 1993

38 W. David McIntyre, 1995

39 McGibbon, 1992; Christopher Pugsley, From Emergency to Confrontation: The New Zealand Armed Forces in Malaya and Borneo 1949-1966, OUP, Auckland, 2003; Ian McGibbon, New Zealand's Vietnam War: A History of Combat, Commitment and Controversy, Exisle, Auckland, 2010 
in the form of chapters, ${ }^{40}$ articles, ${ }^{41}$ and theses. ${ }^{42}$ Most of the established research concentrates on the debate over official recognition of the Communist Government in Beijing. Since the mid-1980s political and economic changes in both New Zealand and China have prompted a large amount of contemporary and future focused research. ${ }^{43}$ However, these works do not try to assess earlier perspectives.

The cultural and ethnic elements of New Zealand's relationship with Chinese people (especially Chinese-New Zealanders) have been explored in a range of publications. ${ }^{44}$ Notable person-to-person links were built and maintained during the Cold War while New Zealand had no official relations with the Beijing government. These have attracted the attention of some scholars, but this material often lacks an exploration of the New Zealand government's position especially in regards to security policy. The somewhat relaxed attitude of the New Zealand Government to New Zealand communists and sinophiles is puzzling when compared to the grand strategy employed by Wellington during the Cold War. The literature is yet to properly compare these two threads of New Zealand's assessment of China. ${ }^{45}$

\subsubsection{Contemporary Literature}

The general New Zealand foreign policy literature on the period 1949-1972 can be divided between contemporary texts and histories produced since the end of the Cold War. The

40 Anne-Maire Brady, 'The War that Never Was', in Trapeznik and Fox (eds.) Lenin's Legacy Down Under: New Zealand's Cold War, Oxford University Press, Dunedin, 2005, pp. 131-153

41 Anne-Maire Brady, 'New Zealand-China Relations: Common Points and Differences', New Zealand Journal of Asian Studies, Vol. 10, No. 2, 2008, pp. 1-20

42 Daiman Smith, 'Official Attitudes Towards China Between 1945 and 1957: The Development of the NonRecognition Policy', MA Thesis, Massey University, 1997; David McCraw, 'Objectives and Priorities in New Zealand's Foreign Policy in Asia 1949-75: A Study of the Issue of the Recognition of the People's Republic of China and of Security Policies in South-East Asia’ PhD Thesis, University of Otago, Dunedin, 1978; Roy Gordon Shuker, 'New Zealand Policy and Attitudes Toward Communist China', MA Thesis, VUW, Wellington, 1971; Karen Leigh Irvine, 'New Zealand’s Recognition of Communist China', BA (Hons) Dissertation, University of Otago, Dunedin, 1978; Beihua Zhang, Sino-New Zealand Relations 1792-1987, MPhil Thesis, University of Waikato, Hamilton, 1988

43 The starting point for thinking of China as a major trading partner seems to have been during the Fourth Labour Government. For instance: 'Report of the Foreign Affairs and Defence Committee on the inquiry into the New Zealand-China relationship’, New Zealand Parliament. Foreign Affairs and Defence Select Committee, 1986

44 Guy Scholefield and Thomas Hall, Asiatic immigration in New Zealand, Institute of Pacific Relations, Honolulu, 1927; Ng Bickleen Fong, The Chinese in New Zealand: A Study in Assimilation, Hong Kong University Press, Hong Kong, 1959; James Ng, The Chinese in New Zealand: A Bibliography, Dunedin, 1962; Stuart William Greif, The Overseas Chinese in New Zealand, Asia Pacific Press, Singapore, 1974; Ip, Manying, (ed.), The Dragon \& the Taniwha: Māori \& Chinese in New Zealand, AUP, Auckland, 2009; Ip, Manying (ed.), Unfolding History, Evolving Identity: The Chinese in New Zealand, AUP, Auckland, 2003

45 This is with the exception of Brady’s work (2004 \& 2008) which this thesis argues is flawed. See the Conclusion for a detailed discussion. 
contemporary security literature is limited in size and says little about the PRC. Hampered by limited access to official sources, some, like W.T. Roy, questioned the extent to which New Zealand's policy was simply dictated by Washington, London, and Canberra. ${ }^{46}$ The academic community was small and so research output came in waves as new authors emerged. Writers were constrained by a high level of secrecy on the part of the country's diplomatic community. In a 1970 text for high school students Keith Sinclair noted the challenges of detailing New Zealand's policy at the time.

We have little detailed knowledge of New Zealand's role or contributions. Diplomats and politicians are usually secretive, and ours unusually and unnecessarily so. We have no books like those by the Australians Sir Perry Spencer and Sir Alan Watt... ${ }^{47}$

As a result of this secrecy, some of the best writing from this period came from senior officials who understood the debates occurring inside government. ${ }^{48}$ Despite the limitations of the time, good analysis of New Zealand's foreign policy did occur. The edited volume New Zealand in World Affairs Volume $1^{49}$ stands out, as does Richard Kennaway's New Zealand Foreign Policy 1951-1971, ${ }^{50}$ but only the latter provides detailed discussion of New Zealand's attitudes to Communist China. ${ }^{51}$

Even for the best informed, the level of independence a small country could possess in its foreign relations remained an on-going question. Independence can be divided between independence of information, independence of analysis, independence of position, and independence of action. New Zealand's independence of action has always been limited by its size, but its ability to collect information, generate independent analysis, and take independent positions has grown over time and was greater than it may have appeared during the Cold War. New Zealand governments had long formed independent opinions on international affairs and security within the framework of Empire Defence, ${ }^{52}$ but the

46 W. T. Roy, 'New Zealand's China Policies: A Review and a Prospect', in (D. Bing ed.) China: Cultural and Political Perspectives, Longman Paul, Auckland, 1975, pp. 125

47 Keith Sinclair, New Zealand in the World Since 1945, Heinemann Educational, Auckland, 1970, p. 14

48 A.D. McIntosh, 'Administration of an Independent New Zealand Foreign Policy', in (T.C. Larking ed.) New Zealand's External Relations, OUP, Wellington, 1962, pp. 30-61; G. R. Laking and NZIIA, New Zealand and Australia: Foreign Policy in the 1970's, Price Milburn, Wellington, 1970; Bruce Brown, New Zealand Foreign Policy in Retrospect (1947-54 and the 1960s), NZIIA Pamphlets, No. 12, NZIIA, Wellington, 1970; McIntosh, 1977

49 McIntosh, 1977

50 Richard Kennaway, New Zealand Foreign Policy 1951-1971, Hicks Smith, Wellington, 1972

51 Kennaway, 1972, pp. 62-69

52 John Russell Glackin, New Zealand and Imperial Defence: The Development of New Zealand's Strategic Attitudes 1870-1893, MA Thesis, University of Canterbury, 1966 
country's influence on imperial foreign policy was minimal. ${ }^{53}$ Bennett argued that independent positions in foreign policy began in 1935 with the First Labour Government. ${ }^{54}$ However, Templeton has argued that genuine external relations only began after Britain's acknowledgement in 1942 that only the US could defend New Zealand from Japan. ${ }^{55}$

During the Second World War New Zealand sent envoys to Canberra, Ottawa, Washington, and Moscow. These were New Zealand's first official representatives outside of London and the League of Nations and so signified the beginnings of independent representation and sources of information. These representations necessitated a much larger and sophisticated diplomatic apparatus, ${ }^{56}$ specially to engage with the challenges of post-war Asia. ${ }^{57}$

How quickly the sophistication of that apparatus developed was not easily apparent during the early Cold War as governments were sparing in their criticisms of friendly countries. The impetus for independent diplomatic relations was the need for new security guarantees during and after the Second World War, but once these guarantees had been achieved New Zealand's subservience to its allies came into question. Wood ${ }^{58}$ and Gordon ${ }^{59}$ both saw New Zealand policy of the late 1940s as having to take much greater notice of Asia than prior to the war, but assumed any involvement would be limited by New Zealand's size. Wood noted that New Zealand favoured multilateralism but described this as being at least partially due to physical isolation from centres of conflict.

Western security concerns moved eastward with the Communist victory in China, the start of the Korean War, and the emergence of communist insurgencies in South East Asia. These events brought security concerns closer to New Zealand's shores, fostering ANZUS, SEATO, and ANZAM. Such initiatives confirmed New Zealand's support for containing communist expansion while solidifying New Zealand's security guarantee. J.F. Northey considered security to be the main driver of New Zealand foreign policy in the early $1950 \mathrm{~s}$, with Japan still the primary strategic concern. ${ }^{60}$ Gordon $^{61}$, Kennaway, ${ }^{62}$ and later McIntyre ${ }^{63}$

\footnotetext{
53 McIntosh, 1962, p. 31

54 Bruce S. Bennett and NZIIA, New Zealand's Moral Foreign Policy, 1935-1939: The Promotion of Collective Security Through the League of Nations, NZIIA, Wellington, 1988

55 Malcolm Templeton (ed.), An Eye, an Ear and a Voice: 50 Years in New Zealand's External Relations 1943-1993, MFAT, Wellington 1993

56 McIntosh, 1962, p. 32

57 Bernard K. Gordon, New Zealand Becomes a Pacific Power, University of Chicago Press, Chicago, 1960

58 F.L.W. Wood, 'Report From New Zealand', Pacific Affairs, Vol. 22, No. 1, March 1949, pp. 38-40

59 Gordon, 1960, p. 255

60 J.F. Northey, 'Foreign Policy for Australia and New Zealand', International Journal, Vol. 6, No. 3, Summer 1951, pp. 197-206

61 Gordon, 1960
} 
argued that New Zealand and Australia accepted a 'soft peace' with Japan in exchange for a formal defence agreement with the United States. Communism would be opposed but alliances with Asian states were not considered desirable. Enthusiasm for multilateralism and the UN was hedged with commitment to the Western Powers and the containment of communist expansion. ${ }^{64}$

By the early 1950s Wood ${ }^{65}$ and W.F. Monk ${ }^{66}$ were seeing New Zealand policy as having to balance multilateralist values with the need for greater defence commitments. Both Wood and Monk defended the ANZUS pact as part of a struggle to maintain ties with Britain while forging new ones with the United States. New Zealand would be best served by the continuance of the Anglo-American partnership, with Britain's decision to recognise Beijing in early $1950^{67}$ an issue of divergence and a concern. ${ }^{68}$ Monk emphasised New Zealand's fears of communism and a resurgent Japan pushing Wellington into the American camp rather than adhering to a universal approach to security. He made the point that while action in the Middle East could still have been envisioned without US assistance, any action in the Pacific had become unthinkable without American involvement. ${ }^{69}$ American policy toward China was the crucial factor in the maintenance of Pacific security.

It would be hard to say whether the effect of the Anzus Pact has been to decrease or to increase New Zealand's sense of security... In the TwoPower world pattern there is no place for the individual Japanese aggression [sic], in the contemplation of which New Zealanders are still apt to be absorbed. Most criticism, therefore, has tended to be misplaced. Where, before the Anzus Pact, there was strong criticism on general grounds of the MacArthur policies first in Japan and then in Korea, including the crossing of the 38th parallel, subsequently similar criticism of the Yalu bombings and of the Eisenhower de- neutralization policy towards the Chiang Kai-shek regime in Formosa has tended to be linked emotionally with the Pact. All such criticism, in any case, springs fundamentally from the same motive: not so much from dissatisfaction at the supposed commitments and policies associated with the Pact as from frustration at New Zealand's and, indeed, everybody else's helplessness to deflect the policies of a too-powerful friend - a friend without whom it

Kennaway, 1972

McIntyre, 1995

Northey, 1951, p. 200

Wood, 1953

66 W. F. Monk, 'The Impact of Asia: New Zealand Faces North', Pacific Affairs, Vol. 26, No. 3, September 1953, pp. 220-229

67 The UK recognised the PRC on 6 January 1950 and sent a chargé d'affaires to Beijing, but the PRC did not provide reciprocal recognition until 1972.

68 Wood, 1953, p. 192

69 Monk, 1953, p. 222 
would be impossible to get on at all, but alongside whom one might one day find oneself fighting in a last convulsive Armageddon. ${ }^{70}$

With this passage Monk encapsulated the issue of the day. The Cold War had removed the threat of Japanese aggression but China and Soviet Union were now serious challenges in the Pacific. ANZUS had created a new security dilemma for Wellington as it needed American protection but could have little impact on how Washington managed the communist threat. Looking back at the 1950s Gordon saw New Zealand 'totally dependent on the good will of the United States' for its security. ${ }^{71}$

Academic interest in New Zealand security policy was renewed in the 1970s as the Vietnam War broke down the foreign policy consensus of the mid-1950s to the mid-1960s. ${ }^{72}$ The rapid pace of change in international relations during the early 1970s produced an increase in research on foreign and strategic policy in New Zealand. ${ }^{73}$ However, this scholarship would still be hampered by much of the same restrictions as earlier writers. It would not be until after the breakdown of ANZUS, the end of the Cold War, and the opening of archives, that New Zealand's Cold War foreign policy could be fairly assessed in light of access to government documents.

\subsubsection{Post-Cold War Literature}

Armed with better access to documents, more recent accounts have placed stronger emphasis on the ability of New Zealand's diplomatic apparatus to generate independent analysis or at least build this ability during the Cold War period. Malcolm McKinnon's Independence and Foreign Policy explored directly these tensions in New Zealand's international relations. ${ }^{74}$ At the same time, several other texts explored New Zealand's postwar diplomatic and strategic efforts. ${ }^{75}$ These texts provided a depth of detail on foreign

70 Monk, 1953, p. 227

71 Gordon, 1960, p.256

72 McKinnon, 1993, p. 152; Rabel, 2005, p. 284

73 Brown, 1970; Laking, 1970; Ken Keith \& NZIIA, Defence Perspectives: Papers Read at the 1972 Otago Foreign Policy School and Edited by Ken Keith, Price Milburn, Wellington, 1972; Kennaway 1972; Dov Bing (ed.), China: Cultural and Political Perspectives: a Selection of Papers Presented at the First New Zealand International Conference on Chinese Studies, University of Waikato, 1972, Longman Paul, Auckland, 1975; Erik Olsen \& W. Webb (ed.) 'New Zealand Foreign Policy and Defence', Proceedings from the $12^{\text {th }}$ New Zealand Foreign Policy School, University of Otago, Dunedin, 1977; John Henderson, Beyond New Zealand : the Foreign Policy of a Small State, Methuen, Auckland, 1980

74 McKinnon, 1993

75 Roberto Rabel, 'New Zealand and the United States in the Early Cold War Era, 1945-49', Australasian Journal of American Studies, Vol. 7, 1988, pp. 1-10; Pearson, 1989; McKinnon, 1991; McGibbon, 1992; Templeton, 1993; Barrington, 1993; Ann Trotter (ed.), New Zealand and China: The Papers of the TwentyFirst Foreign Policy School 1986, Foreign Policy School Series, University of Otago, Dunedin, 1986; 
policy that had been previously unavailable and showed the strength of the analysis generated by New Zealand officials. Unsurprisingly, research has focused on the pressures of the alliance relationships or war-fighting as these were the major elements of New Zealand's Cold War experience. This trend has continued into the $21^{\text {st }}$ century. ${ }^{76}$ Perspectives on China are largely absent from these texts, although works on cultural and people-to-people elements have been produced in recent years and have provided some extra context. ${ }^{77}$

Post-Cold War authors began to see the early Cold War period as the 'Search for Security'. ${ }^{78}$ In the second half of the 1940s New Zealand remained committed to the concept of Commonwealth defence backed with collective security. ${ }^{79} \mathrm{~W}$. David McIntyre's Background to the Anzus Pact devoted a chapter to New Zealand's strategic planning in the immediate post-war period. ${ }^{80}$ The book not only explored the diplomatic exchanges, it also sought to understand the strategies and uncertainties of New Zealand and Australia during the formation of the pact. Ian McGibbon's New Zealand and the Korean War Volume I is similar in this regard ${ }^{81}$ Like McIntyre, McGibbon brought together the diplomatic, strategic, and domestic political elements of New Zealand's involvement in the Korean War, and this thesis tries to do the same with respect to China policy.

\subsubsection{Containment and Forward Defence}

Shared with Australia, Forward Defence was a strategy to permanently forward deploy forces in order to defend the air and sea approaches to Australia and New Zealand. Forward Defence put forces in the most unstable but still friendly parts of the region to defend those parts from communist and anti-Western forces, be they state or non-state based threats.

McIntyre, 1995; Damien Marc Fenton \& CSS, A False Sense of Security: The Force Structure of the New Zealand Army 1946-1978, Occasional Paper No. 1, CSS, Victoria University of Wellington, Wellington, 1998

76 Malcolm, Templeton, Standing Upright Here: New Zealand in the Nuclear Age 1945-1990, VUP \& NZIIA, Wellington, 2006; Rabel, 2005; McGibbon 2010; Damien Fenton, To Cage the Red Dragon, SEATO and the Defense of South East Asia 1955-1965, National University of Singapore Press, Singapore, 2012

77 Ip, 2003 \& 2009; Brady, 2004 \& 2008; Ferrall, Millar, and Smith (eds.), East By South: China in the Australasian Imagination, VUP, Wellington, 2005; Chris Elder (ed.), Forty Years On: New Zealand-China relations then, now and in the years to come, VUP, Wellington, 2013

78 Anthony Murdoch et. al., New Zealand's Search for Security, 1945-1985, Longman Paul, Auckland, 1986; Melanie Brewis, Search for Security in the Nuclear Age, 1945 to the Present, History Workbook, Heinemann Education, Auckland 1992; Barrington 1993

79 McIntyre 1995, p. 192

80 W. David McIntyre, Background to the Anzus Pact, Cambridge Commonwealth Series, Canterbury University Press, Christchurch, 1995

81 Ian McGibbon, New Zealand and the Korean War Volume I, University Press in association with the Historical Branch, Dept. of Internal Affairs, Auckland, 1992 
Damon Bristow has argued - without mentioning China - that it was the threat posed by Indonesia to its neighbours that brought about Forward Defence and later the Five Power Defence Arrangements. ${ }^{82}$ But as we will see for New Zealand planners in 1965, Communist China presented the biggest long term threat to the security of South East Asia, with Indonesia determined to be a shorter-term problem.

The Forward Defence strategy was to a large extent based on the experience of Japan's rapid domination of South East Asia. ${ }^{83}$ Writing in 1977 Michael Stenson saw Forward Defence as a strategy that had long roots in Imperial Defence and racial fears of New Zealand being overrun by alien peoples from Asia which almost manifested itself in 1942:

The Japanese advance to the very borders of Australasia in 1942 played out a recurrent nightmare - the irresistible move south of land hungry Asian hordes. ${ }^{84}$

In Stenson's view Forward Defence was part of a longer project in containment, one that predated Communist China. Prior to the 1950s the 'containment' was based on racial fears and after the Second World War those fears became more ideological. As Stenson points out, these kinds of fears were more on the right of the political spectrum whereas, for those on the left, defence lay in collective security arrangements. ${ }^{85}$ Left-wing views saw Western-led containment-based arrangements as a second-best substitute made necessary by the deadlock in the UN. Stenson argued that, regardless of ideological differences, ignorance of Asia hampered New Zealand thinking on security problems on both sides of the parliamentary aisle during the post-war period. ${ }^{86}$

During the 1950s, Forward Defence was part of a wider Commonwealth defence effort to protect the British colonial possessions of Malaya, Singapore, Sarawak, Sabah, and Brunei. Communist insurgency was a significant threat in the 1950s with the mainly ethnic-Chinese Malayan Races Liberation Army fighting a significant guerrilla war which lasted until $1960{ }^{87}$ With the beginnings of independence in 1957 and the formation of Malaysia in

82 Damon Bristow, 'The Five Power Defence Arrangements: Southeast Asia's Unknown Regional Security Organization', Contemporary Southeast Asia: A Journal of International and Strategic Affairs, Volume 27, Number 1, April 2005, pp. 1-20

83 Ian McGibbon, 'Forward Defence: The South East Asian Commitment' in Malcolm McKinnon (ed.) New Zealand in World Affairs Volume 2: 1957-1972, NZIIA, Wellington, 1991, p.12; Michael Stenson, 'Forward Defence in Asia' in New Zealand in World Affairs Volume 1: 1945-1957, Price Milburn, Wellington, $2^{\text {nd }}$ Edition, 1991, p. 192

84 Michael Stenson, p. 180

85 Michael Stenson, p. 183

86 Michael Stenson, p. 185-6

87 See Pugsley, 2003 
1963, the policy shifted to supporting these new states so that they could eventually defend themselves from China and communist insurgencies. This goal became more pressing as the UK announced its plans to withdraw from the region in 1966. British withdrawal from the region challenged New Zealand and Australia's ability to maintain their Forward Defence policies as British bases in Malaysia and Singapore provided the crucial platform for the containment of China.

As noted in the chapters below, the concept of Forward Defence shifted over time. As the threat from China began to wane in the late 1960s, the role of New Zealand forces changed again. The goal of Forward Defence became less about holding back China and more about helping Malaysia and Singapore enhance their own security with benefits in training and development for New Zealand forces. Ultimately, the goal was the creation of friendly, stable, buffer states between China and Australasia. ${ }^{88}$

This thesis argues that Forward Defence was a regional level implementation of George Kennan's policy of containment. Kennan became influential during the Truman Administration and his writing became the basis of the American strategy of containment. ${ }^{89}$ Kennan's ideas were broadened with the policy statement NSC- $68^{90}$ which became the basis of American policy towards the Communist powers until the Nixon Administration. ${ }^{91}$ Containment aimed to maintain a balance of power which would halt Soviet and Chinese expansion while not attempting to 'roll back' communist gains in Europe.

For New Zealand, Forward Defence was based on the same principles articulated by Kennan. Chinese power needed to be stopped from spreading further into South East Asia and thus potentially threatening Australia. This strategy required the assistance of great powers, as New Zealand and Australia could not provide the military effort required to contain China. The maintenance of active alliances was crucial to the project. SEATO provided the link to the Americans, but it was the British that provided the logistics, administration, bases, and that ensured the Australasian presence. Keeping the British and

88 McGibbon, 1991, p. 13

89 Kennan wrote a US State Department memo which became known as 'The Long Telegram' http://www.trumanlibrary.org/whistlestop/study_collections/coldwar/documents/pdf/6-6.pdf; this became the basis of an article that was initially published under the pseudonym X, George F. Kennan, 'The Sources of Soviet Conduct,' Foreign Affairs, July 1947, https://en.wikisource.org/wiki/The_Sources_of Soviet_Conduct

90 'NSC 68: United States Objectives and Programs for National Security', US National Security Council, 14 April 1950, http://fas.org/irp/offdocs/nsc-hst/nsc-68.htm

91 See John Lewis Gaddis, Strategies of Containment: A Critical Appraisal of American National Security Policy During the Cold War, Revised and Expanded Edition, OUP, New York, 2005 
Americans involved in the region was therefore a major goal of New Zealand defence policy.

\subsubsection{SEATO}

There have been surprisingly few studies of the South East Asian Treaty Organisation. SEATO represented New Zealand's biggest connection to American military planning for South East Asia as ANZUS provided little in the way of military coordination. The Manila Pact, as it was also known, was designed to contain Chinese expansion in South East Asia. ${ }^{92}$ SEATO created a number of war plans that involved New Zealand. The largest was Plan 4 which was designed to repel a significant Chinese invasion of South East Asia. ${ }^{93}$ Having only one member on the Asian mainland (Thailand) was problematic in an era of decolonisation, especially as the treaty also aimed to protect the non-member 'protocol states' of Laos and South Vietnam. By the mid-1960s France and Pakistan had effectively left the organisation and it slowly faded from relevance as the US acted outside the treaty in its pursuit of the Vietnam War.

Leszek Buszynski's 1983 SEATO: The Failure of an Alliance Strategy, was highly critical of SEATO and points to its failure to address Vietnam which led the US to act outside the bounds of the treaty in its conduct of the war. ${ }^{94}$ Mark Pearson's analysis of New Zealand's involvement in SEATO, Paper Tiger, outlined many of the diplomatic exchanges and organisational issues within SEATO, but spent little time on the threat perceptions that precipitated its creation. The chapter titled 'Meeting the Threat (1) New Zealand's Part in SEATO Strategies' devoted many of its pages to questions of economic assistance but only a few to plans for counter-insurgency and scenarios for region-wide conflict with North Vietnam or China. Pearson noted that New Zealand was not in a strong position to criticise the US defence planners nor was it privy to nuclear targeting information. ${ }^{95}$ Damien Fenton's To Cage the Red Dragon was less critical of the alliance. Fenton described the significant disagreements between the alliance members over the formation of the war plans, especially Plan $4 .^{96}$

\footnotetext{
92 Mark Pearson, Paper Tiger: New Zealand's Part in SEATO, 1954-1977, New Zealand Institute of International Affairs, Wellington, 1989

93 Damien Fenton, To Cage the Red Dragon, SEATO and the Defense of South East Asia 1955-1965, National University of Singapore Press, Singapore, 2012

94 Leszek Buszynski, SEATO, the Failure of an Alliance Strategy, Singapore University Press, Singapore, 1983

95 Pearson, 1989, p. 63

96 Fenton, 2012
} 


\subsubsection{Confrontation and Vietnam}

Confrontation with Indonesia has received relatively little examination from New Zealand scholars. Sukarno's opposition to the creation of Malaysia led to a policy of Konfrontasi or Confrontation from 1963. What resulted was three-and-a-half years of quasi-war where the Indonesian army initiated a series of skirmishes and raids with Commonwealth forces in Borneo. The conflict ended with Sukarno's replacement by Suharto in an anti-communist coup in September 1965 and this eventually led to the end of Confrontation the following year. Christopher Pugsley's From Emergency to Confrontation tracked the history of New Zealand's involvement in Malaysia from the start of the Malayan Emergency to the end of Confrontation. Its focus was squarely on the detail of the conflict on the ground. ${ }^{97}$ John Subritzky's Confronting Sukarno covered the diplomacy between New Zealand, Australia, the UK, and the US during the Confrontation. ${ }^{98}$ It covered New Zealand's views and positions well. Subritzky noted Holyoake's unwillingness to spend heavily on defence and reluctance to commit significant forces to Asian conflicts, despite pressure from New Zealand's larger allies to do both. ${ }^{99} \mathrm{He}$ also noted that China was the primary security concern of New Zealand officials in $1965 .{ }^{100}$

Two extensive studies on New Zealand's role in the Vietnam War have been released in recent years. Roberto Rabel's New Zealand and the Vietnam War: Politics and Diplomacy ${ }^{101}$ and Ian McGibbon's New Zealand's Vietnam War: A History of Combat, Commitment and Controversy are good companions as they each look at different aspects of New Zealand's involvement in the conflict. ${ }^{102}$ McGibbon's book details the operational and tactical aspects of the conflict and writes on the experience of soldiers on the ground. Rabel meanwhile explored the diplomatic and domestic politics of New Zealand's involvement. These two books are exhaustive in their detail but also reflect the sharp separation between diplomacy and defence in the scholarly literature.

7 Pugsley, 2003

98 John Subritzky, Confronting Sukarno: British, American, Australian, and New Zealand Diplomacy in the Malaysian-Indonesian Confrontation 1961-5, St Martin’s Press, London, 2000

99 Subritzky, 2000, p. 140

100 Subritzky, 2000, p. 154

101 Rabel, 2005

102 Ian McGibbon's New Zealand's Vietnam War: A History of Combat, Commitment and Controversy, Exisle, Auckland, 2010 
While Rabel made the point that New Zealand's involvement in Vietnam was in part due to the need for American support for the containment of China, ${ }^{103}$ this argument was made more strongly in David Dickens' 1995 thesis on official advice to government on the Vietnam War. ${ }^{104}$ While Dickens' work was focused on Vietnam, it does attempt to look at how the war fitted with New Zealand's wider strategic goals during the period. Nevertheless, one of the issues with the existing research is that it looks at New Zealand's military experience in South East Asia in isolation. Rabel, ${ }^{105}$ Dickens, ${ }^{106}$ McGibbon $^{107}$ and Pugsley ${ }^{108}$ have all provided detailed examinations of New Zealand's involvement in Confrontation and Vietnam but their focus on individual conflicts washes out New Zealand's overarching strategy during the late 1960s and early 1970s.

Barry Gustafson's biography of Keith Holyoake, Kiwi Keith, provides several useful chapters on the prime minister's involvement in Forward Defence, Vietnam, and China. Importantly it provides a good detail on Holyoake's attitude and approaches towards these problems. It argued Holyoake's distrust of the vested interests of the military was a reason for his reluctance to fully fund the programmes developed by the defence establishment. ${ }^{109}$ It also goes into some detail about Holyoake's reluctance to have New Zealand involved in Confrontation and then Vietnam. ${ }^{110}$ The prime minister's two-China policy and unsuccessful efforts at diplomatic engagement with Beijing also receive considerable attention. ${ }^{111}$

\subsubsection{NZ-China Literature}

The shift to more nuanced perspectives due to new information is reflected in some of the more recent literature on New Zealand's China policy. New Zealand's lack of official relations with Beijing between 1949 and 1972 provided little publicly available data for contemporary researchers to work from. During these years Wellington recognised the Nationalist Government in Taipei as the legitimate rulers of China rather than the Communists in Beijing. The question of whether to recognise and establish relations with the PRC dominated New Zealand's policy debate on China and is reflected in the little direct

\footnotetext{
103 Rabel, 2005, p. 348

104 David Dickens, 'New Zealand and the Vietnam War Official Policy Advice to the Government 1960-1972', PhD Thesis, Victoria University of Wellington, 1995

105 Rabel, 2005

106 Dickens, 1995

107 McGibbon, 2010

108 Pugsley, 2003

109 Gustafson, 2007, p. 212

110 Gustafson, 2007, Chapters 11-13

111 Gustafson, 2007, Chapter 14
} 
literature available. The establishment of diplomatic relations is an area where New Zealand was able to act independently, although the level of consideration given to the views of allies is debated. Moreover, the existing research fails to place the debate in a strategic context or compare it with PRC recognition debates of other states.

The direct academic scholarship on New Zealand's Cold War relationships with the communist powers is largely made up of three books. Trapeznik and Fox's Lenin's Legacy Down Under ${ }^{112}$ provided Brady's chapter on China, but mostly focused its attention on the Soviet Union. ${ }^{113}$ Seeing Red, edited by Ian McGibbon and John Crawford, took a broad perspective on New Zealand's Cold War, but did not include a chapter on China. ${ }^{114}$ Work on New Zealand's Cold War policy toward the PRC is largely represented by a small number of theses, ${ }^{115}$ book chapters, ${ }^{116}$ articles, ${ }^{117}$ and conference papers. ${ }^{118}$

Several authors have explored the recognition question, but the issue has never been explored in a substantial published volume. The earliest work comes from a 1971 Master's thesis by Roy Gordon Shuker ${ }^{119}$ and a PhD by David John McCraw in 1978. ${ }^{120}$ McCraw and Shuker worked primarily from press statements, speeches and Parliamentary documents, and appear to have had little-to-no access to government files. For these writers the creation of relations with Beijing was still a live issue. Similarly, Richard Kennaway discussed relations with China in a chapter in his book New Zealand Foreign Policy, published after Richard Nixon's Beijing visit but before the incoming Third Labour Government's decision to establish relations at the end of that year. ${ }^{121}$ In 1988 Beihua Zhang produced a master's thesis that covered New Zealand-Chinese relations from 1792-1988, but again without much access to official records. ${ }^{122}$

By 1997 many of the files from the 1950s which dealt with recognition of Beijing from the Department of External Affairs had been declassified. Taking advantage of this resource, Daiman Smith wrote a master's thesis examining non-recognition by the First Labour and

112 Trapeznik \& Fox, 2004

113 See also: A.C. Wilson, New Zealand and the Soviet Union 1950-1991: A Brittle Relationship, Victoria University Press, Wellington, 2004

114 Ian McGibbon \& John Crawford, Seeing Red: New Zealand, the Commonwealth and the Cold War 194591, NZ Military History Committee, Wellington, 2012

115 Shuker, 1971; McCraw, 1978; Irvine, 1978; Zhang, 1988; Smith, 1997

116 Kennaway, 1972, Walker \& Henderson, 1980, Brady, 2004

117 Brady, 2008

118 Roy, 1975

119 Shuker, 1971

120 David John McCraw, PhD 1978

${ }^{121}$ Kennaway, 1972, pp. 62-69

122 Zhang, 1988 
First National Governments. ${ }^{123}$ Smith's thesis is the most detailed and well-resourced examination of New Zealand's non-recognition policy. However, his work only examines the period to 1957 and is light on the strategic elements of New Zealand's China policy. Unfortunately, a detailed description of Kirk's decision to recognise and establish relations with the PRC is still difficult, as much of the file material is still restricted. Former diplomat Gerald Hensley provides some detail in his memoir Final Approaches, ${ }^{124}$ as does David Grant's biography of Kirk, The Mighty Totara. ${ }^{125}$

To a large extent the issue of recognition has been treated separately to the question of Beijing's admission to the United Nations. One exception is John Scott's chapter 'Recognising China' which focuses on Beijing's UN admission. ${ }^{126}$ It is written from his perspective as a participant in New Zealand's UN delegation at the time of Beijing's admission. Writers focusing on other topics ${ }^{127}$ have mentioned the issue but China's UN representation has been largely ignored by New Zealand authors. However, the recognition and UN admission of Beijing were significant issues for Keith Holyoake. In May 1971 the prime minister published a pamphlet, New Zealand and China, where he advocated a policy of recognising both Beijing and Taiwan. ${ }^{128}$

Shuker, Smith, Kennaway, McGibbon, and Zhang all saw New Zealand as having a largely negative view of China's Communist Government during the Cold War. However, in her book chapter ${ }^{129}$ and in an article, ${ }^{130}$ Anne-Marie Brady has argued that New Zealand's Cold War with China was 'The War that Never Was'. In Brady's view New Zealand's perspective on China was largely friendly and non-recognition was purely a function of New Zealand's alliance with the US. ${ }^{131}$ While this argument is unconvincing in the context of New Zealand's strategic policy, Brady examined elements of New Zealand's perspective that other authors have failed to explore and noted in some detail that Wellington's response to communism was not as severe as that of Australia or the United States.

\footnotetext{
123 Daiman Smith, 1997

124 Gerald Hensley, Final Approaches: A Memoir, Auckland University Press, Auckland, 2006

125 David Grant. The Mighty Totara: The Life and Times of Norman Kirk, Random House, Auckland, 2014

126 John Scott, 'Recognising China' in Malcolm McKinnon (ed.), New Zealand in World Affairs Volume II 1957-1972, NZIIA, Wellington, 1991. pp. 257-253

127 For example: McGibbon, 1992, pp. 102-109

128 Keith Holyoake, 'New Zealand and China', pamphlet, Ministry of Foreign Affairs, Wellington, 28 May 1971

129 Brady, 2004

130 Brady, 2008

131 Brady, 2004, pp. 149-150
} 
While other authors have examined the experience of Chinese in New Zealand prior to the Second World War, Brady sought to explore New Zealand's position based on the experiences of influential New Zealanders in China such as Rewi Alley. ${ }^{132}$ She argued that while New Zealand long had policies restricting Chinese emigration to New Zealand, the relaxed attitude of various New Zealand Governments to person-to-person contacts shows that Wellington did not perceive the PRC as hostile during the Cold War period. ${ }^{133}$ This research demonstrates that Brady's conclusion does not hold when examined against defence policy. Nevertheless, Brady provided a distinct data set providing an important counter-narrative about New Zealand's internal security during the Cold War.

More recent explorations of New Zealand's understanding of China have linked the cultural elements with the diplomatic, such as Chris Elder's edited volumes New Zealand's China Experience $^{134}$ and Forty Years On. ${ }^{135}$ The former book is a wide collection of material covering cultural, economic, and political ties with China, but does not include a section on the years immediately preceding recognition or the strategic element of New Zealand's experience of China in that time period. Forty Years On examines Sino-New Zealand relations since recognition but not before.

As a whole, the literature on New Zealand's China policy during the Cold War is notable for the narrowness of its treatment of the subject, as recognition dominates the literature. However, no author has compared New Zealand's debates on recognition with those in other Western countries, with the exception of Britain which chose to recognise Beijing soon after Mao's victory. Several have pointed out the British decision to recognise China was influenced by its significant investments in China and the need to defend the status of Hong Kong. ${ }^{136}$ There is literature on the processes taken towards the recognition of the PRC by Australia, ${ }^{137}$ Canada, ${ }^{138}$ India, ${ }^{139}$ the United Kingdom ${ }^{140}$ and the United States, ${ }^{141}$ but these

132 See also: Anne-Maire Brady, Friend of China - The Myth of Rewi Alley, RoutledgeCurzon, London, 2003

133 Brady, 2004, pp. 149-150

134 Chris Elder (ed.), New Zealand's China Experience: Its Genesis, Triumphs, and Occasional Moments of Less than Complete Success 1947-2012, VUP, Wellington, 2014

135 Elder (ed.), 2013

136 McKinnon 1993, p. 118

137 Edmund S. K. Fung and Griffith University, Australia's Policy Towards the People's Republic of China, 1966 to 1969, Research Paper, Centre for the Study of Australian-Asian Relations, Griffith University, no. 3, 1980; David Lee and Stuart Doran, Australia's Recognition of the People's Republic of China, Australian Government - DFAT, 2002; Joel Atkinson, 'Australian Support for an Independent Taiwan Prior to the Recognition of the People's Republic of China', Australian Journal of Politics \& History, Vol. 57, 2011, pp. 68-85

138 Paul M. Evans and B. Michael Frolic, Reluctant Adversaries: Canada and the People's Republic of China, 1949-1970, University of Toronto Press, 1991

139 K. P. Misra, India's Policy of Recognition of States and Governments, Allied Publishers, Bombay, 1966 
texts were not explored by those who have written on New Zealand's China policy. The existing literature has also not examined New Zealand's decision to recognise the PRC against the international law literature on the topic. ${ }^{142}$ However, there does not appear to have been a strong engagement with the details of international law by New Zealand officials, as they appear to have taken the approach that recognition was a political rather than legal act. This work will not provide a definitive analysis of New Zealand's decision to recognise Beijing but it will provide the strategic policy context for that decision which has been missing from the literature.

\subsubsection{New Zealand and the Great Proletarian Cultural Revolution}

No specific work on New Zealand's official views on the Cultural Revolution has been found for this research. However, there is significant scholarship on the revolution itself. The most prominent writer in the English language is Roderick MacFarquhar whose journalism on the revolution was popular amongst New Zealand officials at the time. ${ }^{143}$ MacFarquhar went on to write numerous texts including a three volume set on the Origins of the Cultural Revolution ${ }^{144}$ and, more recently, Mao's Last Revolution. ${ }^{145}$ Another important text is Barbara Barnouin and Yu Changgen's examination of Chinese foreign policy during the revolution. ${ }^{146}$ They argued it was a great achievement by the Chinese leadership to separate domestic politics from foreign policy in moving to establish relations with the West during the revolution, but Sino-American relations did not really improve until the ascendency of Deng Xiaoping in the late 1970s.

140 David C. Wolf, 'To Secure a Convenience': Britain Recognizes China - 1950', Journal of Contemporary History, Vol. 18, No. 2, April, 1983, pp. 299-326; R. Ovendale, 'Britain, the United States, and the Recognition of Communist China’, The Historical Journal, Vol. 26, 1983, pp. 139-158; Howard Schonberger, 'Peacemaking in Asia: The United States, Great Britain, and the Japanese Decision to Recognize Nationalist China, 1951-52’, Diplomatic History, Vol. 10, No. 1, January 1986, pp. 59-73

141 Robert P. Newman, Recognition of Communist China? A Study in Argument, Macmillan, New York, 1961; L. Thomas Galloway, Recognizing Foreign Governments: The Practice of the United States, Studies in Foreign Policy, American Enterprise Institute, Washington, 1978; Rosemary Foot, The Practice of Power: US Relations with China Since 1949, Clarendon Press, Oxford 1995; Warren Cohen, America's Response to China: A History of Sino-American Relations, CUP, New York, 2010

142 There is a significant body of work on recognition in international law. These are two major texts: Hersh Lauterpacht, Recognition in International Law, CUP, Cambridge, 1947; John Dugard and University of Cambridge, Recognition and the United Nations, Hersch Lauterpacht Memorial Lectures, No. 3, Grotius, Cambridge, 1987

143 See Chapter 4, Section 2

144 Roderick MacFarquhar, The Origins of the Cultural Revolution, Vols. 1-3, CUP, 1974, 1983, 1999

145 Roderick MacFarquhar and Michael Schoenhals, Mao's Last Revolution, Belknap Press, Cambridge, 2008

146 Barbara Barnouin and Yu Changgen, Chinese Foreign Policy During the Cultural Revolution, Kegan Paul International, New York, 1998 
One place where New Zealand officials witnessed the violence of the Cultural Revolution was Hong Kong. The riots there in 1967 have received some examination by scholars, most notably by Ray Yep and Robert Bickers in their edited volume May Days in Hong Kong: Riot and Emergency in $1967 .{ }^{147}$ However, all these texts fail to show the extreme confusion experienced by Western diplomatic observers, let alone the experience of New Zealand officials during this period.

\subsubsection{Cultural Factors}

Whereas the direct literature on New Zealand foreign policy on China in the Cold War is relatively limited, there is a wealth of literature on cultural and ethnic aspects of New Zealand-Chinese relations. ${ }^{148}$ This is on top of the literature published by New Zealanders on their experiences travelling in China. The most influential and prolific of these being Rewi Alley who has 191 publications in the New Zealand National Library. ${ }^{149}$

Victoria University Press itself has produced a large volume on Australasian cultural perspectives on China. ${ }^{150}$ This research described a cultural imagination, focused on the experience of ethnic Chinese in Australasia, and literary depictions of Chinese people in Australasian writing, including a chapter on Australian Cold War fears of China in popular culture. ${ }^{151}$ This thesis will not attempt any major analysis of intercultural aspects of New Zealand's understanding of China as the purpose of the thesis is to understand the opinions of policymakers.

New Zealand's experience of China during this time also includes stories from individual New Zealanders such as Rewi Alley who lived in China and wrote on life in Communist China. However, this research has found no evidence that those figures influenced New Zealand government policy during the period examined, with the exception of a small number of business people trading with China and providing information to the NZ Commission in Hong Kong. ${ }^{152}$

\footnotetext{
147 Ray Yep and Robert Bickers (eds.), May Days in Hong Kong: Riot and Emergency in 1967, Hong Kong University Press, Hong Kong, 2009

148 Scholefield and Hall, 1927; Fong, 1959; Ng, 1962; Greif, 1974; Ip, 2003 and 2009

149 National Library of New Zealand, http://nlnzcat.natlib.govt.nz/vwebv/search?searchType=7\&searchId=1224\&maxResultsPerPage=50\&recCo unt $=50 \&$ recPointer $=0$ \&resultPointer $=1$ \&headingId $=6740484$

150 Ferrall, Millar, and Smith (eds.), 2005

151 Timothy Kendall, 'Using the Past to Serve the Present: Renewing Australia’s Invasion Anxiety’, in Ferrall, Millar, and Smith (eds.), 2005, pp. 110-136

152 NZ Commission in Hong Kong to SecEx, 6 February 1968, ABHS W4628 6958 Box 46, NYP 3/16/1 Vol. 6, Political Affairs - China - General, 1967-68
} 


\subsection{GAPS IN THE LITERATURE}

Very little high level academic research has been done on New Zealand's official understanding of China between 1965 and 1972, and none that emphasizes the strategic elements of New Zealand policy. The work that has been done either had little access to official records; did not explore the entire period covered in this research; or ignored the wider alliance system. Much of the focus has been on the issue of recognition but none have placed recognition in a strategic context. Writing on New Zealand's cultural relations with China and on post-recognition relations is extremely well developed when compared to the 1965-1972 literature. Defence, alliance, and war literature is well developed but tends to avoid discussing China in favour of armed conflict issues in South East Asia or US-NZ relations. Similarly, writing on New Zealand individuals who travelled to communist countries or espoused communist beliefs lacks a wider strategic or foreign policy context. The literature on New Zealand and the Soviet Union is also weak with only two major volumes, but this research shows that China was much more important to defence policymakers than the Soviet Union during the period examined. ${ }^{153}$

This research looks directly at the assessments generated by New Zealand's diplomatic and defence apparatuses. It brings those assessments together to build a picture of what New Zealand understood about Beijing's intentions as an international actor and what influenced New Zealand's outlook on China. The change of opinion on recognition is part of this story but the reasons for the change in policy and the forces that influenced New Zealand assessments is far more important than the act of recognition itself. New Zealand did not possess (like the UK), ${ }^{154}$ nor (like the US) ${ }^{155}$ could it build, a large academic and bureaucratic base to study states deemed to be threats. This has meant that there is not an obvious New Zealand literature on China as a potential threat in the same way that existed in the UK or the US. Yet, while New Zealand officials did not have the same capacity to collect or analyse intelligence on the communist powers, New Zealand governments nevertheless still had to make assessments on these countries as part of a strategy of engagements in alliances and multilateral institutions. New Zealand had its own diplomats and defence officials who had to make these assessments and then make recommendations

\footnotetext{
153 Wilson, 2004; Trapeznik and Fox, 2004

154 Keith Jeffery, MI6: The History of the Secret Intelligence Service 1909-1949, Bloomsbury Paperbacks, 2011

155 David C. Engerman, Know Your Enemy: The Rise and Fall of America's Soviet Experts, New York, OUP USA, 2010
} 
to their ministers. Now that most of these files have been released and China is again becoming the focus of Asian security, it is timely that the construction of New Zealand's Cold War China policy is examined properly.

\subsection{TIME PERIOD}

The time period being examined starts soon after the Ministry of Defence was created officially by the Defence Act $1964^{156}$ and continues through to Wellington's official recognition of the PRC in 1972. The opening year was chosen as it was the first year that the separate Ministry of Defence was in full operation; the start of a new defence review process began early that year, and it represented the cross-over of Confrontation and the American military build-up in Vietnam. The year 1972 provides a logical end-point for two reasons. That year saw the release of the Review of Defence Policy 1972, the first since the 1966 review which the Ministry of Defence had begun work on in 1965 . The 1972 review is notable for the dramatic change from the previous review as China was no longer referred to as a central threat, Britain and the US were making a military exit from mainland South East Asia, and the purpose of New Zealand's role in South East Asia had changed dramatically. The other important event in 1972 is the Third Labour Government establishing official relations with Beijing upon entering office at the end of that year. The time period from 1965 to 1972 therefore represents the peak and fall of New Zealand's Cold War security concerns from China. It is also the period that has been least explored by New Zealand scholars.

\subsection{METHOD AND SOURCES}

This work uses the historical method. While diplomacy and defence are the subjects of the research here, this work is not a diplomatic history in the traditional sense, as that implies a transactional relationship which was not present during the period examined. The level of government-to-government contact between China and New Zealand was extremely limited. For this reason, this work focuses on New Zealand's perception of China and how New Zealand officials assessed the information on the PRC that was available to them. The

\footnotetext{
156 'An Act to establish the Ministry of Defence and to provide a unified defence policy for the better defence of New Zealand', NZ Parliament, November 1964, http://www.nzlii.org/nz/legis/hist_act/da19641964n6783/
} 
primary data set for this research is archival material from the Department of External Affairs (and its successor the Ministry of Foreign Affairs) and the Ministry of Defence.

This thesis targets the groups providing information to the Government and forming military strategy. While Cabinet made the ultimate decisions on military spending and use of military force overseas, senior officials were the ones that designed the detail of New Zealand's foreign and defence policy. The reviews of defence policy were written by senior military and civilian officials and then approved (but not always funded) by Cabinet. The defence review process provides the best insight into the formulation of New Zealand's grand strategy. The review process involved a reassessment of the assumptions that underlay New Zealand defence policy from first principles. Defence reviews involved input from the Ministry of Defence, the Chiefs of Staff, External Affairs, and the Joint Intelligence Committee. It is this nexus between the military leadership, the civilian bureaucratic leadership, and the elected leadership in Cabinet that is important for understanding the full complexity of New Zealand strategy.

The key, newly available, sources are the files relating to the defence review process beginning in early 1965 and continuing through 1969. Later defence policy documents have been examined but China ceases to be a major factor in defence policy-making from 1969. These files provide insight into what these organisations thought the threats to New Zealand were and what was necessary to meet them. These files provide important findings about official attitudes towards China that were not available publicly before 2012. China is identified as the most important long-term threat to New Zealand's interests between 1965 and 1968. From this point onwards the files of the Ministry of Foreign Affairs become more important as China policy becomes an issue more for diplomats than defence officials.

As New Zealand had no official relations with the PRC until 1972, information from China was handled by New Zealand posts outside Communist China. The New Zealand Commission in Hong Kong was by far the most active China watcher of New Zealand's diplomatic missions. The embassy in Washington and the permanent mission to the United Nations were also very active in providing information on China and the China policies of New Zealand's partners, but it was the commission in Hong Kong that provided the clearest opinions on events in China. The commission had a good relationship with the British 
Embassy in Beijing ${ }^{157}$ which passed on significant amounts of information. Not all the files of the commission are available but much of their material can be found in files of other missions.

By bringing together the most recently available archival material this research goes beyond New Zealand's search for security in the Cold War and investigates the assumptions that were made about Communist China during this period. This does not mean narrowly investigating policy on China, but looking at the wider strategic picture and finding how China fitted into New Zealand's wider grand strategy. Previous research looked at specific conflicts or specific alliances. This work improves on previous research by having access to previously closed defence files allowing an examination of the broad sweep of New Zealand defence strategy and China's place in it.

\subsection{INTERVIEWS}

A small number of interviews were attempted for this research, but few senior officials from this time remain alive and in good health. Those interviews provided no significant additional information and have not been included in the text here.

\subsection{ORGANISATIONS EXPLORED}

The defence policymaking process involved a number of organisations that will be explored in this work. However, the overall policymaking community was small. Staff were regularly seconded between departments and staff from the Ministry of External Affairs often had a hand in defence planning at the Ministry of Defence. The role of Assistant Secretary (Policy) at the Ministry of Defence was typically held by a staff member from External Affairs during the time period being explored in this work. For example, Paul Edmonds and Norman Farrell both held this post and both served as New Zealand's ambassador to South Vietnam. Edmonds played a significant role in the creation of the Review of Defence Policy 1972. Of particular importance is Ralph Mullins who served as both head of the Defence Division at the Ministry of External Affairs and as chairman of the Joint Intelligence Committee. As the following chapters describe, Mullins was instrumental in shifting the defence establishment's view on China during the late 1960s.

\footnotetext{
${ }^{157}$ During this period, the British diplomatic mission in Beijing is sometimes referred to as a legation rather than an embassy as the PRC refused to an exchange of ambassadors with the UK until 1972. However, New Zealand and UK diplomats referred to it an embassy prior to 1972, so this thesis will refer to it as such.
} 
Despite the close relationship between the two departments, institutional forces and interests were major factors. Staff may have worked across departments but the self-interest of the individual services, the military as a whole, and the individual civilian departments is still evident in their assessments of military need and external threat. The policymaking process evolved over time and each defence review was developed differently. Nevertheless, the process was typically bottom-up with officials at the Ministry of Defence creating a basic outline of New Zealand's defence needs which was then augmented with intelligence assessments, foreign policy goals, the views of the Chiefs of Staff, and then the spending needs of the individual services. Once spending needs had been developed they were examined by Treasury which had significant influence over the financial implications of the reviews.

The Defence Council was New Zealand's primary defence policymaking body. It was made up of the Minister of Defence (who acted as chair), the Chiefs of Staff (who also had their own committee and met regularly), and the Secretary of Defence. The council could co-opt other members and this meant the Secretary of Foreign Affairs and the Secretary of the Treasury were usually present at Defence Council meetings. ${ }^{158}$

More secretive was the Joint Intelligence Committee which provided reports on the military threats New Zealand could face over the next few years. There were also Joint Intelligence Committees in Australia, Canada, and the UK with whom the New Zealand JIC shared information. The British committee was broken into regional bodies with the Far East division handling China and New Zealand. The reports of the JIC provide the clearest picture of New Zealand's view of China and the extent to which it was perceived as a threat to New Zealand interests. As China changed during the Cultural Revolution so did the JIC assessment of the threat. The JIC presented its findings to the Defence Council and while the council would not reject findings of the JIC it disagreed with, it would ask for greater detail if it found a JIC report contentious.

Sitting above the Defence Council was the Cabinet Defence Committee which existed as a Cabinet sub-committee. Its role in policy and strategy formation was relatively small despite having the Prime Minister and the Defence Minister as members. Much of the discussion recorded in the $\mathrm{CDC}$ relates to confirming elements of the defence reviews or discussing defence financing.

158 Section H-4 of the AJHRs 1965-1972 lists the members of the Defence Council 
External Affairs and Treasury were the outside departments with the most influence on defence policy. External Affairs provided the foreign policy goals that defence policy was required to meet and Treasury would examine the cost of defence expenditure. Occasionally these pressures come up against the institutional interests of the military. Much of the time in the review process was spent establishing the quantum of the defence vote.

External Affairs was the primary conduit of information on China. As noted, its commission in Hong Kong provided the greatest collector and analyser of information on events in China. Other missions provided information in their dealings with their host countries, but were less forthcoming with their own opinions than their colleagues in Hong Kong. As China policy moved from the military to the diplomatic sphere, External Affairs became the lead agency. This became especially important as China entered the UN and Wellington moved towards recognition.

\subsection{LIMITATIONS}

As the data set comes primarily from archival material it will have many of the same limitations of archival research in general. Much of the file material for the period from the Ministry of Defence was declassified in 2012. However, a researcher can never be sure of what remains classified, has been destroyed, or was never committed to paper in the first place. Many of the Joint Intelligence Committee reports have been declassified either individually or as parts of other files, but the minutes of the JIC's meetings remain classified. Similarly, very little from the Joint Intelligence Bureau (the forerunner to the National Assessments Bureau) is available publicly at the time of writing. Restrictions also exist on files relating to the recognition of China in 1972, but this has not affected the quality of the thesis as it is the files covering the previous eight years that provide the real context for understanding the decision. 


\section{THE DEFENCE REVIEW PROCESS OF 1965}

\subsection{INTRODUCTION}

This conviction that the Chinese and their allies must be shown that they cannot win permeates American thinking on negotiations, pauses in their bombing activities, dealings with the Viet Cong [sic]. They are determined to turn the tide in Vietnam not solely "to prevent South-east Asia going Communist" but because they are convinced that the Vietnam war [sic] has become the key to the whole global balance of power. If escalation reached this point where the Chinese (with 700 million people) intervened with massive land forces, the United States (with 190 million people) could not be expected to confine its reaction to conventional forces as it had in Korea, at a cost of 100,000 casualties. ${ }^{159}$ - Holyoake's report to cabinet on the ANZUS Council meeting 28 June 1965.

The prospect is therefore for a disturbed and unstable South-east Asia, overshadowed by the power of a militant and expansionist Communist China which is hostile to our way of life, and at the same time a withdrawal of British power from this vital area. The combination of these two factors (coupled of course with the major American confrontation with Communist power in Vietnam) will present us with defence problems of a type we have not had to consider at any previous stage in our history. ${ }^{160}$ Draft Cabinet Paper, November 1965.

The end of 1964 saw the culmination of several converging pressures for New Zealand's foreign policy makers. These pressures represented both short and long-term problems requiring Cabinet to make decisions on the direction of New Zealand's strategic position in Asia. The Malaysia-Indonesia Confrontation was continuing and the situation in Vietnam was worsening. These problems were seen in the context of an increasing risk of limited war with China. While the risk of global war was receding, New Zealand was finding itself in a position where its defence forces could be fully deployed to conflicts in South East Asia, conflicts which could escalate into direct but limited war with China. In December of 1964 the Defence Council warned that New Zealand could be at war with both Indonesia and China within six months. ${ }^{161}$ Much of the country's military equipment was obsolete and there was a new sense of urgency in the upgrading of the services. New Zealand's limited

159 'ANZUS Council Meeting, Washington, Report to Cabinet', 28 June 1965, ABHS W5422 950 Box 34, 111/3/3/15 Vol. 8, International Affairs: Security Pacific Pact, ANZUS Council Meetings, 1968-1970

${ }^{160}$ Untitled draft report to Cabinet, SecDef to MinDef, 9 November 1965, MoD 1/1/2 Vol. 2, New Zealand Defence Policy - Review of Defence Policy, 1965-1966

161 'Likely developments in South East Asia up to June 1965 and their military consequences for New Zealand', Defence Council Memo to Cabinet, Chief of Defence Staff to MinDef, 11 December 1964, MoD 1/1/1 Part 1, New Zealand Defence Policy - Policy - General, 1961-1968 
resources necessitated careful decisions on both acquisition and deployment. The defence community believed a decision needed to be made quickly as to whether the American effort in Vietnam or the defence of Malaysia and Singapore should be the focus of New Zealand's efforts.

Even if escalation did not occur, both conflicts were seen as having longer term implications for the containment of China. New Zealand's Forward Defence strategy was dependent on British bases in South East Asia. As Britain prepared to draw down its involvement in Asia, New Zealand's ability to forward deploy forces in Asia became less secure. New Zealand and Australia were not certain their presence would remain welcome in their host nations but they were certain China could not be contained without a British or American presence on the Asian mainland. Evaporating British interest necessitated greater American cooperation with which New Zealand still had little practical experience. This would mean support for the endeavour in Vietnam despite reservations about the South Vietnamese regime, the risk of Chinese intervention, and the limits of domestic approval. ${ }^{162}$ The divorce of Singapore from Malaysia in August 1965 added an extra level of complexity to an increasingly difficult situation. The need to keep the British and Americans on the ground in South East Asia was reinforced by a lack of confidence in the sustainability of Malaysia and Singapore as political units, let alone their ability to defend themselves from Chinese Communist aggression or subversion.

These challenges came just as a single civilian Ministry of Defence was created to oversee the planning of New Zealand's three military services. As part of this reform a complete review of defence policy was undertaken. New Zealand's defence policy had already seen reviews and white papers in 1957, 1961, and again in 1963. This review would be different. While those earlier reviews were essentially white papers reporting on the decisions made by Cabinet, this review was to be a complete re-examination of New Zealand's strategic outlook and the forces required to meet New Zealand's policy goals. Such a revaluation from first principles required the report to be a highly classified New Zealand-eyes-only exercise which could be then transformed into a public document justifying the decisions once they had been made. ${ }^{163}$ The classified versions of the review provide a clear demonstration of the defence establishment's thinking on the wider strategic environment

\footnotetext{
162 Note that domestic political considerations were rarely mentioned in defence policy documents at this time, but it was a major consideration for Cabinet.

163 Hunn, SecDef, to Chiefs, 22 January 1965, MoD 1/1/2 Vol. 1, Review of Defence Policy, 1964-1965
} 
and future developments to the year 1970. The newly established coordination of the defence vote meant that an integrated approach to strategic analysis and defence acquisition could be undertaken for the first time. The review began in haste but slowed considerably, partly due to the parallel decision to commit forces to Vietnam and partly due to Treasury's opposition to the spending implications of the review.

Institutional politics would play out in the guise of strategic analysis as the Secretary of Defence Jack Hunn argued unsuccessfully for the integration of the three services as part of the defence review. Hunn argued against participation in the Vietnam War, seeing the conflicts of South East Asia as being driven primarily by the forces of decolonisation rather than communist ideology. Such a view led him to make strategic arguments that grossly overestimated the future of Chinese power in South East Asia. Hunn favoured a defence structure that would emphasise home defence over limited warfare in Asia, yet was still capable of assisting major allies in foreign conflicts. Hunn's lack of success in implementing his vision stemmed from institutional opposition from the three services but also from the easy rebuttal of his strategic arguments. The year would end with a review of defence policy that was nearly complete but had been overshadowed by the commitment in Vietnam, the opposition of Treasury to the Ministry's spending requests, and the resignation of Jack Hunn.

\subsection{A Fresh Defence ReVIeW}

The endeavour that became the Review of Defence Policy 1966 did not begin in optimistic circumstances. A review had been planned as part of the merger of the Air, Naval, and Army departments, ${ }^{164}$ but it was made a priority after a Defence Council report which declared that New Zealand could be 'at war' with China and/or Indonesia within six months. ${ }^{165}$ In December 1964, the Defence Minister, Dean Eyre, called for a new review including a finance programme to be produced for consideration by the Defence Council by February 1965. ${ }^{166}$ While the important first draft would appear quickly, the review would take over a year, by which time the strategic circumstances had begun to change and the 1966 review would become the basis for a period of near constant re-evaluation which lasted into the 1970s.

\footnotetext{
164 SecDef to MinDef, 14 August 1965, MoD 1/1/1/ Part 1

165 Chief of Defence Staff to MinDef, 11 December 1964, MoD 1/1/1 Part 1

166 MinDef to SecDef \& CoDS, 14 December 1964, MoD 1/1/2 Part 1
} 
The process was slowed by disagreements with Treasury and by Cabinet which deferred several decisions. Disagreements would also come from within as the chiefs of the three services argued with each other over their share of the newly combined defence vote, while together they argued with the Secretary of Defence to keep their individual organisational independence. Yet, there was largely agreement on the overall strategic situation and the centrality of China to that outlook. The bigger challenges were deciding on the force structure that would best serve New Zealand's participation in low intensity conflicts and limited wars in South East Asia and how that structure could be financed.

Fears of escalation in Vietnam or Borneo came as a major modernisation programme was being implemented, but this did not represent a major expansion in New Zealand's capability. In December 1964, the Chief of the Defence Staff, Vice Admiral Peter Phipps, warned the Minister that the existing re-equipment programme, which had begun in 1963, would bring the services up only to their 'immediate minimum needs'. ${ }^{167}$ The existing plan was to be completed in 1968 and thus there was suddenly a sense of urgency in expanding the programme. Phipps argued a crash programme should be avoided, but a new defence review was required to try and re-equip the services faster and avoid deferring decisions which would create delays. ${ }^{168}$

The first draft of the strategic arguments for the review was produced by the Ministry of Defence in a little over a week during January 1965. This draft was supplemented with two paragraphs by the Joint Intelligence Committee the following month. ${ }^{169}$ This was more than a rough first step in a long process. This early version was designed to be secret statement which laid out the threats and pressures faced by New Zealand's interests and military. This highly classified draft then formed the basis of capability planning for the final version of the review. The final public statement was, as originally intended, washed of its blunter statements of threat. ${ }^{170}$ Therefore, the January 1965 draft provides a detailed snapshot of the views of the new Ministry of Defence and New Zealand's strategic direction.

As well as the JIC, the Defence Council, and the Chiefs of Staff would make amendments as the review developed. The attempt was to write a review that would see the military through to 1970 . This time-frame was also the longest the JIC was willing to accept as it felt it was impossible to make predictions more than five years out. The JIC pointed to several aspects

\footnotetext{
167 Chief of Defence Staff to MinDef, 11 December 1964, MoD 1/1/1 Part 1

168 Chief of Defence Staff to MinDef, 11 December 1964, MoD 1/1/1 Part 1

169 JIC Meeting, (JIC(65)M.3), 3 February 1965, MoD 1/1/2 Part 1

170 Hunn, SecDef, to Chiefs, 22 January 1965, MoD 1/1/2 Vol. 1
} 
that would have an effect on New Zealand's interests that were difficult to predict: the outcome of the Vietnam War, Konfrontasi, the power struggle in Indonesia, and the effect of China's scientific developments. ${ }^{171}$

Some of the details on the wider strategic picture would be removed before the final draft could be given a public release, but the early draft represented the strategic picture that was presented to Cabinet and underpinned the force structure recommended to the Defence Minister and Treasury. The services all drafted their own reports on the size and shape of the forces required and then these were reviewed by the other bodies. ${ }^{172}$ However, the changes recommended by those bodies were fairly minor and the overall assessment did not change through the reviews of the draft, as New Zealand's defence community was largely in agreement with the overall strategic picture.

\subsection{StRATEgIC AsSUMPTIONS}

While the objective of the review exercise was a complete reassessment of the assumptions of New Zealand's defence, the Ministry was quick to dismiss a radical move away from active or passive participation in Western alliances and towards neutrality. Collective defence - either through the UN or through Western alliances - had been the basis of the bipartisan defence consensus since the end of the Second World War. ${ }^{173}$ New Zealand was not seen as having the population or the industrial base to ever be able to defend itself from a power that was capable of crossing the oceans and landing a force on New Zealand shores. Associated with the assumption of commitment to collective defence was the assumption that communist governments would pose the core security challenge.

Given the nature of the Communist threat to South East Asia... our relations with Communist China and the Soviet Union, and any Communist-orientated governments in the area, must at best be wary and suspicious and at worst frankly hostile. ${ }^{174}$

New Zealand's security would still be obtained through commitment to alliances but the focus would remain on South East Asia and not Europe or the Middle East which had been part of New Zealand military planning until the early 1950s. ${ }^{175}$ This was partly due to

\footnotetext{
171 G.H. Duncum, SecJIC to SecCoS, 22 February 1965, MoD 1/1/2 Part 1

172 R.L. Jermyn, SecDef to SecExt and SecTreasury, 9 February 1965, MoD 1/1/2 Part 1

173 Ian McGibbon, 'The Defence of New Zealand 1945-1957', in New Zealand in World Affairs Volume 1: 1945-1957, Price Milburn, Wellington, $2^{\text {nd }}$ Edition, 1991, p. 147

174 'New Zealand Defence policy up to 1970', Draft A, 9 February 1965, MoD 1/1/2 Part 1

175 McIntyre, 1995, pp. 191-210; Jim Rolfe, 2005, p. 42
} 
changes in military technology but it was primarily due to New Zealand's proximity to the relative instability of South East Asia. New Zealand's interests were not limited to South East Asia, but the South Pacific and Antarctica presented comparatively few challenges.

Given these core assumptions, the objectives of New Zealand's defence forces were defined as:

- $\quad$ contributing to the security of New Zealand and its territories;

- $\quad$ to back New Zealand's political objectives through collective security at the level of the UN or regional agreements thus allowing small states to deter larger aggressors;

- $\quad$ establishing a claim to protection in the event of a major conflict from allies by demonstrating a willingness to assist them in pursing their national interests;

- $\quad$ have the ability to deploy armed force in the South Pacific in situations that affect New Zealand's interests but not those of its allies;

- $\quad$ and ensuring the best use of the limited resources available. ${ }^{176}$

By the time of the review the global geo-strategic position was considered stable by the Ministry of Defence as the US and the USSR were expected to act carefully in their relations. The need for great power stability brought on by the Cuban Missile Crisis had reduced risks - if not tensions - in the Western Hemisphere but for officials in Wellington this also highlighted the comparative lack of stability in South East Asia. There the forces of decolonisation would continue to cause instability and as new powers jostled with one another, possibly even causing the breakdown of the bipolar model.

As the reluctance of the major powers to exercise their full military capabilities has become more evident, both the eastern and western blocs have shown increasing signs of disintegration. This fact, coupled with the emergence of a large number of newly independent states, has given secondary powers such as Indonesia the opportunity to become more unrestrained in pursuit of their regional ambitions. In consequence there is a general trend in the undeveloped areas of the world towards increasing diversity and disorder. ${ }^{177}$

\footnotetext{
176 Draft 'Review of New Zealand Defence policy up to 1970', January 1965, MoD 1/1/2 Part 1

177 'New Zealand Defence 1965-1970', February 1965, MoD 1/1/2 Part 1
} 
Therefore, while the risk of a global conflict involving nuclear weapons was considered quite low, the threat of a major 'limited' conflict that necessitated a major military contribution by New Zealand was thought to be rising: '[The] possibility that NZ could be involved in hostilities requiring the participation of most or all of our defence forces has substantially increased. ${ }^{178}$ The maintenance of Forward Defence was considered crucial to meeting the threats created by this instability. This meant the active and continued cooperation of the major Western powers in the region which, in itself, was a challenge to the forces of decolonisation.

While in the period under review there is a risk of loss of the Malaysian bases, a development which would make a defence posture forward of the Australian mainland almost impossible to sustain; the forward defence concept is still viable as the best means of ensuring the effective defence of New Zealand during the period up to 1970 . However this concept depends entirely on the maintenance of a United States presence in mainland South East Asia, and a major British commitment in Malaysia. We must take every step possible to sustain the resolve of our two major allies to maintain these commitments in South East Asia. ${ }^{179}$

The draft review had a particularly pessimistic tone. It noted the difficulties in keeping the UK and US interested in the region, the short-term challenges of stabilising the new states of the region, and the longer term problems of China's growing military strength and the pressure of decolonisation pushing New Zealand out of the region.

Looking beyond the immediate period to 1970, it must be recognized that the longer term prospects are similarly darker. There is a real possibility that the combined or separate results of Asian Communist pressure and Indonesian enmity will virtually bring a completely hostile 'front line' over a thousand miles closer to Australia, New Zealand and the Pacific Islands, either within the five-year period or soon after. Furthermore, well within the next ten years it may be expected that our potential enemies, besides being closer, will be much more effective in all forms of, at least conventional, warfare. ${ }^{180}$

Despite the attempt at a clean slate for New Zealand's defence thinking, the basic policy goal was only expressed implicitly. New Zealand wanted to avoid all of South East Asia being controlled by a hostile power as Japan had achieved between 1942 and 1945. A hostile 'front line' set at Australia's coast was not acceptable to Wellington. South East Asia represented both a buffer and forward platform of operations. New Zealand's defence policy

\footnotetext{
178 Draft 'Review of New Zealand Defence policy up to 1970', January 1965, MoD 1/1/2 Part 1

179 'New Zealand Defence 1965-1970', February 1965, MoD 1/1/2 Part 1

180 'New Zealand Defence 1965-1970', February 1965, MoD 1/1/2 Part 1
} 
had to preserve both those elements through active participation in conflicts, diplomatic efforts with Western and Asian allies, and the development of forces that complimented allied efforts while making the best use of New Zealand's limited resources. The extent of the effort required by New Zealand would be dependent on the kind of conflict that emerged in Asia and consequently making such predictions was a major aspect of the defence review.

\title{
2.4 The CATEgories of CONFLict
}

New Zealand defence planners divided potential conflicts into three distinct categories: global war, limited war, and operations below limited war. Global war was envisioned as a conflict that would involve both superpowers in direct conflict with one another in multiple theatres across the world. It was assumed that such a conflict would involve the use of nuclear weapons, but those weapons would probably not be used against the New Zealand area. A limited war would be restricted to the South East Asian region but would involve the use of large numbers of conventional forces including naval and air power. Such a conflict would be akin to the Korean War but would take into account the technological developments since then. A limited war was assumed to involve either PRC or Indonesia as North Vietnam was not considered in 1965 to be able to sustain a limited war against the US. ${ }^{181}$ It is unclear whether New Zealand defence planners expected the use of nuclear weapons in a limited war in South East Asia but they did not appear to rule out the use of nuclear weapons by Western powers in either a tactical or strategic application. It is certainly clear that New Zealand's military planners thought it was possible that New Zealand could be involved in a nuclear conflict involving China. As a 1966 paper put it:

\begin{abstract}
Although China will have a limited nuclear capability by 1970, it is unlikely that the Chinese will have sufficient means of delivery in this time frame to use nuclear weapons in a limited war situation. However, in the event of a major Chinese attack in the SEATO area, the use of tactical nuclear weapons by our allies remains a possibility, although any decision to use nuclear [weapons] will be made at the highest political level. New Zealand forces must therefore be capable of operating in a nuclear and CW/BW [Chemical Warfare/Biological Warfare] environment. ${ }^{182}$
\end{abstract}

Conflicts below the level of limited war were not categorised as clearly by defence officials. They were referred to regularly with terms such as insurgency, subversion, guerrilla warfare and, occasionally, terrorism which all seem to be used interchangeably. For the purposes of

181 'New Zealand Defence Policy 1965-1970', MoD 1/1/2 Vol. 2

182 'The NZ Army Concept of Operations 1966-70 (Provisional)', February 1966, MoD 1/1/2 Vol. 2 
this research such conflict will be referred to as low intensity warfare. This form of warfare implied the avoidance of outright belligerency but it was seen as part of a continuum of violence that flowed into limited war as the use of regular military units and heavy weapons increased. Despite being poorly defined, it was low intensity conflict that was considered to be the type of conflict New Zealand forces were most likely to face from Indonesia, North Vietnam, or even China. New Zealand was already involved in this kind of conflict in Borneo fighting small units of the Indonesian military involved in the incursions into Malaysia. ${ }^{183}$ However, the conflicts in Vietnam and Malaysia also had the potential to escalate and thus require greater participation by New Zealand. Planners felt the upsurge in violence in Borneo and Vietnam over the previous two years had greatly increased the likelihood that New Zealand could find itself involved in a limited war with China. ${ }^{184}$ The two conflicts were similar in their potential for increased New Zealand participation but were treated differently in their connections to New Zealand's interests and New Zealand's alliance relationships.

\subsection{INDONESIA AND KONFRONTASI}

Indonesia's policy of confrontation with Malaysia had been running for nearly two years by the time of the early drafts of the defence review. Malaysia was home to the Commonwealth Strategic Reserve and thus its defence was a priority for New Zealand, Australia, and the UK. The emergence of Konfrontasi and its threat of escalation into a high-intensity limited war had not been foreseen in the Defence White Paper of 1961. ${ }^{185}$ By early 1965 planners saw little prospect of Indonesia moving away from confrontation with Malaysia, even if a change of leadership were to occur in Djakarta. Sukarno's thinking was poorly understood in Wellington but officials believed, correctly, that Konfrontasi was driven largely by his need to balance the division between the military and the Chinese supported Indonesian Communist Party (PKI). ${ }^{186}$ Indonesia's relationship with the UK was known by planners to be extremely poor but the direction of Djakarta's relationship with China was less clear due to the hostility of the Indonesian military to Beijing. Australia's proximity to Indonesia made Konfrontasi a priority for Canberra but for Wellington it was an ongoing distraction from the longer term threat from China. Thus Indonesia was considered by defence planners to be an

\footnotetext{
183 Pugsley, 2003

184 'New Zealand Defence Policy 1965-1970', MoD 1/1/2 Vol. 2

185 'Review of Defence Policy', AJHR, Vol 1, A. 8, 1961

186 Draft 'Review of New Zealand Defence policy up to 1970', January 1965, MoD 1/1/2 Part 1
} 
extra problem compounding existing problems. Yet in 1965 it seemed like a problem that would not go away. New Zealand planners believed Indonesian hostility would remain through the period to 1970 regardless of whether the PKI was able to take control of the country.

[Konfrontasi] is a development which could involve New Zealand at any time during the period 1965-1970 in either localised fighting requiring the sustained employment of NZ units or in full-scale hostilities. Perhaps the most serious consequence for $\mathrm{NZ}$ defence planning, however, is that $\mathrm{NZ}$ and her allies in the South-East Asian area may become involved simultaneously in hostilities with Indonesia and Communist China. ${ }^{187}$

The defence of Malaysia was a problem that affected ANZAM specifically and attracted little interest from SEATO or the United States. The threat from Indonesia was compounded by the fragility of Malaysia. Wellington planners were not convinced that Malaysia would survive as a single political entity to the year 1970, regardless of how much support was provided by its ANZAM partners. The breakup of Malaysia was considered a disastrous prospect for New Zealand as that would imperil its bases in Malaysia. ${ }^{188}$ Assuming it was possible for Malaysia to survive until at least 1970, the review called for the acceleration of Malaysia's integration into ANZAM planning. Malaysia was not considered likely to join SEATO but the growth of Malaysian military capabilities into the late 1960s still necessitated its closer integration with Commonwealth defence planning with benefits for SEATO defensive preparations. ${ }^{189}$ The development of Malaysia's military into a force that could defend itself was the ideal, despite scepticism from New Zealand planners.

British interests in the Far East were fading as the costs of its global capabilities were growing beyond its economic resources, but it remained committed to the defence of Malaysia. This declining interest was a major concern to New Zealand planners. British disengagement was being limited by residual colonial responsibility for the defence of its empire, including New Zealand and Australia, but the UK also remained committed to protecting its oil interests in Brunei. ${ }^{190}$ The US was much less interested in the problems faced by Malaysia as it was less receptive to British colonial interests and more concerned with preventing the spread of communism. American diplomacy with Indonesia was delicate

187 Draft 'Review of New Zealand Defence policy up to 1970', January 1965, MoD 1/1/2 Part 1

188 Draft 'Review of New Zealand Defence policy up to 1970', January 1965, MoD 1/1/2 Part 1

189 'New Zealand Defence 1965-1970', February 1965, MoD 1/1/2 Part 1

190 British forces put down a revolt in Brunei in 1962 leading to it not being included in the Federation of Malaysia. See: Harun Abdul Majid, Rebellion in Brunei: The 1962 Revolt, Imperialism, Confrontation and Oil, I. B. Tauris, London, 2007 
as Washington had tried to engage with Djakarta while trying not to involve itself in Sukarno's post-colonial ambitions. ${ }^{191}$ Obtaining greater American interest in the security of Malaysia and Singapore would be one of the great aims, and great failures, of New Zealand policy throughout the Forward Defence era.

New Zealand planners did not want to see a revitalisation of the concept of Maphilindo - a union of Malaya, Indonesia, and the Philippines proposed in 1963 - even if that would help bring an end to Konfrontasi. ${ }^{192}$ If Maphilindo were to be resurrected the Ministry of Defence believed it would inevitably become dominated by Indonesia and thus would lead to abrogation of the Anglo-Malysian Defence Agreement. Yet Maphilindo was seen as having advantages in terms of creating a forum for the resolution of the hostility towards Malaysia or even as a future counterweight to China. As it stood Beijing was seen as having an incentive to encourage Indonesian hostility toward Malaysia even if Chinese communist and Indonesian nationalist interests were unlikely to stay aligned for long. However, both Chinese influence and peace driven by Indonesian nationalism would be at the cost of Western interests in the region.

...there is little short-term comfort to the West in speculating whether the interests of an expansionist nationalist Indonesia and those of Communist China are really compatible in the longer term. ${ }^{193}$

If Maphilindo were to re-emerge and was dominated by Djakarta, then New Zealand and Australia would likely lose their basing rights in Malaysia and the degree of influence they had over Malaysia and the region generally. In short, Malaysia was considered a weak but vital ally by Wellington. Its British bases were New Zealand's platform for the containment of China which New Zealand had a vital interest in maintaining regardless of the future direction of Indonesia-Malaysian relations. The loss of those bases would mean the end of Forward Defence.

It was Britain's involvement in South East Asia that was the practical basis of Australia and New Zealand's military presence in South East Asia. SEATO may have been the organisation that coordinated and legitimised New Zealand's part in the containment of China, but New Zealand's logistical capacity was almost completely dependent on the other ANZAM nations meeting their commitments to SEATO plans. Coordinating with the UK

191 Damien Fenton, To Cage the Red Dragon, NUS Press, Singapore, 2012, p. 225

192 Draft 'Review of New Zealand Defence policy up to 1970', January 1965, MoD 1/1/2 Part 1

193 Draft 'Review of New Zealand Defence policy up to 1970', January 1965, MoD 1/1/2 Part 1 
and Australia was simpler and had direct spin-offs for SEATO planning. The Commonwealth Strategic Reserve was therefore not perfectly compatible with SEATO but the overlap was significant enough to suit New Zealand. New Zealand's military hardware, systems, and personnel easily operated within the CSR framework but the political goals of Malaysia and the UK were secondary to the containment of China in the eyes of New Zealand planners. As the January draft review noted:

Up to the Malaysian crisis, the planning done by Britain, Australia and New Zealand in ANZAM made excellent military sense in terms of coordinating Commonwealth participation in SEATO operations, but politically - for Australia and New Zealand at least - its objectives became purely secondary to broader SEATO interests. ${ }^{194}$

Those broader SEATO interests were the plans that prepared for war with China and/or a large-scale communist insurgency. The decline in British military interest in Asia was therefore a significant problem for New Zealand's interest in maintaining its place in Asia and the containment of China generally. Kronfrontasi presented New Zealand with a strange perverse incentive as it had renewed British interest in South East Asia and delayed the withdrawal of British forces from the region. Battling Confrontation could be seen as being part of New Zealand's general ongoing military assistance to Malaysia although it was not in New Zealand's interest to let the conflict escalate. There was significant pessimism about the fight against Confrontation amongst New Zealand officials when compared to their British counterparts in discussions in early 1966. ${ }^{195}$ New Zealand's isolation from Indonesia was also a factor when comparing Australia's much greater concern with the immediate defence of Papua New Guinea and the Australian mainland. Australia was looking in vain for assurances from the US should it find itself in a major conflict with Indonesia. ${ }^{196}$

The Confrontation represented one of two serious short-term problems faced by defence planners in early 1965. It was in many ways the easier problem for New Zealand. Indonesia did not pose the same threat as China, but it did have the potential to dominate Malaysia and force the withdrawal of the Western forces that New Zealand considered necessary for the containment of China. Confrontation was a problem shared with New Zealand's two closest alliance partners, Australia and the United Kingdom. New Zealand could operate out of British bases in Malaysia supported by British and Australian logistical capabilities. Yet

\footnotetext{
194 Draft 'Review of New Zealand Defence policy up to 1970', January 1965, MoD 1/1/2 Part 1

195 'Defence Talks, Canberra', February 1966, MoD 1/1/9 Part 1, New Zealand Defence Policy - Talks and Arrangements With Allied Nations 1965-1966

196 Draft 'Review of New Zealand Defence policy up to 1970', January 1965, MoD 1/1/2 Part 1
} 
Australia and the UK were not New Zealand's ultimate security guarantors. The US had shown a consistent lack of interest in Malaysia's security and the Gulf of Tonkin Incident had increased their focus on Vietnam, an area of limited British interest. Despite a decade of SEATO planning and the experience of the Second World War, the United States was still, in operational terms, a distant ally. The challenge for New Zealand was avoiding being dragged awkwardly into two simultaneous conflicts led by different allies. The review highlighted this dilemma:

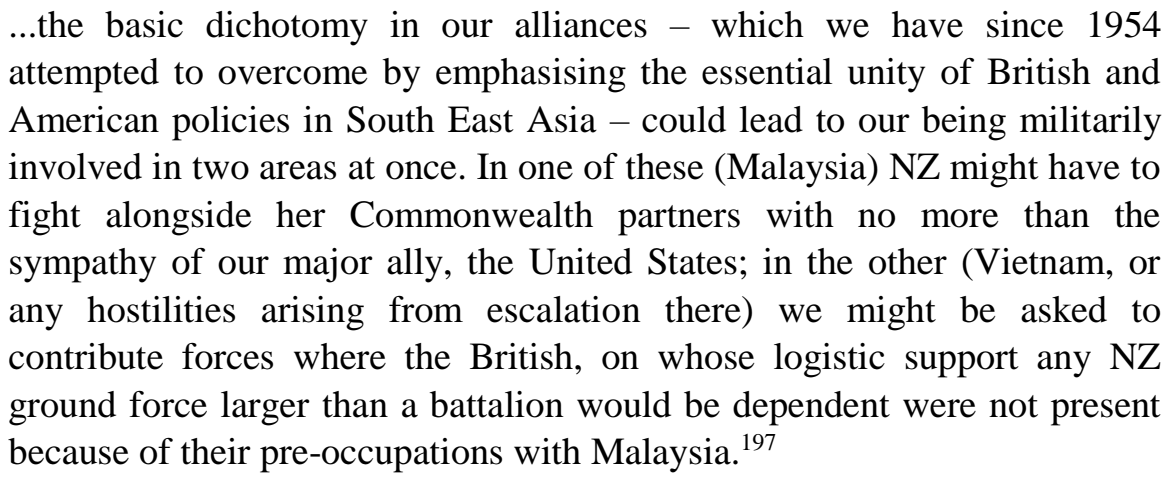

The challenges would be deciding which of these two conflicts should receive the full weight of New Zealand's limited military means, how New Zealand should equip its forces for these conflicts, and how to prepare for the longer term threat of limited war with China.

\subsection{The Vietnam Escalation ANd China}

In December 1964 US President Lyndon Johnson renewed the call for a greater New Zealand contribution to the Vietnam war. ${ }^{198}$ This was not unexpected. The aftermath of the Gulf of Tonkin Incident made it clear that the US would increase its military commitment to Vietnam and that US allies in the region would be asked to contribute combat forces to shore up South Vietnam's defence against the conventional and irregular forces of its northern neighbour. ${ }^{199}$ Holyoake's reluctant combat contribution to the Vietnam War would be New Zealand's most controversial decision of the Forward Defence era. However, for planners it was a challenge that needed to be balanced against other pressures in the region. While public opinion was obviously a major consideration of Cabinet, there were major practical, strategic, and financial considerations in deciding on the size and shape of New Zealand's participation.

\footnotetext{
197 Draft 'Review of New Zealand Defence policy up to 1970', January 1965, MoD 1/1/2 Part 1

198 Johnson to Holyoake, 12 December 1964, ABFK 19754 W5767 Box 115 JSO 147/1/1 Part 2

199 Rabel, 2005, p. 81
} 
When looking at the longer term strategic picture, planners had to question whether the American escalation would precipitate a Chinese intervention in the conflict. Planners had a highly pessimistic attitude towards the strategic outlook for South Vietnam and Laos, but thought it was unlikely, though far from impossible, that China would resort to outright belligerency in the period to $1970 .^{200}$ That is to say they considered the pressure from China to be in the form of low intensity warfare rather than limited warfare. Regardless of whether limited war with China was to occur, planners saw China as the principle destabilising actor in the region. ${ }^{201}$

There was significant internal debate amongst senior civil servants, with the majority giving cautious support for New Zealand combat participation in Vietnam. Chief among the reluctant supporters was Secretary of External Affairs, Alister McIntosh, who argued that a failure to take part might result in the withdrawal of American interest in the region. ${ }^{202}$ At the same time, he had little faith in a positive outcome in Vietnam and also warned against building too close relations with the ROC as 'sooner or later we have got to sell them down the river' to establish better relations with Beijing. ${ }^{203}$ The New Zealand Ambassador to the US, George Laking, also supported greater participation. In late 1964 he saw a significant change in US policy and recommended that New Zealand support the internationalisation of the war. ${ }^{204}$ The major opponent was Defence Secretary, Jack Hunn, but others in External Affairs and the military leadership had serious misgivings about intervention in Vietnam and the desirability of New Zealand's participation. ${ }^{205}$ The analysis in the January draft defence review shows significant concerns about the risk of the conflict escalating further, thus necessitating even greater New Zealand involvement. ${ }^{206}$

In early 1965 New Zealand had already made several civilian and non-combat military contributions to South Vietnam. A detachment of Royal New Zealand Engineers - dubbed New Zealand Army Detachment Vietnam (NEWZAD) - and a surgical team had been in South Vietnam since 1963, as the Government had resisted sending combat forces. The detachment would be increased in 1965, but in May of that year the government would agree to replace them with combat forces in the form of the 161 Battery of the Royal New

\footnotetext{
200 New Zealand Defence Policy 1965-1970', MoD 1/1/2 Vol. 2

201 'New Zealand Defence policy up to 1970', Draft A, 9 February 1965, MoD 1/1/2 Part 1

202 In the 1970s McIntosh argued he was among the most reluctant in External Affairs to get involved in Vietnam, but he also admitted pushing Holyoake into a pro-American stance: Rabel, 2005, p. 97

203 McIntosh to Corner, 15 May 1965, published in McGibbon, 1999, p. 329

204 Rabel, 2005, p. 82

205 Jack Hunn, Not Only Affairs of State, Dunmore Press, Palmerston North, 1982; and Rabel, 2005, pp. 81-90

206 Draft 'Review of New Zealand Defence policy up to 1970', January 1965, MoD 1/1/2 Part 1
} 
Zealand Artillery. ${ }^{207}$ While direct contributions to Vietnam would be small, New Zealand still declared a number of forces as part of SEATO planning for a limited war with North Vietnam or China. As of 1965 these included 3 frigates (or one cruiser and two frigates), one infantry battalion, one infantry brigade group, one medium range transport squadron, and one light bomber squadron. ${ }^{208}$ While New Zealand's commitment to the unilateral American escalation in Vietnam was limited, New Zealand remained committed to the SEATO plans for wider conflict. The American decision to act unilaterally and not utilise SEATO as the conduit (albeit still using its Manila Treaty obligations as causa belli) ${ }^{209}$ for the escalation in South Vietnam, did not seem to concern New Zealand defence planners in early 1965.

While it was clear that the US would escalate the conflict in Vietnam, less clear was whether China would intervene as it had done in the Korean conflict. There was a fear in Wellington that the American escalation would provoke direct conflict with China. If the war was extended to North Vietnam then there would be significant risks for escalation and Chinese intervention. ${ }^{210}$ Intervention was thought possible in the form of indirect action such as improving the Vietnamese People's Air Force, or through increased guerrilla activity in Laos. There was a high degree of pessimism in the report. On the future of Vietnam and Laos the report was blunt: 'from the viewpoint of New Zealand's interests the outlook in Vietnam and Laos is disturbing'. ${ }^{211}$ Those countries were considered militarily important for the defence of Thailand and a US failure in Vietnam would be disastrous to Thai morale and the credibility of American and SEATO guarantees. Thailand was the only SEATO member on the South East Asian mainland and thus was crucial to the maintenance of the alliance. This placed New Zealand in a 'painful dilemma of defence policy'. ${ }^{212}$ New Zealand had a shortage of suitable forces and was reluctant to provide more than token support for American activities in Vietnam. Yet a political settlement that favoured the communist states would cause increased instability. The most feared possibilities were the hostilities envisioned in SEATO Plan 6 (a significant attack by North Vietnam on the rest of

\footnotetext{
207 Rabel, 2005, p. 101

208 'New Zealand Defence 1965-1970', February 1965, MoD 1/1/2 Part 1

209 Fenton, 2012, p. 223

210 Draft 'Review of New Zealand Defence policy up to 1970', January 1965, MoD 1/1/2 Part 1

211 Draft 'Review of New Zealand Defence policy up to 1970', January 1965, MoD 1/1/2 Part 1

212 Draft 'Review of New Zealand Defence policy up to 1970', January 1965, MoD 1/1/2 Part 1
} 
Indochina), ${ }^{213}$ Plan 7 (a major insurgency in South Vietnam), or a limited, high intensity war with China along the lines of SEATO Plan $4 .^{214}$

While limited war was the unlikely worst case scenario, the Ministry of Defence believed that China would continue to exert a significant amount of political pressure on South East Asia over the next five years. China's nuclear test in 1964 would be exploited to its full and there was little faith that Western nuclear guarantees would be given much credence in Asian capitals. However, its nuclear and conventional capabilities would not be advanced to the point China could wage 'general war.'215 The pressure would be applied in the form of subversion and support for insurgent movements, and China was seen as unlikely to seek to initiate a limited war in South East Asia. ${ }^{216}$ However, limited war was possible through an accident or miscalculation.

China's already formidable military capabilities will also increase substantially by 1970, although not to the point where she would be capable of engaging in general war. She is unlikely to seek to initiate a limited war in South East Asia. It is clear however that in the long term Communist China will remain the greatest threat to the security of New Zealand and Australia. ${ }^{217}$

Pressure from China was not likely, in the view of New Zealand officials, to be affected by Sino-Soviet relations. The Sino-Soviet split was thought by the Ministry to be confirmed as tensions had continued after Brezhnev's replacement of Khrushchev as Soviet leader. ${ }^{218}$ Moscow was seen as treading carefully at the time but its level of influence on Chinese behaviour in South East Asia was seen as extremely limited. Beijing and Moscow were competing for influence in the region and the Ministry thought Moscow would not be able to moderate China's behaviour. Therefore, the Chinese would not 'be deterred from politicomilitary adventures on a scale below the point at which their own national security might be endangered by US counter-action'. ${ }^{219}$ In this view China had significant room to destabilise South East Asia without worrying about American response or Russian disapproval. In this sense the Sino-Soviet split had no real effect on New Zealand's security perspective. The communist world was no longer seen as monolithic but with New Zealand's security

\footnotetext{
213 Pearson, 1989, pp. 71-72

214 Draft 'Review of New Zealand Defence policy up to 1970', January 1965, MoD 1/1/2 Part 1

215 'New Zealand Defence 1965-1970', February 1965, MoD 1/1/2 Part 1

216 'New Zealand Defence 1965-1970', February 1965, MoD 1/1/2 Part 1

217 'New Zealand Defence 1965-1970', February 1965, MoD 1/1/2 Part 1

218 'New Zealand Defence 1965-1970', February 1965, MoD 1/1/2 Part 1

219 Draft 'Review of New Zealand Defence policy up to 1970', January 1965, MoD 1/1/2 Part 1
} 
interests so heavily focused on South East Asia, the Chinese threat was pre-eminent and Beijing's disagreement with Moscow made little difference.

The bleak pictures painted by New Zealand officials in 1965 were not limited to the areas around Vietnam. China had become influential in the other parts of Asia as planners saw increasing levels of instability in the wider region. Pakistan had effectively removed itself from SEATO and developed a close relationship with China as a counterweight to India. However, India had not recovered from its defeat by China in the war of 1962 and had not been able to establish itself as an alternative leader of Asia. Cambodia was becoming increasingly anti-Western and an alliance with China was possible depending on events in Vietnam. ${ }^{220}$

\subsection{The Effect of AlLies}

As the smallest of the Western powers with interests in South East Asia, New Zealand was completely reliant on its allies to maintain its presence in South East Asia. Cooperation was therefore necessary but New Zealand's small size meant it was particularly susceptible to differing interests and approaches amongst its allies. The complex web of defence relationships - SEATO, ANZAM, ANZUS, CSR - did not make it easy to reach agreement on a course of action. Differing relationships had differing benefits and problems. The defence review had to try to predict the future actions of all the major allies and how to best place New Zealand within that alliance structure to serve its interests.

In 1965 New Zealand was still more involved with Commonwealth defence commitments than with SEATO. Planning with the US outside of SEATO was limited. ${ }^{221}$ However, this does not mean that the Commonwealth was considered of the greatest strategic importance. The Ministry thought ANZUS was the agreement that guaranteed New Zealand security but it did not provide New Zealand and Australia any additional input in American defence planning. The January draft noted the problem of the detached American attitude.

ANZUS military planning has in recent years been dormant only, and four power planning (with the United Kingdom) has never become a working reality. By and large we are left to our bilateral contacts to obtain anything more that the American thinking fed into the SEATO planning machine... From the American point of view, ANZUS is simply one of the chain of alliances, of varying strength and reliability, that the United States

\footnotetext{
${ }^{220}$ Draft 'Review of New Zealand Defence policy up to 1970', January 1965, MoD 1/1/2 Part 1

${ }^{221}$ Draft 'Review of New Zealand Defence policy up to 1970', January 1965, MoD 1/1/2 Part 1
} 
maintains around the world... ...the ANZUS link is valuable and important to NZ simply because it exists, but we cannot take it as either an unqualified underwriting of security or (at this time at least) as the instrument of working out a detailed basis of defence cooperation with the Americans. ${ }^{222}$

Unlike ANZUS, SEATO was, despite its limitations, a forum for defence cooperation with the United States. Yet, by the mid-1960s SEATO had its problems. Its importance came from the fact it was the structure the Americans preferred to use to consult and cooperate with allies likely to contribute to a South East Asian war. However, the organisation was suffering due to the unofficial defection of France (due to disagreements over American policy) and Pakistan (due to closer relations with China). SEATO was facing the difficulty of being a military alliance largely made up of Western countries from outside the region, something that did not square with anti-colonial sentiment. Despite these problems, it was still useful to New Zealand as it both legitimised the Western military presence in the region and brought the UK and US together for the containment of China.

The rather rickety and unreal political superstructure of economic and cultural projects erected over the fundamental military guarantees in the Treaty should not obscure the usefulness of the latter. Despite the security problems within SEATO, it remains the one place in which all the allies with whom NZ would be fighting on the mainland of South East Asia are undertaking at least partial joint preparation. ${ }^{223}$

While New Zealand's interests were most closely aligned to those of Australia, the review makes several complaints about Canberra's attitudes and approaches. Australia was in a similar but not identical position to New Zealand. It was also reliant on British and American presence in South East Asia to maintain Forward Defence and it also had to balance its close but uncertain relationship with the UK against building an active defence relationship with the less familiar but more powerful United States. While the basic issues were similar, Australia's greater proximity to South East Asia made threats seem more acute to Canberra than they may have seemed to Wellington. At the same time New Zealand officials did not think the Australians had come to terms with the possibility of having to fight on two fronts at once. ${ }^{224}$ Australia was still committed to only making one major war fighting effort in the region. A major problem for better trans-Tasman defence cooperation

\footnotetext{
222 Draft 'Review of New Zealand Defence policy up to 1970', January 1965, MoD 1/1/2 Part 1

223 Draft 'Review of New Zealand Defence policy up to 1970', January 1965, MoD 1/1/2 Part 1

224 Draft 'Review of New Zealand Defence policy up to 1970', January 1965, MoD 1/1/2 Part 1
} 
was Australia's earlier and greater adoption of American military equipment and methods. ${ }^{225}$ However, even this did not translate into significantly greater planning opportunities for Australia with the US.

\subsection{BaLANCING THE TWO CONFLICTS}

While it may have been possible for Australia to fight in two parts of the region at once, for Wellington planners it was clear New Zealand could only make a genuine contribution to one conflict at a time. This posed the question as to whether a conflict originating from Indonesia or North Vietnam would be the priority for New Zealand forces and whether allies should be informed of that decision prior to major hostilities breaking out. ${ }^{226}$ The Joint Intelligence Committee was more pointed in its assessment than the Ministry of Defence which did not make a clear preference in the January draft. The JIC considered the Confrontation likely to continue but not last as long as the threat from China.

Our present preoccupation with the problems brought about by Indonesian confrontation undoubtedly justify a concentration of effort in the short term on this area. It is likely that confrontation activity will continue and increase in the period [to 1970], and we must be prepared for it to continue. It is, however... essentially adventurism, and could be called off if circumstances changed inside Indonesia. The long-term threat to the security of New Zealand presented by the emergence of Communist China will... undoubtedly remain with us for a long time. ${ }^{227}$

By the end of February, the Ministry had come to a conclusion on the respective weights of these threats in an updated draft with China dominating the threat profile in the longer term.

...the major and continuing threat to New Zealand's national interests will remain the ambitions of Communist China, and this is even more clearly the case in the long-term beyond 1970... The general slow deterioration in the stability and security of the South-East Asian area during the next five years is likely to lead to the increasing involvement of New Zealand in commitments ranging from further token contributions to participation in a major limited war with China. The most substantial problem in the shortterm, however, is posed by Indonesian confrontation against Malaysia.... ${ }^{228}$

Since the initiative and tempo of activity are in Indonesian hands, there is a real possibility that the Commonwealth may be required to sustain indefinitely a level of military effort which will place great strains on our

\footnotetext{
225 Draft 'Review of New Zealand Defence policy up to 1970', January 1965, MoD 1/1/2 Part 1

226 Draft 'Review of New Zealand Defence policy up to 1970', January 1965, MoD 1/1/2 Part 1

227 Chairman, JIC, for file, 8 February 1965, MoD 1/1/2 Part 1

228 'New Zealand Defence 1965-1970', February 1965, MoD 1/1/2 Part 1
} 
resolution and resources and seriously complicate the long term preparation of defences against Chinese pressures. ${ }^{229}$

The JIC had made the call that Indonesia was the bigger short-term problem, but that this may have a negative effect on New Zealand's ability to both organise its military forces and position itself amongst its allies for the best defence against the longer-term threat of war with China. The Indonesian threat kept Britain involved in the region but it also meant a potentially perpetual state of low intensity conflict with Indonesia and the accompanying threat of escalation.

The ultimate guarantor of NZ's security is privately and publicly recognised to be the United States; yet apart from SEATO planning our defence coordination with the Americans has barely developed. Similarly, it is a political fact of life (although the process is one which our interests require NZ should attempt [sic] to slow down as long as possible) that British interest and power in South East Asia will steadily decline; yet the Malaysian crisis has temporarily reversed this historical process, and indeed if NZ is involved in war during the period [to 1970] it could well be in conjunction with the British and not with the United States. ${ }^{230}$ (original emphasis)

Confrontation also created wider problems. Poor relations with Indonesia were beginning to have an effect on New Zealand's ability to operate in the region. The South China Sea was becoming increasingly unfriendly and a block on New Zealand's air/sea routes. Warships and aircraft were already having to go around Indonesia and increased hostilities would pose a significant challenge to control of air and sea communication to the area. ${ }^{231}$

\subsection{Threat to the New Zealand Area}

Even though the threat of New Zealand being drawn into one or two major conflicts in Asia was growing, the threat to the New Zealand area was seen as decreasing through the decline in likelihood of a global conflict. Even in a 'general war' - a global war involving both the superpowers, or a similar level conflict involving other powers - the direct threat to New Zealand was still considered slight. A small number of submarines laying mines or attacking surface ships was the worst the Joint Intelligence Committee expected. Missile firing submarines were likely to be reserved for higher value targets than the New Zealand area. Attacks from surface ships, aircraft, and land forces were considered impossible while allied

\footnotetext{
229 'New Zealand Defence 1965-1970', February 1965, MoD 1/1/2 Part 1

230 Draft 'Review of New Zealand Defence policy up to 1970', January 1965, MoD 1/1/2 Part 1

231 'New Zealand Defence 1965-1970', February 1965, MoD 1/1/2 Part 1
} 
nations controlled the sea approaches to New Zealand. In a limited (regional high intensity) conflict with Indonesia or China only submarine attacks were considered possible but even they were still extremely unlikely. ${ }^{232}$

[The] increased possibility of New Zealand being actively engaged with its allies in war with Indonesia and Communist China within the next five years does not, however, entail any apparent change in the nature of the military threat to New Zealand in the period to 1970. Neither China or Indonesia will have the means to wage general war in that time. In limited war, distance and lack of the necessary means, either alone or together, would prevent Indonesia or Communist China from making a direct attack upon New Zealand itself. ${ }^{233}$

ICBM attacks were considered feasible but extremely unlikely. There was an outside possibility that Indonesia could acquire long range aircraft in this time period but the risk of attack was again considered to be extremely low. ${ }^{234}$ Given this low likelihood, the Ministry placed little importance on homeland defence. The force structure that was recommended by the review would focus on making the best use of New Zealand resources for conflicts in Asia and not at home.

\subsection{EqUIPPING THE THREE SERVICES}

With the strategic picture and potential threats described, the review had to build a programme to re-equip New Zealand's forces to match the strategic vision that had been agreed upon. The review was predicated on the assumptions that alone New Zealand was not capable of repelling an invasion from a major power; that the cost of modern weapons systems meant that New Zealand was only capable of fulfilling certain roles and equipping itself for certain missions; that New Zealand's forces were so close to the minimum level viable that any decrease in the size of certain capabilities could force the complete elimination of an entire service; and that defence capabilities should focus on those that would be useful in the kind of hostilities that New Zealand was envisioned participating in. ${ }^{235}$ A limited war in South East Asia was the greatest likely danger but it was certain that New Zealand would receive calls to supply forces for lower intensity conflicts and peacekeeping. This meant that New Zealand needed to reshape its forces so that those

\footnotetext{
232 N.D Anderson, Sec, CoS Committee to Sec JIC, MoD 1/1/2 Part 1, 16 February 1965

233 Draft 'Review of New Zealand Defence policy up to 1970', January 1965, MoD 1/1/2 Part 1

${ }^{234}$ G.H. Duncum (Sec JIC) for file, 18 February 1965; N.D Anderson (Sec CoSC) to Duncum, 16 February 1965, MoD 1/1/2, Review of Defence Policy

235 Draft 'Review of New Zealand Defence policy up to 1970', January 1965, MoD 1/1/2 Part 1
} 
requests could be met without harming their ability to respond to a major conflict. ${ }^{236}$ The three services prepared their own reports detailing their needs and these were brought together by the Defence Council.

The establishment of a combined Ministry of Defence was designed to remove much of the conflict between the services, but this did not mean that the services lost their individual identities, nor did it mean that their forces could be built from scratch. Much of this process was a re-evaluation of the upgrade programme that had already begun in 1962. Like the strategic problems, the equipment problems were divided into short and long term categories. The weight to be placed on these depended on how serious the immediate strategic challenges were to become. There were significant deficiencies that needed to be addressed if a limited war was to occur in the next five years. If weight was to be placed on the longer-term, then emphasis needed to be on creating lower levels of capability which could be built on for a conflict that emerged past $1970 .^{237}$ The combined process still drew complaints from the individual services. The Navy ${ }^{238}$ and the Air Force ${ }^{239}$ felt their needs had not been adequately addressed. Despite their complaints, the process would involve the procurement of advanced ships and aircraft, some of which would be still in service at the turn of the $21^{\text {st }}$ Century.

One of the goals of the review was improving the New Zealand logistics capacity to make it less reliant on the British. The acquisition of a logistics support ship that could carry stores was considered necessary to speed up the deployment time of the Army. Extra support would have to come from the US or Australia. ${ }^{240}$ However, New Zealand was struggling with the increasing cost of buying into the Australian logistical system. ${ }^{241}$ New Zealand's isolation from the theatre of conflict stressed resources, as planners had to balance combat capabilities with the need for a reliable logistical system that was sustainable as British involvement in the region shrank.

By the mid-1960s New Zealand's military equipment was under significant pressure from the need for growth and rapid technological change bringing rapid obsolescence. The RNZAF was particularly outdated. During the early 1960s the air force was still operating

\footnotetext{
236 'Size and Shape of New Zealand Forces by 1970', 24 March 1965, MoD 1/1/2 Part 1

237 'Shape and Size of New Zealand Forces by 1970', Annex to COS(65)48, MoD 1/1/2 Part 1

238 Washbourn to CoDef Staff, 16 March 1965, MoD 1/1/2 Part 1

239 Morrison, CoAS to CoDS, 11 May 1965, MoD 1/1/2 Part 1

240 New Zealand Defence 1965-1970', February 1965, MoD 1/1/2 Part 1

${ }^{241}$ Draft 'Review of New Zealand Defence policy up to 1970', January 1965, MoD 1/1/2 Part 1
} 
de Havilland Vampires and Short Sunderlands which were already obsolete. The RNZAF was the last remaining user of the Sunderland which was a 1930s design. The English Electric Canberra bombers were still useful and it was planned to keep them in service until $1971 / 2{ }^{242}$ During the early 1960s the transport role had been provided by DC-6s acquired from a defunct Australian airline, Handley Page Hastings, and Bristol Freighters. During the 1960s the air force received new helicopters, transport planes, long range patrol, and strike aircraft. The new purchases would primarily be of American aircraft. Three Lockheed C130Hs were purchased in $1965^{243}$ and the Lockheed P3 Orions arrived in 1966 replacing Short Sunderlands. Confrontation had meant the temporary retention of the DC-6s and the Hastings. A further two C-130Hs were already expected to be ordered as the Bristol Freighters no longer met the requirements for close air support in jungle conditions. ${ }^{244}$ By the time of the 1965 review the remaining major purchase yet to be decided upon was the replacement of the Vampires. The Chief of the Air Staff, Air Vice Marshal I.G. Morrison, advocated the General Dynamics F-111 Aardvark to replace the Vampires and Canberras but accepted that it would be fiscally infeasible until prices fell after the aircraft went into mass production. $^{245}$

The navy was experiencing significant problems with the shift from a blue water force of six Loch-class frigates and one cruiser to a modern all-frigate fleet. The replacement programme had begun in the mid-1950s and had suffered long delays. This meant that the navy was predicting that it would have a 3-month period between 1966-1967 where it would have only two modern frigates available, putting it in breach of its SEATO declarations. ${ }^{246}$ The, then, three frigate programme was not sufficient to replace the outgoing ships. To fill this need the RNZN recommended leasing a fourth frigate from the Royal Navy and ordering a permanent Leander-class replacement. ${ }^{247}$ The longer term goal was an operational fleet of 6 Leander class ships and 6 coastal patrol/mine countermeasure vessels. ${ }^{248}$ The Defence Council agreed to order a fourth frigate with a leased ship in the interim, but it did not agree to the six frigate goal. Other capital items agreed to by the

\footnotetext{
242 'Defence Review: RNZAF Size and Shape', 22 February 1965, MoD 1/1/2 Part 1. The Canberras were withdrawn in 1970.

243 Three arrived in 1965 and a further two in 1969.

244 'Defence Review: RNZAF Size and Shape', 22 February 1965, MoD 1/1/2 Part 1

245 Morrison to CoDS and SecDef, 4 October 1965, MoD 1/1/2 Part 2

246 'Comments on the Size and Shape of the Navy', February 1965, MoD 1/1/2 Part 1

247 While the HMS Blackpool arrived in 1966 and its replacement, the HMNZS Canterbury in 1971, the RNZN never achieved its goal of returning to a 6 frigate fleet.

248 'Comments on the Size and Shape of the Navy', February 1965, MoD 1/1/2 Part 1
} 
Council included four minesweepers (rather than the six requested), a replenishment ship, improvements in logistical lift capacity, a new survey tender and research vessel, weapons for the Wasp helicopters, and the completion of works projects. ${ }^{249}$ The Chief of the Naval Staff, Rear Admiral R. E. Washbourn, protested at what he saw as the effective reduction of the Navy's capabilities, describing a four frigate fleet as 'minimum' and six frigates as 'highly desirable'. 250

The army was to continue with similar main components: a ground force contribution to the CSR; a field force comprised of a Combat Brigade Group and a Logistic Support Group designed for major operations in South East Asia and both supported in New Zealand by a Reserve Brigade Group; a small unit for Service with UN peacekeeping forces; and a static force for command, training, and administration of the army. The strength of the force was expected as follows: $:^{251}$

\begin{tabular}{|c|c|c|c|}
\hline \multirow{2}{*}{$\begin{array}{l}\text { Strategic Reserve } \\
\text { Field Force }\end{array}$} & & $\underline{\text { Regular }}$ & Territorial \\
\hline & & 1275 & \\
\hline & Combat Brigade Group & 868 & 5344 \\
\hline & Logistic Support Group & 1150 & 2420 \\
\hline & Reserve Brigade Group & 54 & 3080 \\
\hline UN Ready Force & & 3 & 137 \\
\hline Static Force & & 3000 & 19 \\
\hline Total & & 6350 & 11000 \\
\hline
\end{tabular}

These numbers represented an increase of 100 in the regular force and 1000 in the territorial force. $^{252}$ The UN force was new. The goal was to create a design that allowed the rapid enlargement and deployment of the field force in an emergency.

The army was also in the middle of a long term purchasing programme which had started in 1958. The review identified a number of areas for further development. The army was to receive new helicopters (as part of RNZAF purchases), new equipment for training in New Zealand (armoured vehicles, transport, engineering equipment, radios, and weapons), the replacement of obsolete and worn out equipment, the development of war reserves, and capital projects to improve accommodation. The significant problem for the army was less obsolescence as a shortage of professional manpower. The reintroduction of Compulsory

\footnotetext{
249 'Shape and Size of New Zealand Forces by 1970', Annex to COS(65)48, MoD 1/1/2 Part 1

250 Washbourn to CoDef Staff, 16 March 1965, MoD 1/1/2 Part 1

251 'Shape and Size of New Zealand Forces by 1970', Annex to COS(65)48, MoD 1/1/2 Part 1

252 'Shape and Size of New Zealand Forces by 1970', Annex to COS(65)48, MoD 1/1/2 Part 1
} 
Military Training had meant no shortages for the territorial force but the government was committed to only forward deploying full-time volunteers. While the army was confident it could meet its manpower goals by the time new equipment arrived in 1967, its regular manpower situation in 1965 'could only be described as unsatisfactory'. ${ }^{253}$ Recruitment would have to be stepped up and the current purchasing programme expanded to be completed in 1967 rather than 1968 as had originally been planned.

The upgrades requested by the three services were the result of the increased threat of war in the short term but also due to the pressures of the rapid technological changes that were occurring in the 1960s. World War Two-era frigates, 1950s fighters, 1930s patrol planes, and a motley array of transport craft were no longer acceptable. The attempt at combined planning had achieved a blueprint for the future development of the armed services, despite complaints from the RNZAF and the RNZN that they were being under-equipped. However, the review process, and its expression of heightened fear of Indonesia and China, expanded and accelerated the existing procurement programmes rather than called for radical change. While completed in only a few months, the recommendation of the review still had two significant obstacles to overcome: the desires of the Secretary of Defence and the opposition of Treasury.

\subsection{Personal Assessment by the Secretary of Defence}

Jack Hunn was appointed as the first secretary of the new Ministry of Defence. He had been a senior public servant for some time and had already led organisations including the Ministry of Maori Affairs, Internal Affairs, and the Public Service Commission. Hunn took the position reluctantly as he was concerned that coordinating the three services would not involve the freedom he had experienced running other departments. ${ }^{254}$ Hunn admired the Canadian model ${ }^{255}$ which was moving toward a single service integration during the early 1960s, but this was not completed until $1968 .^{256}$ This reform was an economising measure by Lester Pearson's Liberal Government which went much further than the defence reforms of Holyoake's government. The amalgamation of New Zealand's Air, Navy, and Army departments made the new Secretary of Defence the most powerful civil servant in charge of

\footnotetext{
253 'Shape and Size of New Zealand Forces by 1970', Annex to COS(65)48, MoD 1/1/2 Part 1

254 Jack Kent Hunn, Not Only Affairs of State (Palmerston North: Dunmore Press, 1982). p. 162

255 Ian Templeton, 'Defence Review is Expected to be "Eggless Cake", Auckland Star, 7 April 1966

256 Geoffrey D.T. Shaw, 'The Canadian Armed Forces and Unification', Defence Analysis, Vol. 17, No. 2, p. 160
} 
the military but, unlike his counterpart in Ottawa, Hunn still had to contend with the comparative independence of the services over other government agencies. Hunn's challenge to the existing organisational structure would put him odds with the Chiefs of Staff on both organisational views and on analytical grounds that centred on differing perspectives on China.

Unlike many other senior officials of the time, Hunn was far less convinced of the need for intervention in the conflicts of South East Asia. In April 1964 he warned of the danger of New Zealand becoming too involved in the conflicts of Asia, pointing to decolonisation rather than communist ideology as the primary drivers of these conflicts. ${ }^{257}$ In March 1965, Hunn offered his own view of the challenges for New Zealand's security and an outline for reforming the services in a way that met those challenges given rising costs. It called for slow but radical reform and integration of all three services to meet the challenge faced by China's rising militarily strength. Hunn's views came from a longer term perspective than the official analysis. That perspective was as optimistic about Chinese technological development as it was pessimistic about China's territorial ambitions.

...A retaliatory strike against New Zealand by air or submarine would at the moment be within the capability of Russia alone and consequently improbable, as she would hardly be disposed to administer it... Ones sees China acquiring the same competence, perhaps within ten years, and having no scruples about using it. Without [an] radar early warning device or anti-missile missiles, our only defence could be maritime air and strike air. Even those would be so limited in such circumstances as to be almost negligible. The risk of a retaliatory strike is one we probably have to accept and try to ward off by our political posture rather than by military counter measures.

In the end New Zealand may have to face an invasion by China herself and with auspices much more in favour of China than they were for Japan 23 years ago. This would be the ultimate test of our defences. The long sea and air haul would render an assault on New Zealand unlikely until China had taken over Indonesia as she seems destined to do. By the time China is ready to think about Australia and New Zealand she may be a regenerate "peaceful co-existence" nation like Russia. She may no longer want to export Communism for its own sake. Such a change of heart would, however, afford us little consolation as she will be forced to expand for other reasons. China's prime needs are land, rice and oil. With her vast population proliferating at the regions in the course of time. Sooner or later she will look covetously at Australia and New Zealand. Then a process of intimidation may be our first warning - a demand perhaps for abolition of the "white Australia policy" as an offence against "human rights", and for

257 Hunn, SecDef, to MinDef, 24 April 1964, MoD 1/1/6 Part 1 
free immigration into Australia and New Zealand. If political and psychological tactics fail she may rattle her rockets preparatory to fullscale invasion by air and sea. ${ }^{258}$

These comments came from a desire to reform the three services into a smaller number of combined services such as an air fleet arm, air force paratroopers, or marines. ${ }^{259}$ However, Hunn's strategic assumption was that the future for South East Asia would be one of Chinese communist domination and that New Zealand needed to refocus its defence posture to one that was of use in home defence - to the extent that would be possible - and would be useful to our allies in the meantime. New Zealand's effort would go into defending the approaches to the country until the US could come to New Zealand's defence. This vision was opposed to the Forward Defence model which prepared for a limited war while trying to make those forces as useful in lower intensity operations. Hunn's vision of China was one of an expansionist power, but that expansionism was not necessarily driven by its communist ideology. Hunn saw China as needing to expand in search of resources as he believed Japan had done and as likely to pose a significant threat through its own necessity.

Hunn's views were not supported by other leaders in the defence community. There was opposition to the reorganisation of the services but also to Hunn's strategic logic. The Chief of the Defence Staff, Lieutenant General Leonard W. Thornton, tried to counter Hunn's reasoning and calls for reform. ${ }^{260}$ Thornton pointed out China's military capacity was still many years from developing the capability to take South East Asia directly and then subduing Australia. Such an invasion of the region would result in major conflicts with the SEATO powers including the US and UK. If China prevailed in such a conflict, then no amount of domestic effort would prevent New Zealand's domination. The logic of Hunn's limited home defence was lost if the US was already unwilling or unable to come to New Zealand's rescue. Thornton saw little need for a change of approach unless the alliance structures of ANZAM, SEATO, and ANZUS broke down irrevocably and the US retreated to isolationist policies. Prudence was on the side of preparation for fighting the limited war that would defend the countries between New Zealand and China while maintaining the assistance of the allied powers.

Maintaining the Forward Defence model would preserve the three-service model which would come up against significant institutional inertia as each service tried to maintain its

\footnotetext{
258 Hunn, SecDef to MinDef, 18 March 1965, MoD 1/1/2 Part 1

259 Hunn, SecDef to MinDef, 18 March 1965, MoD 1/1/2 Part 1

260 Thornton to MinDef, 18 April 1965, MoD 1/1/2 Part 1
} 
own independence. As Thornton was preparing to defend the existing order, he was being attacked by the Chief of Naval Staff, Rear Admiral R. E. Washbourn, for favouring the Army and the Air Force in the current review. ${ }^{261}$ The three services worked together to preserve their own independence which they put to use in arguing for a greater share of the defence vote. Hunn had tried to bolster his argument for service integration with a very different strategic vision to that which had already been developed by his own ministry. That vision was unlikely to win favour with the chiefs or with a naturally cautious government that was unlikely to want to renegotiate New Zealand's position in the major alliances that had been so carefully built over the previous decade. Despite offering a radically different approach to meeting New Zealand's threats, Hunn's alternative demonstrates the level of consensus that existed on the role of China as New Zealand's core long-term threat and general level of pessimism on China's future power that existed in 1965.

\subsection{FINANCE}

While the review process was quick to highlight extra needs for the armed forces, the Cabinet and the Treasury proved less convinced by the need for urgency. New Zealand's military spending was limited not just by the country's small size but also by its particularly small industrial base and currency controls. All major acquisitions had to be imported with precious foreign exchange that became increasingly difficult to spend as American equipment replaced British sourced items. Forward Defence was also a drain on foreign currency through the need to house large numbers of personnel and their families overseas. Increases in defence spending would not just mean the need to economise on other government spending, it would mean the reduction in imports generally. Greater defence imports would have to be offset by reductions in the importation of consumer and capital goods. Treasury therefore needed to be convinced that the extra spending was warranted and Cabinet needed to be convinced that increasing the defence share of imports would be politically acceptable to the public. The reluctance of both to commit to the full recommendations of the review would slow the review process into 1966.

The Defence Council understood the difficulty of financing new and American sourced products. It argued that new methods of foreign spending needed to be found rather than adjusting military expenditure year to year based on the amount of foreign currency available. It suggested that the Export-Import Bank be utilised when procuring American

261 Washbourn to CoDef Staff, 16 March 1965, MoD 1/1/2 Part 1 
equipment and further investigations on how to cut the cost of forces stationed abroad. ${ }^{262}$ Cabinet did exactly what Phipps had warned against at the beginning of the review process and deferred several decisions on the defence programme.

Treasury was sceptical of the need for the size of the project and warned that any increase in spending for the armed services would necessitate more borrowing or heavy cuts in domestic spending and imports. Treasury was already concerned about a balance of payments crisis and increases in foreign spending over the rest of the 1960s. Any increase in future spending would have to be placed in the context of economic headwinds such as British entry into the European Common Market without special dispensation for New Zealand exports. ${ }^{263}$ Defence had asked for $£ 244.5$ million in spending for the period $1965 / 70$, but Treasury proposed two options cutting this to either $£ 204$ or $£ 210$ million. ${ }^{264}$

The Ministry of Defence reacted strongly to the Treasury analysis claiming it would leave the armed forces unbalanced, unable to get forces speedily into action and sustain them appropriately, and fail to improve the effectiveness of New Zealand's forces over the next two or three years. ${ }^{265}$ It warned that Cabinet needed to make decisions quickly and not simply cut parts of the project as any significant cost cutting would require a complete redesign of the programme to maintain the best value for money. ${ }^{266}$ A rescheduling of priorities would assist in overcoming the short term 'special problems' of 1965-1967. ${ }^{267}$ Hunn later warned the Cabinet Defence Committee that any reduction from the $£ 244.5 \mathrm{~m}$ would be effectively reducing New Zealand's overall defence capability and that if less money was allocated then New Zealand would have to reorganise its forces to more modest capabilities which would be hard to explain to allies and the public. ${ }^{268}$

\subsection{The TACTICAL LeVel}

The drafts of the defence review identified China as the primary strategic threat but said little about China's forces or how it was expected to fight. Much of this detail went into the 'The NZ Army Concept of Operations 1966-70' document which was adopted in early 1966. It identified the 'Chinese Communist Army' (now referred to as the People's Liberation

\footnotetext{
262 'New Zealand Defence 1965-1970', February 1965, MoD 1/1/2 Part 1

263 R. N. Davis, Sec Treasury to Min Finance, 30 September 1965, MoD 1/1/2 Vol. 2

264 R. N. Davis, Sec Treasury to Min Finance, 30 September 1965, MoD 1/1/2 Vol. 2

265 'Suggested statement to Defence Committee', 6 October 1965, MoD 1/1/2 Vol. 2

266 'Suggested statement to Defence Committee', 6 October 1965, MoD 1/1/2 Vol. 2

267 DefSec to MinDef, 5 October 1965, MoD 1/1/2 Vol. 2

268 DefSec to Defence Committee of Cabinet, 15 December 1965, MoD 1/1/2 Vol. 2
} 
Army) as the primary adversary. ${ }^{269}$ The concept of operations assumed New Zealand forces would be involved in low intensity to limited warfare which involved the PLA and People's Army of Vietnam (PAVN). It considered, like the strategic-level reports, that deliberate overt aggression was unlikely but if it did occur, the communist military aim would be the conquest or neutralisation and then peaceful takeover of South Vietnam, Laos, Cambodia, Thailand and possibly Burma. Subversion through guerrilla warfare was expected to be the primary means of attack but this could be supplemented with conventional forces causing the environment to approach limited war. However, the PLA would be limited by the terrain which would be difficult for tracked vehicles and thus necessitate a heavy reliance on infantry. Such a scenario was still considered unlikely as insurgency alone would be highly effective and could be supplemented with small numbers of conventional forces without risking a blatant aggression. ${ }^{270}$

The PAVN was considered by New Zealand Army officials to be reliant on the PLA for logistic support and any combined operations would be conducted in accordance with PLA doctrine. It was considered unlikely that the PAVN would initiate open aggression without Chinese participation, but if it did then the North Vietnamese would employ similar tactics to what was expected from the PLA. ${ }^{271}$ The geographic limitations on the use of armour were noted alongside the fact that the PLA was adequately equipped with artillery. A portion of that artillery had greater ranges than New Zealand's equivalent weapons. Nevertheless, the PLA was primarily an infantry force with several technical limitations but an abundance of manpower.

Probably the greatest weaknesses of the CCA are obsolescence of equipment, production and procurement problems, tenuous logistic support and a weak economic, scientific, and technical base. In tactical operations there is an apparent inflexibility of its command organisation at the lower levels. However, there is some evidence that this being resolved. Its greatest asset lies in its huge resources of manpower and consequent freedom from the tactical restraints imposed on Western Armies by the need to conserve manpower. ${ }^{272}$

The concept of operations shows a reasonable understanding of the irregular and semiregular forms of warfare practised by Communist China and North Vietnam. The individual Chinese or Vietnamese soldier was described as having several positive attributes and

\footnotetext{
269 'The NZ Army Concept of Operations 1966-70 (Provisional)', February 1966, MoD 1/1/2 Vol. 2

270 'The NZ Army Concept of Operations 1966-70 (Provisional)', February 1966, MoD 1/1/2 Vol. 2

271 'The NZ Army Concept of Operations 1966-70 (Provisional)', February 1966, MoD 1/1/2 Vol. 2

272 'The NZ Army Concept of Operations 1966-70 (Provisional)', February 1966, MoD 1/1/2 Vol. 2
} 
considered a formidable opponent. They were described as tough, hardy, fatalistic, able to survive on a meagre diet, dedicated to communism, and having great mobility on foot. The communist armies were described generally as having the advantage of familiar geography, huge manpower resources, a history of success in battle, and having the initiative in choosing the area of operations. These advantages were balanced against the lack of reliable logistics, limited air and naval support, and a lack of initiative amongst the rank and file. ${ }^{273}$ The authors made reference to and demonstrated a basic knowledge of Mao's writing on military matters and theories on guerrilla warfare. An example of this is the authors' belief that enemy intelligence would be thorough due to the close contact between the enemy and the civilian population. ${ }^{274}$

Indonesia's confrontation with Malaysia was also addressed in the concept of operations. ${ }^{275}$ The concept of operations identified Indonesia's goals as being the fragmentation of Malaysia, the removal of Western influence, and the assertion of itself as the leader of anticolonialist 'New Emerging Forces'. The New Zealand Army considered overt aggression by Indonesia to be unlikely, but confrontation still posed some risk of escalation. ${ }^{276}$ This seems to show a change in attitude from the intelligence assessments from the previous year which were more concerned about the chance of escalation. Yet this new view seems to have been based on a low estimate of Indonesian military ability, rather than from a belief that Indonesian policy had or would change.

The Indonesians have failed to achieve two essential prerequisites for an insurgency campaign - sufficient support from indigenous people and the establishment of secure bases within Sarawak/Sabah. Operations have been marked by a lack of coordination, poor planning, faulty intelligence, inadequate training and sheer inefficiency. Changes in the command structure have not produced the desired improvements, and the Indonesians seem not to be learning from their various mistakes. ${ }^{277}$

Indonesia was not expected to change its aims even if there were a change of government, but its tactics could change if it were presented with a viable alternative to confrontation. Until then subversion would continue with occasional shallow cross-border raids with forces of company strength and deeper raids of platoon strength.

\footnotetext{
273 'The NZ Army Concept of Operations 1966-70 (Provisional)', February 1966, MoD 1/1/2 Vol. 2

274 'The NZ Army Concept of Operations 1966-70 (Provisional)', February 1966, MoD 1/1/2 Vol. 2

275 'The NZ Army Concept of Operations 1966-70 (Provisional)', February 1966, MoD 1/1/2 Vol. 2

276 The possibility of escalation was a handwritten comment on the provisional report. 'The NZ Army Concept of Operations 1966-70 (Provisional)', February 1966, MoD 1/1/2 Vol. 2

277 'The NZ Army Concept of Operations 1966-70 (Provisional)', February 1966, MoD 1/1/2 Vol. 2
} 
The concept of operations mirrored the strategic level analysis on the expected level of New Zealand's participation in South East Asia and the overall level of risk of war. It was a reminder that despite the small risk of limited war before 1970, New Zealand was likely to see greater involvement in the 'military as well as the political problems of the area'. ${ }^{278}$ The expectation of planners was that New Zealand would come into some form of military conflict with China even if that conflict was most likely to be at a low level. There seems to have been little expectation of a conflict that involved North Vietnam and not Communist China.

\subsection{CONCLUSION}

The defence establishment's internal debates of 1965 demonstrated the centrality of China as the dominant long-term threat to New Zealand's interests. China's lack of naval power, long range bombers, or ICBMs meant China was still not a significant threat to New Zealand's own shores, but it was believed that the threat would grow over time. For the moment China was seen as a threat to South East Asia, a danger that would grow as China developed. The confrontation with Indonesia was the more immediate problem. New Zealand could not afford the loss of Malaysia but officials felt Indonesia's hostility would eventually dissipate leaving China the most significant threat to New Zealand's core interest of defending the emerging states of South East Asia as they made up the land approach to Australia. The view of China coming from the Ministry and the chiefs was one of a state attempting to maximise its power; China was thought to be seeking to displace Western influence in South East Asia and slowly obtaining the capacity to do so. The only significant debate was between Hunn, who thought there was little New Zealand could do to contain China's growing power, and the chiefs, who thought Forward Defence was effective in ensuring Anglo-American guarantees for the region.

The review process was initiated by the creation of the Ministry of Defence but accelerated by problems of early 1965. What is striking about the review process of 1965 is the confidence of the assessments and the structured approach to strategic problems. Distinct categories of potential armed conflict were defined and New Zealand's defence commitments provided a structure for making spending choices for the country's modest spending capacity. SEATO was not an ideal alliance, but it provided the basis of practical defence engagement with the United States and war planning in case of a significant 278 'The NZ Army Concept of Operations 1966-70 (Provisional)', February 1966, MoD 1/1/2 Vol. 2 
emergency. Meanwhile ANZAM and the AMDA provided day-to-day planning and logistics for New Zealand. New Zealand was reliant on these arrangements with allies to provide any form of military assistance to the region. However, any capability gap in these arrangements then provided an opportunity for New Zealand to fill the need.

The year 1965 was a major pinch point between threat and capability. In January 1965 there was serious concern that a rapid escalation in Vietnam or Borneo might require the full utilisation of New Zealand's military resources. This combination of threats from North Vietnam and Indonesia highlighted the obsolescence of much of New Zealand's military hardware. The RNZAF was still flying pre-World War II maritime patrol aircraft. Its Vampire fighters and Canberra bombers were also becoming antiquated at a time when military technology was developing rapidly. The RNZN was also suffering a transition to a smaller number of more capable but also more expensive ships. The purchase of the first Iroquois helicopters occurred in April 1965 and while operated by the RNZAF, the Army would be the main beneficiaries of these aircraft. ${ }^{279}$ These were expensive upgrades, some of which had already been planned by the start of the review, but the review highlighted their pressing need. The replacement of capital equipment on this scale would not be seen again. Many of the new aircraft - the Iroquois, the Hercules, and the Orions - would continue to be used well into the $21^{\text {st }}$ century.

The power of the Treasury should not be ignored. The opposition from Treasury to greater spending was significant. Defence spending was difficult for New Zealand due to the lack of domestic manufacturing possibilities and therefore the need for foreign exchange. The shift to American produced aircraft exacerbated this problem. The Government had a strong incentive to ensure that the defence establishment could not run away with its budget. It might be possible to argue that the sense of elevated threat that permeated the Review of Defence Policy 1966 was self-serving: an attempt by the Ministry and the chiefs to push the Government for new greater spending and greater upgrades. However, even if this were the case, this card could only be played once. As will be explored below, the brass found it impossible to argue for continued heavy spending once the strategic picture changed. While always on the lookout for savings, the Government did accept the strategic picture developed by officials in the review process and did provide much of the spending demanded by the defence establishment.

279 Damien Marc Fenton, A False Sense of Security: The Force Structure of the New Zealand Army 1946-1978, CSS, Wellington, 1998, p. 153 
Despite the decision to commit combat troops to Vietnam, the perceived risk that New Zealand would need to place significant forces into a war zone declined during 1965 . The possibility of limited war came to be thought of by officials as unlikely until at least 1970 . However, lower intensity warfare was thought to be a serious, ongoing, and worsening problem. China was thought to support guerrilla groups across the region in order to destabilise Western leaning governments. SEATO and Commonwealth forces were trying to both deter China from embarking on a high intensity conflict in the region and also stamp out low intensity conflict by local groups directed or inspired by Beijing. SEATO alliance's protection of South East Asia was therefore seen less as a steel dome and more as a colander. A flood of Chinese forces could be defended against but Chinese power could still seep through in the form of low intensity conflict. The war in Vietnam, while not directly connected to New Zealand's core interests in Malaysia and Singapore, was seen by officials in 1965 as part of that wider containment of China.

The final version of the review that was released publicly expunged much of the detail of the risks and problems faced by defence officials. However, the identification of China as New Zealand's primary long term source of threat remained. Despite the achievement of the review and the upgrades that it helped usher in, the strategic situation would soon change significantly and the level of uncertainty would continue to increase. Soon the commitment of London and Washington to South East Asia would weaken and so too would Wellington's view of Chinese aspirations and capabilities. The entire basis of containment would break down and this would reshape, but not break, the concept of Forward Defence. 


\section{Shifting Ends And MeAns and Perpetual ReVIeW}

\subsection{INTRODUCTION}

The Review of Defence Policy 1966 was intended to map out the future of New Zealand's defence policy for five years but Cabinet failed to provide the level of funding required to implement it, leading the review process to recommence less than two years after the 1966 review was released. New Zealand's allies were also changing their positions. Meanwhile the Cultural Revolution would have a significant impact on the New Zealand Government's perceptions of China and its policy of containment, an issue which will be explored in depth in the next chapter. This chapter will examine the defence review process of 1968 which failed to produce a public statement of defence policy. Nevertheless, the review process would see New Zealand through a major transformation of its defence role in Asia and the assumptions that underpinned that role.

The combined influences of British withdrawal, American military difficulty in Vietnam, and the Cultural Revolution in China, were precipitating the erosion of both the means and ends of New Zealand's China strategy. By 1968 the Vietnam War was, for New Zealand officials, no longer part of a policy aimed at the wider containment of China, but had become a serious problem in itself. Neither side was likely to achieve victory if the US remained committed to the conflict, but in 1968 American and New Zealand public support for the war began to slide and American military engagement in South East Asia became politically and fiscally unsustainable. The US decision to act in Vietnam independently from SEATO had mortally wounded the alliance, which was already suffering from the effective withdrawal of Pakistan and France. However, it would take several years before Wellington's faith in SEATO had eroded completely.

In 1966 the UK confirmed that it would no longer maintain a major or permanent military presence east of Aden after 1971. This meant the UK would leave its bases in Malaysia and Singapore which were utilised by New Zealand and Australia. This decision left New Zealand and Australia with only the shaky support of the US as the only remaining major Western power committed to containing China in South East Asia. New Zealand and Australia would have to decide whether it was feasible or desirable to continue to forward deploy forces to South East Asia. This led to a re-examination of New Zealand's goals in South East Asia and a shift in New Zealand's commitment to containment began to occur. 
New Zealand's Forward Defence policy, came to be justified as a means to support regional relationships rather than being focused primarily on containing China. These changes were part of a reassessment of New Zealand's position on China which allowed for greater engagement with Beijing.

By the late 1960s, the Vietnam War had become for New Zealand policymakers the dominant problem in the region. The United States' losses in the Vietnam War and their withdrawal from mainland South East Asia would undermine the means of New Zealand's Forward Defence strategy. While in 1965 officials still saw the war as an extension of Beijing's ambitions, by 1968 they would come to view it as a separate problem. In their view, the war was expected to continue into the 1970s, but they saw a lower risk of it escalating into a region-wide conflict involving China. By 1968 defence planners were looking beyond Vietnam to the kinds of conflicts that New Zealand might take part in after Vietnam, and those views were beginning to look quite different from the assumptions that had driven the Review of Defence Policy 1966.

All of these issues would drive the new defence review process which was never completed as events in Asia began to outpace the ability of the bureaucracy to complete the review process. As a result, New Zealand strategy lost a degree of coherence which was evident in the 1966 review. Things just became much more difficult with the declining reliance on the UK and the US. The review would begin rehashing the same old argument about Forward Defence but end with the whole strategy in tatters.

\subsubsection{Vietnam and SEATO}

While New Zealand had gained little direct support from the Americans through SEATO, the alliance was still the organisation through which the US had engaged South East Asia. Washington's decision to act outside the alliance in its intervention in Vietnam also undermined SEATO's usefulness to New Zealand. The alliance had provided a useful framework to design New Zealand force structure. Its complex war plans allowed for New Zealand to play a specific role that reflected its resources. This meant New Zealand did not have to provide a complete military apparatus but could provide elements for the bigger containment machine. The CSR provided an extra, day-to-day, framework which kept New Zealand operating at the bases in Malaysia and Singapore. The loss of the British support for the CSR and SEATO's marginalisation meant that New Zealand no longer had obvious roles to fulfil in its Forward Defence mission. Resources had to be redistributed to fill gaps 
caused by the British withdrawal and new capabilities had to be justified. The defence establishment could no longer use New Zealand's SEATO commitments as a guide for its force structure. This combined with the British withdrawal meant decisions had to be made about the direction and extent of New Zealand participation in Asian security.

\subsubsection{Restarting the Review Process}

Cabinet's refusal to fund the individual elements of the Review of Defence Policy 1966 brought about the need for a fresh review of defence spending less than two years after the previous review had been completed. This new review would have to accept that spending would need to be reduced from what had been expected in the 1966 review. When compared to that previous review, there was a distinct change in the arguments made for expanding and maintaining military capabilities. The dreaded loss of support for containment policies from the US and UK made it difficult for the New Zealand defence establishment to argue for increases in funding needed to complete the upgrades that had been planned through the decade. Treasury was increasingly hostile to financial requests for defence purposes and Cabinet became equally reluctant to allow any increase in the defence share of government expenditure or GNP. With the marginalisation of SEATO there were no longer convenient structures and missions that New Zealand capabilities could be designed to meet. Previously New Zealand had a clear threat in the form of Chinese expansionism, a clear planning structure in the form of SEATO, an operational structure through the CSR, a domestic political consensus on defence, and an ultimate security guarantee in the form of ANZUS. The late 1960s would see the breakdown of all of those elements with the exception of ANZUS. The increasing unpopularity of the Vietnam War and the rapidly changing international political situation, made Cabinet uneasy about increasing defence spending.

These political and financial challenges came as the New Zealand military had to adjust to the increased demands of the British withdrawal. This need to do more with less sparked a debate between External Affairs and the Ministry of Defence as to whether New Zealand should continue to maintain forces in Malaysia/Singapore past 1971. External Affairs felt that New Zealand's effort should be switched to Vietnam, whereas the Defence Council did not want to lose its grip on its foreign bases. The debate would be won by Defence which eventually secured a place in South East Asia past 1971. Yet by 1969 the rationales for those bases and for the Vietnam War had both worn thin. New Zealand and Australia would remain in Malaysia/Singapore without the active support of a major Western power. Yet this 
presence would no longer attempt to be part of the containment of China. New strategies to manage China would have to be found.

\title{
3.2 INTER-REVIEW ASSESSMENTS
}

The Cultural Revolution increased uncertainty in the region. Defence and External Affairs were informed about what was occurring in China by the New Zealand Commission in Hong Kong, but officials remained uncertain as to how to respond and on its impact on strategic policy. A year into the revolution, in mid-1967, the Defence Planning Committee could not see it having an effect on Chinese strategy in South East Asia.

\begin{abstract}
The main long term threat continues to stem from Communist China whose military capability is steadily increasing. The outcome of the "cultural revolution" is not yet clear but it is unlikely to affect China's external policy which is to expand communism in South East Asia by means of subversion and insurgency and to expel Western influence from the region... In our view the strategic situation... gives us little cause for optimism that New Zealand's military involvement in South East Asia will diminish. Indeed there is every likelihood that increased commitments will be expected of us. In these circumstances we see no grounds for changing the present focus of New Zealand's defence effort. ${ }^{280}$
\end{abstract}

As far the Committee was concerned, the Cultural Revolution would not change China's objectives or its methods in South East Asia and thus the need for containment would continue.

The Review of Defence Policy 1966 was underpinned by officials' belief that New Zealand's interests in South East Asia were coming under greater threat. However, at the same time, they accepted that the threat of global war between the Soviet Union and the United States had decreased since the 1961 review. $^{281}$ As a result, New Zealand's resources were concentrated on Forward Defence, with little emphasis placed on home defence. In September 1966 the Chief of Naval Staff, John O'C. Ross, challenged this view by arguing that the White Paper had underestimated the possibility of hostile submarine activity in New Zealand waters. In his view it was only a change in the political climate, rather than a change in technical capability, that would result in Soviet submarines being provided to China or Indonesia for hostile actions in the New Zealand area. While the Orions and the RNZN frigates would provide an anti-submarine capability for this eventuality, enemy

\footnotetext{
280 'Implications for New Zealand Defence Policy of the Strategic Assessment 1967-1972', Defence Planning Committee, Annex A to DPC(67)25, 20 June 1967, MoD 1/1/2 Vol 3, Review of Defence Policy

281 'Review of Defence 1965’, Appendix 2 Annex to DPC(65)58, MoD 1/1/2 Vol 2
} 
submarine activity would pose a significant mine-laying threat. Ross believed that the navy needed modern minesweepers to meet the threat of hostile submarine activity in the event of China and/or Indonesia obtaining Soviet submarines. He requested that the White Paper be amended to include an investigation of obtaining a modern mine-clearing capability. ${ }^{282}$ Ross' objections were not accepted by the Defence Council but they did record his objection in the review of home defence. ${ }^{283}$

\subsection{Singapore/Malaysia VS. VIETNAM}

\subsubsection{British Defence Review 1966}

The British Defence White Paper of 1966 would have major implications for the direction of New Zealand's defence policy. It recommended that Britain withdraw from its permanent major military presences east of Aden after $1971 .{ }^{284}$ Britain's position as a global power had been in decline since the Second World War and New Zealand officials were aware that the UK was seeking to reduce its role in Asia. ${ }^{285}$ British Prime Minister Harold Wilson wrote to Holyoake in January 1966 outlining the direction of British policy and discussions with the Americans. ${ }^{286}$ The primary focus of the British review was cost cutting. The UK was facing an escalating defence budget and a public with a growing distaste for military entanglements far from home. Harold Wilson's Labour government wanted to re-prioritise conventional arms over nuclear forces and align political commitments with military resources. This would mean significant retrenchment of overstretched British forces as defence spending had reached $7 \%$ of UK GNP. ${ }^{287}$ The Wilson government committed to capping defence spending at the $1963 / 4$ figure of $£ 2,000$ million. This would mean finding savings of $£ 400$ million by $1969 / 70$. Much of these saving would have to come from reducing Britain's overseas military commitments. Commitments east of Aden were to see the heaviest reductions but the UK was still mindful of disrupting the American alliance, its commitment to Australia and New Zealand, and its 'residual colonial territories' in the area. ${ }^{288}$

\footnotetext{
282 Ross (CoNS) to SecDef, 22 September 1966, MoD 1/1/2 Vol 3, Review of Defence Policy

283 'Home Defence Policy for the New Zealand Area', 23 September 1966, MoD 1/1/2 Vol 3, Review of Defence Policy

284 This is occasionally also referred to as 'East of Suez' but Aden is accurate. Nevertheless, a presence would (and did) remain in some areas such as Hong Kong.

285 For discussions between NZ and UK over the issue of British withdrawal see: MoD 1/1/9 Vol. 1-13

286 Wilson to Holyoake, c. 13 January 1966, MoD 1/1/9 Part 1 Talks and Arrangements with Allied Nations

287 Claire Taylor, 'A Brief Guide to Previous British Defence Reviews', Report SN/IA/5714, House of Commons Library, 19 October 2010, http://www.parliament.uk/briefing-papers/SN05714.pdf

288 Annex to DPS(66)4, MoD 1-1-9 1 Talks With Allies 1965-1966
} 
During 1966 New Zealand officials were deeply concerned about the effect of British withdrawal on New Zealand's ability to maintain Forward Defence. The loss of the Malaysian and Singaporean bases would render SEATO's Plan 4 (countering a Chinese invasion of South East Asia) inoperable for New Zealand. New Zealand supported the Australian view that Australian bases would be insufficient to maintain the Plan 4 timetable or the wider Commonwealth defence concepts. New Zealand would not be able to deploy forces into the area under the proposed timetable, unless heavy peacetime stockpiling was undertaken in Thailand or the Philippines. Such stockpiling was seen as economically and politically difficult. ${ }^{289}$ In the wake of the British review it seemed that the loss of the bases in Malaysia/Singapore was highly likely and this would mean an end to Forward Defence and New Zealand's commitment to SEATO plans and timetables would have to be reconsidered. ${ }^{290}$

Over the course of 1966 through to 1968 officials had to assess whether it was feasible for New Zealand to continue to place its forces in South East Asia. New Zealand needed to decide whether it should continue to deploy peacetime forces to Malaysia and Singapore beyond the point they could be supported by British forces. In practical terms it would depend on whether Malaysia and Singapore would continue to want to host Western forces on their territory and whether Australia wished to continue its presence. A New Zealand presence was not considered possible or even desirable without Australia. Yet officials still had a strong preference for Forward Defence. New Zealand took a back seat in discussions over the possibility of basing UK and Australian forces in northern Australia as an alternative to Forward Defence, despite British and Australian requests for New Zealand involvement. ${ }^{291}$ While those discussions took place, an Australasian-only presence in South East Asia became more feasible as perceptions of the Chinese threat loosened over the same period. As the containment of China became less of a priority for the Forward Defence project, the need for British support became less critical.

The British signalling of their intention to withdraw was one of several factors that were undermining the New Zealand 1966 review only months after it was completed. The Vietnam War had intensified, Confrontation had ended and China's nuclear capabilities had

\footnotetext{
289 'AS, NZ, and UK Defence Discussion to be held in Canberra, February 1966: Background Information for CDS', MoD 1/1/9 Part 1, Talks with Allies 1965-1966

290 'AS, NZ, and UK Defence Discussion to be held in Canberra, February 1966: Background Information for CDS', MoD 1/1/9 Part 1, Talks with Allies 1965-1966

${ }^{291}$ CoDS to NZHC Canberra, MoD 1/1/9 Part 1, Talks with Allies 1965-1966
} 
improved. In light of these developments Thornton recommended the Joint Intelligence Committee update their position on the strategic situation as part of an effort to review defence needs annually. ${ }^{292}$ By mid-1967 a fresh review of defence was looking necessary but was not possible as Wellington was still waiting for a final decision on the future role of British forces in Asia. That was expected in July and Wellington would wait for Australian and American reactions before making any decisions. ${ }^{293}$

The Chiefs of Staff issued a fresh opinion in September once confirmation arrived that Britain would withdraw entirely from its bases in Singapore/Malaysia by the mid-1970s. ${ }^{294}$ This report looked at New Zealand's options given the loss of British resources. It noted that Britain remained committed to SEATO and the Anglo-Malaysian Defence Agreement but the nature, size, and timing, of its commitment would change radically. The report predicted that from April 1968 the UK would start failing to meet its previous SEATO commitments and British logistic and administrative support for New Zealand's contributions to SEATO plans would decline. At some point between 1968 and 1973 New Zealand would no longer be able to provide its contributions 'in the cheapest possible way'. ${ }^{295}$

The Chiefs of Staff favoured a continued presence in Asia. When giving their reasoning, the chiefs continued to assume that the Government would look to continue Forward Defence provided that Australia continued its support for the policy. ${ }^{296}$ They also assumed conscription would not be introduced for overseas service. Threats to Australia were argued to be the same as for New Zealand. The location of the effort in Malaysia and Singapore was also considered important. In September 1967 the chiefs saw control of the Malaysian peninsula as the strategically valuable point between the dangers of China and Indonesia. Western forces in Malaysia/Singapore were seen as providing a bulkhead preventing Chinese communism from advancing south to Indonesia. However, this is a somewhat strained argument as geographical contiguousness was not a prerequisite for the spread of communism and the Indonesian military's purge of communists had effectively destroyed

\footnotetext{
292 Thornton (CoDS) to other Chiefs of Staff, 12 January 1967, MoD 1/1/2 Vol 3, Review of Defence Policy

${ }^{293}$ Minutes of the Chiefs of Staff Committee Meeting, COS/M(67)24, 23 June 1967, MoD 1/1/2 Vol 3 , Review of Defence Policy

294 'New Zealand Military Presence in South East Asia', Annex to COS(67)101, 26 September 1967, MoD 1/1/2 Vol 3, Review of Defence Policy

295 'New Zealand Military Presence in South East Asia', Annex to COS(67)101, 26 September 1967, MoD 1/1/2 Vol 3, Review of Defence Policy

296 'New Zealand Military Presence in South East Asia', Annex to COS(67)101, 26 September 1967, MoD 1/1/2 Vol 3, Review of Defence Policy
} 
the PKI. ${ }^{297}$ Regardless, the continued instability of the region still allowed for sudden and dramatic changes to the political landscape.

In general terms a threat to Australian security is not perceptibly different from a threat to New Zealand, and Australian strategy is thus for all practical purposes indistinguishable from our own. It is of vital importance to Australia that Indonesia should be contained if it declines to become a friendly trading neighbour. It is of importance to Australia that Indonesia should remain in friendly hands and be protected from Communist pressures from the North. To this extent at least, the land bridge (Singapore and Malaysia) has considerable importance to Australia. ${ }^{298}$

Unlike their British counterparts, New Zealand defence officials were still pessimistic about Indonesia's susceptibility to communism. The need for American support was made stronger by the confirmation of the British withdrawal but this need, in New Zealand eyes, was based on the threat from China rather than Indonesia. Keeping the Americans involved in South East Asia was now crucial to the objective of containment.

Australia and New Zealand do not have the resources to counter-balance the Chicom threat in South East Asia, and need to have an absolute guarantee of support from a major power or powers. ${ }^{299}$

The problem was that while the UK had directly supported the Australasian effort in Malaysia/Singapore, the Americans were at arm's length. The US effort in the region was in Vietnam and while the US approved of the Commonwealth effort it was not committed to providing material support for bases in Malaysia/Singapore. The Chiefs of Staff understood that while they saw their interests as being largely in sync with Australia's, the interests of the UK and US were different. However, these differences were manageable provided that those interests overlapped with those of Australasia.

The objectives of the United States and the United Kingdom in South East Asia are not identical one with the other nor with Australasian objectives, but this is not significant so long as Allied strategy encompasses our requirements. ${ }^{300}$

American commitment to the containment of China was seen by the chiefs as encompassing Australasian interests but they also believed Australasian commitments would not make any

\footnotetext{
297 Subritzky, 2000, p. 176

298 'New Zealand Military Presence in South East Asia', Annex to COS(67)101, 26 September 1967, MoD 1/1/2 Vol 3, Review of Defence Policy

299 'New Zealand Military Presence in South East Asia', Annex to COS(67)101, 26 September 1967, MoD 1/1/2 Vol 3, Review of Defence Policy

300 'New Zealand Military Presence in South East Asia', Annex to COS(67)101, 26 September 1967, MoD 1/1/2 Vol 3, Review of Defence Policy
} 
practical difference to American military objectives. Australasian military commitment suited American objectives of demonstrating international support for its policies. In the eyes of the New Zealand chiefs, the complete abandonment of the Asian mainland by the Commonwealth would not be received well in Washington. They believed the US desired the 'southern flank' to be protected 'for the re-assurance of Thailand, but also for the deterrence of [Chinese] encroachment into Burma and the "insulation" of Indonesia'. ${ }^{301}$ A military vacuum would be considered undesirable and a withdrawal, even to Vietnam, would not be supported by the Americans. This argument has an element of wishful thinking as New Zealand officials had expressed repeatedly the difficulty in obtaining American interest in Malaysia/Singapore.

Singapore and Malaysia were thought to consider the US an unsuitable substitute for British security and did not expect New Zealand and Australia to withdraw along with the UK. The hope in Wellington was that regional associations would develop into collective security agreements but it was acknowledged that this would take many years. ${ }^{302}$ There was hope that New Zealand and Australia could form a bridge between South East Asia and the US and that an Australasian commitment may encourage sustained British interest in the region. Regardless, any structures put in place by Singapore, Malaysia, New Zealand, and Australia were considered insufficient to contain China without US or British support.

While convinced New Zealand should attempt to continue its Forward Defence policy past the British withdrawal, the chiefs were less convinced of the practicality of New Zealand maintaining its own forward deployment. The timetable of British withdrawal looked as though the New Zealand military would face significant challenges from 1969 onward. In September 1967 the chiefs believed that by April 1969 the loss of British logistical support would mean the New Zealand Battalion would no longer be able to deploy on SEATO operations according to existing plans as the battalion's readiness would slide from 11 days to four months. By April 1970 the British Fleet Far East would no longer provide stocks for the support of RNZN frigates and British command and administrative services for the battalion would have gone. By April 1971 the British Fleet Far East might no longer be able

\footnotetext{
301 'New Zealand Military Presence in South East Asia', Annex to COS(67)101, 26 September 1967, MoD 1/1/2 Vol 3, Review of Defence Policy

302 'New Zealand Military Presence in South East Asia', Annex to COS(67)101, 26 September 1967, MoD 1/1/2 Vol 3, Review of Defence Policy
} 
to support, service, or repair RNZN vessels. ${ }^{303}$ Additional administrative elements were possible but would increase costs. However, sufficient logistical support to enable operations outside Singapore and Malaysia were thought to be beyond New Zealand's capability. Increased cooperation with Australia could have allowed for peacetime and low intensity counter insurgency operations, but wider operations would require American logistical support. Australia had nearly completed an agreement with the US for logistical support along the lines of what it received for Vietnam operations and it was expected New Zealand could do the same. Increasing New Zealand's interoperability with the US and Australia would assist in this effort. Thus New Zealand's continued presence in South East Asia was dependent on a number of variables: Australian cooperation; Malaysian and Singaporean acceptance of Australasian forces stationed on their territory for operations around the region; the agreement of all parties that Australasian guarantees of security were provided only via regional security agreements in which the US was a major partner; and that the US would provide logistical support to Australasian forces operating in the wider region or on major operations around Malaysia or Singapore. ${ }^{304}$

If these conditions could not be met then, in the opinion of the chiefs, forces should be redeployed to American bases in the region. The most obvious destination would be Vietnam but this would create difficulties for meeting calls for collective defence in other parts of the region. Thailand was also a possibility but New Zealand's obligations to Thailand under SEATO Plan 4 or Plan 8 would be executed with difficulty from Thailand itself. ${ }^{305}$ This did not mean that a complete shift to Vietnam would be either cheaper or provide a sustainable increase in New Zealand forces to that conflict. Troops in Vietnam were paid substantially more than those in Malaysia and were replaced twice as often. ${ }^{306}$ Australia and the US were expected to welcome the prospect of a New Zealand battalion to assist the Australian Task Force which was hampered by a lack of infantry. However, this would require an annual turnover of 1,400 men which was four times the replacement rate of the New Zealand Army in South East Asia at the time. Transferring the remaining 580 men based at Terendak, Malaysia would not be enough. Those men could have been

303 'New Zealand Military Presence in South East Asia', Annex to COS(67)101, 26 September 1967, MoD 1/1/2 Vol 3, Review of Defence Policy

304 'New Zealand Military Presence in South East Asia', Annex to COS(67)101, 26 September 1967, MoD 1/1/2 Vol 3, Review of Defence Policy

305 'New Zealand Military Presence in South East Asia', Annex to COS(67)101, 26 September 1967, MoD 1/1/2 Vol 3, Review of Defence Policy

306 MoD comments on unnamed External Affairs paper of 11 September 1967, MoD 1/1/2 Vol 3, Review of Defence Policy 
transferred to form a second supplemented infantry company for Vietnam but on expected 'wastage rates' (through sickness and battle causalities) this would not be able to be sustained for more than two years without changes to recruitment rates or the manpower ceiling. However, an SAS element could be provided continuously via New Zealand. ${ }^{307}$ Despite the possibility of a transfer to Vietnam the first preference for the chiefs was the maintenance of a presence in Malaysia and Singapore. In their view forces should only be transferred to Vietnam as the ability to support those elements in Malaysia and Singapore was lost. No new forces should be added to Vietnam if it were to imperil the Commonwealth Strategic Reserve. However, keeping the force on the peninsular would take significant negotiations with allies and thus the recommendation was that all options be left open for as long as possible. ${ }^{308}$

External Affairs was much more sceptical of the value of keeping forces in Malaysia and Singapore after the loss of British support. It saw little benefit to a New Zealand military presence on the peninsula and proposed that the infantry there be utilised to create 'a more effective force' in Vietnam. ${ }^{309}$ Air and naval forces could remain in Singapore until services to support them were lost. External Affairs did not know what the American or Australian attitudes would be, but thought the US was unlikely to give material support to New Zealand's continued presence in Malaysia and Singapore at the expense of greater involvement in Vietnam. It considered the Commonwealth Strategic Reserve to be an outdated concept while Defence still saw merit in it even without substantial British involvement. The opinion of Defence on the External Affairs assessment was to try and avoid making any moves until it was clear whether new support for New Zealand's presence on the peninsular could be found.

Confirmation of the British withdrawal was also confirmation that the containment strategy that underpinned New Zealand's military role in Asia was unsustainable. Confrontation with Indonesia had ended but that did not mean Malaysia and Singapore were secure, nor was there any guarantee that Australasian forces would be welcome there in the future. With the costs of transferring New Zealand's forces to Vietnam high, the political desirability of such a change low, and little desire for a complete abandonment of Forward Defence, there was a

\footnotetext{
307 'New Zealand Military Presence in South East Asia', Annex to COS(67)101, 26 September 1967, MoD 1/1/2 Vol 3, Review of Defence Policy

308 'New Zealand Military Presence in South East Asia', Annex to COS(67)101, 26 September 1967, MoD 1/1/2 Vol 3, Review of Defence Policy

${ }^{309}$ MoD comments on unnamed External Affairs paper of 11 September 1967, MoD 1/1/2 Vol 3, Review of Defence Policy
} 
high incentive to keep New Zealand forces in Malaysia and Singapore if possible. The question remained whether New Zealand and Australia could realistically deter China without significant British support.

\subsection{A FRESH REVIEW}

Final decisions on New Zealand's place in Singapore/Malaysia were not rushed, but the need to resolve the issue gained fresh impetus with the announcement that the UK would withdraw from Singapore/Malaysia by $1971 .{ }^{310}$ An interim decision on New Zealand's role would not come until November 1968, ${ }^{311}$ but in the meantime another difficult review of defence policy would be required to manage costs and the changing environment. In February 1968, Holyoake and the Minister of Defence David Thomson ${ }^{312}$ both acknowledged that, while the principles of the 1966 review remained valid, the British withdrawal and the pressure on overseas earnings meant that the objectives of the review needed reassessment. ${ }^{313}$

While there was a working assumption by officials and the Government that the strategic situation had not changed, their description of the problems faced in South East Asia had evolved considerably. The Vietnam conflict was now identified by the Ministry of Defence as the 'greatest threat to security in East Asia'. ${ }^{314}$ The future of the conflict remained uncertain as (probably in reference to the Tet Offence) 'North Vietnam forces [had] recovered the military initiative' ${ }^{315}$

With large Soviet and Communist China support [the North Vietnamese and Viet Cong] seem determined to press this major test of a war of national liberation to a conclusion on the battlefield. ${ }^{316}$

This signalled a change in attitude to the war from an extension of or proxy for Chinese power in South East Asia to a war of national liberation as Hunn had characterised it over

\footnotetext{
${ }^{310}$ Memo for Cabinet, 8 February 1968, MoD 1/1/1 Vol 1, New Zealand Defence Policy - Policy - General, 1961-1968

311 Press statement by Keith Holyoake, 20 November 1968, MoD 1/1/2 Vol 5, Review of Defence Policy

312 David Thomson took over from Dean Eyre as Minister of Defence in December 1966. He would remain as minister until Jack Marshall became Prime Minister in February 1972. Allan McCready took on the role of Minister of Defence until National's defeat at the end of 1972.

313 Draft memo for Defence Council, c. February 1968, MoD 1/1/2 Vol 3, Review of Defence Policy

314 Draft memo for Defence Council, c. February 1968, MoD 1/1/2 Vol 3, Review of Defence Policy

315 Draft memo for Defence Council, c. February 1968, MoD 1/1/2 Vol 3, Review of Defence Policy

316 Draft memo for Defence Council, c. February 1968, MoD 1/1/2 Vol 3, Review of Defence Policy
} 
two years earlier. While hostility from China was seen as having increased since the 1966 review, the risk of war was now a problem subordinate to the situation in Vietnam.

Since [the 1966 review] Communist China has pursued policies designed to eliminate other great power interests and to promote regimes similar, or at least acceptable to it, in South East Asia. Such policies seem certain to continue. Communist China [is] likely to promote its influence by political means, including subversion, and by support for "revolutionary wars". To underwrite these policies, Peking seems intent on developing nuclear as well as conventional capabilities. Though unlikely, there will always be the possibility that Communist China might become involved in major hostilities with the United States and its allies in South East Asia, as a result of the escalation of the war in Vietnam and less likely in Laos. New Zealand will therefore have a continuing interest in planning to meet the greatest possible requirement, New Zealand participation in a war involving major hostilities with Communist China. Since it is an unlikely contingency this should have a lesser priority than the situation in Vietnam. It would nevertheless be necessary to maintain, as a mission of the armed forces, ability to contribute in the event of major hostilities towards collective defence in South East Asia. ${ }^{317}$

This represents an uncoupling of the Vietnam War from the problem of Communist Chinese expansion argued in the 1966 review. By 1968 the Vietnam War was seen as a separate problem that was unlikely to cause a major conflict between the US and China. This report suggests the Ministry of Defence saw Vietnam as both the bigger and more immediate problem for New Zealand than the risk of a major conflict with China.

The other reason for the new review was Cabinet's reluctance to approve funding for the individual elements of the 1966 review. Defence would not have the financial resources to complete the objectives of the 1966 review. The Army Field Force upgrade programme was two years behind schedule and being complicated by rapid obsolescence. Combat aircraft to replace the Canberras and additional helicopters had yet to be purchased. Logistic support needed to be developed due to the British withdrawal. ${ }^{318}$ The Defence Council asked the Cabinet Defence Committee what changes could be made to New Zealand commitments given the financial situation. ${ }^{319}$

\footnotetext{
317 Draft memo for Defence Council, c. February 1968, MoD 1/1/2 Vol 3, Review of Defence Policy

318 SecDef to MinDef, c. January 1968, MoD 1/1/2 Vol 3, Review of Defence Policy

319 Meeting Minutes, DC(68)M.1, 10 January 1968, MoD 1/1/2 Vol 3, Review of Defence Policy
} 


\subsubsection{Rationalising the Needs and Threats}

To assist the CDC a 12-page report was put together by the Ministry of Defence. In this report China was still identified as the major strategic threat, although it was put on the same level as indigenous communist movements in South East Asia.

Instability in South East Asia, carrying risks of strategic deterioration and escalation into major hostilities must be of concern to New Zealand, since the undermining of states in the area by communist movements or the establishment of regimes subservient to a militant Communist China would pose a threat to the security and national interests of New Zealand and, even more directly, to Australia with which our long term security is indissolubly linked. ${ }^{320}$

Again it was stated that the objectives of the 1966 review had not changed, but the disconnect between China and Vietnam was noted.

In light of the strategic situation, the most pressing requirement will be the provision of combat ready forces for South Vietnam, and similar emergencies elsewhere in the area. Discussions are continuing on the implications of British withdrawal but there are advantages in attempting to maintain a modest military presence in Malaysia/Singapore. In addition we have to take account of the risk, even though unlikely, of major hostilities between Communist China and the United States and its allies. Our principal allies plan against such an eventuality and will expect New Zealand to be able to contribute to the defence of South East Asia and of its sea and air approaches. ${ }^{1321}$

In a change from previous reviews, this update of the 1966 review outlined briefly specific missions for the armed forces giving them specific priorities and outlined forces required for each mission. The four missions for the armed forces were identified in order of importance with the threat of 'major hostilities' notably dropping down on the list of priorities.

1. Most pressing requirement: the provision of combat forces for Vietnam and for similar emergencies.

2. Second most pressing requirement: the maintenance, depending on consultations and satisfactory arrangements with allies, of a small military presence in Malaysia/Singapore, at least until the British withdrawal.

3. Lesser priority: the maintenance of a capability to contribute, in the event of major hostilities, towards collective defence of South East Asia and of its sea and air approaches.

320 'Defence Review 1968', c. February 1968, MoD 1/1/2 Vol 3, Review of Defence Policy
321 'Defence Review 1968', c. February 1968, MoD 1/1/2 Vol 3, Review of Defence Policy 
4. Continuing need: the maintenance of a capability to contribute to the defence of the New Zealand area should this ever be required. ${ }^{322}$

The force designed for Vietnam and other similar emergencies was given the highest priority and New Zealand's forces needed to be shaped for this kind of conflict and be able to be sustained on operations within 'peace-time' budgets. This force would include an infantry battalion with light observation helicopters, an RNZAF force of 9 Iroquois utility helicopters and 6 Bristol Freighter medium range transports, and a naval force of 6 patrol craft. $^{323}$

The force designed for major hostilities would involve a range of operational units which could respond to a major conflict in a reasonable amount of time. These hostilities were imagined to involve countering Communist Chinese aggression in South East Asia. The forces designed for Vietnam and similar operations would provide the initial contribution to such a conflict until a larger and wider range of forces could be deployed. The initial contribution would involve a combat brigade group with an accompanying logistic support group; an RNZAF task force comprising of 10 Skyhawks, 15 Sioux and 26 Iroquois helicopters, 7 C-130 transports, and supporting units; 3 frigates with another under refit, 3 Orions forward deployed for air reconnaissance with 2 kept in New Zealand for training, 3 minesweepers forward deployed with 1 under refit, a logistics support vessel, and naval personnel to arm merchant ships. ${ }^{324}$

The defence of the New Zealand area would not require any specific extra units or facilities but would require separate planning for New Zealand conditions. ${ }^{325}$ Final decisions were still yet to be made on the military presence in Malaysia and Singapore as it still depended on forthcoming decisions by Australia and the UK. Any requirements would not be in addition to forces designed for Vietnam-style conflicts or major hostilities. ${ }^{326}$ The development of a new logistical supply chain was on going and would be heavily dependent on discussions with the US and Australia. ${ }^{327}$ Manpower would have to increase to cope with these priorities. Increases would occur over five years as new or replacement equipment was acquired.

\footnotetext{
322 'Defence Review 1968', c. February 1968, MoD 1/1/2 Vol 3, Review of Defence Policy

323 'Defence Review 1968', c. February 1968, MoD 1/1/2 Vol 3, Review of Defence Policy

324 'Defence Review 1968', c. February 1968, MoD 1/1/2 Vol 3, Review of Defence Policy

325 'Defence Review 1968', c. February 1968, MoD 1/1/2 Vol 3, Review of Defence Policy

326 'Defence Review 1968', c. February 1968, MoD 1/1/2 Vol 3, Review of Defence Policy

327 'Defence Review 1968', c. February 1968, MoD 1/1/2 Vol 3, Review of Defence Policy
} 


\begin{tabular}{|c|c|c|c|c|c|}
\hline $\begin{array}{l}\text { Manpower } \\
\text { Requirements: }\end{array}$ & & Navy & Army & Air & Total \\
\hline \multicolumn{6}{|l|}{$\begin{array}{l}\text { Counter- } \\
\text { Insurgency }\end{array}$} \\
\hline & $\begin{array}{l}\text { Deployed } \\
\text { Overseas }\end{array}$ & 181 & 1,299 & 300 & 1,780 \\
\hline & $\begin{array}{l}\text { Immediate } \\
\text { Support in NZ }\end{array}$ & 105 & 1,400 & 105 & 1,610 \\
\hline & Total & 286 & 2,699 & 405 & 3,390 \\
\hline \multicolumn{6}{|l|}{ Major Hostilities } \\
\hline & $\begin{array}{l}\text { Deployed } \\
\text { Overseas }\end{array}$ & 1,196 & 8,425 & 1,067 & 10,688 \\
\hline & $\begin{array}{l}\text { Immediate } \\
\text { Support in NZ }\end{array}$ & 791 & 2,950 & 302 & 4,043 \\
\hline & Total & 1,987 & 11,375 & 1,369 & 14,731 \\
\hline
\end{tabular}

In addition to these numbers were a small number for defence aid and ancillary national tasks, plus 12,357 other personnel for home defence bringing the total to 30,896 . Of these 16,800 would be regular servicemen, 11,170 would be non-regulars, and 2,926 civilians. This would require an increase of 2,151 regular servicemen and 75 non-regulars over five years. $^{329}$

As indicated in the previous review, major purchases would have to be made, some of which had already been ordered. For Vietnam style operations these included major equipment upgrades for the regular infantry, seven Sioux and nine Iroquois helicopters, new medium range transport aircraft, and six naval patrol boats. For 'major hostilities' upgrades would consist of major equipment for the combat brigade group and the logistic support group, four C-130 transports (two were already expected to arrive at the end of 1968), 27 observation and 30 utility helicopters, 18 Skyhawks (14 had already been ordered at this point), 2 anti-submarine warfare helicopters (one already planned for the Canterbury), a logistic support ship, a fourth frigate (tenders were already accepted), four minesweepers,

328 'Defence Review 1968', c. February 1968, MoD 1/1/2 Vol 3, Review of Defence Policy

329 'Defence Review 1968', c. February 1968, MoD 1/1/2 Vol 3, Review of Defence Policy 
two inshore survey craft, a survey vessel, four fishery protection vessels, and 20 jet trainers. $^{330}$

Under this plan defence spending would increase from \$117.25 million for the year 1969/70 to $\$ 138.1$ million for the year 1971/72 then decrease again to $\$ 127$ million for the year 1973/74. ${ }^{331}$ Thomson concluded the report by pointing to the increasing costs of maintaining the same capabilities with only limited improvements, the difficulty in making savings, and the difficulty in making reductions given the strategic environment in South East Asia. ${ }^{332}$

The Minister took the paper to Cabinet on 12 February $1968 .{ }^{333}$ There was a clear division between Thomson and his Cabinet colleagues over defence spending as the Minister was advocating for increased spending when Cabinet had repeatedly deferred spending already on approved defence projects. Holyoake had already released a statement on 8 February indicating the need for a fresh review of the 1966 white paper given the circumstances. ${ }^{334}$ Thomson, Thornton, and (Hunn's replacement as Secretary of Defence) William Hutchings were all calling for an increase in funding and for budgetary certainty. Any review could result in a freeze on acquisitions of capital equipment, including those where funding was available through United States Export/Import Bank credit arrangements. Thomson believed a new review would be a cost cutting exercise and not a proper interpretation of strategic changes. He asked Treasury to reassess its preliminary schedule of requirements for the 1968/69 financial year, as he hoped no drastic reductions would occur until after the 68/69 departmental allocations were approved. The concern of the Secretary's office (represented by RM Mullins) was that uncertainty would cause problems for New Zealand's discussions for collective security in the region. The Defence Council saw any review to be a matter of urgency which needed to be completed by the Ministry as quickly as possible.

\subsubsection{JIC(NZ)(68)3}

On 9 February the Defence Council agreed that the Ministry of Defence should begin work on an urgent review of defence policy. This would allow the Government to make decisions as soon as possible and allow it to be prepared for SEATO and ANZUS meetings that

\footnotetext{
330 'Defence Review 1968', c. February 1968, MoD 1/1/2 Vol 3, Review of Defence Policy

331 'Defence Review 1968', c. February 1968, MoD 1/1/2 Vol 3, Review of Defence Policy

332 'Defence Review 1968', c. February 1968, MoD 1/1/2 Vol 3, Review of Defence Policy

333 CabSec to SecDef, 13 February 1968, MoD 1/1/2 Vol 3, Review of Defence Policy

${ }^{334}$ Defence Council Minutes, DC/68/M7, 9 February 1968, MoD 1/1/2 Vol 3, Review of Defence Policy
} 
April. $^{335}$ The JIC quickly produced a new strategic assessment for the years '1968-73 and beyond'. ${ }^{336}$ Like previous JIC assessments, it only tried to look five years into the future. While the JIC report gave an outline for the entire Asia-Pacific, it focused separately on the fortunes of China and the Vietnam War. While acknowledging the turmoil of the Cultural Revolution, it doubted that there would be any major change in direction for Chinese policy in South East Asia. Much more would depend on the outcome of the Vietnam War which was not expected to be realised within the next five years. The Chinese would have their policies in South East Asia justified if South Vietnam was to fall, but that would only happen if the US did not maintain its support for the country. Yet, at the same time, the JIC acknowledged that war fatigue had set in and (in a prediction of the Guam Doctrine of the following year) the JIC envisioned the US would fall back to an island periphery strategy once the conflict had been resolved. The JIC did not seem to have a clear idea how the conflict in Vietnam would conclude but hinted that American political resolve could show weakness before Hanoi would be willing to compromise.

\subsubsection{Fresh Perspectives on China}

The JIC report provides the clearest picture of an official view of the Cultural Revolution and the changes occurring in China placed in a context for New Zealand defence planners.

The situation within Communist China in recent years has been dominated by the Cultural Revolution. The divisive and disruptive forces deliberately unleashed have rent the fabric of Chinese society, played havoc with the central and especially local party and government machinery, checked economic growth, and created turmoil and violence. ${ }^{337}$

The report also shows a significant change in the attitude towards China's future prospects. Its attitude is far from those expressed in 1965 which saw China as a growing power, and the JIC was now even farther from the fatalism that had been expressed by Hunn. The JIC saw a China that was unlikely to experience any significant growth and would continue to struggle with internal conflict.

We believe that the Cultural Revolution will be continued or revived in some form so long as Mao retains his influence. At his death - or even conceivably before then, if he carries his policies to the point where they jeopardise the regime's cohesion or security - his ideas will have less

\footnotetext{
335 SecDef (W. Hutchings) to Defence Council, 18 March 1968, MoD 1/1/2 Vol 3, Review of Defence Policy

336 'Strategic Assessment 1968-73 and Beyond', JIC(NZ)(68)3, February 1968, MoD 1/1/2 Vol 3, Review of Defence Policy

337 'Strategic Assessment 1968-73 and Beyond', JIC(NZ)(68)3, February 1968, MoD 1/1/2 Vol 3, Review of Defence Policy
} 
chance of prevailing against the compelling reasons for more pragmatic policies. A successor regime - which is likely in the next five years, and almost certain in the next ten - could well represent an alliance of the bureaucratic group and the more flexible army leadership. It might review many Maoist policies and, moreover, is likely to require a period in which to establish itself. While still communist, it could liberalise economic policies, especially in agriculture, and attach less importance to ideology. Such policies are likely; on the other hand others, even extremist and dogmatic policies, are possible. In any event the regime will continue to face significant problems in achieving economic progress in the face of population increases. ${ }^{338}$

The JIC saw the Cultural Revolution as being driven by Mao but, recognising his advancing age, they looked to his successors. The prediction of the rise of 'an alliance of the bureaucratic group' and the military which would consolidate itself and then initiate liberal reforms, proved accurate but on a longer time scale than was being examined by the JIC.

External policies were not expected to change considerably with the passing of Mao's influence. The Cultural Revolution had led to 'aggressive and disruptive conduct' towards China's neighbours but Beijing had still been careful not to risk war. A successor regime even a moderate one - was not seen as likely to change China's approach to South East Asia. China would still want the elimination of Western and Soviet influence in the region and want to promote regimes acceptable to it. However, the JIC did concede that Beijing could change its methods in achieving these goals. 'Pragmatism at home would probably be paralleled by more flexible policies abroad'. ${ }^{339}$ If the Vietcong was successful in uniting Vietnam under communism then Beijing could be encouraged to support revolutionary movements elsewhere but a setback would lead to a reassessment of their military doctrines.

\subsubsection{Vietnam and Limited War with China}

The JIC report was prepared in the aftermath of the Tet Offensive where the Viet Cong and NVA had demonstrated their ability to launch attacks on over 100 towns and cities across South Vietnam. ${ }^{340}$ Although the offensive was pushed back and caused significant losses for the Viet Cong, it demonstrated a failure of the US to defeat communist forces in Indo-China. While the JIC report of March 1968 did not make any direct reference to the offensive, it

\footnotetext{
338 'Strategic Assessment 1968-73 and Beyond', JIC(NZ)(68)3, February 1968, MoD 1/1/2 Vol 3, Review of Defence Policy

339 'Strategic Assessment 1968-1973 and Beyond', JIC(NZ)(68)3, March 1968, MoD 1/1/2 Vol 3, Review of Defence Policy

${ }^{340}$ For details on the US failure to predict the offensive see: James J Wirtz, The Tet Offensive: Intelligence Failure in War, Cornell University Press, Ithaca, 1991
} 
must have influenced the thinking of the committee. During the offensive the New Zealand ambassador to Washington, Frank Corner was informed of the 'shock and air of gloom' which fell over the US administration. ${ }^{341}$ Corner noted that New Zealand should prepare itself for further requests for a greater military contribution to the war and heard officials say for the first time that the US might cut its losses should South Vietnam fail to hold-up to the pressure of the offensive.

The analysis coming out of Wellington was not as grim, but by this point the JIC did believe that the Vietnam War had reached a stalemate without either side being able to defeat the other militarily. The success of South Vietnam would depend on the willingness of the US to continue the war of attrition, and skill on the part of South Vietnamese to continue pacification of the country. Hanoi was showing no sign of accepting a negotiated settlement that did not reunite the country under its control. If this were to change, then the North Vietnamese would have to be convinced their casualties were losing them the war. The South Vietnamese Government was thought to remain precarious during the next five years and would require the presence or 'ready availability of military forces'. ${ }^{342}$ Officials concluded that war was likely to continue during the next five years.

Given the stalemate in Vietnam the JIC was not confident of the stability of US policy in South East Asia. Regardless of the outcome of the 1968 US federal elections, American policy would have to take into account the 'widespread misgivings and significant opposition' to the war in Vietnam. ${ }^{343}$ The future direction could be dovish or hawkish, but US public opinion would not permit a simple withdrawal from Vietnam as it would be perceived as a communist victory. US policy for the wider region would come under much greater scrutiny in the future. The JIC believed the US would continue its containment policy to counter China's ambitions in Asia, but the JIC's alternative theory was much closer to the mark.

United States strategy could... vary significantly according to the outcome of the war in Vietnam and the domestic and political scene. We believe that, other things being equal [sic], the United States will be reluctant to become involved in any further limited war situations on the Asian

\footnotetext{
${ }^{341}$ David Dickens, 'New Zealand and the Vietnam War Official Policy Advice to the Government 1960-1972', $\mathrm{PhD}$ Thesis, Victoria University of Wellington, 1995, p.290. Original Ref: Corner to Laking, 6 February 1968, MoD 23/4/1 Vol 2

342 'Strategic Assessment 1968-1973 and Beyond', JIC(NZ)(68)3, March 1968, MoD 1/1/2 Vol 3, Review of Defence Policy

343 'Strategic Assessment 1968-1973 and Beyond', JIC(NZ)(68)3, March 1968, MoD 1/1/2 Vol 3, Review of Defence Policy
} 
mainland except in response to an overt attack upon countries with which the United States has treaty obligations. We believe further that it will seek to confine its activities to providing military equipment, training facilities and other aid designed to assist individual governments to defend themselves against insurgency and subversion. The United States will be reluctant to maintain forces on the Asian mainland and will prefer to fall back to the island bases around the rim of the Pacific Ocean. ${ }^{344}$

In a major break from previous JIC reports on this topic, this assessment did not attempt to outline the likelihood of limited war with China. This was noted in handwriting on the Ministry copy of the report ${ }^{345}$ and would prove contentious within the Defence Council. The risk of global war was still mentioned and considered unlikely. Like the assessment of a few months prior, it made a clear distinction between the war in Vietnam and the threat posed by Chinese policies, with the war no longer seen as Chinese expansionism. The JIC view of Chinese policy was now less about seeking domination and more the removal of Western and Soviet influence in South East Asia. China was still seen as a supporter and supplier of North Vietnam and the JIC believed the outcome of the conflict would still have serious ramifications for Sino-Western relations, but the Vietnam War was no longer seen as a conflict that could spill over into a major conflict between Western powers and China. This, in part, is a change which sees China behaving more like a major nuclear armed power and thus more cautious than previously assumed. South East Asia would continue to be 'unstable and exposed to subversion and insurgency'. ${ }^{346}$ Therefore it seems that the JIC had come to the implicit conclusion that the region's instability had reached an equilibrium; or to put it another way, its instability no longer threatened major hostilities. The region would continue to see violence but the perceived risk of escalation into war between the major powers had gone.

\subsubsection{Cross-Strait Relations}

The cross-strait dispute was considered stable and it was considered very unlikely that the PRC or the ROC would initiate any major conflict in the next five years. Greater democracy in Taiwan was considered possible after the death of Chiang Kai Shek but the Guomindang was likely to retain control of the island. The US would continue to provide a security

\footnotetext{
344 'Strategic Assessment 1968-1973 and Beyond', JIC(NZ)(68)3, March 1968, MoD 1/1/2 Vol 3, Review of Defence Policy

345 R. M. Mullins (Chairman of the JIC) to Defence Secretariat, 8 February 1968, MoD 1/1/2 Vol 3, Review of Defence Policy

346 'Strategic Assessment 1968-1973 and Beyond', JIC(NZ)(68)3, March 1968, MoD 1/1/2 Vol 3, Review of Defence Policy
} 
guarantee to Taiwan but no major threat was likely to emerge over the next five years. Even if such a threat did emerge, New Zealand was unlikely to be drawn into a conflict given the terms of New Zealand's security arrangements as they were then construed. ${ }^{347}$

\subsubsection{Chinese Nuclear Capabilities}

The JIC believed China would continue to develop nuclear weapons as they provided a deterrent against the United States, a claim of great power status, and increased Beijing's ability to intimidate its neighbours. The JIC believed China had already deployed MRBMs with fission warheads and a modest force of thermonuclear armed missiles would have come online by 1970 . These missiles would have a range which included Japan, the Philippines, mainland South East Asia, and northern India. Thermonuclear armed ICBMs would slowly become operational during the early 1970s and by 1975 a 'limited number' would be deployed. ${ }^{348}$ China's ability to wage nuclear war against the US would not necessarily depend on China achieving nuclear parity, ${ }^{349}$ but the JIC believed China would only use nuclear weapons if it were threatened with invasion. The military gap between China and either the US or the USSR was so wide that China would not risk a major conflict with either country. Its nuclear forces may threaten smaller neighbours but would only be used at great risk of retaliation. China's nuclear weapons development then was assumed by the JIC to be closely matched with increases in conventional forces to provide greater flexibility in its military strategy. ${ }^{350}$

\subsubsection{SEATO and ASEAN}

There was still a little faith left in SEATO by the JIC. The committee believed that the alliance would continue with the same level of activity. It was believed that the US would continue to support the alliance while still operating independently in South East Asia. However, there was more scepticism of intra-regional cooperation. There were signs of cooperation in areas other than defence. The Association of Southeast Asian Nations (ASEAN) was the most promising organisation, but was unlikely to evolve into a collective

\footnotetext{
347 'Strategic Assessment 1968-1973 and Beyond', JIC(NZ)(68)3, March 1968, MoD 1/1/2 Vol 3, Review of Defence Policy

${ }^{348}$ This proved to be something of an overestimate. The DF-5 ICBM had its first flight in 1971 but did not become operational for another decade: Federation of American Scientists, 'DF-5', http://fas.org/nuke/guide/china/icbm/df-5.htm

${ }^{349}$ Minutes of the Chiefs of Staff Committee Meeting, COS/M(67)2, 22 March 1967, MoD 1/1/2 Vol 3, Review of Defence Policy

350 'Strategic Assessment 1968-1973 and Beyond', JIC(NZ)(68)3, March 1968, MoD 1/1/2 Vol 3, Review of Defence Policy
} 
security arrangement. Regardless, no grouping of South East Asian nations would be able to 'constitute a credible defence against Communist China, although it could strengthen resistance to insurgency and political pressure'. ${ }^{351}$

For the JIC, the British withdrawal would cause serious tensions between Malaysia and Singapore. 'They will be left face to face with each other and with Indonesia. They will need to readjust themselves, in their external and internal policies, to their new situation'. ${ }^{352}$ The British withdrawal was already causing a re-examination of Singapore and Malaysia's relations with one another and them and the wider region. ${ }^{353}$ Meanwhile, Indonesia would continue to focus on internal security and economic development. Suharto was thought likely to stay in power over the next five years. Suharto was still concerned about China and unwilling to endanger his Western support, but it was felt his government would eventually come into conflict with Indonesia's neighbours as the number of areas of potential conflict was too great. 354

Meanwhile, the JIC believed the Soviet Union had continued to improve its relations with South East Asia. It had promoted commercial, diplomatic, and cultural ties to the region. Its policies were unobtrusive when compared to the 'truculent' attitude of the Chinese. This meant that the Soviet Union had gained influence in the JIC's view and it believed the Soviets would continue to gain influence for the next five years. ${ }^{355}$

Despite the importance of the Vietnam War to the future direction of the region, it was still China that dominated the important final lines of the JIC's report.

While prediction beyond 1973 is uncertain, the main features of the current situation will continue: Chinese Communist ambitions; instability in South-east Asia; United States policy of containment of Communist China; and only limited threats in the South Pacific. ${ }^{356}$

351 'Strategic Assessment 1968-1973 and Beyond', JIC(NZ)(68)3, March 1968, MoD 1/1/2 Vol 3, Review of Defence Policy

352 'Strategic Assessment 1968-1973 and Beyond', JIC(NZ)(68)3, March 1968, MoD 1/1/2 Vol 3, Review of Defence Policy

353 'Strategic Assessment 1968-1973 and Beyond', JIC(NZ)(68)3, March 1968, MoD 1/1/2 Vol 3, Review of Defence Policy

354 'Strategic Assessment 1968-1973 and Beyond', JIC(NZ)(68)3, March 1968, MoD 1/1/2 Vol 3, Review of Defence Policy

355 'Strategic Assessment 1968-1973 and Beyond', JIC(NZ)(68)3, March 1968, MoD 1/1/2 Vol 3, Review of Defence Policy

356 'Strategic Assessment 1968-1973 and Beyond', JIC(NZ)(68)3, March 1968, MoD 1/1/2 Vol 3, Review of Defence Policy 


\subsubsection{Debate in the Defence Council}

The JIC's assessments did not meet a favourable response when the report was distributed to the Defence Council. The council was not prepared for the JIC's shift in the way conflict was categorised or for the committee's views on the level of threat. The council still saw China as posing a significant threat of limited war. The Chief of Air Staff Cameron Turner noted the lack of references to limited war and a lack of detail on China's nuclear programme. He thought the tone of the JIC report suggested that the situation was improving when he believed that it was much less favourable than the JIC's assessment. This triggered a discussion in the council on the definition of limited war. The Chief of Defence Staff, Leonard Thornton, defined limited war 'as excluding the use of nuclear weapons and participation by the Soviet Union'. ${ }^{357}$ The Council believed that:

A statement of the likelihood (during the next five years) of limited war in South East Asia with Communist China was needed in the paper to enable Council to assess whether Government should be advised that this was a contingency against which New Zealand should prepare. ${ }^{358}$

The Secretary of External Affairs, George Laking, ${ }^{359}$ was also concerned that the JIC had not detailed the risk of Chinese intervention. Laking felt the Vietnam War continued to provide a chance of limited war with China. He thought 'there was a day-to-day possibility of Chinese intervention [in South East Asia]'. 360

RM Mullins, the JIC Chairman, responded to the comments by the chiefs saying that the committee had tried to avoid using the term limited war and added that the committee 'had been tasked with considering "likely situations". 361

'If a specific assessment of the possibility of conventional warfare involving Communist China was required [,] it could be provided [,] but was unlikely to go beyond the comments contained in the previous strategic assessment (JIC(NZ)(67)1)'. ${ }^{362}$

Mullins said he did not believe that the possibility of renewed confrontation with Indonesia needed further investigation. He also stated that he did not see an early settlement of the Vietnam conflict.

\footnotetext{
357 Defence Council Minutes, DC/M/(68)9, 12 March 1968, MoD 1/1/2 Vol 3, Review of Defence Policy 358 Defence Council Minutes, DC/M/(68)9, 12 March 1968, MoD 1/1/2 Vol 3, Review of Defence Policy

${ }^{359}$ Laking took over from McIntosh as Secretary of External Affairs in 1967.

${ }^{360}$ Defence Council Minutes, DC/M/(68)9, 12 March 1968, MoD 1/1/2 Vol 3, Review of Defence Policy

361 Defence Council Minutes, DC/M/(68)9, 12 March 1968, MoD 1/1/2 Vol 3, Review of Defence Policy

362 Defence Council Minutes, DC/M/(68)9, 12 March 1968, MoD 1/1/2 Vol 3, Review of Defence Policy
} 
Thornton said that the Defence Council should avoid influencing the JIC but could still ask specific questions of the committee. He noted it was the task of the JIC to outline the probabilities and the job of the Council to advise the government on how to prepare for those eventualities. The Council asked the JIC to revise and expand the assessment for 1968-73 to take into account the discussion. ${ }^{363}$ The subsequent revision provided more detail on the likelihood of limited war with China.

While not seeking to initiate limited war, [China] will underwrite [its] objectives by the possession of a limited nuclear deterrent and an improved conventional capability. It is possible, though unlikely, that Communist China might become involved in major hostilities with the United States and its allies in which it deploys substantial forces into South-east Asia, as a result of the escalation of the situation in Vietnam and, less likely, Laos. In the unlikely event of [a] United States invasion of North Vietnam, Communist China would substantially increase its direct involvement in the Vietnam conflict and, in the event of operations in the Red River Delta, would intervene in strength. We believe, however, that Communist China will continue to be cautious about a clash with the United States and seek to promote its objectives by support for indigenous communist and antiwestern forces. ${ }^{364}$

The members of the Defence Council were still not completely happy with the new revision. Mullins explained that the JIC wanted to avoid the term 'limited war' as it could be interpreted a number of ways. He agreed with the council that 'major hostilities' could be replaced with the words 'overt and direct military engagement'. ${ }^{365}$ Thornton was also critical of the assessment's view on how long it could be until Confrontation could reoccur. Mullins agreed that it was possible beyond 1973.

\subsubsection{External Affairs and Foreign Policy Goals}

The next step would be for the council to have the Secretary of External Affairs outline the priorities for New Zealand's defence objectives in terms of New Zealand's foreign policy. Thornton believed the Strategic Outlook Paper established the need for the following military activities:
A) Continuing military assistance to Vietnam
B) Continuing military presence in Malaysia and Singapore

\footnotetext{
363 Defence Council Minutes, DC/M/(68)9, 12 March 1968, MoD 1/1/2 Vol 3, Review of Defence Policy

364 'Strategic Assessment 1968-1973 and Beyond', JIC(NZ)(68)3(Revise), 15 March 1968, MoD 1/1/2 Vol 3 , Review of Defence Policy

365 Defence Council Minutes, DC/M/(68)17, 19 March 1968, MoD 1/1/2 Vol 3, Review of Defence Policy
} 
C) The provision of 'on call' forces to meet SEATO commitments to the level of counter-insurgency - This would mean being able to provide assistance to Thailand if requested.

D) Depending on findings of the Strategic Outlook Paper: the need to contribute forces in the event of limited war.

E) Small scale military aid to the Pacific. ${ }^{366}$

The paper developed by External Affairs for the Defence Council outlined New Zealand's national defence objectives and the current strategic requirements. The national defence objectives had not changed from previous statements and still included vague objectives such as 'the preservation of security and national interests'; the maintenance of security and stability of allies; material backing for collective defence; willingness to make efforts to support the national interests of allies (and thus make a claim for a voice in important decisions); and to maintain the commitment of the US and - to the extent possible - the UK to the security of areas of 'primary strategic concern to New Zealand'. ${ }^{367}$ External Affairs expressed the view that the size and nature of New Zealand forces should be related to the missions of: maintaining the ability to deploy into the Pacific in situations that relate to New Zealand's national interest primarily; contributing to vital air and sea communications; contributing to the security of friendly countries in the areas of primary strategic importance to New Zealand; maintaining standby forces to assist the UN or NZ defence partners; and contributing to the general deterrent effect of Western forces. ${ }^{368}$ With the possible exception of Western deterrence, these goals are largely consistent with New Zealand's defence objectives today. ${ }^{369}$

While these objectives had remained fairly consistent, External Affairs acknowledged that the external environment had changed over the previous three years and so too had the effect that change would have on New Zealand's defence requirements. The department's opinion neatly summed up the relationship between the Vietnam War and the larger objective of Chinese containment.

\footnotetext{
366 Defence Council Minutes, DC/M/(68)9, 12 March 1968, MoD 1/1/2 Vol 3, Review of Defence Policy

367 'Defence Objectives and Strategic Requirements', Annex A to DO(68)23, 18 March 1968, MoD 1/1/2 Vol 3, Review of Defence Policy

368 'Defence Objectives and Strategic Requirements', Annex A to DO(68)23, 18 March 1968, MoD 1/1/2 Vol 3, Review of Defence Policy

369 The New Zealand Defence White Paper 2010 lists armed forces as having a role in a safe and secure New Zealand, including its border and approaches; a rules-based international order which respects national sovereignty; a network of strong international linkages; and a sound global economy underpinned by open trade routes. Defence White Paper 2010, New Zealand Ministry of Defence, November 2010, p. 15, http://www.nzdf.mil.nz/downloads/pdf/public-docs/2010/defence_white_paper_2010.pdf
} 
Since the Defence Council report 1/65, the United States and its allies have introduced substantial combat forces into Vietnam and the war has taken on a new dimension. The JIC report notes, and this Department agrees, that in several respects the Vietnam war is of critical importance to the future: it will have a significant effect on the development of Chinese communist policy generally, in the area; it will almost certainly determine the course of developments in Cambodia and Laos; it will profoundly affect the situation in other South East Asian countries; it will affect the policy of major powers outside South East Asia, both friendly and unfriendly; and its outcome will profoundly influence the United States policy (whether, for instance, the United States maintains forces in mainland South East Asia). ${ }^{370}$

External Affairs also noted the effect of British withdrawal on logistics, the 'radical' changes in Indonesia, setbacks in UN peacekeeping, and the diminished importance of SEATO due to independent American actions, and the decline in British, French, and Pakistani participation. $^{371}$

The conclusions reached by External Affairs had implications for Vietnam, Chinese containment, Malaysia/Singapore, the Pacific, and peacekeeping. The need to provide combat forces for operations in Vietnam or a similar emergency had become of greater importance over the previous three years. A capability for a larger contribution to a 'greater emergency' involving a Chinese attack on South East Asia - specifically SEATO Plan 4 was desirable but it was of lesser priority to Vietnam type activities. ${ }^{372}$ The department was much less convinced of the need for a continued New Zealand presence in Malaysia and Singapore than the Ministry of Defence and the chiefs. External Affairs thought such a presence should only be considered in conjunction with Australia and with the cooperation of Malaysia/Singapore. It would also need the understanding, if not the underwriting, of the US. The department warned of costs in 'men, money and political and military risk' that needed to be balanced against the value of any contribution to South East Asian security, ${ }^{373}$ the benefits of which would depend on the terms of any agreement which replaced the

\footnotetext{
370 'Defence Objectives and Strategic Requirements', Annex A to DO(68)23, 18 March 1968, MoD 1/1/2 Vol 3, Review of Defence Policy

371 'Defence Objectives and Strategic Requirements', Annex A to DO(68)23, 18 March 1968, MoD 1/1/2 Vol 3, Review of Defence Policy

372 'Defence Objectives and Strategic Requirements', Annex A to DO(68)23, 18 March 1968, MoD 1/1/2 Vol 3, Review of Defence Policy. Minor edits later by the Defence Council on 19 March 1968

373 'Defence Objectives and Strategic Requirements', Annex A to DO(68)23, 18 March 1968, MoD 1/1/2 Vol 3, Review of Defence Policy
} 
AMDA and the level of freedom New Zealand forces would have to operate in the wider region. ${ }^{374}$

Thornton questioned the relative importance of the goals outlined in the External Affairs paper. He wondered whether a Plan 4 scenario was really of lesser importance than the Vietnam commitment. The Chief of Defence Staff put it that greater resources would be required for Plan 4 operations over the longer term.

In this respect it could be accepted that New Zealand, in common with its major allies, would not wish to "place everything in the shop window". She should have the capacity to make an effective contribution to the greatest threat envisaged i.e. the possibility of involvement in an overt and direct engagement between the forces of Communist China on the one hand and the USA on the other. ${ }^{375}$

\subsubsection{Missions of Forces}

The most important document produced during the 1968 review process was the 'Missions of Forces' report. This outlined the objectives of New Zealand defence policy. It brought together the JIC's analysis of the threats, the policy goals identified by External Affairs, and created a set of mission statements for the armed forces. In one sense it formed the complete strategic outline, as it showed how military means would be brought to achieve political ends. As a consequence, this document neatly expressed New Zealand's strategic challenges. One example is the tension between the traditional desire for collective security and the realities of Cold War security.

As a small power with world wide interests, New Zealand continues to reject "neutralism" or "isolationism" as a practicable basis of national policy and has long recognised that its security and protection of national interests abroad must be found through collective security arrangements. Short of a world wide system for effective peace-keeping, New Zealand can serve its own national policies and interests best by active participation in regional collective defence arrangements in the areas of primary strategic concern[:] South East Asia and South Pacific. At the same time New Zealand should continue to support the principles of collective action, as lain down in the United Nations Charter, and work to make the world organisation a more effective body in the peace-keeping field. ${ }^{376}$

\footnotetext{
${ }^{374}$ In addition to South East Asian commitments, the department also mentioned requirements for small scale military aid to the Pacific and a UN peacekeeping capability: 'Defence Objectives and Strategic Requirements', Annex A to DO(68)23, 18 March 1968, MoD 1/1/2 Vol 3, Review of Defence Policy 375 Defence Council Minutes, DC/M/(68)17, 19 March 1968, MoD 1/1/2 Vol 3, Review of Defence Policy

376 'Defence Review 1968: Missions of Forces', DO(68)25 Second Revise, c. April 1968, MoD 1/1/2 Vol 3, Review of Defence Policy
} 
'Missions of Forces' based its description of the threat to New Zealand interests in South East Asia on the JIC and External Affairs reports, but it still identified China as the most serious threat.

The most serious threat we are likely to face in the foreseeable future is the pursuit by Communist China of an expansionist foreign policy in South East Asia aimed at displacing Western power and influence in the area. The undermining of the states in an area of such importance would pose a direct threat to the security and national interests of New Zealand. ${ }^{377}$

While the JIC may have begun moving away from seeing China as a threat which could bring about a major war, the basic premise of avoiding all threats from China remained in New Zealand's strategic DNA. China was still the most serious threat to New Zealand's interests but the likelihood of war had decreased significantly.

The 'Missions of Forces' report noted that, regardless of the direction of New Zealand's position in South East Asia, New Zealand security would have to be guaranteed by the largest power in the Pacific. The need for protection by the Pacific hegemon had been a fundamental position of New Zealand strategy since the $19^{\text {th }}$ century but was confirmed by the Pacific War.

The ANZUS Treaty continues to be basic to New Zealand defence policy. By remaining linked, like Australia, with the dominant power in the Pacific, we can best protect New Zealand against any repetition of a major threat from a great power in Asia. ${ }^{378}$

In a change from the JIC report, the 'Mission of Forces' report considered it less likely that the US would withdraw from the Asian mainland. However, both reports thought that the US would continue to attempt to contain China to some extent.

The United States policy of containment of Communist China will continue and it is in our interests that there be no weakening of this resolve. Although United States strategy could vary significantly, depending on the outcome in Vietnam, it is unlikely that the United States would contemplate a complete military withdrawal from mainland South East Asia. ${ }^{379}$

\footnotetext{
377 'Defence Review 1968: Missions of Forces', DO(68)25 Second Revise, c. April 1968, MoD 1/1/2 Vol 3, Review of Defence Policy

378 'Defence Review 1968: Missions of Forces', DO(68)25 Second Revise, c. April 1968, MoD 1/1/2 Vol 3 , Review of Defence Policy

379 'Defence Review 1968: Missions of Forces', DO(68)25 Second Revise, c. April 1968, MoD 1/1/2 Vol 3, Review of Defence Policy
} 
The 'Missions of Forces' report was critical of SEATO and expressed a desire for a grouping that was more representative of the countries of the region. Such a grouping was not considered likely and insurgency and instability would continue in the region for some time. This meant New Zealand was best served by continuing its military and economic aid to South East Asia which would be 'vital to the stability of the area whilst the slow process of nation building continues and indigenous defence capabilities develop'. ${ }^{380}$

Instability in South East Asia, carrying a risk of strategic deterioration or of escalation, must be of concern to New Zealand, since the undermining of states in the area by communist movements or the establishment of regimes subservient to a militant Communist China would pose a threat to the security and national interests of New Zealand and, even more directly, to Australia with which our long term security is indissolubly linked. ${ }^{381}$

While the 'Mission of Forces' report may have used the kind of strong language about China that the JIC had avoided using, the link between the Vietnam War and the containment of China was again severed explicitly. The defence review process of 1965 had seen the aggression of North Vietnam and the Vietcong as being linked inextricably with Chinese expansionism. In 1968, the 'Mission of Forces' report denied the certainty of the earlier perspective: 'The extent of North Vietnam's military involvement in the South, and the support of Communist China and the Soviet Union is no longer in doubt'. ${ }^{382}$ What had not changed was the sense that New Zealand's security interests were for the wider region rather than having any direct connection to Vietnam, but nevertheless New Zealand would have to remain committed to that conflict: 'New Zealand's strategic interest in the security of South East Asia and in a United States commitment to regional defence would suggest that the most pressing mission of our armed forces in the next few years will be the provision of combat ready forces in South Vietnam'. ${ }^{383}$

As part of the compromise between the JIC and the Defence Council, the term 'limited war was replaced with 'major hostilities', although the intended meaning appears to be the same. The analysis is also striking for its lack of reference to SEATO:

\footnotetext{
380 'Defence Review 1968: Missions of Forces', DO(68)25 Second Revise, c. April 1968, MoD 1/1/2 Vol 3 , Review of Defence Policy

381 'Defence Review 1968: Missions of Forces', DO(68)25 Second Revise, c. April 1968, MoD 1/1/2 Vol 3 , Review of Defence Policy

382 'Defence Review 1968: Missions of Forces', DO(68)25 Second Revise, c. April 1968, MoD 1/1/2 Vol 3 , Review of Defence Policy

383 'Defence Review 1968: Missions of Forces', DO(68)25 Second Revise, c. April 1968, MoD 1/1/2 Vol 3 , Review of Defence Policy
} 
Though unlikely, we have to take account of the risk that Communist China may engage in major hostilities with the United States and its allies in South East Asia. Our principal allies plan against such an eventuality and will expect New Zealand to be able to contribute to the defence of South East Asia and its sea and air approaches. New Zealand will therefore have a continuing interest in maintaining a capability to meet an emergency of this kind. This will require suitable follow-on forces to supplement forces which may be held forward. Since their deployment is relatively unlikely, they will, however, have lesser priority than the provision of ready forces for Vietnam and similar emergencies. ${ }^{384}$

This represents a major weakening of the language when compared to the 1965 review and even the documents of 1968 that feed into this report. There is no longer an assumption that New Zealand's part in SEATO planning would provide a guideline for New Zealand's force structure. China was still a threat but it had been side-lined almost to the level of the threat of global war, which had been all but ignored since the Cuban Missile Crisis. New Zealand would still have to prepare for 'major hostilities' but Vietnam and similar emergencies were the greater priority.

Concern over the British withdrawal continued. While the 'Missions of Forces' report still expressed confidence in the US remaining tied to the region through Vietnam, the British withdrawal was still seen as having the potential to kill the Forward Defence strategy. With no decision yet made on the future of New Zealand's place in Malaysia/Singapore, the 'Missions of Force' statement is unsurprisingly pessimistic. The lack of certainty put the authors in the position of having to describe a strategic vision when one of the linchpins of the existing structure was under threat.

The British withdrawal will in particular cut direct across the arrangements on which New Zealand, and, in a less dependent sense, Australia, have maintained forces forward - acclimatised, equipped and trained to respond to emergencies ranging from the initial response to the requirements of SEATO plans, up to and including major hostilities involving Communist China. By dramatically reducing the logistic support available to us, British withdrawal will seriously affect, if not eventually call into question, our forward defence strategy. ${ }^{385}$

The problem of the difficult balancing of Malaysia/Singapore and Vietnam was a continuing headache for planners. The Vietnam War was more important for New Zealand's long-term interests in maintaining a friendly great power in the region and containing China. However,

\footnotetext{
384 'Defence Review 1968: Missions of Forces', DO(68)25 Second Revise, c. April 1968, MoD 1/1/2 Vol 3, Review of Defence Policy

385 'Defence Review 1968: Missions of Forces', DO(68)25 Second Revise, c. April 1968, MoD 1/1/2 Vol 3, Review of Defence Policy
} 
Malaysia and Singapore were looking to New Zealand and Australia to fill the void left by British withdrawal. Staying in Malaysia/Singapore without British support added to the risk that New Zealand could be drawn into a local conflict between the two countries or between either Malaysia or Singapore and Indonesia. Yet at the same time New Zealand and Australia would be unable to provide a force capable of providing military guarantees, especially without the US or UK 'underwriting' the project.

Despite these problems there were advantages in retaining a permanent presence in Malaysia/Singapore. A presence would assist in local stability while still allowing the freedom to employ forces to other parts of the region. Indonesia was willing to accept New Zealand and Australian forces at the, then, current levels and the presence helped maintain good relations with Malaysia and Singapore. ${ }^{386}$ These arguments seem quite removed from the earlier arguments that pointed to the potential for communist insurgency. The role of China in New Zealand's deployment to Malaysia/Singapore was slipping away. Nevertheless, while the continued presence in Malaysia/Singapore was yet to be proved politically or economically sustainable, it remained New Zealand's second priority after Vietnam, with a force able to contribute to 'major hostilities' being the third priority. ${ }^{387}$

During 1968 the individual services would develop their own plans based on the 'Mission of Forces' and their own needs. This would largely amount to a set of shopping lists that set out the upgrade needs for each service. The effect of the statement of mission would have differing consequences for the three services. For instance, the RNZAF largely had to continue its programme of upgrades that had been in development for some time. The programme included the purchase of the Skyhawks and C-130s that had already been planned. The purchases would necessitate the increase of the manpower ceiling from 5,025 to 5,300 through to the early $1970 \mathrm{~s} .{ }^{388}$ The need for detailed spending plans meant progress was slow. It would be October 1968 by the time the debate over financing the new review would occur.

\footnotetext{
386 'Defence Review 1968: Missions of Forces', DO(68)25 Second Revise, c. April 1968, MoD 1/1/2 Vol 3, Review of Defence Policy

387 'Defence Review 1968: Missions of Forces', DO(68)25 Second Revise, c. April 1968, MoD 1/1/2 Vol 3 , Review of Defence Policy

388 'Size and Shape of the RNZAF', 17 April 1968, MoD 1/1/2 Vol 3, Review of Defence Policy
} 


\subsubsection{Finding the Money}

By October the new defence review was in a state to be examined by Cabinet and Treasury. Given that the review had been prompted by the reluctance of Cabinet to fully fund the previous review, it is unsurprising that Treasury was critical of the proposed spending and manpower increases. Getting the review funded was a serious battle for Thomson and the military. The conflict would improve Treasury's understanding of defence planning but the much desired defence upgrades would struggle to get past an increasingly sceptical Cabinet and growing public opposition to the Vietnam War. The language used by the military establishment to describe the military situation in South East Asia would not change but the response of Treasury and Cabinet would become even more hostile to the ambitions of the military.

Uncertainty still hampered decisions on funding. Australia's post-withdrawal plans were still unclear and the manpower implications of the review were yet to be finalised. Given these uncertainties, the quantum of the defence budget over the next five years was still yet to be determined. Abandoning the bases in Malaysia/Singapore would not mean a saving in manpower. In a Cabinet Defence Committee meeting, Thomson stated that if maintaining the Forward Defence bases in South East Asia was not approved then the alternative would be cooperating with Australia in a continental defence strategy and this would involve greater commitments for New Zealand. ${ }^{389}$

At the same the military chiefs were becoming more and more downbeat about and hostile to the financial constraints placed on them. Thornton told the Cabinet Defence Committee that the strategic situation was 'getting worse with no prospect of improvement'. ${ }^{390}$ Increases in defence funding were necessary in order to maintain New Zealand's capabilities. He told the Cabinet committee that they had a choice between accepting an inadequate level of national security and increasing defence expenditure. He outlined the various effects of the three levels of expenditure provided by Treasury would have on defence capabilities. If the figure of $\$ 460$ million for five years was adopted, then there would have to be substantial cuts in equipment on order. The medium figure of $\$ 500$ million would mean no further orders and the top figure of $\$ 540$ million would mean no further growth in capabilities.

\footnotetext{
389 Minutes of Cabinet Defence Committee, D (68) M 6 Part 1, 4 October 1968, MoD 1/1/2 Vol 5, Review of Defence Policy

390 As referenced in: Minutes of Defence Committee, COS/M(68)27, 3 October 1968, MoD 1/1/2 Vol 5, Review of Defence Policy
} 
Even with the largest option the services would need to cancel increases in manpower and equipment upgrades. However, Treasury official, R.J. Leathwick, doubted New Zealand could afford defence to take up as much of GNP as even the smallest figure represented. He recommended that Cabinet defer any decision until the costs of restructuring in other parts of the economy had been established. ${ }^{391}$ The Defence Council was forced to outline in some detail the effects of each option ${ }^{392}$ and build closer links with Treasury in order to overcome their scepticism. ${ }^{393}$

\subsubsection{Losing Strategic Perspectives}

The conflicts over financing and the uncertainty of the direction of allies led External Affairs and Treasury to oppose the Government making any new statements on defence policy. External Affairs felt that there were a number of 'inhibiting factors' that should prevent the Defence Council from presenting a view to government for consideration before May 1969. ${ }^{394}$ However it was the financial challenges that were causing concern for military leaders. There were always significant lead times for new equipment before it became operationally effective. Any long gap in purchasing would not be able to be caught up even if the military need became pressing, which the chiefs (with their pessimistic attitude toward China and Asia) considered to be possible. The defence establishment needed interim decisions to be made even if the new defence review was not to be released for some time. It was the opinion of the Ministry of Defence that the Defence Council needed to quickly resolve any disputes between the various departments so that they could provide clear advice to the Government at least on administration and planning and thus work towards longer term policy. ${ }^{395}$

These immediate needs were pressuring the Ministry of Defence to put the cart before the horse. As the Ministry could not get a firm direction or budget numbers from the Government, the Ministry looked to obtain confirmation for what it saw as its immediate needs rather than a programme built on a government-approved strategic policy. This problem was at the heart of the objections by External Affairs. The department saw the

\footnotetext{
391 Minutes of Defence Committee, D (68) M 6 Part 1, 4 October 1968, MoD 1/1/2 Vol 5, Review of Defence Policy

392 Draft 'Equipment Purchases', MoD 1/1/2 Vol. 5, Review of Defence Policy

393 By March 1969 Treasury was working with Defence to improve government-wide financial decision making: Sec Treasury to SecDef, 20 March 1969, MoD 1/1/2 Vol 5, Review of Defence Policy

394 Memo for Defence Council, DO(68)81, 11 November 1968, MoD 1/1/2 Vol 5, Review of Defence Policy

395 Memo for Defence Council, DO(68)81, 11 November 1968, MoD 1/1/2 Vol 5, Review of Defence Policy
} 
Forward Defence concept as being in fundamental danger in the post-Vietnam War environment due to Australian indecision and 'the absence of positive indications of future United States policy in South East Asia'. ${ }^{396}$ These factors were fundamental to the concept of Forward Defence as it was stated in the draft 1968 review. If Forward Defence could not be maintained, then the review process would have to begin again and new statements of defence objectives and policy would have to be developed.

The Ministry of Defence was critical of External Affairs' perspective as it believed that even if major changes in New Zealand's strategy had to occur, its interests in the region would not. New Zealand would still want to contribute to collective defence in South East Asia even if forces could no longer be forward deployed. Even if New Zealand had to withdraw its forces from South East Asia within five years, the necessary force structure would remain largely unchanged as forces would still need the ability to deploy rapidly to South East Asia in a crisis. The developments in capability that defence had hoped for were not dependent on whether New Zealand forces remained stationed on the Asian mainland. ${ }^{397}$ These differing positions reflected the interests of their respective institutions. External Affairs was focused on maintaining the relationships with the allies, whereas Defence was concerned with sustaining their capabilities in a time of financial restraint.

By the end of November officials finally had some level of certainty as to the foreign bases but still not for the budget. Australian Prime Minister John Gorton announced publicly that Australian forces would remain in Malaysia/Singapore until 1971. This allowed Holyoake to announce that New Zealand forces would remain in Malaysia and Singapore at 'about the [then] present level until the end of 1971'. ${ }^{398}$ Thomson used this as an argument for the need to avoid a reduction in New Zealand's capabilities and fully fund the defence programme. ${ }^{399}$ Thomson wrote to Robert Muldoon (now the Minister of Finance) outlining the need to keep defence budgeting at the figure of $\$ 650$ million for the next five years. Thomson criticised Cabinet's procrastination with defence spending noting the number of broken defence programmes which led to uncoordinated procurement, deferred combat readiness, and retention of obsolete equipment. For this the Minister of Defence blamed a 'discrepancy between Vote provisions and the readiness of Government to give actual approvals for

\footnotetext{
396 Memo for Defence Council, DO(68)81, 11 November 1968, MoD 1/1/2 Vol 5, Review of Defence Policy

397 Memo for Defence Council, DO(68)81, 11 November 1968, MoD 1/1/2 Vol 5, Review of Defence Policy

398 Press statement by Keith Holyoake, 20 November 1968, MoD 1/1/2 Vol 5, Review of Defence Policy

399 Thomson to Muldoon, c. early 1969, MoD 1/1/2 Vol 5, Review of Defence Policy
} 
expenditure'. 400 While Thomson thought that New Zealand's armed forces had met the tests of the 1950s and 1960s, he noted that the future was not likely to be easier. ${ }^{401}$

In March 1969 the leader of the opposition, Norman Kirk, acknowledged that 'fundamental changes' were about to take place in Asia and argued that the Government's defence policy did not take these into account. However, Kirk still approved of the decision for New Zealand forces to remain in Malaysia and Singapore. Forward Defence, in Kirk's view, was primarily to keep Britain and the US interested in defending the region. He noted that SEATO was weak and ineffective and that New Zealand was doing nothing to shore up the alliance. He pointed to Indonesia and Japan with which New Zealand needed closer relations but were outside of SEATO. Kirk argued for a greater emphasis on economic aid to South East Asia rather than defence assistance. These points were made without reference to Vietnam and only a passing reference to China. He noted that the Government had changed its views on China and had started to favour recognition of Beijing. ${ }^{402}$

\subsection{CONCLUSION: DISAPPEARING CHINA}

The financial debate would continue well into 1969 with Cabinet continuing to defer making a concrete decision on the five-year programme. Instead Cabinet again balked at the cost. The review process continued at a crawl and would not be completed until 1972. In the meantime, Cabinet only funded major purchases that it was already contractually obliged to make, such as the Skyhawks and the fourth frigate. ${ }^{403}$ Through 1969 the financial debate would become all-encompassing as the strategic questions in relation to China had largely been answered in 1968. China's role as the top level threat was over and so were the alliance structures and commitments that held China's containment together. New Zealand's involvement in Vietnam was initially in pursuit of containing China, but by 1968 no one was making that argument. The Vietnam conflict was now a serious problem and the defence establishment feared the US would become disinterested in the region once the war was over. The 1968 review would ultimately fail to materialise into a public document because the strategic picture continued to evolve faster than the ability of the Government and bureaucracy to plan for the future.

\footnotetext{
400 Thomson to Muldoon, c. early 1969, MoD 1/1/2 Vol 5, Review of Defence Policy

401 Thomson to Muldoon, c. early 1969, MoD 1/1/2 Vol 5, Review of Defence Policy

402 Press statement by the Leader of the Opposition, 10 March 1969, MoD 1/1/2 Vol 5, Review of Defence Policy

${ }^{403}$ Minutes of the Cabinet Defence Committee, D(69)M1, 29 April 1969, MoD 1/1/2 Vol 6, Review of Defence Policy
} 
The decline of SEATO's relevance meant it was less clear what capabilities New Zealand should provide for South East Asian security. SEATO's significance to New Zealand seemed to shrink over the course of 1968 with later documents making fewer references to it. SEATO's marginalisation brought institutional rivalries to the fore as the shape and extent of a post-Vietnam and post-containment defence policy was fought out between External Affairs, Defence, and Treasury. Once it became clear that it was possible to keep bases in Malaysia/Singapore and once greater involvement in Vietnam became even less desirable, then those debates became more about financing rather than strategic direction. Yet, the rationale of these decisions was not fully appreciated at the time. A continued presence in Malaysia/Singapore was only credible if the primary purpose of those bases changed from containing China to responding to smaller emergencies around the immediate region.

\subsubsection{The Disappearance of China}

Attitudes to China and the details of New Zealand strategy changed over the course of 1968 . How and when views changed in different parts of the defence policy making apparatus is clouded by the fact different parts were writing at different times. By focusing on the next five years and intelligence (rather than policy), Mullins and the JIC provided the least selfinterested assessment. While the overall level of instability in the region had not fallen, the likelihood that China would involve itself in a major conflict in the region had reduced. The JIC initially completely eliminated any prediction of limited war with China and only made mention of it at the insistence of the incredulous Defence Council. Yet it appears that the

Defence Council came to accept the lower risk of Chinese intervention by placing it as the third most important defence priority.

Not only was the perceived threat of China dissipating, the structures for containment were also being lost. The UK was going and US commitment to the region was sapping as the Vietnam conflict dragged on. In early 1968 it was feared New Zealand could not maintain a military place in Asia without the UK but as the year went on it became easier to remain. The support of Malaysia, Singapore, and Australia was crucial to remaining in Malaysia/Singapore but, as the previous review suggested, a presence in Asia would have been pointless if it was not at least underwritten by a major power. With the decline in Chinese threat, the arguments in favour of retaining forces in Malaysia/Singapore became more compelling, especially when contrasted against greater involvement in Vietnam. 


\subsubsection{Institutional Rivalries}

Undertaking a new review of defence policy would always be difficult, perhaps even unwise, when there was so much uncertainty as to the direction New Zealand defence could be taken. As a small player in the network of Western powers, New Zealand was limited by the options of its partners. This was managed much more easily when the containment of China was the paramount concern and SEATO provided the framework for containment in South East Asia. By 1968 containment was being swamped by Vietnam and the weariness of Britain and the United States to South East Asian entanglements. Without the convenient structures that containment had brought New Zealand, planners had to find their own way to a much greater extent than they had in the past. This problem intensified institutional rivalries as External Affairs, Defence, and Treasury all pushed a strategic direction based on their own interests rather than fulfilling their place in a fairly well established framework. The points of difference came not only from the level of financial need but also the direction of military effort.

The priority of the Ministry of Defence and the chiefs was to maintain their operational capability. British withdrawal was a major challenge, but so was a lack of investment in new equipment. The upgrades prepared for during the course of the 1960s were at risk and most of these would simply keep the armed forces at a similar level of capability. On top of this, new logistic support and administration would have to be developed in order to cope with the British withdrawal. The chiefs were acutely aware of how long it took to plan for, obtain, and deploy new major purchases. A quickly changing political or strategic environment might cause the loss of defence funding which could have disastrous consequences if the climate changed suddenly for the worse. Yet, at the same time, it was much harder to make a case for new capability development when the threat of a major conflict was decreasing. The bases at Singapore and Malaysia were an asset that, if lost, would be impossible to replace. A switch to greater involvement in Vietnam was looking increasingly like an unsustainable proposition. Given the threats to their funding and foreign bases, the chiefs were not inclined to see the strategic situations as improving even if the JIC told them the threat of a high intensity conflict with China was decreasing.

For External Affairs the priority was maintaining the alliance system that had been carefully managed since the formation of ANZUS and ANZAM. Relations between Malaysia and Singapore had been difficult and continuing New Zealand's military presence could place it 
in a difficult position if those relations became even more fraught. A greater investment in Vietnam could shore up American commitment to the region after the conflict ended. While External Affairs seem to have given up trying to convince the US to keep bases on the South East Asian mainland it still wanted to maintain the protection from a distance that had been seen previously as inadequate. However, as the review progressed through the turbulent year of 1968, it would be hard to imagine that External Affairs' argument for greater involvement in Vietnam gained any popularity amongst Cabinet or the other parts of the civil service.

Treasury was deeply concerned with containing the costs of defence as a portion of government expenditure and GNP. What is notably different from the experience of the 1966 review is the attempt of Treasury and Defence to work together to build a better understanding in Treasury of defence needs. While Treasury's reluctance to allow the expansion of defence spending tells us little of the exchequer's views on strategy, it does show the Treasury's inflexible views on the importance of defence relative to other functions of government.

\subsubsection{Finding Our Own Way}

The year 1968 would not only be transformative in terms of creating a defence policy that was not dominated by the containment of China but also transformative in terms of the rationale for the Forward Defence strategy. The loss of great power support and the diminished need for containment (at least in the way that New Zealand had promoted it) meant that Forward Defence required a new raison d'être. Instability in South East Asia was now seen as a regional problem primarily rather than one directed from Beijing. In that context New Zealand and Australia could make a useful contribution without the direction or immediate support of a major power. However, this does not mean that New Zealand no longer saw China as hostile; it simply thought a limited war with China was no longer a significant possibility and that the Western political will to contain it in South East Asia had gone. A new more diplomatic path would be needed to avoid the spread of Chinese influence in South East Asia. This diplomatic effort would be more flexible and able to adjust once China came out of the excesses of the Cultural Revolution and looked to engage with the West. 


\section{External AfFairs and the CULtURAL ReVolution}

\subsection{INTRODUCTION}

New Zealand's view of China would undergo a major change with the upheaval caused by the Great Proletariat Cultural Revolution. ${ }^{404}$ The revolution would help break down the idea that China was a credible military threat to South East Asia and put in motion a shift towards the view that diplomatic engagement was not only possible, but the best way of securing New Zealand's interests in Asia. The nature and objectives of Mao's last revolution were debated by Western and Soviet-bloc sinologists as both camps struggled to explain the explosion of radical political activity and disorder in the PRC during the decade-long conflict. The Western observers followed by New Zealand officials were split between those that saw the revolution as a purge of those opposing Mao's vision of perpetual revolution and those who saw it as a struggle for power between those who might succeed Mao after his death. Mao's aims were generally thought to be the revitalisation of the Chinese communist revolution and to avoid China becoming a bureaucratised police state like the Soviet Union. As Richard H. Donald of the US State Department wrote in a paper which he shared with the New Zealand Embassy in mid-1967:

[A] clearer picture... has emerged of the ultimate objectives in Mao's mind when he instituted the Cultural Revolution - the establishment of an Utopian [sic] communism based on the broadest democracy held together more by the commonly shared and implicitly accepted code of ideology and ethics known as Maoism than by rigid control and organisational forms. ${ }^{405}$

While the revolution would last a decade, its most radical period would be in the first two years, 1966 to 1968, when Mao utilised China's youth to form the 'Red Guards'. These were groups of young political activists driven by ideological fervour and their glorification of Mao. They denounced traditional sources of authority, attacked China's cultural heritage, and rooted out bourgeois elements, 'capitalist roaders', and Soviet 'revisionists'. Slogans such as 'bombard the headquarters' and to 'rebel is justified' were used to encourage a radical

404 NZHC Ottawa to SecEx, 4 January 1968, NYP 3/16/1 Vol. 6, Political Affairs - China - General, 1967 68, ABHS W4628 6958 Box 46, ANZ: Fraser also wrote a brief history of the Cultural Revolution up to the end of 1968 and this was shared with New Zealand officials in Ottawa who considered it useful.

405 Richard H. Donald, 'The Course of the Cultural Revolution', US State Department internal paper, c. June 1967, NYP 3/16/1 Vol. 6, Political Affairs - China - General, 1967-68, ABHS W4628 6958 Box 46, ANZ 
breakdown of communist and traditional social structures and sources of power. ${ }^{406}$ 'The masses', encouraged by Mao and his closest supporters, clashed violently with local governments which were dissolved across the country in favour of 'revolutionary committees'. Leaders of the Party and PLA alike were removed from their positions and subjected to public denouncements. Foreign diplomats, including those from Britain and the Soviet Union were attacked, and relations with almost all of China's neighbours became tense. In June 1967 Red Guards broke into the British Embassy and assaulted three British officials. ${ }^{407}$ In 1968 the Cultural Revolution moved out of its most turbulent phase with Mao reining in the Red Guards. The PLA began taking a stronger role in political life and maintenance of order which was largely achieved by the start of 1969 .

The nature of these events in China were extremely unclear. New Zealand's own sources of information were limited but External Affairs had good access to the outside observers of larger powers. The New Zealand Commission in Hong Kong was a major conduit and analyser of such information. Wellington's officials around the world needed to pick apart the occasionally conflicting opinions of its diplomatic and intelligence partners. The discussions between New Zealand officials and their counterparts in friendly nations provided the basis of New Zealand's information stream on events in China. Those incoming assessments of events in China would often be in conflict with one another. However, it is the reports by New Zealand officials of their discussions with friendly nations which provide a specifically New Zealand perspective on events in China. The media was also a major source of information. This was not restricted to Western media as Japanese and, to a lesser extent, Soviet-bloc reports were also considered useful.

This chapter utilises the reports made by New Zealand diplomatic missions on their discussions on the Cultural Revolution with officials from their host countries. These reports include foreign assessments and relevant press clippings. They were shared with Wellington and distributed to New Zealand's other missions around the world. While it is not clear the extent to which External Affairs shared these reports directly with the defence chiefs, their strong links through the Defence Council and the JIC meant it is unlikely that the chiefs were unaware of the information on China flowing from the diplomatic service.

\footnotetext{
406 Roderick MacFarquhar, Mao's Last Revolution, Kindle Edition, Belknap Press, March 15, 2008, Location 1313 of 9789

407 Melvin Gurtov, 'The Foreign Ministry and Foreign Affairs during the Cultural Revolution', The China Quarterly, No. 40, Oct. - Dec. 1969, pp. 65-102
} 
In the first year of the revolution the reports collected by External Affairs expressed a strong feeling that chaos and irrationally had overcome China and analysts initially struggled to make sense of the revolution. Two main schools of thought emerged, one seeing it as a purge of Mao's enemies, the other focused on the struggle to succeed him. New Zealand's diplomatic circles avoided falling too heavily into either camp, but regardless of the approach taken it was necessary to try and understand what factions existed in the Chinese government and which ones were in control. Broadly, the battle was viewed by New Zealand officials as being between those committed to Mao's vision of perpetual revolution and those keen on political stabilisation and economic reforms. However, the huge number of Chinese officials at all levels who were being denounced, dismissed, or rehabilitated at any one time made it exceptionally difficult to understand where power lay at any given moment. The place of Premier Zhou Enlai was considered to be hugely important to New Zealand observers as his competence and practicality were admired by many around the world. The role of the PLA was also of keen interest as it was the military that was correctly assumed by New Zealand officials as the source of order when Red Guard violence got out of hand. The Chinese military would also come to have a significant role in the creation of revolutionary committees which would displace the CCP-based organisation of local government across China.

The ability and desire of the Chinese leadership to control or place limits on the disorder would have huge implications for China's foreign policy. It would affect the likelihood of an intervention in Vietnam or some other foreign adventure like an attack on Hong Kong. If the Chinese leadership was unwilling or unable to control the revolution, then a serious miscalculation was much more likely. If the revolutionaries were being kept from threatening China's external security, then it was much more likely that China would stay inward looking and not threaten its neighbours. New Zealand's diplomats and their counterparts overseas were split on this question. The Americans changed their opinion regularly and Frank Corner appears to have considered the situation in China (at least at one point) to be uncontrolled chaos. ${ }^{408}$ However, the New Zealand Commission in Hong Kong argued strongly that the Chinese leadership could, would, and were keeping the revolution under its control and would avoid taking the People's Republic into a dangerous clash with its neighbours.

\footnotetext{
408 NZ Ambassador US, Frank Corner, to SecEx, 8 September 1967, ABHS W5579 6958 Box 121, NYP 3/16/3 2, Political Affairs - China - Hong Kong 1967-1997
} 
The end of 1968 would see the completion of the transfer of power in China to a triplealliance of the party, the military, and revolutionary groups, even if in reality much of the power was in the hands of the PLA and what remained of the party apparatus. ${ }^{409}$ This would dampen much of the disorder even if it did not improve China's foreign relations. Skirmishes along the Soviet border occurred over much of 1969, highlighting the risk posed by the USSR and refocusing the need for change in foreign policy amongst China's leaders. These changes would allow for better relations with the West, even if Chinese ambitions remained largely unchanged.

\subsection{External Affairs' SOURCES FOR EVEnTS In ChinA}

A major source of information for New Zealand diplomats on events in China were their discussions with their British, American, Canadian, Indian, French, and Australian colleagues. These discussions make up the best available evidence of New Zealand's assessments on China during the late 1960s and early 1970s. Open source and secret intelligence reports - especially those of the Joint Intelligence Committees of the UK, Australia and Canada - were provided to Wellington, but (as with the New Zealand JIC reports) only a few are currently available publicly. The minutes and most reports of the New Zealand Joint Intelligence Committee for this period (other than those referred to in other chapters) remain classified or have been lost. ${ }^{410}$ The files of the New Zealand Mission to the United Nations provide the most complete record of these discussions, supplemented by the reports of the New Zealand Commission in Hong Kong which provide the clearest New Zealand official perspective on events in the People's Republic.

Information from larger friends and allies was not taken uncritically. Reports by New Zealand's foreign missions often interwove their own views with those of their foreign counterparts, fudging the distinction when they agreed with their host's analysis and only making direct comments when they disagreed explicitly with what they were being told. ${ }^{411}$ External Affairs made some effort to establish the biases and blind spots of their friends. The Cultural Revolution did not affect External Affairs' preferences for information sources on

${ }^{409}$ Roderick MacFarquhar, Mao's Last Revolution, Kindle Edition, Belknap Press, March 15, 2008, Chapters $14-15$

${ }^{410}$ Requests at MFAT managed to uncover a small number of JIC reports outside those contained in other files examined for this research. These additional reports made little reference to China.

${ }^{411}$ For instance, the NZHC in Ottawa was of the view that Canadian analysis could be clouded by the Canadian debate over recognition of the PRC. NZHC Ottawa to SecEx, 24 January 1967, NYP 3/16/1 Vol 5, Political Affairs - China - General, ABHS W4628 6958 Box 46, ANZ 
China. Prior to the Cultural Revolution, American views on China had generally received less criticism from New Zealand officials than other sources. The British had been viewed by Wellington as underestimating the threat from Beijing and overestimating its ability to be accommodated. The Canadians and the Australians were also, like New Zealand, more cautious although lacking the occasionally fanatical anti-communism that could come out of Washington and that had marked analysis of the early Cold War.

There is no indication from the files available that External Affairs was utilising information from New Zealand communists visiting China let alone sharing that information with their foreign colleagues.

\subsubsection{Hong Kong Commission}

The New Zealand Commission in Hong Kong (referred to hereafter as 'the commission') stands out as the most independent New Zealand source and analyser of information on China during the late 1960s. With no official New Zealand representation in either Beijing or Taipei, the Hong Kong commission was the only New Zealand diplomatic post in wider China. It utilised wide contacts and sources in the colonial administration, Chinese language media inside and outside the PRC, business people trading in the PRC, and most importantly the British Embassy in Beijing. The commission's direct link to the British Embassy gave it a link to events in Beijing that were unmatched by other New Zealand posts, despite the hardships placed on British diplomats during the Cultural Revolution.

The commission produced the largest volume of reports on China during the late 1960s of any New Zealand overseas post. The commission was especially active during the Hong Kong riots of 1967 and the violence in Guangdong the following year. Over the course of 1967 and 1968 it built a view that highlighted the limits placed on the revolution by the central leadership. The commission's view looked past the chaos of the revolution and saw the rational forces at play and the desire on the part of Zhou Enlai and even the hard line Maoists to ensure that the revolution did not endanger China's foreign interests and external security, especially in Hong Kong.

While Hong Kong provided a crucial source of information on China for New Zealand policy makers, the colony's security was not in the forefront of the minds of New Zealand's defence planners. It did not receive any significant attention during the 1966 or the (unfinished) 1968 defence reviews, nor was there any obvious expectation that New Zealand would be involved in any immediate defence of the colony in a crisis. Wellington had made 
some preparations for the defence of Hong Kong in the period immediately before the creation of the PRC. In August 1949 New Zealand agreed to provide Dakota cargo planes to assist in Hong Kong's defence. ${ }^{412}$ By November that year that situation had calmed. New Zealand's chiefs were sent British intelligence reports which were confident that China's new communist leaders had no plans to take the colony by force. In the late 1960s it seems that New Zealand had left the defence of Hong Kong up to the British. This is possibly because the territory would have been very difficult to defend. In 1956 the British JIC (Far East) recommended using nuclear weapons immediately after a hypothetical Chinese invasion began. ${ }^{413}$ As with its view prior to the Second World War, New Zealand's focus was on South East Asia with Singapore providing the linchpin of the British defence of New Zealand interests rather than Hong Kong, but Hong Kong was a major post for trade with mainland China and thus the important point of contact for information about the mainland.

\subsubsection{The Media and Big Character Posters}

The international media was an important source for New Zealand officials. The official Chinese press was collected and analysed by the commission in Hong Kong. Other New Zealand missions collected their host country's reporting from China and distributed them to other New Zealand posts around the world. In the first year of the revolution New Zealand officials took advantage of Japanese press reports as these provided 'the bulk of the reports' on events in Beijing. ${ }^{414}$ Japanese reporters could blend in more successfully and usually had better Chinese written language skills than their Western counterparts. Their ability to read dàzibào (big-character posters) was especially useful. Reports from Soviet-bloc journalists were also utilised but were often treated as fanciful by the commission. ${ }^{415}$ Yugoslav reporting was treated more seriously. ${ }^{416}$ The Far Eastern Economic Review and The Economist were regular sources of reporting and the work of Roderick MacFarquhar was particularly popular at the New Zealand Commission in Hong Kong.

\footnotetext{
412 MinExternal to NZ High Commissioner Canberra, 17 August 1949, JSO 32/16/2, 165/2/1 1, ABFK W5767 19754 Box 125, Hong Kong - Defence, 1948-56

413 'Military Threat to Hong Kong up to 1960', 3 August 1956, Annex to JIC(FE)(56)50 Final, 165/2/1 1, ABFK W5767 19754 Box 125, Hong Kong - Defence, 1948-56

${ }^{414}$ NZ Commissioner in Hong Kong to SecEx, 12 January 1967, NYP 3/16/1 Vol 5, Political Affairs - China - General, ABHS W4628 6958 Box 46, ANZ

415 NZ Commissioner in Hong Kong to SecEx, 12 January 1967, NYP 3/16/1 Vol 5, Political Affairs - China - General, ABHS W4628 6958 Box 46, ANZ

416 B. Bogunovic, 'The Storm in July', Politika, c. late 1966; NZ Commissioner in Hong Kong to SecEx, 12 January 1967, NYP 3/16/1 Vol 5, Political Affairs - China - General, ABHS W4628 6958 Box 46, ANZ
} 
During the revolution big-character posters and billboards became a major system of communication between numerous revolutionary groups. Dàzibào were a major source of information on who was currently facing criticism and which groups were in control of an area at a given time. The commission saw big-character posters as a form of 'free press' where the Red Guards could make statements and attack enemies. ${ }^{417}$ Dàzibào in Beijing were treated by the commissioner as being reasonably authoritative on events in the capital, but less so if the posters depicted events in the provinces. For example, dàzibào reports of 40 dead and 500 injured in violence in Nanjing were thought to be exaggerations by observers in Hong Kong. However, stories of violence in Shanghai were regarded in Hong Kong as accurate. ${ }^{418}$ Meanwhile, the New Zealand High Commission in Ottawa did not put much faith in the posters, but accepted they were the best source of information at times. ${ }^{419}$

During the course of the first two years of the revolution it became increasingly difficult for foreign journalists to operate in China. Increasing restrictions were placed on foreign journalists and they were eventually barred from reporting on the posters or on anything not covered in the official Chinese media. The Cultural Revolution sparked, in the words of the commission, a 'spy mania' which saw the detainment of several Western individuals, both communists and journalists alike. New Zealand officials were aware of the British Reuters correspondent Anthony Grey's detention in July $1967 .{ }^{420}$ Grey was released in October 1969. ${ }^{421}$ Another British journalist, Norman Barrymaine, was detained for over 18 months ${ }^{422}$ but a month into his confinement New Zealand officials knew only that he had disappeared. ${ }^{423}$ The commission's concern had been sparked by press reports in New Zealand that even Rewi Alley was under suspicion. ${ }^{424}$ Only cursory attention seemed to have been paid to private New Zealand citizens in China, but the New Zealand Commission in Hong Kong was active in checking with the British if any New Zealanders had been

\footnotetext{
417 NZ Commissioner in Hong Kong to SecEx, 12 January 1967, NYP 3/16/1 Vol 5, Political Affairs - China - General, ABHS W4628 6958 Box 46, ANZ

418 NZ Commissioner in Hong Kong to SecEx, 12 January 1967, NYP 3/16/1 Vol 5, Political Affairs - China - General, ABHS W4628 6958 Box 46, ANZ

419 High Commissioner Ottawa to Acting SecEx, 18 January 1967, NYP 3/16/1 Vol 5, Political Affairs China - General, ABHS W4628 6958 Box 46, ANZ

${ }^{420}$ NZ Acting Commissioner Hong Kong to SecEx, 30 April 1968, ABHS W5579 6958 Box 121, NYP 3/16/3 2, Political Affairs - China - Hong Kong 1967-1997

421 'Foreign Correspondents: The Tiny World of Anthony Grey', TIME Magazine, 20 December 1968, http://content.time.com/time/magazine/article/0,9171,844706,00.html

422 Norman Barrymaine, The Time Bomb: Today's China from the inside, Taplinger, 1975

${ }^{423}$ NZ Acting Commissioner Hong Kong to SecEx, 30 April 1968, ABHS W5579 6958 Box 121, NYP 3/16/3 2, Political Affairs - China - Hong Kong 1967-1997

${ }^{424}$ NZ Acting Commissioner Hong Kong to SecEx, 30 April 1968, ABHS W5579 6958 Box 121, NYP 3/16/3 2, Political Affairs - China - Hong Kong 1967-1997
} 
detained in the PRC. ${ }^{425}$ In February 1968, L.W. Tattersfield, a New Zealand businessman trading with China, told the commission that as he left the country customs officials had cut out images of posters from photographs he had taken. ${ }^{426}$ By April that year the commission understood Mongolian diplomats were the only foreigners able to read the posters with any immunity. ${ }^{427}$

\subsubsection{New Zealanders in China}

There is no evidence that New Zealand diplomats utilised the PRC's New Zealand supporters in their discussions of the Cultural Revolution and Chinese policy. In fact, the contempt of the commission for New Zealand communists is evident when it described the visit of the General-Secretary of the Communist Party of New Zealand, V.G. Wilcox. ${ }^{428}$ Wilcox had already been to China several times and in March 1967 he received another warm welcome by the Chinese leadership. Zhou and Kang Shen greeted him at the airport where several hundred listened to Wilcox speak. Later Wilcox met with Mao, Zhou, and Kang. The commission noted the lavish treatment of Wilcox and took it as a sign of China's increasing international isolation and the lack of foreign supporters of real influence.

The CPNZ and its leaders have in recent years been accorded special treatment by Peking. When Wilcox last visited China (in March 1966) he was met at Peking Airport by Secretary-General [Deng Xiaoping], and was given a banquet by Chairman [Liu Shaoqi] ... Comrade Wilcox probably could not have foreseen that these faces would be missing in March 1967, or that this time he would be met on arrival by no-one less than [Zhou Enlai] and awarded the supreme accolade of a meeting with Chairman Mao. Peking surely is scraping the bottom of the barrel. ${ }^{429}$

\subsection{PuRge AND StRUgGLE}

External Affairs' understanding of the Cultural Revolution focused initially on establishing the facts on the ground followed by attempts at making sense of the political reasoning for the revolution and the future direction of Chinese policy. Mao's desire to uproot the political

${ }^{425}$ NZ Acting Commissioner Hong Kong to SecEx, 30 April 1968, ABHS W5579 6958 Box 121, NYP 3/16/3 2, Political Affairs - China - Hong Kong 1967-1997

${ }^{426}$ NZ Commission in Hong Kong to SecEx, 6 February 1968, ABHS W4628 6958 Box 46, NYP 3/16/1 Vol. 6, Political Affairs - China - General, 1967-68

${ }^{427}$ NZ Commission in Hong Kong to SecEx, 30 April 1968, ABHS W4628 6958 Box 46, NYP 3/16/1 Vol. 6, Political Affairs - China - General, 1967-68

${ }^{428}$ Commissioner 15 March 1967, NYP 3/16/1 Vol 5, Political Affairs - China - General, ABHS W4628 6958 Box 46, ANZ

${ }^{429}$ NZ Commission Hong Kong to SecEx, 15 March 1967, NYP 3/16/1 Vol 5, Political Affairs - China General, ABHS W4628 6958 Box 46, ANZ 
system he had created and sow mass discontent made little sense to Western observers who saw it as irrational and having a detrimental effect on the economy. Outside observers, even those in the diplomatic community, had little information on which to base their assessments. External Affairs' confidence in understanding events in China was low despite the cooperation of their American and Commonwealth counterparts who were also struggling to understand the situation. The New Zealand High Commission in Ottawa (quoting from a confidential Canadian report) recognised that little could be established firmly:

This interpretation is clearly speculative, as must be any attempt to impose a pattern on domestic events in China, especially since early 1966. The bald fact is that to a great extent we do not know what has happened in China and that where we are able to clearly identify events, we must fall back on speculation, sometimes very tenuous, in placing interpretations on them. ${ }^{430}$

By early 1967 two schools of thought emerged in the academic and journalistic communities that External Affairs followed. One group was known as the 'purge' school. This school favoured the notion that Mao was attempting to remove those who did not follow his vision of perpetual revolution and distaste for 'Soviet revisionism'. This school placed Mao at the centre of events and saw him as supremely powerful. Mao was using new political organisations - such as the Red Guards - to criticise and humiliate those that favoured reforms. Yet the ability of other perspectives to survive the political and physical attacks shows that some form of dissent was still possible, albeit from a weak position due to Mao's cult of personality.

The competing perspective was the 'struggle for power'. That school saw the revolution as being a competition between the Chinese leadership to succeed Mao. This school saw Mao as a weaker figure: a man in failing health overrun by the conflicts around him. The political factions that emerged during the revolution were of interest to both camps. The competing factions were central to the 'struggle' school but those who saw a 'purge' also noted the importance of factions in the leadership as they tried to measure the amount of opposition to Mao. Members of the diplomatic community (which New Zealand officials were part of) tried to avoid aligning themselves with either camp, yet these competing views often framed discussions on China.

430 NZHC Ottawa to Acting SecEx, 18 January 1967, NYP 3/16/1 Vol 5, Political Affairs - China - General, ABHS W4628 6958 Box 46, ANZ 
The NZHC in London considered the division between the purge and struggle schools to be largely an American debate. ${ }^{431}$ British experts and Foreign Office officials were thought more to focus on policy over personality factors. The high commission noted the opinions of a number of British commentators. The Economist, The Times, and Roderick MacFarquhar writing in The New Statesman and the Sunday Telegraph all referred to Mao's desire for continual revolution and abhorrence of Soviet revisionism. ${ }^{432}$ The NZHC in London shared an article by Richard Harris in The Times which dismissed the struggle for power argument. Harris noted that Mao's opponents were not solely concerned with supplanting him as most had been committed to Mao for decades. Harris considered any struggle for power to be a secondary concern. Contrasting those views, the NZHC London noted that, in The Guardian, Victor Zorza supported the 'struggle' perspective arguing that there was a struggle between the Left and Right factions, with Lin Biao trying to destroy the Right faction in the party to ensure his place in the succession. However, it was the views of MacFarquhar and Harris that the NZHC London considered to reflect the general opinion of British experts and 'to a large extent' the UK Foreign Office. ${ }^{433}$

At the turn of 1967 the US State Department was very concerned about the situation in China and described the picture to the New Zealand officials as 'one of a breakdown of authority and near anarchy'. ${ }^{434}$ The main contact for China policy in the US State Department for New Zealand's Washington Embassy staff was the Deputy Director of the Office of Asian Communist Affairs, Richard H. Donald. Donald did not subscribe fully to either the struggle or the purge camp, ${ }^{435}$ and tended to focus more on the chaotic nature of the revolution. Donald and his colleagues could not understand why Mao and Lin Biao were willing to harm their personal prestige when the revolution was potentially so damaging to the economy and Chinese state. The Americans told the New Zealanders that the revolution's political attacks were aimed at undercutting the power of the CCP apparatus, but the Americans thought attacks on the political structures that underpinned industry and

\footnotetext{
${ }^{431}$ NZHC London to SecEx, 19 January 1967, NYP 3/16/1 Vol 5, Political Affairs - China - General, ABHS W4628 6958 Box 46, ANZ

432 The Economist, 14 January 1967; The Times, 7 January 1967; The Sunday Telegraph, 1 January 1967. All of these are referenced in NZHC London to SecEx, 19 January 1967, NYP 3/16/1 Vol 5, Political Affairs China - General, ABHS W4628 6958 Box 46, ANZ

${ }^{433}$ NZHC London to SecEx, 19 January 1967, NYP 3/16/1 Vol 5, Political Affairs - China - General, ABHS W4628 6958 Box 46, ANZ

${ }^{434}$ NZ Embassy Washington to SecExternal, 10 January 1967, NYP 3/16/1 Vol 5, Political Affairs - China General, ABHS W4628 6958 Box 46, ANZ

${ }^{435}$ NZ Embassy Washington to SecEx, 6 March 1968, NYP 3/16/1 Vol 6, Political Affairs - China - General, 1967-68, ABHS W4628 6958 Box 46, ANZ
} 
agriculture were designed to hit Mao's opponents in the regions rather than a deliberate attempt to spread the revolution to those sectors of the economy.

The Cultural Revolution decision [sic] to extend these [revolutionary] activities to industry and the countryside is a measure of desperation undertaken in order to undercut areas of organisational strength controlled by the party apparatus. The guidelines to industry and agriculture are a call for anarchy and are totally irresponsible... The consequences of extending the cultural revolution to the countryside may be critical. ${ }^{436}$

Canadian assessments obtained by New Zealand were closer to American opinions than British ones. The Canadian perspective was based on the assumption that the Mao-Lin faction was in control of the Government and that the PLA had a considerable amount of loyalty to them. In the view of the NZHC Ottawa the Canadian perspective was somewhat clouded by the internal debate going on in Canada over the question of official recognition, whereas the Americans believed that Mao had not yet been able to enforce his will on the CCP and his control of the country had diminished. ${ }^{437}$

While the possibility was discussed, the breakdown of order caused by the revolution was never seriously thought likely to descend into civil war by New Zealand officials or their friends overseas. The Americans were the most concerned about further disorder, whereas the French Foreign Ministry was the least convinced by the idea of a civil war. In February 1967 the French were already telling the New Zealand Embassy in Paris that it looked to them as though order was being restored in China. ${ }^{438}$ The French Foreign Ministry believed that Mao's enemies had been defeated and that the Government was looking to normalise the situation in China. The disorder in Inner Mongolia and Tibet were considered special cases by the French due to the ethnic differences of those provinces. Indian officials were similarly relaxed about the Cultural Revolution in their discussions with the New Zealand High Commission in Delhi. The Indians thought that the disorder was not having a massive effect on China. ${ }^{439}$ They thought the damage to the economy was limited, there had not been any widespread fighting and there was not any major discontent in the army. Civil war or the collapse of the state was unlikely in the Indian view.

\footnotetext{
436 NZ Embassy Washington to SecEx, 10 January 1967, NYP 3/16/1 Vol 5, Political Affairs - China General, ABHS W4628 6958 Box 46, ANZ

437 NZHC Ottawa to SecEx, 24 January 1967, NYP 3/16/1 Vol 5, Political Affairs - China - General, ABHS W4628 6958 Box 46, ANZ

438 NZ Embassy Paris to SecEx, 17 February 1967, NYP 3/16/1 Vol 5, Political Affairs - China - General, ABHS W4628 6958 Box 46, ANZ

439 NZHC Delhi to SecEx, 19 January 1967, NYP 3/16/1 Vol 5, Political Affairs - China - General, ABHS W4628 6958 Box 46, ANZ
} 
The New Zealand Commission in Hong Kong also questioned whether China was in a state of civil war and whether the breakdown of central authority was being surrendered to the provinces. While not answering these questions directly, it did see the situation as extremely complex with multiple groups in violent conflict with one another.

\begin{abstract}
We have commented previously that, despite Lin [Biao]'s recent description of the current situation in China as a "civil war without guns", what seems to be happening is not civil war but violent clashes, not between two clearly defined sides, but among two, three or even more groups - contending factions all claiming to be Mao supporters, supporters of party cadres endeavouring to preserve the status quo, peasants and workers taking up arms to protect themselves from Red Guard disruption, and the PLA itself split. ${ }^{40}$
\end{abstract}

Even if outright civil war wasn't thought likely by New Zealand's diplomatic circles, it was still not clear the extent to which the chaos was being controlled - rather than simply initiated and incited - by Mao and his supporters. Disorder was generally seen as being in Mao's interest (especially by the purge school) but it was also destabilising to the economy and China's foreign interests. Mao was perceived broadly as favouring revolutionary furore as an end in-and-of itself as well as seeing it as a method of removing enemies. Yet at the same time analysts in New Zealand and abroad wondered at what point and in what places Mao would try to limit the disorder. One official report in External Affairs' files described the Maoist leadership as being unwilling rather than unable to limit the disorder except for brief periods for economic necessity, but also using such periods as a method of control:

The next such period may be the hiatus called for by the autumn harvest and grain collection. The next such pause over the last two years, however, has been only an introduction to a renewed swing to the "left" and toward new disorders immediately thereafter during which eager or enthusiastic welcomers of the "pause" period have been swept away by the flood of Jacobin enthusiasm. ${ }^{441}$

On 5 April 1967 a number of Commonwealth diplomats (including those from the New Zealand High Commission), representatives of the Foreign Office, and the Commonwealth Secretariat met at Marlborough House to discuss the developments in China that year. ${ }^{442}$

\footnotetext{
${ }^{440}$ NZ Commission in Hong Kong to SecEx, 25 August 1967, NYP 3/16/1 Vol 6, Political Affairs - China General, ABHS W4628 6958 Box 46, ANZ

441 'The Cultural Revolution in Communist China: Summer 1967', official report with no stated author and unclear origin, ABHS W5579 6958 Box 121, NYP 3/16/3, Vol 2, Political Affairs - China - Hong Kong 1967-1997

442 NZHC London to SecEx, 17 April 1967, NYP 3/16/1 Vol 5, Political Affairs - China - General, ABHS W4628 6958 Box 46, ANZ
} 
The summary of the discussion detailed criticism of the idea that the revolution was a struggle for power and the attendees generally considered it to be more about the future ideological direction of the People's Republic.

There does not appear to have been a struggle for power in the sense of attempts being made to overthrow Mao or predetermine the line of succession. Rather it has been Mao seeking to determine the ideology that will survive after him and to remove those who might undermine it. This action has no doubt produced a reaction, especially since all must be assuming that Mao is unlikely to last much longer and will therefore be concerned to get themselves well positioned for the new era after Mao... But the struggle at present would nonetheless be better characterised as a struggle of ideologies - a clash between Mao's "revolution" and Liu ShaoChi's "revisionism" ... [Mao's] endeavours have now become more strongly and urgently manifest because of his worry that Soviet type Communism was taking root in China and also that the bureaucracy of the Party was becoming divorced from the mass. It could indeed be argued that he is currently trying not to purify the Party but to get round the back of it. ${ }^{443}$

The revolution was also accompanied by a rapid escalation in Mao's cult of personality. This did not escape the attention of the Americans. They saw Mao as being recognised as a 'prophet' of Marxism on the same level as Lenin and Marx himself, rather than Mao simply being seen as an interpreter of Marxist-Leninist thought. ${ }^{444}$ The New Zealand Commission in Hong Kong also noted Mao's personality cult but were still puzzled by the complete lack of public attacks on Mao when so many other powerful Chinese leaders were being condemned. The commission noted that the personality cult was being utilised to attack Mao's enemies and the splintering revolutionary organisations judged each other on their adherence to Maoist dogma: 'The immense prestige and charisma of the Chairman remains one of his greatest weapons'. ${ }^{445}$

In June, Donald wrote a paper which was shared with New Zealand officials. In it he outlined Mao's goals for the Cultural Revolution which he saw as a state of perpetual revolution and a society held together by ideology rather than bureaucratic authoritarianism. ${ }^{446}$ While Donald had concerns about the security of Hong Kong, he was

443 NZHC London to SecEx, 17 April 1967, NYP 3/16/1 Vol 5, Political Affairs - China - General, ABHS W4628 6958 Box 46, ANZ

444 NZ Embassy Washington to SecEx, 12 April 1967, NYP 3/16/1 Vol. 5, Political Affairs - China - General, ABHS W4628 6958 Box 46, ANZ

445 NZ Commission in Hong Kong to SecEx, 25 August 1967, NYP 3/16/1 Vol. 6, Political Affairs - China General, ABHS W4628 6958 Box 46, ANZ

446 Richard H. Donald, 'The Course of the Cultural Revolution', US State Department internal paper, c. June 1967, NYP 3/16/1 Vol 6, Political Affairs - China - General, 1967-68, ABHS W4628 6958 Box 46, ANZ 
relatively sanguine on the overall direction of the Cultural Revolution. It was becoming the view of American officials that the revolution was to some extent under the control of the Chinese leadership.

...the PLA remains a coherent force, responsive to Peking's orders. Although it has not in fact restored order, except in isolated cases such as that of Wuhan, it probably still has the ability to do so, if and when the leadership can make up its mind to issue unequivocal instructions. It can hardly be said therefore that the situation is completely out of control. In this respect, Donald said, the pendulum of opinion [in Washington] has lately been swinging back, and more emphasis is now being placed on the fact the Chinese leadership itself is responsible for the present state of affairs. Whether it is that Mao cannot make up his mind, or that there is a tug-of-war between two or more groups below him, the fact is that the regime does not seem capable of deciding on a course of action and sticking to it. If it could, and did, the PLA could probably ensure that its wishes were carried out; but in fact the Army seems not to know what is required of it and for this reason its efforts are largely ineffectual. ${ }^{447}$

New Zealand ambassador to the US Frank Corner was somewhat amused by Donald's assessment as Corner believed little had changed in China over the previous few months of 1967, while the attitudes of Western countries had shifted. To Corner the US assessment of a totally or somewhat controlled revolution was moving against the tide of opinion. Corner's tone suggests that he did not agree with the American view of controlled 'chaos' but does not state it explicitly. As he saw it 'others' were coming to:

recognize that China is in chaos, and even... contemplate the possibility of [it] breaking up [whereas] the Americans are off on another tack, stressing the possibility of the situation being brought under control, if and when the leadership can pull itself together. ${ }^{448}$

By 1968 confidence grew among New Zealand's diplomatic circle as to the nature of the revolution but this does not mean there was any greater consensus. The commission was increasingly of the view that the Chinese Government was still a coherent entity and that it could place limits on the revolution when it wanted or needed to do so. In its view the revolution did not mean China would act without any predictability or rationality. Donald did not agree with the commission's view that the leaders of the Cultural Revolution could be separated from the Chinese government. Donald saw the two as interwoven and neither as acting with any consistency. In Donald's view, the sources and motivations of power in

\footnotetext{
447 NZ Ambassador US, Frank Corner, to SecEx, 8 September 1967, ABHS W5579 6958 Box 121, NYP 3/16/3 2, Political Affairs - China - Hong Kong 1967-1997

448 NZ Ambassador US, Frank Corner, to SecEx, 8 September 1967, ABHS W5579 6958 Box 121, NYP 3/16/3 2, Political Affairs - China - Hong Kong 1967-1997
} 
Beijing were unknowable and unpredictable. He noted the August 1967 attack on police in London by Chinese diplomats. Donald saw this as a staged event under orders but could not say by whom. ${ }^{449}$

\subsubsection{Finding the Factions}

While the nature of the revolution was an overarching concern for New Zealand diplomats and their Western counterparts, the day-to-day focus of officials was establishing which political grouping was in control at any one time and what the implications would be for policy, especially foreign policy. Initially the two groups of importance were Mao's faction headed by the Chairman himself and Lin Biao, and reformers headed by Liu Shaoqi and Deng Xiaoping. Deng and Liu were the recipients of the heaviest criticism during the revolution with Mao and Lin singling them out as 'revisionists'. As the revolution continued, with Deng and Liu being marginalised (the latter being secretly imprisoned), assessing which factions were leading the Government became more difficult. A third group, led by Zhou, appeared to emerge. This group was thought by New Zealand officials to be a voice of moderation.

To complicate matters, positions in the PRC government or in the CCP did not necessarily reflect the level of influence a person held. The term Paramount Leader would later emerge in the Deng Xiaopeng era to cope with the fact Deng (and Mao before him) had not held many of the major government offices, but during the Cultural Revolution the distribution of power was very murky. During the revolution it was not clear who was in control of the various organs of state and how well those institutions could function. Top members of the Government and the party were frequently attacked in posters, in the press, or during mass demonstrations; only Mao was above criticism. The fall of an office holder did not necessarily mean a significant change in leadership or policy, but continuity was also a weak indicator of stability. This was not fully understood early in the revolution but became apparent to New Zealand officials as the revolution went on. Officials were also trying to understand the relationship between individuals in the government leadership and a multitude of regional power brokers, the ever splintering revolutionary organisations, and weakened party apparatus. This was a considerable challenge given scarcity of information. Determinations on major shifts were often made on the scantiest evidence.

449 NZ Ambassador US, Frank Corner, to SecEx, 8 September 1967, ABHS W5579 6958 Box 121, NYP 3/16/3 2, Political Affairs - China - Hong Kong 1967-1997 
In the view emanating from the High Commission in Ottawa, as the revolution got going resistance coalesced around Liu Shaoqui and Deng Xiaoping. The fact they remained in their posts as of January 1967, despite the criticism they received, suggested to the NZHC Ottawa that there was serious resistance to Mao and Lin's efforts. The New Zealanders in Ottawa were beginning to see a 'palace guard' forming around Mao headed by Chen Boda and Jiang Qing. These two, combined with Lin Biao and the PLA formed the basis of Mao's power and isolation from the party which they were attacking. ${ }^{450}$

The New Zealand Commission in Hong Kong closely followed the attacks on Liu Shaoqi and his wife Wang Guangmei. For example, in January 1967 the commission reported on Red Guard posters in Beijing showing Liu and Wang on an official trip to Indonesia in 1963. Wang was shown lighting a cigarette for Sukarano and Liu dancing with an Indonesian girl. The caption described Wang as 'intolerable' and Liu as 'crazed with wine and women' and 'an ugly fellow of Khrushchev type'. ${ }^{451}$ The commission noted that rallies followed, with the Red Guards claiming that more than 100,000 people attended in Beijing on 8 January where Liu and Deng Xiaoping were denounced. The following day a Red Guard newspaper quoted Zhou saying that the criticisms were warranted but Mao did not want young revolutionaries to go to excess. ${ }^{452}$ Zhou also told Red Guards that criticisms of others including foreign minister Chen Yi and former vice-premier Tan Zhenlin should cease as they were undergoing 'self-criticism'. ${ }^{453}$ Despite the denouncements and rallies Beijing was reported by the commissioner as peaceful.

The commission also noted, starting in January 1967, the rise of former actress and Mao's wife Jiang Qing. Jiang would become a major player in the Cultural Revolution and become one of the Gang of Four, whose arrest in 1976 would mark the end of the revolution. The commission's interest in Jiang was sparked by an article in The New Statesman by Roderick MacFarquhar. ${ }^{454}$ The commission supported MacFarquhar's suggestion that Jiang was positioning herself as the unchallenged interpreter of Mao's thoughts in his later life. This was thought to be either by Mao using her as a mouthpiece or her own attempt at power. The

\footnotetext{
450 High Commissioner Ottawa to Acting SecEx, 18 January 1967, NYP 3/16/1 Vol 5, Political Affairs China - General, ABHS W4628 6958 Box 46, ANZ

451 NZ Commissioner in Hong Kong to SecEx, 12 January 1967, NYP 3/16/1 Vol 5, Political Affairs - China - General, ABHS W4628 6958 Box 46, ANZ

452 NZ Commissioner in Hong Kong to SecEx, 12 January 1967, NYP 3/16/1 Vol 5, Political Affairs - China

- General, ABHS W4628 6958 Box 46, ANZ

453 NZ Commissioner in Hong Kong to SecEx, 12 January 1967, NYP 3/16/1 Vol 5, Political Affairs - China - General, ABHS W4628 6958 Box 46, ANZ

${ }^{454}$ Roderick MacFarquhar, 'China: The Balance of Forces', The New Statesman, Vol 73, January 1967. p. 31
} 
commission regarded Jiang as one of the most extreme leaders, but noted that she had lent support to Zhou when he warned revolutionaries against excessive criticism. ${ }^{455}$ Nevertheless there was a reluctance on the part of the commissioner to take Jiang seriously:

As a former actress she may find the Tienanmen [sic] rostrum a more satisfying stage than the Shanghai theatre. The sounder observers, who normally have regard for Macfarquhar's [sic] views, are sceptical of the implication that [Jiang Qing] is seriously in contention as an heir apparent. They are more interested in contemplating the nimble footwork of [Zhou] En-lai. ${ }^{456}$

The Indians were slightly less prejudiced. They noted the growing importance of women in the Cultural Revolution and pointed out Jiang Qing was the most prominent of many female activists and Red Guard members. However, Jiang Qing was also said by the Indians to have a 'personal and rather vindictive vendetta against Mrs Liu'. ${ }^{457}$ Gendered thinking did not stop the Indians from considering Jiang a power broker. They shared the view coming from the Soviets that Kang Sheng was 'an up and coming man' due to his close relationship with Jiang Qing. ${ }^{458}$ The lack of public criticism of Kang suggested to the Russians that he had become allied to Mao and Lin.

Lin Biao was not seen publicly for several months after 26 November 1966 which led some to wonder whether he had suffered a fall from grace. Meanwhile Jiang was seen to rise spectacularly. ${ }^{459}$ In early 1967 the NZHC in Ottawa was unsure of Zhou's position, but it followed the American and Canadian perspective that saw three groupings Mao/Lin/Jiang, Deng/Lui, with Zhou in the middle. Zhou had been a mediator between the two extremes and had occasionally appeared to support either side. At that moment Zhou appeared to be in a position of strength to Canadian watchers. ${ }^{460}$ The commission was initially less convinced of a three way split. It circulated a Yugoslav article ${ }^{461}$ which argued that Deng Xiaoping was not fully aligned with Liu Shaoqi and that it was Deng which represented the third force in

\footnotetext{
455 NZ Commission Hong Kong to SecEx, 19 January 1967, NYP 3/16/1 Vol 5, Political Affairs - China General, ABHS W4628 6958 Box 46, ANZ

456 NZ Commissioner in Hong Kong to SecEx, 12 January 1967, NYP 3/16/1 Vol 5, Political Affairs - China - General, ABHS W4628 6958 Box 46, ANZ

457 NZHC Delhi to SecEx, 19 January 1967, NYP 3/16/1 Vol 5, Political Affairs - China - General, ABHS W4628 6958 Box 46, ANZ

458 NZHC Delhi to SecEx, 19 January 1967, NYP 3/16/1 Vol 5, Political Affairs - China - General, ABHS W4628 6958 Box 46, ANZ

459 NZHC Ottawa to SexEx, 24 January 1967, NYP 3/16/1 Vol 5, Political Affairs - China - General, ABHS W4628 6958 Box 46, ANZ

460 NZHC Ottawa to SexEx, 24 January 1967, NYP 3/16/1 Vol 5, Political Affairs - China - General, ABHS W4628 6958 Box 46, ANZ

461 B. Bogunovic, 'The Storm in July', Politika, no date.
} 
Chinese politics bringing the 'Mao and anti-Mao factions' together in 'order to prevent the destruction of the party apparatus'. ${ }^{462}$ While not in complete agreement with the view from Ottawa, Indian officials told the New Zealand High Commission in Delhi that they saw a strong distinction between the harsh criticism of Liu Shaoqui and the milder treatment of Deng Xiaoping. ${ }^{463}$ The NZHC Delhi also noted that Mao did not have the intention or 'sufficient strength' to eliminate Liu Shaoqui and Deng Xiaoping by Stalinist measures.

The fact Deng and Liu continued to hold positions seemed at first to signify strength on their part, but as time went on New Zealand officials and their China watching contacts, began to wonder if Liu and Deng represented real opposition. There was an acknowledgement that the revolution represented an attempt at a new form of politics. The NZHC Delhi noted that public criticism of government officials was referred to by the Chinese as 'extensive democracy'. A member of the Indian mission in Beijing had been told several times by Chinese friends that they saw the current campaign as a 'pure democracy'. However, the Indian and NZHC Delhi opinion was that Mao was in control of the mass organisations that were denouncing his enemies. ${ }^{464}$ The British felt the real opposition to Mao was not easy to estimate but 'the picture of a nationwide opposition, presided over by Liu and Teng [Deng], is almost certainly a deliberate creation for propaganda purposes'. ${ }^{465}$

In the view of the commission in Hong Kong, power was vested in a small number of people with Mao, Lin, Jiang, Chen Boda, and Kang Shen. Zhou was not seen by the commission as being in the core group but was invaluable in maintaining the economy and limiting excesses. Below them was a large number of changing faces as new people forced themselves to the top only to be found to be lacking revolutionary fervour. The commission said, according to the Soviet Embassy in Beijing, as of February 1967, eighty percent of the Central Committee had been criticised and were now mostly members in name only. ${ }^{466}$

The commission noted that revolutionaries had highlighted and exaggerated 'counter-attacks' from 'bourgeois reactionaries' which were attempting to gain support through offering

\footnotetext{
462 NZ Commissioner in Hong Kong to SecEx, 12 January 1967, NYP 3/16/1 Vol 5, Political Affairs - China - General, ABHS W4628 6958 Box 46, ANZ

463 NZHC Delhi to SecEx, 19 January 1967, NYP 3/16/1 Vol 5, Political Affairs - China - General, ABHS W4628 6958 Box 46, ANZ

${ }^{464}$ NZHC Delhi to SecEx, 19 January 1967, NYP 3/16/1 Vol 5, Political Affairs - China - General, ABHS W4628 6958 Box 46, ANZ

${ }^{465}$ NZHC London to SecEx, 30 January 1967, NYP 3/16/1 Vol 5, Political Affairs - China - General, ABHS W4628 6958 Box 46, ANZ

466 Commissioner to SecEx, 8 February 1967, NYP 3/16/1 Vol 5, Political Affairs - China - General, ABHS W4628 6958 Box 46, ANZ
} 
increased wages and welfare benefits. ${ }^{467}$ Liu and Deng were seen by the commission as being associated with this opposition and having significant support among party officials across the country. However, the commission was uncertain of how coordinated the opposition to Mao's policies were. Unbeknown to the outside world, Liu Shaoqi was placed under house arrest in 1967 and later subjected to torture and severe maltreatment. Despite his incarceration he kept his title as President of the PRC until 31 October 1968. He would die a year later from causes mostly related to his captivity. His arrest was not made public and he continued to be the subject of heavy criticism. ${ }^{468}$

At various points it seemed the revolution was slowing or coming to an end. The northern spring brought the need for the planting of crops which meant a return to the countryside of many who had taken part in revolutionary activity over the winter. Research obtained by the State Department indicated that the only two months when labour was not absolutely required for farm production was from mid-November to mid-January, the months when the revolution seemed to reach a peak. ${ }^{469}$ During the spring planting season of 1967 the British Embassy in Beijing had told the commission that they had detected signs of moderation. Schools begun to resume classes, efforts were made to prevent disruption to spring ploughing, revolutionary exchanges ceased, protests at foreign embassies dwindled, and the army took up responsibility for security in Beijing. The Chinese press was placing a greater emphasis on the role of the PLA in educating the revolutionary masses, ensuring a proper proportion of party officials remained in their posts, and correcting the indiscipline of the revolutionary groups. ${ }^{470}$ To the commission these were signs of consolidation rather than an end to the revolution:

Rather than a complete reversal of Mao's line of unleashing the masses, it is more likely a case of taking one step back in order to take two steps forward. ${ }^{471}$

Signs of a return to normality were short-lived. By April the Americans and the Commission in Hong Kong both noted an increase in denouncements of Deng and Liu. ${ }^{472}$ The New

467 NZ Commission Hong Kong to SecEx, 19 January 1967, NYP 3/16/1 Vol 5, Political Affairs - China General, ABHS W4628 6958 Box 46, ANZ

468 Roderick MacFarquhar, Mao's Last Revolution, Kindle Edition, Belknap Press, March 15, 2008, Location 3991 of 9789

${ }^{469}$ NZ Embassy Washington to SecEx, NYP 3/16/1 Vol 5, Political Affairs - China - General, ABHS W4628 6958 Box 46, ANZ, 12 April 1967

470 Commissioner to SecEx, 22 February 1967, NYP 3/16/1 Vol 5, Political Affairs - China - General, ABHS W4628 6958 Box 46, ANZ

${ }^{471}$ Commissioner to SecEx, 22 February 1967, NYP 3/16/1 Vol 5, Political Affairs - China - General, ABHS W4628 6958 Box 46, ANZ 
Zealand Embassy in Washington noted an article by Stanley Karnow in the Washington Post stating that Mao was rekindling the revolution and that this was damaging the position of Zhou. Donald agreed with the article and said it matched the information the State Department was receiving. Zhou, it seemed to the Americans, was being attacked by the left and the right and 'had blotted his copybook with Mao and that while the old man is prepared to make use of him temporarily he is also looking for an opportunity to get rid of his unsympathetic Premier'. ${ }^{473}$

American experts in the State Department (although not Donald) thought Mao had reluctantly agreed to slacken the pace of the revolution in order to facilitate spring planting, but as of April was willing to relaunch the struggle, but power was increasingly in the hands of the PLA and the civilian bureaucracy. ${ }^{474}$ Meanwhile the British Embassy in Beijing told the Commission that the attacks on Liu were being used as a way of reinvigorating the revolutionary movement and uniting the splintered cadres, while also allowing others to 'purchase forgiveness in return for denouncing Liu'. ${ }^{475}$ The Canadians also saw the up-swing in the revolution as an attempt to shift Zhou, who they considered to then hold the most right wing position in the Chinese leadership. Like the Americans, the Canadians felt the need to ensure food security had ceased to be at crisis levels and so Mao no longer needed Zhou's restraint. ${ }^{476}$ Daniel Molgat at the Canadian Department of External Affairs admitted this view left questions. They could not explain why the attacks on Liu were so intense when Deng was a more obvious scape-goat. Nor could they explain why Liu could not be dismissed from his position as President by a session of the National People's Congress. Yet the Canadians doubted that Mao would be able to revive the revolution as it was bogged down in the provinces. They assumed Zhou was in some way aligned to Liu due to his pragmatic positions, but admitted denouncements of Zhou were still not permissible in April 1967, and thus his position was still solid at that point in time.

\footnotetext{
472 NZ Embassy Washington to SecEx, 12 April 1967, NYP 3/16/1 Vol 5, Political Affairs - China - General, ABHS W4628 6958 Box 46, ANZ

473 NZ Embassy Washington to SecEx, NYP 3/16/1 Vol 5, Political Affairs - China - General, ABHS W4628 6958 Box 46, ANZ, 12 April 1967

474 NZ Embassy Washington to SecEx, NYP 3/16/1 Vol 5, Political Affairs - China - General, ABHS W4628 6958 Box 46, ANZ, 12 April 1967

475 Commissioner to SecEx, 26 April 1967, NYP 3/16/1 Vol 5, Political Affairs - China - General, ABHS W4628 6958 Box 46, ANZ

476 NZHC Ottawa to SecEx, 28 April 1967, NYP 3/16/1 Vol 5, Political Affairs - China - General, ABHS W4628 6958 Box 46, ANZ
} 
Zhou was near universally popular with outside observers. He was seen as competent, reliable, and moderate by the diplomatic circles in which New Zealand discussed China. New Zealand officials had been impressed by Zhou when they saw him up close at the Geneva Conference of $1954^{477}$ and criticism of Zhou is hard to find in any of the discussions New Zealand officials had about China during the Cultural Revolution. Some others, such as the French, expressed open admiration for Zhou. They thought any realistic successor to Mao would require total adherence to Maoist principles, but hoped that Zhou's pragmatism would make him the next supreme leader. ${ }^{478}$ Zhou would continue on as Premier, never seeming to fall out of favour, but never being associated with the revolutionary circle around Mao. Zhou's position would be strengthened after Lin's death in 1971. ${ }^{479}$ Much later, Henry Kissinger noted Zhou's ability to stay both practical and indispensable to Mao almost right up until their deaths in $1976 .{ }^{480}$

The New Zealand commission was always the most confident of Zhou's influence and the ability of the Government to act in moderation when needed or desired. This view stemmed from Beijing's handling of its relations with Hong Kong especially during the communist supported riots that hit the colony in $1967 .{ }^{481}$ The commission noted that foreign trade continued despite the xenophobic rhetoric of the revolution and Beijing's poor relations with the outside world. The attempts at maintaining trade with the USSR was considered by the commission to be strong evidence of the influence of moderate forces in the Chinese leadership or at least the ability of the radicals to act moderately in some areas. ${ }^{482}$ The

477 Daiman Smith, Official Attitudes Toward China Between 1945 and 1957: The Development of the NonRecognition Policy, MA Thesis, Massey University, 1997, p. 74

478 NZ Embassy Paris to SecEx, 17 February 1967, NYP 3/16/1 Vol 5, Political Affairs - China - General, ABHS W4628 6958 Box 46, ANZ

479 The circumstances of Lin's death remain unclear today. New Zealand's diplomats were aware that major events were afoot in September and October of 1971. In the middle of October, the commission noted that a Chinese civilian aeroplane had crashed in Mongolia and that the Chinese government appeared to be actively trying to play down the incident. A week later the commission was speculating that the crash may have been the result of a member of senior Chinese leadership attempting to defect. The British Embassy in Beijing passed on to the commission its view that Lin was dead or dying and that Zhou had ascended to Lin's place, a view supported by the US consulate in Hong Kong. By December the Hong Kong press reported that the CCP was informing its members that Lin had died in the air crash after a failed attempt to assassinate Mao, but the commission warned there was little evidence to confirm these reports. Regardless of the specifics, Lin's death demonstrates how the dampening of the Cultural Revolution did little to improve the opacity of high level Chinese politics to New Zealand observers and their western partners. See: ABHS W4628 6958 Box 46, NYP 3/16/1 Vol. 8, Political Affairs - China - General, 1971

${ }^{480}$ Henry Kissinger, On China, Kindle Edition, Penguin, London, 2011, Chapter 9

481 ABHS W5579 6958 Box 121, NYP 3/16/3 2 Political Affairs - China - Hong Kong 1967-1997

482 New Zealand Commission in Hong Kong to SexEx, 29 August 1967, NYP 3/16/1 Vol 6, Political Affairs China - General, ABHS W4628 6958 Box 46, ANZ 
commission gave Zhou a large amount of credit for keeping the country on track during Mao's revolution.

\begin{abstract}
If anyone deserves the title of China's Man of the Year, it must be Premier [Zhou] who has exerted a decisive influence on the course of events. He early aligned himself with the Maoists and paid appropriate tribute to Mao and Lin [Biao], but he supported prominent party officials under attack until it became impossible not to bend with the wind. Foreign Minister Chen Yi for one probably still holds his position only because of [Zhou's] influence. It is [Zhou] En-lai who has been the supreme negotiator, the chief spokesman of the Party Centre in its endeavours to unite warring Red Guard factions throughout the country. It was he who was primarily responsible for calming the major trouble spots of Wuhan and Canton. While major figures on both right and left have fallen, [Zhou] has remained a dominant figure. ${ }^{483}$
\end{abstract}

Yet the characterisation of Zhou as a moderate was not universally agreed. Alexander, the chairman of the British Joint Intelligence Committee (Far East), told the NZHC Singapore that he did not agree with the characterisation of the competing groups as being moderates and extremists. He saw it more as pragmatists and ideologues. In Alexander's view, the 'moderates' such as Zhou could be very extreme at times, even if he was more pragmatic than the ideologues. ${ }^{484}$

The debates over the direction of the revolution and the makeup and power of the leadership tell us of the difficulty of establishing basic facts of Chinese politics. At the same time, it shows how the New Zealand Commission in Hong Kong and later the rest of the Department of External Affairs became confident of the control Mao had over the revolution. Yet, the commission was still dismissive about the results of the revolution after its first year-and-a-half. The People's Republic had not collapsed or fallen into civil war but neither had China entered into Mao's desired perpetual state of revolution.

Despite the upheaval experienced throughout 1967, China at the beginning of 1968 is still a functioning entity, and the writ of Peking still extends to the country's borders. But Chairman Mao's ideal of a China in a state of perceptual revolution has not been realized. The "little red generals" have been forced to return to the classroom, and rebellion will only be justified if its spearhead is pointed at China's Khrushchev. Those such as the May

\footnotetext{
${ }^{483}$ NZ Commission in Hong Kong, 9 January 1968, NYP 3/16/1 Vol 6, Political Affairs - China - General, ABHS W4628 6958 Box 46, ANZ

${ }^{484}$ NZHC Singapore to SecEx, 5 October 1967, NYP 3/16/1 Vol 6, Political Affairs - China - General, ABHS W4628 6958 Box 46, ANZ
} 
16 Group, who pointed the spearhead in other directions - such as against [Zhou] En-lai - have lost power. ${ }^{485}$

While the extent of the disorder was debated by Western observers, the perceived fluidity of power amongst China's leadership added to the general sense of flux occurring in both China and the wider region. New Zealand officials were generally confident that there were limits being placed on the chaos by Mao, Zhou and others, but the direction of the revolution would depend on how the Chinese military decided to act.

\subsubsection{Role of the PLA}

The role of the PLA was seen by many in New Zealand's diplomatic circles as crucial to China's ability to sustain the revolution without the state collapsing. New Zealand officials kept watch on any signs that the PLA would intervene in the revolution either in support of Mao or against him in a coup. Perhaps ironically, given fears of Chinese military expansionism, the PLA was perceived by New Zealand officials as the entity that could stabilise the revolution in China. Yet the state of Chinese civil-military relations was even less clear than how power and influence flowed inside the civilian leadership. The level of influence of any faction on the army was unclear, certainly in the first two years of the revolution, as was whether the PLA would act with unity or was as fractured as the body politic seemed to be. Given the attitude amongst External Affairs that the Cultural Revolution was a largely irrational exercise, or at least against the long-term interests of the Chinese state, it was generally assumed that the PLA would eventually tire of the chaos and restore order by force. It was left open as to whether this would be on the initiative of the military itself or following some faction of the political leadership interested in stemming the revolution.

Generally, the PLA was seen a faction in itself and acting in a unified if not always coherent fashion; it appeared as if the military took some time to decide how to handle the revolution. The relationship between the Red Guards and the PLA was not clear initially, but it soon appeared the guards were a nuisance to the military. Eventually the PLA would begin to support the province-by-province transition of power from the party to revolutionary committees. This confirmed the impression that the PLA was willing to support the

\footnotetext{
485 NZ Commission in Hong Kong, 9 January 1968, NYP 3/16/1 Vol 6, Political Affairs - China - General, ABHS W4628 6958 Box 46, ANZ
} 
revolution, although more to support a stable transition of power rather than radical action in support for or against Mao and his supporters.

At first, the American view shared with New Zealand was that the 'Red Guard' was a single paramilitary force with a 'reserve function' to the PLA. ${ }^{486}$ The Americans had heard reports that the Red Guards had been provided with training from PLA bases. While unsure if this was true, the Americans saw such training as a dangerous step toward anarchy and a sign of low confidence in the PLA. Around the same time Jiang announced that the PLA would take over maintenance of public security from the police. ${ }^{487}$ This followed Red Guard criticism of the commander of the Ministry of Public Security Xie Fuzhi. From the Indian Embassy in Beijing, the commission in Hong Kong understood that the Public Security Force had been dominated by supporters of Liu Shaoqi. However, Xie was a major supporter of the Cultural Revolution and would remain in his position as Minister for Public Security and would be elected chairman of the Beijing revolutionary committee when it was set up later in 1967.

The New Zealand High Commission in Canada saw the PLA as having an important function in supporting attacks by Red Guards aimed at the party:

The Red Guards... may have been created in co-operation between Lin [Biao] and Mao [Zedong] in the face of resistance in the Central Committee as a means of destroying resistance in the Party and of purging it without having to rely on the Army itself to do so. Certainly, after an initial stage in which they attacked individual citizens for 'bourgeois' tendencies, the Red Guard seem to have become primarily a weapon controlled lightly but fairly surely by the Army, which was directed at Party organs and officials at the level of the provincial and regional bureaux; as the movement developed, their attacks spread to individuals in the central organs in Peking where they remain concentrated at the present time. ${ }^{488}$

The use of the PLA to support revolutionaries in the creation of revolutionary committees to replace existing party-controlled local governments was considered by the commission to be a turning point in the revolution. ${ }^{489}$ The commission noted the Liberation Army Daily had on 25 January 1967 proclaimed that the army could no longer remain neutral. The same day the

\footnotetext{
486 NZ Embassy Washington to SecExternal, 10 January 1967, NYP 3/16/1 Vol 5, Political Affairs - China General, ABHS W4628 6958 Box 46, ANZ

487 NZ Commissioner in Hong Kong to SecEx, 12 January 1967, NYP 3/16/1 Vol 5, Political Affairs - China

- General, ABHS W4628 6958 Box 46, ANZ

${ }^{488}$ High Commissioner Ottawa to Acting SecEx, 18 January 1967, NYP 3/16/1 Vol 5, Political Affairs China - General, ABHS W4628 6958 Box 46, ANZ

489 Commissioner to SecEx, 8 February 1967, NYP 3/16/1 Vol 5, Political Affairs - China - General, ABHS W4628 6958 Box 46, ANZ
} 
Central Military Commission ordered all army units to support the revolutionaries where necessary. Mao was said to support the measure and prior to the announcement the PLA had already suppressed 300 'counter-revolutionaries' in Harbin. For the first time PLA units had appeared on the streets carrying arms. Counter to previous statements from the commission, it now suggested that the Mao-Lin group might be in the minority and Mao was understating rather than overstating the level of opposition. As the commission put it:

The fact that Mao has had to fall back on the support of the PLA may be regarded as a reflection of the inherent weakness and disorganisation of the revolutionary rebel red guard forces which he has endeavoured to forge as the instrument of his revolutionary vision of China's future. Mao may realize that the forces he has released are going to be very difficult to control, as indiscipline and excesses among the revolutionary rebel groups have been reported from many places. ${ }^{490}$

Associated with the wider question as to the extent to which Mao was in control of the revolution, was to what extent Mao would use the PLA to suppress the revolution if chaos and disorder went beyond what was in his interests. NZHC Ottawa thought Mao might be no more able to control the military than the complex web of competing revolutionary organisations. ${ }^{491}$ The view being shared by the Far Eastern Division of Canadian External Affairs was that Mao would not use the PLA to put down the revolution as this would be an admission of ideological failure and the army could be difficult to send back to their barracks once stability had been restored. NZHC Ottawa warned, along the lines of an article in the The Economist of 10 December 1966, that rivalries between the political and military establishments could be a further cause of destabilisation. ${ }^{492}$

The amount of support for the revolution in the PLA was never clear. The commission pointed to possible revolutionary activity in the PLA with the creation of a cultural revolution group in its command structure and Chinese military press warnings of reactionaries in the PLA leadership, which usually preceded denouncements ${ }^{493}$ Signs of the military's involvement in public life or in the maintenance of order were considered significant by several observers but not always for the same reasons. Increases in the

\footnotetext{
490 Commissioner to SecEx, 8 February 1967, NYP 3/16/1 Vol 5, Political Affairs - China - General, ABHS W4628 6958 Box 46, ANZ

491 NZHC Ottawa to SecEx, 24 January 1967, NYP 3/16/1 Vol 5, Political Affairs - China - General, ABHS W4628 6958 Box 46, ANZ

492 NZHC Ottawa to SecEx, 24 January 1967, NYP 3/16/1 Vol 5, Political Affairs - China - General, ABHS W4628 6958 Box 46, ANZ

493 NZ Commission Hong Kong to SecEx, 19 January 1967, NYP 3/16/1 Vol 5, Political Affairs - China General, ABHS W4628 6958 Box 46, ANZ
} 
military activity in the civilian sphere was cautiously seen by the Embassy in Washington and by some in the State Department as the military undermining Mao and supporting the party.

...some other China experts in the State Department have pointed out to us... that, despite the renewal of the campaign against Liu and [Deng] and other indications of revived activity among the extremists, the actual running of the country seems still to be in the hands of the Army and its collaboraters [sic] within the civilian bureaucracy. The feeling of these experts seems to be that, whatever, the superficial appearances may be, the reality is that power lies in the hands of the Army and is being exercised not to advance the Cultural Revolution but to maintain order and to keep the economy running more or less smoothly. ${ }^{494}$

This was part of a wider general assumption by the Americans and others that the military would try and maintain order regardless of whether it supported the wider aims of the revolution. ${ }^{495}$ Yet the commission saw the encroachment of the PLA into civilian affairs as a sign that the PLA was supporting the revolution rather than undermining it and that the PLA was fighting the party rather than propping it up:

The PLA is now deeply involved in the campaign; the Peoples Daily has in fact inferred that its support for the revolutionary rebels is the difference between victory and defeat. At first reluctant to commit the army in their support, Mao appears to have been finally forced to take this step, presumably because of the strength of the opposition. In announcing the army's full support for the proletarian revolutionaries, the Liberation Army Daily quoted Mao's dictum that political power grows out of the barrel of a gun. Another dictum of Mao's, that the party must always control the gun, not the gun the party, seems to have been conveniently forgotten. ${ }^{496}$

These positions were reflective of the commission's overall difference of opinion to the State Department. The revolution, in the commission's eyes, was under more control by the senior leadership than believed by the Americans. The State Department was more inclined to see events as chaotic and unpredictable; they thought Mao was riding out a storm into which he had intentionally sailed. Both saw greater involvement by the PLA as confirmation of their overall attitudes. To the commission the use of the PLA was an example of the leadership exercising their control over the situation, but to some in the State Department it

\footnotetext{
${ }^{494}$ NZ Embassy Washington to SecEx, NYP 12 April 1967, 3/16/1 Vol 5, Political Affairs - China - General, ABHS W4628 6958 Box 46, ANZ

495 NZ Embassy Washington to SecEx, 15 February 1967, NYP 3/16/1 Vol 5, Political Affairs - China General, ABHS W4628 6958 Box 46, ANZ

496 Commissioner to SecEx, 22 February 1967, NYP 3/16/1 Vol 5, Political Affairs - China - General, ABHS W4628 6958 Box 46, ANZ
} 
was more evidence of opposition to Mao's excesses. While the commission agreed Mao seemed to be 'riding the wave, and probably enjoying himself too', the commission could see signs of moderation in the Mao-Lin group. ${ }^{497}$

Another perceived source of tension in the PLA was a split between those who favoured traditional military professionalism and those more influenced by Mao's teaching on revolutionary warfare. Mao's approach placed greater emphasis on the mass army and on guerrilla warfare while minimising the role of expensive capital equipment, technological development, and the professional military leadership. For the British the split had ramifications for foreign policy as they thought the professionals in the PLA wanted better relations with the USSR in order to gain access to modern weapons but this was opposed by the Maoists with their 'emphasis on terrain, morale, mobility and guerrilla tactics' ${ }^{498}$ The Americans also noted this source of tension to New Zealand officials. ${ }^{499}$

As the revolution continued the PLA's involvement in internal security and civil administration grew and became more obvious to outside observers. With greater involvement in the running of the country the PLA brought itself into conflict with revolutionary organisations even while it facilitated the transfer of power from the party to revolutionary committees. The commission noted this tension and the attempts by the leadership to reconcile the PLA with the revolutionary masses. ${ }^{500}$ The role of the PLA in the revolution and its goals were perhaps even less clear to Western observers than the relationship between the factions in the Government, but it did have more influence on China's foreign policy. A military preoccupied with maintaining internal order was less likely to take part in foreign adventures. This helps explain China's decline as a military threat in the minds of New Zealand planners from 1968.

By 1968 the revolution was eighteen months old. The increase in the PLA's role was a sign of likely greater future stability in China and greater preoccupation of the Chinese military. The realisation among New Zealand defence officials that China posed less of a threat came

\footnotetext{
497 NZ Commission Hong Kong to SecEx, 19 January 1967, NYP 3/16/1 Vol 5, Political Affairs - China General, ABHS W4628 6958 Box 46, ANZ

498 NZHC London to SecEx, 30 January 1967, NYP 3/16/1 Vol 5, Political Affairs - China - General, ABHS W4628 6958 Box 46, ANZ

499 NZ Embassy Washington to SecEx, 22 March 1967, NYP 3/16/1 Vol 5, Political Affairs - China - General, ABHS W4628 6958 Box 46, ANZ

500 Commissioner Hong Kong to SecEx, 12 April 1967, NYP 3/16/1 Vol. 5, Political Affairs - China General, ABHS W4628 6958 Box 46, ANZ Commissioner Hong Kong to SecEx, 10 May 1967, NYP 3/16/1 Vol. 5, Political Affairs - China - General, ABHS W4628 6958 Box 46, ANZ
} 
just as the PLA worked to restore order and transfer power to revolutionary organisations. The PLA's facilitation of the transfer of power to revolutionary organisations would be an aspect of the revolution in which New Zealand observers, especially the Commission in Hong Kong, took great interest.

\subsubsection{New Organisational Structures and the Economy}

The revolution saw local Communist Party governance replaced by new revolutionary committees. This transfer of power would begin in early 1967 and take until late in 1968 to replace all the previous regional bodies. Initially the call was for revolutionary organisations to seize power but soon revolutionary committees were organised through a 'triple alliance' of revolutionaries, the PLA, and pro-revolutionary or rehabilitated former leaders from the party. The failed attempt to create a 'people's commune' in Shanghai, based on the Paris Commune of 1871, showed the difficulty in using revolutionary zeal alone to create new institutions. The commune's failure showed that revolutionary renewal of China's governance would require cooperation between the party, the military, and the revolutionary organisations.

The transfer of power would be easier in some places than others. Some provinces would experience a considerable amount of violence. New Zealand observers and their foreign colleagues were concerned that the transfer of power would cause an immense amount of strain on the Chinese state or cause severe damage to the economy. New Zealand officials and their foreign colleagues had little solid information on which to base their assessments of the Chinese economy. Their predictions for the Chinese economy were largely based on the assumption that the disorder of the Cultural Revolution would affect production. This was either through direct disruption of production or transportation, or through indirect effects such as through the need of workers to take part in revolutionary meetings and demonstrations.

The NZHC Ottawa noted the regionalism the revolution was creating. The high commission considered the effect of the revolution on China's structure to be unpredictable and thought extreme outcomes were possible. If a future government of national unity emerged, then it might have to be even more 'coercive and illiberal' in order to reaffirm Beijing's power. Alternatively, a decentralised state with a weak governing party but strong military was also 
foreseen as potentially more coercive and illiberal than the then current situation. ${ }^{501} \mathrm{By}$ comparison the NZHC London thought a civil war would be possible if the military became pressured by the decentralisation and split along regional lines. ${ }^{502}$ Following the failure in Shanghai, the Americans noted to New Zealand officials signs of Zhou's moderating influence on the transfers of power. The masses were still being encouraged to seize power, but they were told to choose their targets. As an example of the new directive, the new revolutionary organisation in Heilongjiang was staffed by mainly those from the old party structure with only a few being made scapegoats. ${ }^{503}$

The commission saw attempts at co-opting the PLA and sympathetic party elements into the new revolutionary committees as a way of consolidating and coordinating the revolution rather than halting it. ${ }^{504}$ The commission pointed to reports in the Chinese press of the takeover of local party committees by revolutionaries in the provinces of Shanxi, Guizhou, Heilongjiang, Fujian, and the cities of Shanghai and Qingdao. The Chinese press had been full of 'adulatory articles' on the action of revolutionaries in these areas and claims of accompanying increases in production. Local broadcasts had also claimed revolutionary takeovers in Anhui, Hubei, Jiangxi, Guangxi, and Shaanxi provinces but they had not been confirmed by officials in Beijing. The commission noted to Wellington an editorial from the People's Daily on 10 February 1967 which listed four factors that made the struggle in Heilongjiang a good example for proletarian revolutionaries. The revolutionaries had united with Mao's supporters amongst the leaders of the provincial party committee and with the PLA; they had seized media outlets to improve propaganda efforts prior to taking control of the provincial party committee; 'left forces' had united with 'middle forces' to attack 'most stubborn reactionary forces'; and had used Mao's thought to keep the struggle on the right path. ${ }^{505}$ The article said it was the combination of proletarian revolutionaries, PLA units, and pro-Mao supporters within the Party that was important in seizing power away from those who would take the 'capitalist road'. The People's Daily emphasised that existing party

\footnotetext{
501 NZHC Ottawa to Acting SecEx, 18 January 1967, NYP 3/16/1 Vol 5, Political Affairs - China - General, ABHS W4628 6958 Box 46, ANZ

502 NZHC London to SecEx, 30 January 1967 (3 $3^{\text {rd }}$ letter), NYP 3/16/1 Vol 5, Political Affairs - China General, ABHS W4628 6958 Box 46, ANZ

503 NZ Embassy Washington to SecEx, 15 February 1967, NYP 3/16/1 Vol 5, Political Affairs - China General, ABHS W4628 6958 Box 46, ANZ

504 NZ Commission Hong Kong to SecEx, 22 February 1967, NYP 3/16/1 Vol 5, Political Affairs - China General, ABHS W4628 6958 Box 46, ANZ, 22 February 1967

505 NZ Commission Hong Kong to SecEx, NYP 3/16/1 Vol 5, Political Affairs - China - General, ABHS W4628 6958 Box 46, ANZ, 22 February 1967
} 
leaders could and should remain in positions of responsibility if they stood with Mao, and those who had committed mistakes could be rehabilitated through re-education.

The commission noted that the seizure of power by revolutionaries was at different stages across the country and achieved much more easily in some areas than others: 'It is taking a long time... for a single spark struck in Shanghai to start the prairie fire'. ${ }^{506}$ In some areas the rebel committees had been set up and media outlets taken over, but the provincial and municipal party committees were still in command. Conflict and protest continued in some places where revolutionaries had taken complete control. The emphasis on unity in the Chinese press was taken by the commission as being a sign of the great difficulty in uniting the various revolutionary organisations to run the new provincial administrations. The commission had heard reports that Red Guard units in Beijing were refusing to work with other units to create a new revolutionary administration for the capital city. The disruption to the normal chain of command was also thought by the commission to have created confusion and hindered the consolidation of revolutionary forces. ${ }^{507}$

Outside observers worried the expansion of revolutionary activity to heavy industry and agriculture would place a significant strain on the state and the economy. The NZHC London thought that if Mao's campaigns were to be pressed in all sectors at once then the economy and the civil administration could grind to a halt, but this was not likely. ${ }^{508}$ The Commission in Hong Kong noted from January 1967 that the revolution was spreading to factories and the countryside. Like other commentators, the NZHC in Ottawa did not put any faith in the economic outcomes of Mao's revolution. Spreading the revolution to farms and agriculture was seen as particularity dangerous by the Canadians in their reports to the NZHC which were repeated to Wellington.

The economy of China has probably already suffered seriously from the activities of the Red Guard, from the gaps... in the ranks of able but ideologically 'undependable' specialists and technicians... and from the disorder which has apparently already been created in the production, distribution and communication sectors. If the recent decision to spread the Cultural Revolution to factories and farms is actively carried out, the paralysing effects on the economy would be much more widespread and pronounced; there are reports that this has begun. If the Mao-Lin group wins, their views are likely to be unconducive to the realistic, rational or effective development of the economic sector. If the group resisting them

\footnotetext{
506 NZ Commission in Hong Kong to SecEx, 8 February 1967

507 NZ Commission in Hong Kong to SecEx, 22 February 1967

508 NZHC London to SecEx, 30 January 1967 ( $3^{\text {rd }}$ letter), NYP 3/16/1 Vol 5, Political Affairs - China General, ABHS W4628 6958 Box 46, ANZ
} 
wins, we might expect more realistic and rational economic policies and practices. However, we do not know to what extent differences over economic policy lie at the root of the present struggle. In the absence of such knowledge it is difficult to predict what kind of policy shifts might result. ${ }^{509}$

A few months later the Canadians noted that the Chinese were able to fulfil all their export contracts and that exports to Hong Kong increased during major unrest in January 1967. Yet, they also noted reports of famine in Guizhou and disruptions to rail and port traffic. They concluded there was not any evidence that damage to Chinese industry caused by the revolution had reached 'critical proportions' ${ }^{510}$ NZHC London noted Zhou's calls to protect overseas trade by allowing goods to flow through ports and the free passage of mail and telegrams. Zhou had also urged the rebel organisations to resist taking over more organisations and to keep supervising the ones which they already controlled. ${ }^{511}$ The commission wrote of Zhou's successful attempts to get rival revolutionary organisations in Canton to agree not to disrupt the Canton Spring Trade Fair which was a major export business opportunity for the PRC. ${ }^{512}$ Generally, it appears that New Zealand's circle of observers did not find evidence of the economic disaster they predicted during the first months of the revolution, but this did not mean they saw any economic benefit to China from the revolution, simply that it had not done any major immediate damage.

The interest in China's economy could be seen as an attempt to gauge the extent of the revolution, with the assumption that revolution would be damaging to economic output. It was also an attempt to determine the stability of the Chinese state and its ability to fund the military. Economic predictions were not part of the defence assessments of 1965, but there was an assumption that China's power would grow into the late 1960s and 1970s. ${ }^{513}$ Trade with China during the Cultural Revolution was not yet on a such a scale that it was a major consideration of officials. That would start to change from 1970, but there was more of a focus on South East Asia than China. ${ }^{514}$ Even if the revolution did not damage the economy

\footnotetext{
509 NZHC Ottawa to Acting SecEx, 18 January 1967, NYP 3/16/1 Vol 5, Political Affairs - China - General, ABHS W4628 6958 Box 46, ANZ

510 NZHC Ottawa to SecEx, 28 April 1967, NYP 3/16/1 Vol 5, Political Affairs - China - General, ABHS W4628 6958 Box 46, ANZ

511 NZHC London to SecEx, 30 January 1967, NYP 3/16/1 Vol 5, Political Affairs - China - General, ABHS W4628 6958 Box 46, ANZ

512 NZ Commission Hong Kong to SecEx, 10 May 1967, NYP 3/16/1 Vol 5, Political Affairs - China General, ABHS W4628 6958 Box 46, ANZ

513 See Chapter 2: 'New Zealand Defence 1965-1970', DC 1/65, February 1965, MoD 1/1/2 Part 1

514 See Chapter 5: 'Size and Shape of the Armed Forces', Memo for Cabinet Defence Committee, 26 January 1970, MoD 1/1/2 Vol. 7, New Zealand Defence Policy - Review of Defence Policy, 1970
} 
to the extent that had been predicted initially, such assumptions helped break down the idea that China was a growing power. Certainly, External Affairs attempted to gain a comprehensive look at the situation in China and with so few reliable sources of information, any news was potentially meaningful.

Reports on China from diplomatic posts other than the Commission in Hong Kong slowed over the second half of 1967 and into 1968, but the commission continued to report on Chinese politics and the economy as well as the Hong Kong riots of 1967 which dominated events in the colony. Reports on mainland events from the commission were dominated by the transfer of power to the revolutionary committees. By June the commission was reporting that three-way alliances had been established in four provinces, and the cities of Beijing and Shanghai. Ten provinces were under military control, five had set up provisional organs of power, and the remainder were out of touch with the capital. ${ }^{515}$ While the commission continued to be confident of the ability of Beijing to place limits on the revolution, the Indian view had darkened by August 1967 and they were now envisioning the possibility of a return to the China of the 1920s where de facto control was in the hands of the provinces with limited de jure control in Beijing. ${ }^{516}$ Yet by the following year, and despite considerable violence reported by the commission, revolutionary committees had been established in twenty-four of the twenty-nine provinces. Only Yunnan, Tibet, Guangxi, Fujian, and Xinjiang remained and delegations from these provinces were in Beijing attempting to settle their differences. ${ }^{517}$

\subsection{ChInESE Foreign Policy}

China's foreign relations became particularly difficult in the first years of the revolution. Relations with much of the outside world became frozen if not openly hostile. Communist China's xenophobia became extreme as the Red Guards and officials alike viscerally denounced the bourgeois West and the revisionist Soviet bloc. As Henry Kissinger later put it:

China's diplomatic posture came unhinged. The world was treated to the nearly incomprehensible sight of a China raging with indiscriminate fury

\footnotetext{
515 Commission in Hong Kong to SecEx, 26 June 1967, NYP 3/16/1 Vol 6, Political Affairs - China General, ABHS W4628 6958 Box 46, ANZ

516 NZHC Delhi to SecEx, 24 August, 1967, NYP 3/16/1 Vol 6, Political Affairs - China - General, ABHS W4628 6958 Box 46, ANZ

517 NZ Commission Hong Kong to SecEx, 7 June 1968, NYP 3/16/1 Vol 7, Political Affairs - China General, ABHS W4628 6958 Box 46, ANZ
} 
against the Soviet bloc, the Western powers, and its own history and culture. ${ }^{518}$

The British Embassy in Beijing was sacked by Red Guards; its staff were harassed and denied exit visas for months. The Soviet embassy was subjected to noisy round-the-clock demonstrations to prevent its staff working or sleeping. Chinese diplomats across the world were recalled home for re-education and/or denouncement. Only Albania and a smattering of African nations maintained functional - let alone friendly - relations with Beijing during the late 1960s.

Observations of China during the early revolution were focused on domestic affairs due to the complex, tumultuous, and unprecedented nature of the revolution. Observations of foreign policy were pushed to the background for some time, but as the revolution went on diplomatic discussions of Chinese foreign policy by New Zealand's officials became more common and better informed. The question of Chinese support for North Vietnam and the likelihood of Beijing's intervention into the war was a major interest for New Zealand officials, as it had been for defence planners since 1965, but so was coming to grips with the major external pressures on China and how it was likely to react to them. While New Zealand's debates about China in the defence and diplomatic fields ran in separate streams, they both looked to understand the likelihood of China entering a major conflict. A major change in Chinese foreign policy had major implications for New Zealand's threat perceptions. As China's foreign policy shifted in 1968, so too did New Zealand's perception of threat. ${ }^{519}$

The extent of Beijing and Moscow's mutual hostility became more and more evident during this period as the idea that Beijing could seek rapprochement with the west to counter the Soviet threat crept slowly into New Zealand's diplomatic circles and built credence. Defence officials adjusted their views slightly later as Sino-Soviet relations continued to deteriorate. $^{520}$ However, some sense of stability in China was necessary before rapprochement was possible. Western countries needed to be assured that Beijing was capable of making stable and predictable foreign policy before there was a serious possibility of engagement with Beijing. Nevertheless, a China thrown into chaos was not a

\footnotetext{
518 Henry Kissinger, On China, Kindle Edition, Penguin, London, 2011. pp.193-194

519 The change is best seen in the debate in the Defence Council. See Chapter 3: Defence Council Minutes, DC/M/(68)9, 12 March 1968, MoD 1/1/2 Vol 3, Review of Defence Policy

520 'The Strategic Outlook for the Pacific Area: 1970-75 and Beyond', October 1970, JIC(NZ)(70)17, MoD 1/1/1, New Zealand Defence Policy - General, 1968-1972
} 
stable partner for diplomatic relations, but neither was it likely to be able to dominate South East Asia in the way New Zealand defence officials had once feared.

\subsubsection{External Pressures and Vietnam}

Much time was spent by New Zealand's diplomatic circles determining which external pressures were having an impact on Chinese politics and foreign policy. The Americans were much more convinced than the British that American action in Vietnam had been the external force responsible for the Cultural Revolution. The British meanwhile saw China's foreign policy failures elsewhere as boosting Mao's critics, causing him to initiate the revolution. In early 1967, the New Zealand Embassy in Washington summed up the differences:

There is one other point... with which experts here would agree but the Foreign Office may not, and this relates to the broad policy question... the Charge says "It seems probable that the setbacks in foreign policy suffered by China in 1965, e.g. the collapse of the Algiers conference and the debacle in Indonesia, will have stimulated Mao's critics." American observers would probably point out, however, that the strongest external stimulus has been that provided by the United States stand in Vietnam. By sending large numbers of troops to South Vietnam from July 1965 on, the Administration has, it is argued, revived the Chinese fear of an American invasion, and in so doing it has brought to a head differences over strategy... Analysts here also feel that the threat of invasion precipitated Mao's decision to launch the Cultural Revolution, for they point out that one of the justifications continually being advanced by the regime is the necessity to prepare for an American attack. These experts therefore maintain that, insofar as the present disarray in Peking is due to external factors, it is not the minor relaxations in Western policy towards China which have been responsible, but on the contrary the hard line which the United States has taken on the crucial issue of Vietnam. That there is a role for the carrot as well as the stick in getting the Chinese to adopt a more reasonable attitude, few here would deny; but there are not, as far as we are aware, very many in the United States Government who would agree that the West should rely primarily on relaxing its isolation and encirclement of China, and should do so before Peking is ready to adopt a more moderate line. ${ }^{521}$ (Original emphasis)

In other words, American experts thought American power in South East Asia had caused the revolution but a relaxation of that power was unlikely to generate a more cooperative response by Beijing. While this might have overstated American influence in the Cultural Revolution, such a view was compatible with New Zealand fears during 1965 of Chinese

521 NZ Embassy Washington to SecExternal, 3 January 1967, NYP 3/16/1 Vol 5, Political Affairs - China General, ABHS W4628 6958 Box 46, ANZ 
intervention in Vietnam which has been discussed above. ${ }^{52}$ Then the most serious concern was that the American escalation in Vietnam would trigger a Chinese intervention. ${ }^{523}$ By early 1967 confidence began to grow in the US and, to a lesser extent, in New Zealand that China would not intervene in Vietnam and the question had become what could be done to improve relations between China and the US. ${ }^{524}$

The Canadians also put some weight to the idea that events in Vietnam had helped spur the Cultural Revolution. They noted evidence of air raid drills, efforts to disperse the populations of large Chinese cities and other civil defence precautions which suggested the Chinese leadership was taking the threat from the US seriously. ${ }^{525}$ By contrast the British thought the revolution had little to do with China's 'external preoccupations'. ${ }^{526}$ They saw no immediate threat to Hong Kong or Vietnam. They considered the trouble in Macau to be caused by local issues. ${ }^{527}$ There had been troop movements in the west and north of the country but the British did not consider them to be a prelude to a clash with the USSR or with India. ${ }^{528}$

The Canadians were split as to whether the Cultural Revolution could be preparing the Chinese people for war and whether the leadership envisioned any 'external ventures'. ${ }^{529}$ The three possibilities for Chinese action given by the Canadians to the NZHC Ottawa were an attack on Macau, an attack on India, or an attack on Vietnam. Only an attack on Macau was thought to be remotely realistic and then only as the result of Red Guard excesses rather than as a planned offensive. Ottawa dismissed the idea of an invasion of Hong Kong: "events in the past months have shown the Chinese to be mad and irrational, but not that

${ }^{522}$ See Chapter 2, Section 6: Draft 'Review of New Zealand Defence policy up to 1970', January 1965, MoD 1/1/2 Part 1

${ }^{523}$ Perhaps best illustrated by Holyoake's message to Cabinet quoted at the start of Chapter 2: 'ANZUS Council Meeting, Washington, Report to Cabinet', 28 June 1965, ABHS W5422 950 Box 34, 111/3/3/15 Vol. 8, International Affairs: Security Pacific Pact, ANZUS Council Meetings, 1968-1970

524 This view took a while to grow and was well established by early 1968: Draft memo for Defence Council, c. February 1968, MoD 1/1/2 Vol 3, Review of Defence Policy

525 John Fraser, 'Looking Back at the Cultural Revolution', c. December 1967, in NZHC Ottawa to SecEx, 4 January 1968, NYP 3/16/1 Vol 6, Political Affairs - China - General, ABHS W4628 6958 Box 46, ANZ

${ }^{526}$ NZHC London to SecEx, 30 January 1967 ( ${ }^{\text {rd }}$ letter), NYP 3/16/1 Vol 5, Political Affairs - China General, ABHS W4628 6958 Box 46, ANZ

${ }^{527}$ Riots in Macau in December 1966 resulted in an agreement the following month which led to greater Chinese participation in the administration of the Portuguese colony. See: Cathryn Clayton, 'The Hapless Imperialist? Portuguese Rule in 1960s Macau' in (Bryna and David Goodman eds.) Twentieth Century Colonialism and China: Localities, the everyday, and the world, Routledge, 2012, pp. 216-219

${ }^{528}$ NZHC London to SecEx, 30 January 1967 (3 ${ }^{\text {rd }}$ letter), NYP 3/16/1 Vol 5, Political Affairs - China General, ABHS W4628 6958 Box 46, ANZ

${ }^{529}$ High Commissioner London to Acting SecExternal, 24 January 1967, NYP 3/16/1 Vol 5, Political Affairs China - General, ABHS W4628 6958 Box 46, ANZ 
mad" (original emphasis). ${ }^{530}$ While perhaps more hawkish in their discussions with New Zealand officials than some, the Canadians still considered the external stimulus on China was ideological rather than military and that the ideological stimulus had come from the USSR rather than American activity in South Vietnam.

The NZHC in Ottawa was not willing to make clear predictions itself on the future of Chinese foreign policy. It noted the hardening of Chinese foreign policy combined with a growing indifference on the part of China's leaders to the country's growing international isolation. The willingness on the part of those pushing the revolution was seen as a sign that the Chinese leadership did not believe 'the USA will force war on them'. ${ }^{531}$ Nor did the NZHC see any sign China was contemplating a military confrontation with the US over Vietnam. However, the NZHC warned (in the most qualified terms) that the irrationality seen in Chinese domestic policy could spill-over into an ill-considered military action.

Nevertheless, much that is quite irrational in practical terms has already been done by those who appear to be in the ascendancy in Peking, with serious domestic consequences; there is no reason to expect greater rationality in their assessment of the international consequences of their acts, and we cannot exclude the possibility, for example, that an act of desperation in protecting their threatened ascendancy may lead them to launch an external adventure of some sort, not inconceivably in the form of military confrontation with the USA. ${ }^{532}$

Ottawa was also concerned that Hong Kong might be a flash point for such an overreaction.

Molgat [at the Canadian Department of External Affairs] concluded by reiterating a remark that he had made to us previously and of which the Hong Kong disturbances are a graphic illustration - the present danger in Chinese foreign policy is not so much the likelihood of foreign adventures undertaken on official instruction as much as the possibility of an irrational response to alleged "provocation". It should not be lightly assumed that China's reaction to any event which the Chinese people might consider to be of significance will necessarily be guided by her own best interests. ${ }^{533}$

Regardless of how much weight observers placed on the idea of a foreign adventure by Beijing, it was generally agreed that the Cultural Revolution was largely inward looking.

${ }^{530}$ High Commissioner London to Acting SecExternal, 24 January 1967, NYP 3/16/1 Vol 5, Political Affairs China - General, ABHS W4628 6958 Box 46, ANZ

${ }^{531}$ High Commissioner Ottawa to Acting SecEx, 18 January 1967, NYP 3/16/1 Vol 5, Political Affairs - China - General, ABHS W4628 6958 Box 46, ANZ

532 High Commissioner Ottawa to Acting SecEx, 18 January 1967, NYP 3/16/1 Vol 5, Political Affairs - China - General, ABHS W4628 6958 Box 46, ANZ

${ }^{533}$ NZHC Ottawa to SecEx, 31 May 1967, NYP 3/16/1 Vol 5, Political Affairs - China - General, ABHS W4628 6958 Box 46, ANZ 
The US and UK both told New Zealand officials that if Mao and his successors were successful in imposing their will, then foreign policy would remain inflexible. ${ }^{534}$ China would not send large numbers of forces into Vietnam unless the security of China was threatened. However, the British - unlike the Americans - did not acknowledge the threat posed by Chinese subversion and Beijing's support for national liberation movements. Such an omission was viewed by Washington and the NZ Embassy there as being unbalanced, ${ }^{535}$ but soon after, the Secretary of External Affairs wrote to the NZHC in Delhi saying he thought Chinese foreign policy had been characterised by inactivity in both its diplomatic and subversive efforts. ${ }^{536}$ This shows that New Zealand views on the risk posed by Beijingbacked revolutionaries was beginning to change. ${ }^{537}$

In contacting Delhi, Laking was seeking the Indian view on 'Chinese territorial ambitions in its south-western border area'. ${ }^{538}$ The Indians did not share the secretary's view that Chinese foreign policy was inactive, but they did agree it had slowed down with fewer foreign communists visiting China. The Indians believed that Chinese foreign policy was continuing much as it had before the Cultural Revolution despite the return to China of many Chinese diplomats. The Indians noted that the Chinese had been active in Tanzania, Pakistan and Cambodia. Propaganda campaigns continued in Thailand and India. In the Indian view, China was looking to confirm its great power status and that it was the leader in promoting world revolution.

New Zealand officials asked if the Indians thought China was aggressive or simply looking to gain influence. In reply the Indians noted that China had showed restraint in Vietnam but its search for great power status would mean it would not like to be seen to be pushed around by either the Soviet Union or the United States. ${ }^{539}$ The Indians thought that it would suit China to establish a series of communist client states in South East Asia and there was

\footnotetext{
534 NZ Embassy Washington to SecExternal, 3 January 1967, NYP 3/16/1 Vol 5, Political Affairs - China General, ABHS W4628 6958 Box 46, ANZ

535 NZ Embassy Washington to SecExternal, 3 January 1967, NYP 3/16/1 Vol 5, Political Affairs - China General, ABHS W4628 6958 Box 46, ANZ

536 SecEx to NZHC Delhi 14 February 1967, NYP 3/16/1 Vol 5, Political Affairs - China - General, ABHS W4628 6958 Box 46, ANZ

537 See Chapter Five, Section 4.3: By 1971 External Affairs would take a much more philosophical approach to Beijing's support for revolutionary groups. Beijing's support started to look more and more rhetorical and less practical from the late 1960s: Commission to MinFA, 26 August 1971, ABHS W4628 6958 Box 46, NYP 3/16/1 Vol. 8, Political Affairs - China - General, 1971

538 SecEx to NZHC Delhi 14 February 1967, NYP 3/16/1 Vol 5, Political Affairs - China - General, ABHS W4628 6958 Box 46, ANZ

539 NZHC Delhi to SecEx, 22 March 1967, NYP 3/16/1 Vol 5, Political Affairs - China - General, ABHS W4628 6958 Box 46, ANZ
} 
no reason to abandon this programme. However, the Indians thought Chinese foreign policy was xenophobic and subconsciously driven by old ideas about the superiority of the Han people, the concept of the Middle Kingdom, and the inferiority of barbarians living on its periphery. Indian officials thought these attitudes were ideologically reinforced by the success of the Chinese Communists in defeating the Chinese Nationalists. These officials felt this should not be exaggerated and they were much more relaxed about the Cultural Revolution than their Western counterparts. They considered Western reports of the upheaval in China to be highly exaggerated. Despite the mass meetings, parades, and signs of mass hysteria, Indian officials considered the revolution to be well under the control of the Government, especially Zhou. In their view Zhou was keeping the revolution from affecting the administration in any significant way.

As Delhi suggested, there were signs that China would demonstrate its unwillingness to be bullied by the Soviets and the Americans. The New Zealand Embassy in Washington noted that for the first time the Chinese were warning both Washington and Moscow against taking advantage of the Cultural Revolution and that the Americans considered the Soviets a major military preoccupation for the Chinese. New Zealand officials were coming to realise that China saw the Soviets as a greater threat than the West. ${ }^{540}$

The threat [to China] may, moreover, be seen as coming more from the Russians than from the Americans. The former Japanese Foreign Minister, Kosaka, told the State Department after his visit to China in September that the factory managers and others he spoke to felt a much stronger and more personal antipathy to the Soviet Union than to the United States, and Donald [the Deputy Director of the US State Department Office of Asian Communist Affairs] thought that this is probably true of most of the managerial class in China, including its military members. It is unlikely that even Mao would take the irrational step of actually launching a foreign adventure, whether in Vietnam or against the Soviet Union, but it is by no means inconceivable that Peking leadership may deliberately play up the Soviet bogey to strengthen its position at home, and in fact it seems to have been doing so in the last couple of weeks. ${ }^{541}$

Unlike Mao and the other revolutionary leaders, Zhou's rationality was never questioned. Throughout the turbulent years of 1966-1968, Zhou was consistently viewed by almost every observer in New Zealand's diplomatic circles as actively moderating the revolution

540 See Chapter 5 for more on the deepening of the Sino-Soviet Split. External Affairs noted the importance of the split publicly in 1969: 'China's calm not sign of friendship', Information and Press Section, Publicity Division, 15 May 1969, ABHS W4627 Box 4072 264/4/1 Vol. 22, China: Political Affairs - General 196869

${ }^{541}$ NZ Embassy Washington to SecEx, 15 February 1967, NYP 3/16/1 Vol 5, Political Affairs - China General, ABHS W4628 6958 Box 46, ANZ 
and its effects on Chinese foreign policy. However, the figures seen by outside observers to be opposing the revolution were not necessarily considered to be more inclined towards détente than the revolutionaries. In March 1967 the NZHC London noted that The Economist, unnamed American scholars, and the Far Eastern Department of the UK Foreign Office, were of the opinion that the 'revisionist' group of Liu and Deng favoured a tougher policy towards the Vietnam War. ${ }^{542}$ This posed the awkward possibility that those opposed to the revolution wanted to challenge the Americans in Vietnam even more than those advancing the revolution and that stability in Chinese politics might not bring better relations with the West.

Expectations of Chinese intervention in Vietnam were dampened by strains in Hanoi's relationship with Beijing. The Americans were seeing signs of Hanoi's independence from Beijing. The State Department told New Zealand officials of its confidence that Beijing would not intervene in Vietnam unless at Hanoi's request, a request the Americans were now confident Hanoi would not make. It seemed to the State Department that Hanoi was afraid of China but the North Vietnamese were concerned about a political rather than military intervention in Vietnam. ${ }^{543}$ Hanoi's publication of letters between President Lyndon Johnson and Ho Chi Minh on the conditions for peace talks was seen by the State Department as a means of limiting Beijing's influence, but it also delayed making such talks possible. Yet, a diminishing of Beijing's influence on Hanoi was seen as positive from a US perspective, ${ }^{544}$ with the Americans hoping for a Sino-Vietnamese split to match the Sino-Soviet split. This contrasts strongly with earlier New Zealand defence assumptions that implicitly assumed Hanoi and Beijing were more monolithic. 545

Zhou confirmed in April 1967 that China would intervene in Vietnam if Hanoi asked for it, or if China's own security was threatened. Chen Boda added a third trigger: an attempt by the United States and the Soviet Union to impose a settlement of the conflict which "betrayed" the interests of North Vietnam. An American landing in North Vietnam or the overthrow of the North Vietnamese regime was considered by the US to be unacceptable to the Chinese. However, while looking at these statements, Donald at the US State Department wondered privately to his New Zealand counterparts whether the American

\footnotetext{
${ }^{542}$ NZHC London 9 March 1967

${ }^{543}$ NZ Embassy Washington to SecEx, 27 February 1967, NYP 3/16/1 Vol 5, Political Affairs - China General, ABHS W4628 6958 Box 46, ANZ

${ }^{544}$ NZ Embassy Washington to SecEx, 12 April 1967, NYP 3/16/1 Vol 5, Political Affairs - China - General, ABHS W4628 6958 Box 46, ANZ

${ }^{545}$ See Chapter 2, Section 6
} 
bombing of North Vietnam could lead to Chinese intervention in an air war which could then escalate further. However, he thought the Chinese were still taking a cautious approach and focused on their internal problems; there was still no sign of a resurgence in Chinese interest in foreign policy. ${ }^{546}$

Slight changes were noticed the following month when the commission noted an upswing in Chinese press statements on foreign policy issues. These showed the dangerous paranoia that China was experiencing in its relations with much of the outside world, especially the Soviet Union. ${ }^{547}$

Throughout the period of the cultural revolution, the Chinese have of course frequently made bitter and vehement attacks on the Soviet Union, and the stated purpose of the cultural revolution after all [sic] is to prevent China from following the revisionist road. Recently the Chinese press has come out with a rash of editorial statements and articles on foreign affairs and in particular on events in Indonesia, the Congo, Aden, and India. The underlying theme of these statements has been the allege collusion of the U.S. imperialists, Soviet revisionists and local reactionaries in the global "holy alliance" against China. ${ }^{548}$

The Americans could see that they had similar interests to the Soviets in South East Asia, especially in regards to limiting Chinese influence in the region. ${ }^{549}$ However, this was tempered with a feeling that greater Soviet influence in the region would also be against American interests.

The greater involvement of the PLA in public life in the first half of 1967 did not improve American confidence in assessing Chinese willingness to intervene in the Vietnam conflict. The State Department was unsure as to the effect of an effective military takeover in China on Beijing's Vietnam policy. ${ }^{550}$ The PLA could be pleased to see the US bogged down in Vietnam and willing to continue supporting North Vietnam as it had done, but it might also be less ideologically focused than the political class and thus more inclined towards intervention. However, the overriding presumption was that the policy of non-intervention would be maintained and the risk of escalation would decline.

\footnotetext{
546 NZ Embassy Washington to SecEx, 12 May 1967, NYP 3/16/1 Vol 5, Political Affairs - China - General, ABHS W4628 6958 Box 46, ANZ

547 Commissioner to SecEx, 25 April 1967, NYP 3/16/1 Vol 5, Political Affairs - China - General, ABHS W4628 6958 Box 46, ANZ

548 Commissioner to SecEx, 25 April 1967, NYP 3/16/1 Vol 5, Political Affairs - China - General, ABHS W4628 6958 Box 46, ANZ

549 NZ Embassy Washington to SecEx, 28 May 1968, NYP 3/16/1 Vol 6, Political Affairs - China - General, ABHS W4628 6958 Box 46, ANZ

550 NZ Embassy Washington to SecEx, 22 March 1967, NYP 3/16/1 Vol 5, Political Affairs - China - General, ABHS W4628 6958 Box 46, ANZ
} 
The New Zealand officials in Washington felt that the level of irrationality in Chinese foreign policy stopped well short of causing an intervention in the Vietnam War. ${ }^{551}$ Yet they also noted that Mao was being circumspect in regards to Vietnam whereas the 'alleged pragmatists' such as Liu and Luo Ruiqing (a PLA general under heavy criticism) were thought by the New Zealand Embassy to favour intervention in Vietnam and rapprochement with the Soviets. ${ }^{552}$ The New Zealanders thought Mao's reluctance to intervene in Vietnam could be both ideological and practical.

Mao's ideology made him opposed to this [intervention in Vietnam]: it is, after all, a basic article of his creed that a war of national liberation must be fought by the people of the country concerned. But this ideological position may well have been reinforced by a recognition of the dangers which a direct confrontation with the United States would involve dangers beside which those in the cases of Hong Kong and Burma pale into insignificance. ${ }^{53}$

Despite the signs of restraint in Hong Kong, the Americans were increasingly seeing Chinese foreign policy as irrational and unpredictable. In a change from their arguments of seven months prior, ${ }^{554}$ the Americans now saw foreign policy as a direct result of the internal pressures China was facing and not of any specific external pressure. The bellicosity of Chinese diplomatic rhetoric was seen by the Americans not so much as a tool to distract a domestic audience from internal problems, but as an earnest expression of the xenophobia and ideology produced by the revolution. This made the Americans very concerned about the possibility of a Chinese military adventure as China foreign policy now appeared to be based on ideological fervour rather than a sober accounting of China's long term interests. ${ }^{555}$ The difficulty in following the rapid pace of events in China and the swings of opinion amongst allies was not a solid basis to make foreign policy. Laking sought to find the limits of any extremism and the source of the unpredictability of Chinese foreign policy by looking at Beijing's policies towards Hong Kong, Nepal, Burma, and overseas ethnic

\footnotetext{
551 NZ Embassy Washington to SecEx, 5 July 1967, NYP 3/16/1 Vol 6, Political Affairs - China - General, ABHS W4628 6958 Box 46, ANZ

${ }^{552}$ NZ Embassy Washington to SecEx, 5 July 1967, NYP 3/16/1 Vol 6, Political Affairs - China - General, ABHS W4628 6958 Box 46, ANZ

${ }^{553}$ NZ Embassy Washington to SecEx, 5 July 1967, NYP 3/16/1 Vol 6, Political Affairs - China - General, ABHS W4628 6958 Box 46, ANZ

554 NZ Embassy Washington to SecExternal, 3 January 1967, NYP 3/16/1 Vol 5, Political Affairs - China General, ABHS W4628 6958 Box 46, ANZ

555 New Zealand Embassy Washington to SecEx, 27 July 1967, NYP 3/16/1 Vol 6, Political Affairs - China General, ABHS W4628 6958 Box 46, ANZ
} 
Chinese communities. ${ }^{556}$ He noted the takeover of the Chinese Foreign Ministry by the revolutionaries and the delicate balance between the Zhou's moderate and experienced influence and that of the radicals who had limited knowledge of foreign affairs. Laking assumed that the radicals were looking for a showdown with the British over Hong Kong and that Beijing's 'backtracking' when the riots risked involving China directly was caused by the moderates winning the argument over Hong Kong. However, in Laking's mind, Burma, Nepal, and Mongolia were further away from Chinese interests than Hong Kong and Vietnam and so the extremists could be allowed greater influence in those areas without harming China's core concerns.

It would, we feel, be going very far to infer from the incidents in China's neighbour[ing] countries that the Chinese, even under the stimulus of revolutionary zeal, would be prepared to move on to action in Vietnam. [Zhou] En-lai and the moderate element, more experienced in foreign affairs, doubtless realise that in Vietnam, wider issues, including the risk of nuclear war, are involved. They would consequently be more ready to wield all their influence to prevent any rash action instigated by the zealots which might spark off a major war. ${ }^{557}$

Laking felt that since Vietnam was not connected directly to the disputes over the Cultural Revolution, Zhou had more room to manoeuvre on this issue with his more extreme colleagues. Zhou could set a course of action on Vietnam that took into account these political and military realities without inspiring the wrath of the revolutionaries. ${ }^{558}$ Laking concluded that without an imminent military threat to China or an existential threat to North Vietnam, the Chinese leadership would not embark on a clash with the United States.

While it was still possible China could overreact to an incident, Laking thought that China would continue its 'oscillation between irrationality and restraint' in its foreign relations and in its domestic policy. In Laking's view the revolution had not affected national projects such as its nuclear weapons development. The outcome of the revolution was still unclear to Laking but the conditions that made the Chinese leadership wish to avoid confrontation with the US were still in place. Laking was less certain on how easy it might be for revolutionary zeal to upset those conditions which made conflict undesirable and move China a 'gigantic

556 Laking (SecEx) to New Zealand Embassy Washington, 4 August 1967

557 SecEx to NZ Embassy Washington, 4 August 1967, NYP 3/16/1 Vol 6, Political Affairs - China - General, ABHS W4628 6958 Box 46, ANZ

558 SecEx to NZ Embassy Washington, 4 August 1967, NYP 3/16/1 Vol 6, Political Affairs - China - General, ABHS W4628 6958 Box 46, ANZ 
step' from irritations with small neighbours to a major war. Laking acknowledged that the range of possibilities for the future of China were broad and a careful watch was necessary.

We fully agree with the State Department's comment that it is necessary, now more than ever, to keep a careful watch on Chinese actions and upon the movement of China's military forces. No one can be sure that [Donald's] assessment of Chinese motivations and objectives is accurate. It would be sensible, even though one might continue to believe that China will be careful not to provoke an international crisis which would place its own survival at stake, to continue hoping for the best while unobtrusively preparing for the worst. ${ }^{559}$

The Canadians were in agreement with Laking's perspective, although they were sceptical that the Chinese nuclear programme was advancing during the revolution. ${ }^{560}$ Like the Canadians, Australian officials were largely in agreement with Laking's analysis of Chinese foreign policy. However, they were less convinced about China's restraint in Hong Kong. Canberra considered the lack of Chinese guerrilla action in Hong Kong was due to a lack of 'revolutionary development' in the colony compared to South Vietnam and, for that moment, Beijing was focusing on material and propaganda support for Hong Kong communists and biding their time rather than limiting their goals.

\subsubsection{The Softening of Chinese Foreign Policy}

From late 1967 signs of Beijing's softening attitude to the outside world began to appear to New Zealand officials and their foreign colleagues. This would start with a general stabilisation of Chinese foreign policy and increased activity with the few friends Beijing had maintained during the revolution. This quickly led Western officials to speculate about the possibility of the rapprochement that would follow in the early 1970s. There was clearly a pent-up demand for better relations with China amongst New Zealand's closest partners. This is not surprising given the military difficulties they were having in South East Asia. As time went on wishful thinking for better relations seemed to become more common than pessimism that a military confrontation could occur. In August 1967 the chairman of the British JIC (FE) believed that the goals of Chinese foreign policy had not changed because of the revolution, but moderation might give way in the longer term.

\footnotetext{
559 SecEx to NZ Embassy Washington, 4 August 1967, NYP 3/16/1 Vol 6, Political Affairs - China - General, ABHS W4628 6958 Box 46, ANZ

560 NZHC Ottawa to SecEx, 16 August 1967, NYP 3/16/1 Vol 6, Political Affairs - China - General, ABHS W4628 6958 Box 46, ANZ
} 
China was in a militant, expansionist and aggressive mood. China would not attack anyone directly but it would not hesitate to stir up trouble and support subversion wherever possible. Its aims were first presumably to spread the Communist gospel, second to restore its traditional sphere of influence in South-east Asia and third to secure compliant governments in the states on its borders.

The first of these aims might lose its fervour as the revisionists gained control; and they might do this more quickly than expected, partly because today's revolutionaries become tomorrow's revisionists, but also because it would be in the way of things for today's revisionists to regain the edge in the current struggle. In ten years or so China might be much more ready to adopt a policy of peaceful coexistence. The second and third of China's aims were virtually inevitable in the long run, however much China was at present cutting herself off from the mainstream of international relations. ${ }^{561}$

This view harkened back to New Zealand's fears of Chinese expansionism in $1965,{ }^{562}$ but unlike that view, this prediction assumed that an outward looking China would be interested in peaceful coexistence. Such a peaceful co-existence would have big defence planning implications as it would represent a major decline in the risk of war.

New Zealand officials in Canberra noted that China's isolation was only tempered by the maintenance of relations with several emerging African nations. One area of Chinese foreign policy unaffected by the revolution was Chinese foreign aid, especially to friendly African nations such as Congo (Brazzaville), Guinea, Tanzania, and Somalia. The NZHC Canberra saw these relationships as the start of a wider softening of Chinese foreign policy and a greater interest in the outside world.

As China progressively withdraws into a position of hysterical hostility towards nearly all governments not slavishly conforming to the Maoist standard, the exceptions become the more prominent. It would seem that powerful influences in Peking are able to protect the relationship with certain African countries. In this connection it may be of particular interest to Australia that those African regimes with whom not merely a status quo, but a forward-moving, relationship is indicated from the evidence available here, command the western seaboard of the Indian Ocean and the entrance to the Red Sea. ${ }^{563}$

561 NZHC Singapore to SecEx, 5 October 1967, NYP 3/16/1 Vol 6, Political Affairs - China - General, ABHS W4628 6958 Box 46, ANZ

${ }^{562}$ See Chapter 2, Section 11, which outlines the views of the Secretary of Defence and the chiefs on the power of China.

${ }^{563}$ NZHC Canberra to SecEx, 17 October 1967, NYP 3/16/1 Vol 6, Political Affairs - China - General, ABHS W4628 6958 Box 46, ANZ 
By December 1967 it looked as though moderate forces were back in control of the Foreign Ministry. Chen Yi was thought by the Canadians to be back in control of the Foreign Ministry having been rehabilitated and reappearing in public having lost a considerable amount of weight. Revolutionary groups were told by the Central Committee that foreign diplomats were not to be interfered with and they were to be kept safe. ${ }^{564}$ However, this was not a sign that Maoist principles had been abandoned. This tension was noted by the Canadians.

There is, and has always been, a schizophrenic aspect to China's foreign policy. The urge for a revolutionary foreign policy carried out in defiance of conventional diplomatic methods has always been present. So has the yearning for an international respectability and recognition to give some substance to the oft-repeated claim "We have friends all over the world". ${ }^{665}$

Such a tension was seen even in individuals with Zhou, the moderate, calling for revolution in Africa and the extremist Jiang Qing criticising the Red Guards for harming China's international reputation by attacking embassies. Nevertheless, there was a feeling, especially amongst the Canadians, that this tension could be navigated by Western countries. The Canadian Trade Commissioner saw the possibility of improving relations.

It is also possible that China will come to show more interest in developing her relations with countries like Japan, Italy and Canada, in order to expand her visible circle of friends. Chinese, even at a rather low level, seem to be aware that the cultural revolution has given them a bad press in the rest of the world, and even the enthusiasts amongst the Chinese leadership may see some value in providing the Chinese people with some reassurance in the form of visibly improved relations with some other nations. ${ }^{566}$

By March 1968 change in Chinese foreign policy was more evident. ${ }^{567}$ Chen Yi was apparently considering an overseas trip. The New Zealand Embassy in Washington thought few countries would have welcomed a Chinese Foreign Minister in 1968 but they did not believe that any trip would have been possible six months earlier. Nevertheless, challenges

\footnotetext{
564 NZHC Ottawa, 17 December 1967, NYP 3/16/1 Vol 6, Political Affairs - China - General, ABHS W4628 6958 Box 46, ANZ

565 John Fraser, Canadian Trade Commissioner, 4 December 1967, in NZHC Ottawa to SecEx, 12 December 1967, NYP 3/16/1 Vol 6, Political Affairs - China - General, ABHS W4628 6958 Box 46, ANZ

566 John Fraser, Canadian Trade Commissioner, 4 December 1967, in NZHC Ottawa to SecEx, 12 December 1967, NYP 3/16/1 Vol 6, Political Affairs - China - General, ABHS W4628 6958 Box 46, ANZ

567 NZ Embassy Washington, 6 March 1968, NYP 3/16/1 Vol 6, Political Affairs - China - General, ABHS W4628 6958 Box 46, ANZ
} 
still remained, including the fact British diplomatic staff were still forbidden from leaving China. ${ }^{568}$

As revolutionary pressures faded, longer term challenges were brought back to the fore. Donald told the New Zealanders that the Americans had resumed talks with the Chinese in Warsaw. These talks were no more productive than they had been before the revolution but now the Americans felt the Chinese delegation had abandoned their revolutionary extremism and the historic roadblock of the status of Taiwan had returned as the core blockage in improving relations between the US and China. The New Zealanders noted that 'some' had taken this as sign of a Chinese desire for rapprochement but Donald thought it was simply the end of the revolutionary extremism and a return to the impasses of the past.

Even during the Johnson Administration, the New Zealanders noted a desire on the part of the Americans to improve relations with China and establish a much more distant form of containment. Donald's colleague at the State Department, William Bundy, made public statements which, to the New Zealanders in Washington, were a signal by the US to moderates in Beijing that good relations with the US were possible and that the US was not 'obdurately hostile to Communist China'. ${ }^{569}$ The US needed better relations with China if it were to disengage from military entanglements in Asia and this was understood by the New Zealanders in Washington.

Donald evidently does not envisage the continuation of the containment policy in quite the same form as it has taken in the past... [Donald said recent comments by senior White House officials were to] paint a picture of an Asia less ridden by tension than it has been in recent years - an Asia in which the United States was still involved, but involved less, because the countries of the area were themselves more viable. The aim was, in effect, to show the Chinese that there is nothing ineluctable about the conflict between the United States and Communist China: that if they are prepared to live in peace so are the Americans... The case for making such gestures is based on the assumption that sooner or later Peking will be forced to come to terms with realities and adopt a more pragmatic approach. ${ }^{570}$

Donald is making it clear that American policy - even before Richard Nixon's election was heading towards a less engaged form of containment and a more relaxed attitude

\footnotetext{
568 NZ Embassy Washington to SecEx, 6 March 1968, NYP 3/16/1 Vol 6, Political Affairs - China - General, ABHS W4628 6958 Box 46, ANZ

${ }^{569}$ NZ Embassy Washington to SecEx, 6 March 1968, NYP 3/16/1 Vol 6, Political Affairs - China - General, ABHS W4628 6958 Box 46, ANZ

570 NZ Embassy Washington to SecEx, 28 May 1968, NYP 3/16/1 Vol 6, Political Affairs - China - General, ABHS W4628 6958 Box 46, ANZ
} 
towards China. Donald's point that the states of South East Asia were more viable was not shared by New Zealand officials. Nevertheless, the Americans and New Zealanders were facing the same political reality that a significant military effort in South East Asia was not sustainable domestically or militarily.

\begin{abstract}
Donald felt that in order to feed their increasing population the Chinese will have to concentrate their efforts on internal economic development and give up, for the time being, their desire to become a great nuclear power. We questioned whether they would do this: Is not the desire for power central to the Chinese outlook? Is the idea of the Middle Kingdom not fundamental? Donald did not disagree, but he thought that through Marxism the Chinese have absorbed enough of Western values to see these goals in humanitarian terms... Whatever their ancestors may have done the present-day leaders are not, he thought, prepared to see people starve by the million so that they may have power. And there is thus a reasonable chance that if the olive branch is held out to them they will sooner or later take it. ${ }^{571}$
\end{abstract}

This view was not universal in the United States. The embassy in Washington thought comments by Secretary of State Dean Rusk suggested a more sombre attitude on the possibility of rapprochement with China and the embassy thought this attitude was shared by many Americans. However, Donald's optimism was also thought to be widespread.

By mid-1968 the commission noted that Chinese foreign policy seemed to be returning to normal. The northern summer was the traditional time for foreign delegations to travel to Beijing and by June 1968 the season had already seen visits by ministers from Mali, Guinea, and Nepal with the President of Tanzania due to arrive in the capital in a fortnight. It was rumoured that Zhou would visit Cambodia that year. The previous two years of the Cultural Revolution had only seen one foreign visit by a senior Chinese leader. ${ }^{572}$ The rebuilding of Chinese foreign policy was now undeniable and would continue as China looked to build better relations with the outside world to counter the Soviet threat.

\title{
4.5 CONCLUSION
}

The early period of the Cultural Revolution coincided with the breakdown of the containment strategy which had provided the framework for New Zealand's defence policy since the early 1950s. By the end of 1968 that framework still existed but its irrelevance was

\footnotetext{
${ }^{571}$ NZ Embassy Washington to SecEx, 28 May 1968, NYP 3/16/1 Vol 6, Political Affairs - China - General, ABHS W4628 6958 Box 46, ANZ

572 NZ Commission Hong Kong to SecEx, 5 June 1968, NYP 3/16/1 Vol. 7 Political Affairs - China - General 1968-1971, ABHS W4628 6958 Box 46, ANZ
} 
evident due to the lack of support from the US and UK. The loss of great power support for the containment of China in South East Asia removed New Zealand and Australia's means of containing China. However, the Cultural Revolution undermined the assumptions about China which underpinned the containment strategy. China was no longer a growing power. The ability of the CCP to unify the country and expand its economic and political power had been tested and it had failed. China had degenerated into a semi-controlled chaos which had increased Mao's personal prestige but had severely damaged the Chinese state and its reputation abroad. The idea that China had a political and economic system which the people of South East Asia might like to emulate was losing its credibility. The failure of the communist riots in Hong Kong showed the limits of Beijing's ideological influence on offshore Chinese. Meanwhile Beijing's refusal to provide material support to Hong Kong communists demonstrated the ability of the Chinese leadership to prevent the revolution's hostility to the West escalating dangerously.

With no diplomatic representation on the Chinese mainland, External Affairs' understanding of the Cultural Revolution was based largely on information from friendly nations and the international media. New Zealand's diplomatic discussion circle for the revolution was not large but External Affairs was well placed to keep a close eye on events in China albeit via intermediaries. Washington, London, and Ottawa were the capitals that provided the bulk of the information on China to New Zealand diplomats, both written and through face-to-face meetings. Paris and Delhi provided additional sources and perspectives that were often quite different from those of the Anglosphere. It also is evident that New Zealand did not take the word of its Anglo partners blindly and tried to look to as many sources as possible. The relative lack of input from other missions such as Canberra, Tokyo, Singapore, and Kuala Lumpur is surprising but is not necessarily meaningful as this may be a reflection of document management by External Affairs or haphazard declassification of files rather than an absence of diplomatic activity.

What is unsurprising is the New Zealand Commission in Hong Kong's predominance on Chinese issues in External Affairs. Unlike the other missions the commission dealt with Chinese issues on a daily basis and was more confident in its analysis of events on the mainland. The commission's view was of a revolution that was violent and chaotic but ultimately corralled by a leadership that was capable of moderation and practicality when necessary. This view was heavily influenced by information coming from Beijing but also by violence in Hong Kong and Guangdong. The commission's access to the British Embassy 
in Beijing and the mainland press gave New Zealand as good an insight into events in China as it could have without a diplomatic presence in Beijing.

The revolution did not make China seem friendlier to New Zealand in the eyes of officials. By the end of 1968 China had not softened its ideological attacks on the West or the Sovietbloc but it was no longer perceived to be the growing threat to New Zealand's interests in South East Asia it had been. Beijing's retreat from isolationism was only just beginning in 1968 and time still had to pass before diplomatic recognition of Communist China would be realistic or politically acceptable to the New Zealand public. However, it was the revolution that seemed to be containing China within its borders more than SEATO ever could have. As China's foreign policy stabilised and it sought better relations with the West, a new way of handling China would emerge, one where diplomatic engagement was not only possible but necessary to meet New Zealand's interests. That path was not obvious at the start of 1969 but with the failure of containment there was little else for New Zealand to do than find a modus vivendi for it and China. 


\section{FROM CONTAINMENT TO RECOGNITION}

We are in no hurry to take our seat in the United Nations, just as we are in no hurry to establish diplomatic relations with the United States. We adopt this policy to deprive the United States of as much political capital as possible and put it in the wrong and in an isolated position ... The longer you stall, the more you will be in the wrong and the more isolated you will become in your own country and before world opinion. - Mao Zedong, 18 January $1957^{573}$

\subsection{INTRODUCTION}

The years 1969 to 1972 marked a major shift in China policy culminating in the normalisation of New Zealand's relations with China. By 1969 Wellington viewed containment as a military strategy which, if not dead, was living on borrowed time. The British withdrawal and the American quagmire in Vietnam had made the breakdown of direct containment evident by the middle of 1968. Nixon's election promise of 'peace with honour'574 and the Guam Doctrine of July 1969 further confirmed that Washington was unprepared to enter another military adventure on the Asian mainland. China was still emerging out of the most disruptive phase of the Cultural Revolution and beginning to improve its relations with the world.

In 1969 Nixon's visit to China was still some way off, but with relations between Moscow and Beijing descending to the point of dangerous border skirmishes, ${ }^{575}$ it became clear to some in New Zealand - like Secretary of External Affairs George Laking - that a SinoAmerican rapprochement was likely. ${ }^{576}$ For New Zealand such a rapprochement was becoming the ideal outcome as the Government was looking to cut defence costs. With containment (as it was envisioned in the mid-1960s) no longer possible, new ways of dealing with China needed to be found. China was still thought hostile, but by the start of the 1970s Beijing was beginning to look willing to adopt a more conventional foreign policy

\footnotetext{
573 Mao Zedong, 'Talks at a Conference of Secretaries of Provincial, Municipal and Autonomous Region Party Committees', 18 January 1957, in Selected Works, v. 1, Beijing, Foreign Languages Press, 1977, p. 363.

574 While Nixon would later use this exact phase in 1973 (http://www.presidency.ucsb.edu/ws/?pid=3808), his 1968 campaign television commercial stated "I pledge to you that we shall have an honourable end to the war in Vietnam”, http://www.livingroomcandidate.org/commercials/1968/vietnam

575 Y. Kuisong, 'The Sino-Soviet Border Clash of 1969: From Zhenbao Island to Sino-American Rapprochement', Cold War History, Vol. 1, No. 1, 2000, pp. 21-52

576 George R. Laking, 'International Problems Confronting New Zealand in the 1970s', in Bruce Brown (ed.) New Zealand and Australia: Foreign Policy in the 1970s, Price Milburn, 1970, p. 25
} 
in which Western countries like New Zealand could have some kind of productive direct diplomatic relationship.

This is not to say that New Zealand implemented an organised strategy which took it from containment to diplomatic recognition; the period in between was largely one of trepidation and caution, if perhaps not incoherence of policy. The situation was fluid and China's relationship with the outside world, especially with the West, was changing rapidly. New Zealand was not a leader in this change, nor was it a complete follower waiting on orders from Washington, London, or Canberra. Wellington tried to keep its options open, trying not to box itself into a corner when the establishment of relations with China and Beijing's admission to the UN were perceived as inevitable. New Zealand needed to make the best of the situation and come to terms with China in the most advantageous manner and with the least risk of embarrassment.

As China emerged from the depths of the Cultural Revolution in 1969, two policy decisions for New Zealand were brought to the fore: whether to vote for the PRC's admission to the United Nations and whether to accord the communist state diplomatic recognition and create official ties. While linked, these issues were handled somewhat separately. Both questions were made complicated by the visceral mutual loathing between the two states claiming to represent the Chinese people, the PRC and the Republic of China. One's existence was an affront to the other and neither would allow any form of mutual recognition. This forced other nations to break diplomatic ties with one of these entities if it chose to establish relations with the other. This made the possibility of both Chinese states being represented in the UN extremely difficult.

The lack of willingness to compromise meant that the PRC would not enter the UN or gain widespread recognition until it had sufficient influence to force governments to abandon their relations with Taiwan. This tipping point came in 1971 as Beijing's new enthusiasm for foreign relations began to bear fruit and the White House announced that President Nixon would visit China. This relaxed fears among other countries that there would be American reprisals for supporting Beijing's bid to join the UN and tipped the vote for the PRC's entry at the expense of the ROC. American disapproval was far less of a concern for New Zealand the possibility of the ROC's expulsion from the UN. Regardless, Wellington knew the tide would eventually turn in Beijing's favour. 
In the UN New Zealand could work with its allies and help lobby to keep the ROC inside the UN, but ultimately it would have to accept the vote of the General Assembly on the issue of Chinese representation. However, direct diplomatic relations were made by governments individually. Since 1949 successive New Zealand governments had refused to recognise the PRC for a number of reasons that weren't necessarily related to strategic threat: lack of direct economic interests in China, opposition to communism, loyalty to the ROC, little practical advantage in diplomatic relations, American and Australian non-recognition, and the domestic unpopularity of the PRC. ${ }^{577}$ Recognition did not equate to support for a state or government, but it did allow for greater communication. The UK and a small number of other (mostly Scandinavian) European countries recognised the PRC in the early 1950s, but between 1955 and 1970 the only Western country to recognise the Beijing Government was France in January 1964. However, once the PRC entered the UN the trickle of recognition became a flood with a large number of Western and non-aligned countries recognising the PRC. While the legal details and case law relating to diplomatic recognition is complex, ${ }^{578}$ this chapter will detail how recognition was dealt with in New Zealand, which considered the issue to be primarily a political decision.

This political decision would not be made during the Second National Government. Ultimately recognition would come with the election of a Labour government. Holyoake became deeply interested in China policy towards the end of his premiership. He was aware of the changes occurring in China's foreign policies and the direction of global opinion. However, like previous prime ministers, he was reluctant to give up recognition of the Republic of China. Holyoake's attempts at recognising both Beijing and Taipei would be thwarted by the unwillingness of the PRC or ROC to accept such a proposal. He acknowledged that a 'two China' policy was not going to be acceptable on either side of the Taiwan Strait but thought it was the best compromise possible. Yet it would take a change of government in New Zealand before official relations between Wellington and Beijing could be established.

The failure of containment meant China policy moved from an area dominated by defence concerns to diplomatic ones. This amounted to a power shift from the defence establishment

577 Daiman Smith, 'Official Attitudes Towards China Between 1945 and 1957: The Development of the NonRecognition Policy', MA Thesis, Massey University, 1997, pp. 102-107

578 Recognition in international law has a significant body of literature. For the basis of recognition in British law see: Hersh Lauterpacht, Recognition in International Law, Cambridge University Press, Cambridge, 1947 
to the foreign policy establishment on New Zealand's China policy. The defence establishment became the losers from these events. The declines in SEATO's relevance, the perceived threat from China, the Government's financial position, and public support for defence due to the Vietnam War all influenced the Government in making considerable cuts in defence spending. The large upgrades of the 1960s were not to be repeated in the $1970 \mathrm{~s}$, even if New Zealand was to continue to station some forces in South East Asia. These cuts put considerable strain on civil-military relations; the chiefs opposed them in the strongest terms possible short of rebellion. ${ }^{579}$

The armed forces were facing not only a loss of funding, but also a loss of direction. Without a central threat or a major permanent international coalition to be part of, New Zealand's defence lost its road map. The continued forward deployment of New Zealand forces to Singapore had its advantages, but it was no longer under the pretext of containing China. The introduction of the Five Power Defence Arrangements in 1971 was not designed to contain China in the way that SEATO or ANZAM had been. With the election of the Kirk Government new defence goals had to be implemented which required the military to find a new role for itself in a new environment where the Cold War seemed much further away from New Zealand's shores and security assessments.

This chapter is divided into three sections to highlight the parallel but interconnected problems faced by New Zealand's diplomatic and military establishments during this period. The first section follows how the increase in Chinese diplomatic activity and Nixon's election influenced New Zealand's thinking in both defence and diplomatic areas. The next section follows how the defence establishment dealt with the loss of China as a threat, British and American withdrawal, and significant budget pressures. The final section looks at how Beijing's UN admission, Wellington's recognition of the PRC, and defence and foreign policy issues developed under Norman Kirk's leadership.

\subsection{New Zealand AND the New Chinese Diplomacy to 1970}

\subsubsection{China and the UN}

Despite the Republic of China's defeat on the mainland in the Chinese Civil War, it continued to represent China at the United Nations. The PRC's replacement of the ROC at

579 Chief of Defence Staff, Thornton, to MinDef, c. January 1971, MoD 1/1/2 Vol. 8, New Zealand Defence Policy - Review of Defence Policy, 1970-71 
the United Nations in October 1971 was the watershed moment for China's growing influence in the world. The effort to keep the PRC from being admitted to the UN was led by Western nations which were able to dominate the General Assembly in the early years of the institution. As an ally of the 'big three' during the Second World War the ROC was an original member of the United Nations and also given a permanent seat on the UN Security Council. ${ }^{580}$ The creation of the PRC in 1949 did not immediately lead to a change in the UN as the ROC still existed and Communist China had little support in the international body from outside the Soviet bloc. However, votes in the General Assembly slowly turned in Beijing's favour as decolonisation expanded the number of sovereign nations. Newly independent third-world nations tended to join the Non-Aligned Movement and had little reason to oppose the PRC's admission. As Chinese foreign policy emerged from the Cultural Revolution it was able to harness the support of these new states as well as improving relations with Europe to win a vote to expel the ROC in favour of the PRC.

New Zealand was a committed member of the coalition to keep the ROC in the UN and the PRC out. However, there was a feeling of inevitability amongst New Zealand officials that Beijing would sooner or later gain the votes to enter the international body; little Taiwan could not claim to represent the most populous country in the world forever. Initially the Soviet Union led moves to bring Communist China into the UN at the expense of Taiwan. From 1951 to 1960 the US-led opposition used a procedural motion - known as the 'moratorium proposal' - to postpone any discussion of the Soviet proposal for Beijing's admission until the following year. The Labour Government of Walter Nash was more reluctant to oppose the PRC's admission and abstained from the moratorium proposal between 1958 and 1960, but with the return of Holyoake to government New Zealand resumed voting against Beijing's entry. ${ }^{581}$

By 1960 support for China's admission had grown and the moratorium proposal won by 41 for, 34 against, and 22 abstaining. ${ }^{582}$ This caused the Americans to look for a new method for blocking China's entry. From 1961 the US championed making the issue of Chinese representation an 'Important Question' (IQ) under Article 18 (ii) of the UN Charter. This meant that voting on the issue of representation would be subject to a two-thirds majority. At

580 Stephen C. Schlesinger, Act of Creation: The Founding of the United Nations, Westview Press, Cambridge, MA, 2003

581 Roy Gordon Shuker, 'New Zealand Policy and Attitudes Toward Communist China', MA Thesis, VUW, January 1971, p. 150

582 John Scott, 'Recognising China' in Malcolm McKinnon (ed.), New Zealand in World Affairs Volume II 1957-1972, NZIIA, Wellington, 1991, p. 230 
the time, opponents of PRC admission were still in the majority, but the IQ tactic allowed countries to support the American block of the PRC without explicitly voting against the Soviet proposal. ${ }^{583}$ The US continued to use the IQ tactic for another decade, but support for Beijing continued to build. After the Sino-Soviet split Albania became Beijing's biggest supporter in the United Nations and from 1963 it took over Beijing's cause in the UN. Both Beijing and Taipei actively courted the new African states in the UN and after the heat of the Cultural Revolution began to dissipate they became more vigorous in their lobbying.

Washington had opposed Beijing's admission to the UN ever since the creation of the PRC. Dwight Eisenhower had resolutely opposed China's UN membership and thought, should it occur, that the US Congress would demand the US withdraw from the international body. ${ }^{584}$ John F. Kennedy was reluctant to change US China policy as polling showed the US was still strongly opposed to Communist China joining the UN, but there was some support for change amongst members of his administration. Kennedy's UN Ambassador Adlai Stevenson ${ }^{585}$ and Under-Secretary of State Chester Bowles ${ }^{586}$ had both written articles in 1960 advocating a 'two Chinas' solution in the UN. In January 1961, fearing the moratorium vote would be lost, Kennedy told the British Ambassador in Washington Harold Caccia that the US could accept Beijing's admission if Taiwan was provided for: effectively a two Chinas solution. This brought the White House swift condemnation from Congress, Taipei, and even Beijing. ${ }^{587}$ Communist China's polemical response angered Kennedy into refraining from any further attempt at softening US China policy. ${ }^{588}$ The Johnson Administration would again look at a 'two China' solution in 1966 but by this point the Cultural Revolution had begun and the Americans continued with the IQ manoeuvre. ${ }^{589}$

\footnotetext{
583 New Zealand voted consistently for the Albanian resolution to be made an IQ and consistently against the Albanian resolution.

584 Victor S. Kaufman, "Chirep': The Anglo-American Dispute over Chinese Representation in the United Nations, 1950-71', The English Historical Review, Vol. 115, No. 461, April 2000, p. 361

585 Adlai Stevenson, 'Putting First Things First', Foreign Affairs, xxxviii, January 1960, p. 203

586 Chester Bowles, 'The "China Problem" Reconsidered', Foreign Affairs, xxxviii, April 1960, p. 476-486

587 Rosemary Foot, 'US Hegemony and International Legitimacy: The Chinese Representation Issue at the United Nations' in The Practice of Power: US Relations with China since 1949, Oxford Scholarship Online, 1997, p. 38

588 Kaufman, 2000, p. 367

589 Kaufman, 2000, p. 373
} 


\subsubsection{Holyoake's China Diplomacy}

Holyoake became deeply interested in China policy during the last years of his premiership. ${ }^{590}$ The prime minister became more active in China policy as the possibility of diplomatic engagement with Beijing grew. He lobbied the public and his caucus for a 'Two China' solution to the problem of recognising the PRC. ${ }^{591}$ Holyoake was not prepared to admit the PRC to the United Nations or provide it with diplomatic recognition at the expense of the ROC. Like Peter Fraser who in 1949 would not turn his back on an ally from the Second World War, Holyoake would not abandon what he saw as a friendly small state being pressured by a larger one. ${ }^{592}$ Two decades after the creation of the PRC the international situation had changed and Holyoake was much more enthusiastic about recognition of Beijing than Fraser had been, but the status of Taiwan remained a stumbling block.

Holyoake had long been willing to accept the PRC joining the UN provided the ROC was not expelled. In 1962 he told the ROC that New Zealand did not 'rule out the possibility of a two Chinas or one China and one Taiwan solution'. ${ }^{593}$ That is to say Holyoake was open to the idea of accepting both states as rulers of 'China' or accepting the basic reality that China was divided with the ROC controlling Taiwan and a few other offshore islands. As with Kennedy's proposal, neither of these options were acceptable to Beijing or Taipei who considered China indivisible and themselves to be the only legitimate government of China. In 1966 Frank Corner, then leader of the NZ delegation to the UN, said:

The New Zealand Government is not prepared to support the seating of Communist China in the United Nations on a basis that would acknowledge the right claimed by Communist China to attempt to seize Taiwan by force. It would nonetheless be prepared to give serious consideration to any proposal aimed at seating Communist China in the United Nations provided this was not to be brought about at the expense of

\footnotetext{
590 Holyoake was replaced as Prime Minister by Jack Marshall in February 1972, but Holyoake stayed on as Minister of Foreign Affairs until National's defeat in the election of November that year.

591 The first proponent of a two-China policy in the New Zealand Government was Clifton Webb who was Minister of External Affairs from 1951 to 1954. He was a strong advocate of recognition and admission of Beijing without breaking ties with Taiwan, but his views were not supported by officials or the rest of Cabinet. See Barry Gustafson, Kiwi Keith: A Biography of Keith Holyoake, Auckland University Press, Auckland, 2007, p. 268; and Daiman Smith, Official Attitudes Toward China Between 1945 and 1957: The Development of the Non-Recognition Policy, MA Thesis, Massey University, 1997

592 Daiman Smith, 1997, pp. 40-41

593 Scott, 1991, p. 231
} 
the Republic of China or in a manner that would jeopardise the right of the people of Taiwan to a voice as to their future. ${ }^{594}$

Statements to this effect were made by Holyoake in the introductions of the 1967 and 1968 annual reports of the Department of External Affairs. ${ }^{595}$ Despite the dramatic changes in New Zealand's assessment of China between 1965 and 1968, its official positions on recognition of the PRC and its admission to the UN did not change much in the 1960s. Nevertheless, the changes in New Zealand's view of China allowed for changes in policy once the most chaotic period of the Cultural Revolution was over and Mao moved to improve relations with the outside world, but Holyoake's commitment to the ROC would remain problematic.

\subsubsection{Assessing and Managing the Change in Chinese Foreign Policy}

Keeping on top of the changes in Chinese foreign policy would be vital given the rapid pace of change. Holyoake and his officials were looking for signs of Beijing opening to the outside world. The New Zealand Ministry of Foreign Affairs ${ }^{596}$ believed it was the moderates led by Zhou that were leading the change toward better foreign relations and not the supporters of the Cultural Revolution. It felt that the moderates would become more powerful as time went on. The $9^{\text {th }}$ Party Congress in April 1969 was taken by officials as a signal that China would be returning to more stable policies. In a telegram to the Tokyo Embassy, the Ministry outlined its view that the $9^{\text {th }}$ Party Congress:

...represents the ending of the worst period of confusion brought about by the Cultural Revolution and that a new period of reconstruction is about to be embarked upon. We would expect, eventually, that this will lead to more pragmatic and flexible policies in the external field. We note that while radical elements have retained a key position in the communist hierarchy they are balanced, to some degree, by [Zhou] En Lai (and the professional administration he represents) and the military (whom we would tend to regard as more conservative). We would expect the views of these less extreme groups to grow in influence as Mao's control over China slackens... obviously Communist China's objectives have not RPT not changed, but we may, over the next few years, need to show greater imagination and skill ourselves in dealing with more determined and

\footnotetext{
594 Frank Corner, 28 November 1966, quoted in memo for all ministers, 6 August 1971, ABHS W4627 950

Box 4080, 264/4/14 33A, China: Political Affairs - Recognition of Communist China, 1971

595 'Report of the Department of External Affairs', AJHR, A.1, Vol. 1, 1967 and 1968

596 The Department of External Affairs was renamed the Ministry of Foreign Affairs in 1969.
} 
effective endeavours by Communist China to extend its influence throughout Asia. ${ }^{597}$

The response from the Japanese Government was less optimistic. The Japanese Minister of Foreign Affairs told the New Zealand embassy in Tokyo that it considered the PRC to have become a virtual military dictatorship with the leadership still favouring extremism and only lightly moderated by the conservative bureaucracy. ${ }^{598}$ A public statement of Holyoake's opinion came in May with a report of the Department of External Affairs tabled in the House of Representatives. The report used extremely guarded language to note that China, while still hostile, was making tentative changes to its relationship with the United States, but not with the Soviet Union. ${ }^{599}$ The Prime Minister was well aware of movement in China's position and shifts in the attitude of other states to Beijing. The need for a change in China policy by the wider region was noted by Holyoake at the SEATO Council meeting in June. He found similar attitudes amongst the other SEATO members. Officials from Foreign Affairs noted the importance of shifting attitudes to China.

Mr Holyoake opened this topic by saying that now that Communist China appeared to be over the worst of its internal difficulties there might be new developments in Chinese external policies. The Prime Minister made the point that while Chinese objectives were scarcely likely to change the methods of pursuing them might and that the allies had to be ready to deal with them. This led the Thai Foreign Minister to develop the theme he has put forward over recent months of the need for Asian leaders to try to get a dialogue going with the Communist Chinese leaders. ${ }^{600}$

Holyoake and his SEATO peers were looking at the problem of Chinese power differently. While SEATO's leaders were not about to lose their distrust of Beijing and its influence, they had begun to see China's politics as evolving and bringing it more in line with standard diplomatic practice. For the Ministry of Foreign Affairs these were not throwaway comments. The ministry saw these comments as reflection of a wider change in ideas driven by American fatigue in South East Asia as much as change in Beijing.

The exchanges were interesting not so much for what was actually said as for the indication that was given of a new approach to Asian politics. The

\footnotetext{
597 SecFA to NZ Embassy Tokyo, 9 May 1969, ABHS W4627 Box 4072 264/4/1 Vol. 22, China: Political Affairs - General 1968-69

598 Statement by Mr K. Aichi, ASPAC: Standing Committee, 14 May 1969, ABHS W4627 Box 4072 264/4/1 Vol. 22, China: Political Affairs - General 1968-69

599 'China's calm not sign of friendship', Information and Press Section, Publicity Division, 15 May 1969, ABHS W4627 Box 4072 264/4/1 Vol. 22, China: Political Affairs - General 1968-69

600 SEATO Council Report by Department of External Affairs, 30 June 1969, ABHS W4627 Box 4072 264/4/1 Vol. 22, China: Political Affairs - General 1968-69
} 
prolonged discussion over the future of American policies in the area has obviously had its impact. There appears to be a growing feeling that if the Americans are not going to be as deeply involved in the Asian mainland as they have been up to now it makes sense for Asian countries to try to get a better relationship with Communist China. This by no means implies recognising the Peking Government and establishing diplomatic relations with that regime. It does mean, however, that there is likely to be a growing disposition on the part of Asians to talk a little less harshly about the Chinese - and it makes sense, if you are not quite so certain about the extent you can rely upon the Americans, to avoid as far as possible antagonising the major Asian communist power. In terms of immediate practical politics this does not mean too much, but in the long term it could be a tendency of considerable importance. ${ }^{601}$

With the kind of containment practised in the 1960s now improbable due to declining American support, the other SEATO states were looking to slowly shift to a less hostile approach to Beijing. There was not going to be a sudden love affair with the People's Republic but public antagonism of China was no longer considered wise by those who had tried to contain it. In fact, in 1969 the ministry was underestimating the speed at which attitudes towards Beijing would change in Wellington and other capitals over the next few years.

Beijing's return to normal diplomatic practice did not take long to start producing benefits. The tide in the United Nations began to turn in China's favour in 1969 and Holyoake urged it to find a solution to the China question. On 19 September of that year he told the UN General Assembly that:

The United Nations is increasingly faced with the need to come to terms with a situation where a quarter of the world's population remains unrepresented in it. The effectiveness of our organisation is impaired by a gap of this magnitude. ${ }^{602}$

Simultaneous to China's re-emergence on the world stage was a serious decline in its relations with the Soviet Union. By the end of 1969 Sino-Soviet relations had deteriorated so badly that it looked to be the problem dominating Chinese foreign policy. This dangerous decline in relations between the two communist powers, and China's newfound diplomacy provided an opportunity for the new Nixon administration to reshape its relationship with China, but it would still take some time before it was clear how this could happen.

${ }^{601}$ SEATO Council Report by Department of External Affairs, 30 June 1969, ABHS W4627 Box 4072 264/4/1 Vol. 22, China: Political Affairs - General 1968-69

${ }^{602}$ Keith Holyoake, Speech to UN General Assembly, 19 September 1969, ABHS W4627 950 Box 4080, 264/4/14 33A, China: Political Affairs - Recognition of Communist China, 1971 


\subsubsection{The Nixon Administration Emerges}

In many ways Holyoake's policies were more flexible than Washington's which had to move much further in its China policies to establish relations, even though Washington had signalled its desire for change early in the Nixon Administration. Well before his election (and during the turbulent phase of the Cultural Revolution) Nixon wrote of the need to change the dynamic of the Cold War and bring China into the community of nations even if it were to remain hostile to its neighbours.

Taking the long view, we simply cannot afford to leave China forever outside the family of nations, there to nurture its fantasies, cherish its hates and threaten its neighbors. There is no place on this small planet for a billion of its potentially most able people to live in angry isolation. ${ }^{603}$

However, when Nixon was elected New Zealand officials were still unclear how much change in Sino-American relations was possible as it was not known how far either the US or China were willing move towards rapprochement. In 1969 US Secretary of State William P. Rogers signalled that the US was prepared to renew the Warsaw Talks (the only significant bilateral forum for the PRC and the US between 1955 and $1970^{604}$ ) and at the same time the US relaxed some travel and trade restrictions with Communist China. ${ }^{605}$ Rogers told Holyoake at an ANZUS council meeting in August 1969 that he found the question of China's future role fascinating and that he'd detected hints that Beijing was interested in coming to an accommodation with the US but was unsure how it could be accomplished. ${ }^{606}$ The New Zealand Embassy in Washington had already noticed press reports of consultation by the US National Security Council with other government agencies on how to improve relations with Beijing. ${ }^{607}$

The introduction of the Nixon (or Guam) doctrine raised significant concerns for America's Asian allies. New Zealand assessments in the 1960s argued that the removal of American forces from the South East Asian mainland would leave little to deter China, even if US

\footnotetext{
603 Richard M. Nixon. ‘Asia After Viet Nam’, Foreign Affairs, October 1967, https://www.foreignaffairs.com/articles/asia/1967-10-01/asia-after-viet-nam

604 Between 1955 and 1970 there were 136 meetings in Warsaw and Geneva between Chinese and American officials. See: Yafeng Xia, Negotiating with the Enemy: U.S.-China Talks During the Cold War, 1949-1972 Indiana University Press, Bloomington, September 2006, Chapters 4 \&5

605 William P. Rogers, Speech to the National Press Club, Canberra, 8 August 1969, ABHS W5422 950 Box 34, 111/3/3/15 Vol. 8, International Security - Pacific Pact - ANZUS Council Meetings, ANZ, 1968-70

606 ANZUS Council Meeting, 8 August 1969, Department of External Affairs Notes, ABHS W5422 950 Box 34, 111/3/3/15 Vol. 8, International Security - Pacific Pact - ANZUS Council Meetings, ANZ, 1968-70

607 NZ Embassy Washington to SecFA, 2 April 1969, ABHS W4627 Box 4072 264/4/1 Vol. 22, China: Political Affairs - General 1968-69
} 
forces remained in offshore bases in the Western Pacific. However, by the late 1960s New Zealand officials accepted that such a withdrawal was inevitable. ${ }^{608}$ With the confirmation that Washington expected its Asian allies to take greater responsibility for their own defence, New Zealand wanted to know exactly where the new limits would be. Officials wanted to ask their American counterparts at the 1970 ANZUS Council meeting if Washington was willing to accept South East Asia coming under the influence of China or the Soviet Union and if the US would provide air support to South East Asia to help prevent this outcome even if ground troops were no longer likely. ${ }^{609}$ Laking wanted to avoid any discussion of the Sino-Soviet split in the official communiqué of the meeting and wanted all three governments to express their belief in the importance of China and the need for dialogue and better relations with the PRC. ${ }^{610}$ The final communiqué was reasonably blunt in its language, calling for greater engagement with China while also expressing concern about China's continued support for revolutionary warfare. ${ }^{611}$

In 1969 Washington began to make stronger statements on the Sino-Soviet Split. With SinoSoviet relations deteriorating badly, Nixon was in an increasingly better position to take advantage of the situation. The US had moved a long way from President Kennedy's 1963 statement that 'a dispute over how best to bury the free world is no grounds for Western rejoicing'. ${ }^{612}$ In September 1969 Under-Secretary of State Elliot Richardson said in a speech that while the ideological differences between the biggest communist powers was no business of the United States, a major military conflict between China and the Soviet Union would have an impact on America's vital interests. ${ }^{613}$ The split was no longer seen by Washington as a philosophical dispute, it was now a serious threat to international peace and security. More privately - and unknown to New Zealand's policymakers - during the previous month Nixon had made the determination to his National Security Council that the Soviet Union was the more dangerous adversary and American interests would be harmed if

\footnotetext{
608 See: Chapter 3.3.1

609 SecFA to NZ Embassy Washington, 10 September 1970, ABHS W5422 950 Box 34, 111/3/3/15 Vol. 8, International Security - Pacific Pact - ANZUS Council Meetings, ANZ, 1968-70

610 SecFA to NZ Embassy Washington, 18 September 1970, ABHS W5422 950 Box 34, 111/3/3/15 Vol. 8, International Security - Pacific Pact - ANZUS Council Meetings, ANZ, 1968-70

611 NZ Embassy Washington to SecFA, 21 September 1970, ABHS W5422 950 Box 34, 111/3/3/15 Vol. 8, International Security - Pacific Pact - ANZUS Council Meetings, ANZ, 1968-70

612 John F. Kennedy, 'State of the Union', Speech, Washington, 1963, http://www.presidency.ucsb.edu/ws/?pid=9138

613 Elliot L. Richardson, 'The Foreign Policy of the Nixon Administration', Speech, American Political Science Association, 5 September 1969, 'Department of State Bulletin 61', No. 1567, p. 260, http://babel.hathitrust.org/cgi/pt?id=uc1.31158006191430; view=1up;seq=312
} 
China was to be crushed by the Soviets. ${ }^{614}$ By taking the seriousness of the split more seriously the US was putting itself into a position where it was easier to make a change towards engagement with Beijing.

While the extent of Nixon's ambitions for Sino-American relations were not completely clear to New Zealand officials, the Americans continued to share their views on China with them. A US State Department report from early 1970, given to the New Zealand Commission in Hong Kong, took the view that the revolution continued to dissipate due to the order provided by the PLA and that China's fears of an American attack had been largely displaced by the growing Soviet threat. The report noted that these elements were present a year previously but the events of 1969 had changed their importance.

Viewing China as 1969 ends compared to a year ago is something like playing with a kaleidoscope: the pieces are the same but rearranged, the focus has shifted. ${ }^{615}$

At the turn of the 1970s it was slowly becoming clear to many New Zealand officials that China was heading for some kind of rapprochement with not only the West but also the noncommunist nations of South East Asia. The extent and the ramifications of this change were not yet clear. Political conditions in China may have calmed since the heady days of 1966 and 1967 but Maoist China was still wholly alien to the West and significant challenges to better relations remained. With containment looking less and less practical, the growing public opposition to the Vietnam War, changes in China's foreign policy, and economic challenges for the New Zealand government, it became clear that defence policy would need to change.

\subsection{Defence Policy Responds to Change: $1970-1972$}

New Zealand's defence establishment faced several significant challenges from 1969. These challenges stemmed from the decline in the perception of threat from China, the impending withdrawal of British and American forces from the mainland, the related breakdown of alliance structures for the region, and a tightening of New Zealand's fiscal situation. While SEATO's leaders recognised they needed to change their approach to China, defence officials thought the relevance of the organisation had declined even further. In March 1969

\footnotetext{
${ }^{614}$ Henry Kissinger, The White House Years, Little, Brown \& Co, Boston, 1979, p. 182

615 'Review of Developments in Communist China', US Consulate General Hong Kong, in Commission to SecEx, 17 February 1970, ABHS W4628 6944 Box 8, HKG 82/1/1 Vol. 5, China - Political Affairs General 1970-73
} 
the Defence Planning Committee decided that British withdrawal had 'invalidated' New Zealand's SEATO operational concepts. This meant new concepts would need to be established with Australia if New Zealand was to deploy forces according to SEATO plans. ${ }^{616}$ However, by the end of 1969 faith in SEATO had dropped to the point where the Defence Planning Committee recommended that the readiness of New Zealand's forces in South East Asia be based on the 'assessed probability of hostilities rather than to the requirements of any particular SEATO contingency plan'. ${ }^{617}$ Previously readiness had been tied to SEATO Plan 4 but given the financial constraints and the 'improbability of major hostilities' this requirement seemed unrealistic. ${ }^{618}$

\subsubsection{Quanta and Commitments for the 1970s}

Political and economic forces continued to move faster than the ability of the Ministry of Defence to produce a defence review. The preparation for the 1970 Defence Review (which would not be completed until 1972) was set against major financial pressure from the Holyoake Government. These pressures had existed during the earlier reviews, but by the end of the 1960s the Government was prepared to make significant cuts to military capabilities rather than just delay upgrades. New Zealand was not going to withdraw from its military commitments to Asia, but the frameworks for New Zealand's commitment were also experiencing significant change.

In January 1970 Laking wrote that while New Zealand could not withdraw from any of its broader security commitments (such as SEATO, ANZUS, ANZAM, and Commonwealth agreements) without significant harm to the willingness of the US to defend the region, it could reduce the amount of effort provided to those commitments. Laking realised these agreements could change over time, perhaps with greater involvement of the Asian states, but New Zealand could not unilaterally exit from its commitments without damaging its interests. ${ }^{619}$ However, Laking also considered the necessary level of military commitment to be undefined:

\footnotetext{
616 'Operational Concepts for New Zealand Forces', Annex A to DPS(69)21, 21 March 1969, MoD, 1/1/6 Vol. 2, NZ Defence Commitments, October 1968-1972

617 'Operational Readiness', Annex A to DPS(69)80, 7 November 1969, MoD 1/1/2 Vol. 6, New Zealand Defence Policy - Review of Defence Policy, 1969

618 'Operational Readiness', Annex A to DPS(69)80, 7 November 1969, MoD 1/1/2 Vol. 6, New Zealand Defence Policy - Review of Defence Policy, 1969

${ }^{619}$ SecEx to SecDef, 13 January 1970, MoD 1/1/2 Vol. 7, New Zealand Defence Policy - Review of Defence Policy, 1970
} 
Acceptance of these obligations does not lead automatically to the acceptance of a specific programme for the size and shape of our forces. It is not, for instance, realistic to consider whether under our Manila Treaty obligations we are obliged to have a capability to contribute a division, or a brigade group or a battalion group. Our obligations are, of necessity, expressed in general terms and need to be weighed in the light of the actual situation, including the actions of our allies, and of our real capabilities. What does follow inescapably from the obligations we have accepted is the need to be able to make a reasonable contribution in the areas of primary strategic interest, South-east Asia and the South Pacific. Judgement will be required as to what constitutes a reasonable contribution. ${ }^{620}$ (original emphasis)

This was a very different argument to those made during the mid-1960s when SEATO declarations were treated as a framework for determining necessary capabilities. South East Asia and the South Pacific were still the areas of primary strategic interest but the attitude towards them had changed. With the threat from China no longer dominating New Zealand thinking, Laking could argue the minimum force New Zealand needed to maintain in Asia was not prescribed by its formal defence agreements but by the attitude of its allies. Without a significant threat from China or a significant containment force on the Asian mainland, New Zealand had the flexibility to reduce its commitments in Asia up to the point where the US and others considered New Zealand to no longer be an active participant in the region's security. Laking thought this minimum still necessitated New Zealand forces stationed on the ground in South East Asia for use in an emergency and that these forces needed the ability to be expanded quickly in the event of a more significant conflict. The forward deployed force needed to be of a scale that allowed for the development of useful expertise and, moreover, it needed to be big enough to permit separate political and military management by New Zealand. While suggesting that there was potential flexibility in New Zealand's Asian deployments, Laking was still concerned that a cut in defence spending would send a dangerous signal to New Zealand's allies and would in effect damage their commitment to New Zealand's interests in the region. ${ }^{621}$

While Laking was suggesting that it could be possible to decrease the quantum of force deployed in Asia, the defence establishment was examining the expected roles for New Zealand forces given the perceived drop in risk from China and the decline in great power support. The 1970 'Size and Shape' report stated that the missions of the armed forces were

${ }^{620}$ SecEx to SecDef, 13 January 1970, MoD 1/1/2 Vol. 7, New Zealand Defence Policy - Review of Defence Policy, 1970

${ }^{621}$ SecEx to SecDef, 13 January 1970, MoD 1/1/2 Vol. 7, New Zealand Defence Policy - Review of Defence Policy, 1970 
firstly to maintain capabilities which could be deployed to assist Malaysia and Singapore against limited external attack or externally-promoted insurgency, or for similar emergencies in South East Asia; secondly, to maintain the ability to contribute to larger forces in 'the event of more extensive hostilities' including the defence of the air and sea approaches to South East Asia; and thirdly, to maintain the expertise of the armed forces. ${ }^{622}$ The threat of major hostilities was still present but it was not feared to the same extent it had been during the creation of the 1966 review. China had the potential to interfere through 'externallypromoted insurgency' but even this threat was not taken with the same degree of seriousness that it had been previously.

While the pessimism about the future of South East Asia that featured heavily during the defence review process in the 1960s had disappeared by the early 1970s, there was more uncertainty than optimism. Nevertheless, new possibilities were explored. For the first time in the defence review process it was acknowledged that South East Asia might offer a useful export market provided it could remain stable politically. More effort was made in the draft 1970 review to link trade with security issues. The review pointed to statements made by Holyoake to President Nixon that without trade New Zealand would have been unable to take part in collective defence, and noted that the Americans correspondingly thought trade could be made possible by collective defence efforts. ${ }^{623}$

\subsubsection{Joint Intelligence Committee Assessment - October 1970}

The thinking of the defence chiefs had moved away from a strong focus on China by the time of the 1970 review process. Their requests for information from the Joint Intelligence Committee were no longer about China as they had been during the review processes of the mid-to-late 1960s. In 1970 they had begun to relate to more distant concerns like Soviet naval presence in the Indian Ocean. ${ }^{624}$ However, the JIC itself did not yet predict rapprochement between China and the US. Its October 1970 assessment for the period of 1970-1975 foresaw three-way hostility continuing between Washington, Beijing, and Moscow.

622 'Size and Shape of the Armed Forces', Memo for Cabinet Defence Committee, 26 January 1970, MoD 1/1/2 Vol. 7, New Zealand Defence Policy - Review of Defence Policy, 1970

623 'Size and Shape of the Armed Forces', Memo for Cabinet Defence Committee, 26 January 1970, MoD 1/1/2 Vol. 7, New Zealand Defence Policy - Review of Defence Policy, 1970

624 'The Strategic Outlook for the Pacific Area: 1970-75 and Beyond', October 1970, JIC(NZ)(70)17, MoD 1/1/1, New Zealand Defence Policy - General, 1968-1972 
Communist China, although preoccupied with internal problems and with the threat from the Soviet Union, will endeavour to expand its influence, making greater use of its diplomatic opportunities. It may make some limited response to moves by the Soviet Union and the United States to improve relations or to limit the risks in particular situations, but will not abandon its basic hostility to both. Peking will continue to support insurgency, particularly among the hill peoples of Laos, Thailand, Burma and, though with less success, Maoist movements in other parts of South East Asia. ${ }^{625}$

Despite taking the view that three-way tensions would continue, the JIC did think that the deaths of Mao and Chiang Kai-Shek could lead to an accommodation between Beijing and Taipei. ${ }^{626}$ With or without a cross-strait accommodation the JIC thought that all the great powers would seek to avoid direct involvement in an Asian conflict, and a Vietnam-style war was unlikely. It believed the most likely source of conflict in Asia was on the Korean Peninsula, but in that case the Soviet Union and US would attempt to localise the conflict and try to avoid becoming involved themselves. ${ }^{627}$ The greatest threat to New Zealand becoming involved in a military clash was viewed by the JIC to come from 'communist terrorist operations' in northern Malaysia, but without any suggestion such operations risked escalation with China. ${ }^{628}$ The chiefs endorsed the JIC's assessment on 23 October $1970 .{ }^{629}$ The chiefs own report of that year added that the biggest threat to regional security was tension between South East Asian states and 'externally-promoted insurgency'.630 Collectively, the chiefs and the JIC still saw China a threat through its promotion of revolutionary movements, but not as a direct military threat to South East Asia.

\subsubsection{The Chiefs Debate the Value of Forward Defence}

The missions outlined in the draft 1970 defence review were opposed by the Chief of Air Staff, Air Vice Marshal William Stratton, in a written dissent from the views of the other chiefs. He felt it was inadvisable for New Zealand to become involved in counter insurgency

\footnotetext{
625 'The Strategic Outlook for the Pacific Area: 1970-75 and Beyond', October 1970, JIC(NZ)(70)17, MoD 1/1/1, New Zealand Defence Policy - General, 1968-1972

626 'The Strategic Outlook for the Pacific Area: 1970-75 and Beyond', October 1970, JIC(NZ)(70)17, MoD 1/1/1, New Zealand Defence Policy - General, 1968-1972

627 'The Strategic Outlook for the Pacific Area: 1970-75 and Beyond', October 1970, JIC(NZ)(70)17, MoD 1/1/1, New Zealand Defence Policy - General, 1968-1972

628 'The Strategic Outlook for the Pacific Area: 1970-75 and Beyond', October 1970, JIC(NZ)(70)17, MoD 1/1/1, New Zealand Defence Policy - General, 1968-1972

${ }^{629}$ Chiefs of Staff Committee Meeting, COS/M(70)32, MoD 1/1/1, New Zealand Defence Policy - General, 1968-1972

630 'Size and Shape of New Zealand Forces', COS(70)27, 29 October 1970, MoD 1/1/2 Vol. 7, New Zealand Defence Policy - Review of Defence Policy, 1970
} 
on the Malaysia/Thailand border as it would be impossible to determine whether insurgent action was externally supported. He felt any New Zealand support for military action that could be construed as supporting Malaysian subjugation of ethnic Chinese would exacerbate tensions between Malaysia and Singapore, and would threaten Singapore's interest in hosting New Zealand forces. Stratton felt New Zealand should avoid any specific priorities and focus on maintaining a general set of expertise and capabilities to the level at which the Government could afford. ${ }^{631}$ The Chief of Naval Staff, Rear Admiral Lawrence Carr, wrote a similar memo arguing that the 'Size and Shape' section of the review had failed to adequately assess a range of issues including the Nixon doctrine, the extent of the British commitment in Asia, the position of the Australian Labor Party, and the JIC's view that all ANZUK forces were likely to withdraw from Asia by the end of the 1970s. Carr believed these factors required greater flexibility in defence policy and some preparations should be made for future withdrawal from South East Asia. ${ }^{632}$

The Secretary of Defence wrote to the members of the Defence Council to rebut the statements of the CAS and CNS. The Secretary noted that the Stratton had a point that the shape of New Zealand's forces did not exactly match the threat profile, but New Zealand's forces were large enough for the roles provided to South East Asia to have political pay-offs even if the capabilities New Zealand provided did not exactly match the military need.

It can hardly be contested that the political advantages to be gained justify a presence in South East Asia in some form, even if the resultant deployment is not always what might be regarded as sound militarily. Roles, missions and military effort in peacetime in a small country like New Zealand must in practice reinforce the political objectives of foreign policy, even if by doing so some combat readiness is lost. This is a legitimate risk to take in a period of negligible threat if it ensures national security is fully protected by collective defence arrangements at times of severe threat. ${ }^{633}$

The Secretary's language of 'peacetime' and 'negligible threat' is very different from earlier reviews which highlighted the risk from China and Chinese-supported insurgency. The Secretary did not list the specific political benefits he was alluding to other than the maintenance of the American security guarantee. He was also concerned that if defence

631 'CAS' Dissenting View', DO(70)75, 5 November 1970, MoD 1/1/2 Vol. 7, New Zealand Defence Policy Review of Defence Policy, 1970

632 'Note by Chief of Naval Staff', COS/M(70)33, 11 November 1970, MoD 1/1/2 Vol. 7, New Zealand Defence Policy - Review of Defence Policy, 1970

633 'Item 5, Defence Council Agenda', 11 November 1970, MoD 1/1/2 Vol. 7, New Zealand Defence Policy Review of Defence Policy, 1970 
needs were determined by a measure of the direct threat to New Zealand then defence would be unable to argue for a significant portion of government expenditure. The defence force that resulted from such determinations would 'be of little value, either for long term political objectives of collective defence or a nucleus for self-defence'. ${ }^{634}$

The Secretary was still committed to the Forward Defence concept even if allies, the JIC, and the chiefs themselves were becoming wary of its practicality. He continued to state the importance of SEATO and the need to maintain American and British interest in South East Asia 'and in the containment of Communist China'. ${ }^{635}$ Nevertheless he felt changes such as ending the need for all three services to be stationed in Singapore at once and reducing specific declarations to SEATO could be made without damaging New Zealand's interests.

\subsubsection{Government Cuts to Defence Spending Growth}

In December 1970 Defence Minister David Thomson wrote to the Secretary of Defence warning that Cabinet was seriously considering large cuts in defence spending by removing major capabilities. ${ }^{636}$ Under consideration was keeping the defence budget to a $4 \%$ increase in real terms as opposed to the $11 \%$ necessary to maintain existing commitments. ${ }^{637}$ Such a restriction on spending would require the deferment of patrol craft purchases, discontinuance of Antarctic support missions, the reduction of Army manpower by 120 men, the shifting of national service and hydrographic research from the defence vote, and the mothballing of a frigate and two Orions. Thomson told the Secretary that he was strongly opposed to these cuts which he considered would have 'sweeping' and 'calamitous effects' on the morale and the effectiveness of the armed forces. Thomson was under considerable pressure from his cabinet colleagues and demanded that the Secretary of Defence produce a paper on the effects for Cabinet over the weekend. The chiefs agreed to a meeting of the Defence Council on the Saturday morning. ${ }^{638}$

Understandably the Defence Council was deeply concerned about the possibility of cuts to its capabilities in South East Asia. The Council believed the proposed spending levels would limit New Zealand's presence in Singapore/Malaysia to one frigate for $60 \%$ of the year, a

\footnotetext{
634 'Item 5, Defence Council Agenda', 11 November 1970, MoD 1/1/2 Vol. 7, New Zealand Defence Policy Review of Defence Policy, 1970

635 'Item 5, Defence Council Agenda', 11 November 1970, MoD 1/1/2 Vol. 7, New Zealand Defence Policy Review of Defence Policy, 1970

636 MinDef to SecDef, 18 December 1970, MoD 1/1/1, New Zealand Defence Policy - General, 1968-1972

637 MinDef to Cabinet, 21 December 1970, MoD 1/1/1, New Zealand Defence Policy - General, 1968-1972

638 'Chiefs of Staff Committee', COS/M(70)38, 18 December 1970, MoD 1/1/1, New Zealand Defence Policy

- General, 1968-1972
} 
reduced infantry battalion, approximately four aircraft, and a contribution towards logistics, headquarters, communication, and administration. ${ }^{639}$ In the view of Thornton, Chief of Defence Staff, this would 'certainly cast into doubt the continuing credibility of New Zealand's contribution to collective defence and reduced the degree of national independence of action'. ${ }^{640}$ At another meeting he said that any attempt to do away with the army's brigade group concept would make the armed services 'a scratch force, unable to play its part in the national security, with its consequential effect on relations with our major allies'. ${ }^{641}$ In his mind cuts would mean the end of the Forward Defence concept and would be, in effect, a shift to home defence. The minister explained to his Cabinet colleagues that savings would be particularly difficult given that Cabinet was not intending to make any changes to policy, and thus the forces would have to do more with less. ${ }^{642} \mathrm{He}$ warned Cabinet that the cuts would have effects:

...felt in every aspect of Service life, and they will further reduce our already limited operational capability to an extent which the Defence Council believes to be dangerous to the long-term security of the country and damaging to our relationships (in the defence field at least) with our principal Allies, both now and in the future. ${ }^{643}$

Unlike in the review processes of 1966 and 1968, the chiefs could not claim that New Zealand was experiencing major strategic pressures or needed major capital equipment upgrades. This environment was distinctly different from that of the mid-1960s during which New Zealand's military had been transformed. It had received major upgrades of significant capital equipment. This level of spending could not continue as there was no longer the necessary threat perception or political will to support it. The Government's reluctance to fund defence had overcome the pressures created by the threats perceived to South East Asia and the need for new equipment that existed in the mid-1960s. While New Zealand and Australia were being left to support Malaysia and Singapore the threats perceived by New Zealand officials were also falling. With the threat from China dissipating and direct British and American containment no longer possible, the Government felt it

\footnotetext{
639 MinDef to Cabinet, 21 December 1970, MoD 1/1/1, New Zealand Defence Policy - General, 1968-1972

640 'Chiefs of Staff Committee', COS/M(71)3Sp, 3-5 February 1971, MoD 1/1/1, New Zealand Defence Policy - General, 1968-1972

641 'Chiefs of Staff Committee', COS/M(71)Sp4, 8 February 1971, MoD 1/1/1, New Zealand Defence Policy General, 1968-1972

${ }^{642}$ MinDef to Cabinet, c. February 1971, MoD 1/1/1, New Zealand Defence Policy - General, 1968-1972

${ }^{643}$ MinDef to Cabinet, c. February 1971, MoD 1/1/1, New Zealand Defence Policy - General, 1968-1972
} 
could reduce the amount spent on defence without radically changing its publicly stated commitments.

However, regardless of their thoughts on the suitability of the overall strategic direction, the chiefs understandably did not want to endure spending cuts. Thornton used the strongest language possible while still remaining committed to the military's subordination to the elected civilian leadership.

The Chiefs of Staff do not, of course, question the fact that the allocation of national resources must be decided by Government. However, the reductions now proposed will be so far-reaching in their effects on the Armed Forces that the Chiefs of Staff wish to record the strongest possible recommendation against the imposition of these cuts; they wish to place very clearly before the Government their considered view that if these reductions have to be instituted, our operational capacity and readiness, already at the minimum acceptable level, will be reduced to such an extent that recovery could not be effected for some years. ${ }^{644}$

Savings were eventually found by returning the HMNZS Endeavour (A184) to the US Navy, ${ }^{645}$ reducing RNZAF flying hours, reducing the National Service Scheme, and eliminating the non-regular cadet forces and dental services for Territorial personnel. ${ }^{646}$ While not as extreme as those first suggested by the Government, cuts like these were representative of a power shift between the defence establishment and Foreign Affairs. As Forward Defence had become an exercise of more limited means chasing more limited ends, the need for more direct diplomatic engagement with emerging South East Asian nations and China itself increased. Anglo-American withdrawal meant South East Asian nations needed to step up their own defences and New Zealand needed to work even more closely with them requiring more diplomatic effort. Diplomatic engagement with Malaysia and Singapore had been going on since their independence but this needed to increase with the withdrawal of the great powers. However, the bigger challenge was establishing a functional relationship with China itself. This would depend on how China was perceived in the new and rapidly changing environment. The JIC was called to update its strategic outlook just six months after the last report.

\footnotetext{
${ }^{644}$ Chief of Defence Staff, Thornton, to MinDef, c. January 1971, MoD 1/1/2 Vol. 8, New Zealand Defence Policy - Review of Defence Policy, 1970-71

645 Somewhat ironically the Endeavour was then on-sold to the ROC and became the ROCS Lung Chuan.

${ }^{646}$ MinDef to Cabinet, 11 March 1971, MoD 1/1/1, New Zealand Defence Policy - General, 1968-1972
} 


\subsubsection{Joint Intelligence Committee Assessment - April 1971}

By April 1971 the JIC had changed its mind on the possibility of Sino-American rapprochement.

The United States... will continue efforts to come to an understanding with Communist China. The Administration has for some time been trying to improve relations with Peking and has taken some limited steps in this direction. The current re-assessment of American policy may lead to more far reaching changes including most probably a different United States approach to the question of Chinese representation in the United Nations. But in its overtures the United States will get little help from Peking itself, except possibly of a passive nature. The Administration will be subject to some pressures, both within the United States and from outside, that will tend to slow down any movement towards detente, though such pressures are not as strong as they have been in the past. And the position of Taiwan will remain a major obstacle to the improvement of relations between Washington and Peking. ${ }^{647}$

The JIC made significant note of the changes in Chinese foreign policy which it attributed to the rising Soviet threat to China. These changes were seen as highly successful for Beijing with gains in diplomatic recognition, the possibility of UN membership, and greater influence in Africa and the Middle East. Hostility to the US would remain but the JIC now saw some possibility of Sino-American rapprochement. The major barriers were perceived as American opposition to Beijing's UN membership (which could change) and the American position on Taiwan (which it thought was unlikely to change).

The JIC's examination of China's military effectiveness showed greater scepticism than earlier assessments. The JIC acknowledged efforts were being made in nuclear weapons and their delivery, ${ }^{648}$ but much less faith was placed in the fighting ability of the PLA than was evident in the New Zealand assessments of six years earlier.

Although the Chinese military stance is basically defensive its forces could overwhelm its neighbours in South East Asia or Korea if not opposed by either American or Soviet forces. In conventional combat against a modern enemy, however, each branch of the PLA would have critical weaknesses. Army units are seriously deficient in motorized transport and heavy armament; the air defence system could not withstand a large scale sophisticated air attack; and the Navy, while growing and modernizing, is still little more than a coastal defence force. With its huge reserves of

647 'The Strategic Outlook for the Pacific Area 1971-76 and Beyond', Annex to JIC(NZ)(71)1, April 1971, MoD 1/1/1, New Zealand Defence Policy - General, 1968-1972

648 'The Strategic Outlook for the Pacific Area 1971-76 and Beyond', Annex to JIC(NZ)(71)1, April 1971, MoD 1/1/1, New Zealand Defence Policy - General, 1968-1972 
trained or partly trained manpower the PLA could, however, sustain large scale guerrilla operations for a lengthy period. ${ }^{649}$

The JIC's faith in SEATO as a useful alliance had all but evaporated. SEATO's importance was considered limited to its role as 'the basis of the American commitment to the security of the South East Asian area', as it had in earlier assessments, but the JIC now did not believe that it was capable of further development. ${ }^{650}$ With the US and others stepping back from South East Asia there was little faith that SEATO could be expanded or improved into a more effective collective security architecture. By 1971 it was very unlikely that the US would be interested in any new structure for the security of the region, regardless of the level of threat from China.

The JIC's view of Chinese and SEATO weakness was set against a view that any kind of military conflict was becoming increasingly undesirable in capitals of the major powers. The US, China, and the Soviet Union were seen by the JIC as extremely reluctant to become embroiled in any kind of military adventure in Asia. Even smaller conflicts were, by then, thought by the JIC to be highly undesirable to the great powers, even between proxies. In an effort to reduce the chance of conflict on the Korean Peninsula, the US and Soviet Union were thought to be reducing their supplies of offensive weapons to North and South Korea respectively. ${ }^{651}$ The JIC seemed to view the chances of great power conflict as lower than at any time since the Cuban Missile Crisis.

The risk of low-intensity conflict (outside Vietnam) was also perceived by the JIC to be lower than it had been in previous assessments and such conflict was now judged unlikely to demand assistance by New Zealand. Even with New Zealand's potential combat operations limited to 'terrorist operations in northern Malaysia during disturbances elsewhere in the country', the government of Malaysia was expected to be reluctant to ask for ANZUK assistance in the event of such an emergency. The JIC considered interest by Malaysia and Singapore in retaining foreign forces on their territory would diminish and that the ANZUK presence may be terminated by the end of the $1970 \mathrm{~s} .{ }^{652}$ In short, not only was the threat to

649 'The Strategic Outlook for the Pacific Area 1971-76 and Beyond', Annex to JIC(NZ)(71)1, April 1971, MoD 1/1/1, New Zealand Defence Policy - General, 1968-1972

650 'The Strategic Outlook for the Pacific Area 1971-76 and Beyond', Annex to JIC(NZ)(71)1, April 1971, MoD 1/1/1, New Zealand Defence Policy - General, 1968-1972

651 'The Strategic Outlook for the Pacific Area 1971-76 and Beyond', Annex to JIC(NZ)(71)1, April 1971, MoD 1/1/1, New Zealand Defence Policy - General, 1968-1972

652 'The Strategic Outlook for the Pacific Area 1971-76 and Beyond', Annex to JIC(NZ)(71)1, April 1971, MoD 1/1/1, New Zealand Defence Policy - General, 1968-1972 
South East Asia from China and Chinese (or otherwise) inspired insurgent groups diminishing, but the need for Malaysia and Singapore to keep Australasian forces on their territory was also considered to be dropping. It was in this context that the new architecture for the New Zealand and Australian presence was created.

\subsubsection{The Five Power Defence Arrangements}

The Five Power Defence Arrangements (FPDA) were developed in the lead up to the British withdrawal from South East Asia. The FPDA came into effect on 1 November 1971 and replaced the Anglo-Malaysian Defence Agreement (AMDA) and ANZAM agreements. The arrangements were designed to create a framework for a continued New Zealand and Australian presence in Malaysia and Singapore following British withdrawal. Negotiations began in June 1968 and were ramped up after Nixon announced his Gaum Doctrine. ${ }^{653}$ Efforts to include the US in such arrangements came to naught and the UK would only play a minor role in any future structure. Britain indicated it would only deploy a significant force to the region in a crisis, but promised to continue to train in the area after withdrawal was completed in 1971. Once it was accepted that New Zealand and Australia would continue their presence in South East Asia without the UK, a structure had to be established that did not require a major power in a leading role.

Malaysia and Singapore were committed to building up their own forces and becoming less reliant on foreign support. At the start of 1969 Wellington and Canberra announced that their respective battalions would move from their base at Terendak in Malaysia, to Singapore by the end of the year. Soon afterward, the announcement came that Australasian forces would remain in Singapore after 1971, with the New Zealand forces remaining at their existing strength. ${ }^{654}$ Not unlike Nixon's policy of 'Vietnamization' - turning over fighting of the war to the South Vietnamese - New Zealand's focus had shifted from defending South East Asia from China to ensuring that Malaysia and Singapore could defend themselves from less serious threats. Increased participation by Malaysia and Singapore was also desirable given the financial pressure being felt by the New Zealand military. New Zealand was not able to increase its role in the region to compensate for Britain's departure but by the 1970s New Zealand did not believe Britain's forces needed to be replaced to the same level. New Zealand was trying to reduce its responsibilities without abandoning the region.

653 MoD, 1/1/9 Vol. 12, Talks and Arrangements with Allied Nations, October 1969-March 1970

654 'Notes on Defence', 10 September 1969, MoD 1/1/1, New Zealand Defence Policy - General, 1968-1972 
With the election of his Conservative UK Government in June 1970, incoming Prime Minister Edward Heath announced Britain would retain a small force in South East Asia after 1971. Nevertheless, Heath made it clear that the size of the remaining British force would not be sufficient to maintain the AMDA. ${ }^{655}$ By October the British commitment had been spelt out: five frigates, a battalion group (including an air platoon and artillery battery), and long-range maritime reconnaissance and helicopters. A Royal Navy submarine to be based at Sydney was later added. ${ }^{656}$ New Zealand was to provide a frigate, medium range transport aircraft, three Iroquois, one battalion, and periodic deployments of strike aircraft. Australia provided two squadrons of Mirage aircraft, one naval ship, and one battalion. ${ }^{657}$ One of the major components of the new arrangements was the Integrated Air Defence System (IADS) which was commanded by an Air Defence Commander responsible to the five governments under the terms agreed by their ministers. Aircraft for the IADS were supplied primarily by Australia, Malaysia, and Singapore, with some periodic contributions by New Zealand and the UK. ${ }^{658}$

Given the fast pace of change and the possibility that the Australasian commitment might not be long-lived, ${ }^{659}$ the FPDA was not implemented as a formal treaty. ${ }^{660}$ The only statement of intent in the original agreement is the agreement to consult in a crisis:

The Ministers also declared, in relation to the external defence of Malaysia and Singapore, that in the event of any form of armed attack externally organised or supported or the threat of such attack against Malaysia or Singapore, their governments would immediately consult together for the purpose of deciding what measures should be taken jointly or separately in relation to such attack or threat. ${ }^{661}$

This consultative basis was meant to avoid a formal alliance. ${ }^{662}$ To that effect a formal secretariat was not created but instead a Joint Consultative Council was established to be attended by the Ministers of Defence from Singapore and Malaysia, and the High

\footnotetext{
655 'Five Power Defence Arrangements', New Zealand Foreign Affairs Review, Vol. 22, No. 1, January 1972, p. 15

656 'Five Power Defence Arrangements', New Zealand Foreign Affairs Review, Vol. 22, No. 1, January 1972, p. 16

657 'Five Power Defence Arrangements', New Zealand Foreign Affairs Review, Vol. 22, No. 1, January 1972, p. 16

658 'Five Power Defence Arrangements', New Zealand Foreign Affairs Review, Vol. 22, No. 1, January 1972, pp. $17-18$

659 Rolfe, 1995, p. 6

660 The agreement remains in place as of January 2016.

${ }^{661}$ 'Five Power Defence Arrangements', New Zealand Foreign Affairs Review, Vol. 22, No. 1, January 1972, p. 17

${ }^{662}$ Rolfe, 1995, p. 6
} 
Commissioners of New Zealand, Australia, and the UK. Day-to-day consultation would be at the service and official levels. ${ }^{663}$ The new framework kept New Zealand involved in South East Asia but with an assumption that Singapore and Malaysia's reliance on New Zealand military assistance would decline. That decreased reliance would come from improvements in the capability of the Malaysian and Singaporean militaries, but also a declining risk of a major conflict with China or Indonesia requiring New Zealand and Australian support. The continued public political commitment to the defence of Malaysia and Singapore and the commitment to maintain force numbers belied more significant changes in defence policy. New Zealand would not give up on its allies in South East Asia, but the FPDA reflected a significant and continuing relaxation of the expectation that New Zealand would have to commit itself to a significant military conflict in Asia, especially against China.

\subsubsection{The Review of Defence Policy 1972}

Despite several abortive attempts, a fresh review of defence policy was finally published in 1972. The differences between the Review of Defence Policy 1972 and the previous 1966 review are striking not just for their statements on the threats faced by New Zealand, but also the intent of the two documents. Unlike the 1966 review, the 1972 review is 'not intended to promulgate decisions already made' about defence, but rather to 'provide a basis for constructive public discussion' which would facilitate future decision making. ${ }^{664}$

The significant change in the international situation was noted especially the decrease in the importance of the Vietnam War. The worsening of the Sino-Soviet split was given as the major cause of the improving security situation in New Zealand area of interest.

The Sino-Soviet schism has deepened and widened. The rivalry of these great powers in countries bordering our area of strategic concern... could have serious repercussions. China and the Soviet Union now confront each other militarily and compete with each other not only ideologically for the support of communist governments and revolutionary parties, but also diplomatically for influence with non-communist powers, especially in the development of relations with their main adversary, the United States. In other words, both the Soviet Union and China in the course of their

\footnotetext{
663 'Five Power Defence Arrangements', New Zealand Foreign Affairs Review, Vol. 22, No. 1, January 1972, p. 17

${ }^{664}$ Review of Defence Policy 1972: New Zealand's Defence Policy Perspectives, AJHR 1972 Vol. 1, A-C, A.5, p. 5
} 
manoeuvring the one against the other, have become more flexible in their foreign policies towards many third parties. ${ }^{665}$

The mutual antagonism between the two major communist powers was now seen as a benefit to New Zealand, as both wanted better relations with other countries. This is a world away from New Zealand's perspectives on China in the mid-1960s which saw China's growing hostility as paramount and the Sino-Soviet split being of little relevance. The 'diplomatic and new flexibility of China' was only rivalled by Japan's rapid economic growth. ${ }^{666}$

While acknowledging that the UK and US were retreating from their overseas commitments, the review tried to emphasise the remaining British and American ties to the region such as aid, the British involvement in the FPDA, and the American nuclear umbrella. The positive spin on Anglo-American withdrawal was tempered with a warning that the Sino-Soviet competition was heating up just as the friendly great powers were disengaging from Asia and that further disengagement was still possible.

But the possibility cannot be excluded that domestic, economic, and political pressures or political changes, in both the United States and Britain, could further affect them at the very time when China and the Soviet Union are becoming increasingly active in the competition for influence in the littoral states of the Indian Ocean, Southern Asia, and the Western Pacific. ${ }^{667}$

The international climate described in the 1972 review is noticeable for its vagueness on how the changes in the international environment would affect New Zealand's defence forces. This vagueness was acknowledged by the Secretary of Defence and put down to the fluidity of great power relationships. ${ }^{668}$ The major variable identified in the review was how the states of South East Asia were going to respond to the slackening of engagement by the Western powers. Other variables identified were the ability of the smaller states of South East Asia to cooperate, and how the Vietnam War was to be settled. ${ }^{669}$

665 Review of Defence Policy 1972: New Zealand's Defence Policy Perspectives, AJHR 1972 Vol. 1, A-C, A.5, p. 8

666 Review of Defence Policy 1972: New Zealand's Defence Policy Perspectives, AJHR 1972 Vol. 1, A-C, A.5, p. 9

667 Review of Defence Policy 1972: New Zealand's Defence Policy Perspectives, AJHR 1972 Vol. 1, A-C, A.5, p. 9

${ }^{668}$ Defence Council Minutes, 6 September 1972, MoD 1/1/1 Vol. 4, New Zealand Defence Policy - General, 1968-1972

${ }^{669}$ Review of Defence Policy 1972: New Zealand's Defence Policy Perspectives, AJHR 1972 Vol. 1, A-C, A.5, p. 9 
The theme of the Review of Defence Policy 1972 was uncertainty, but more importantly it marked significant changes in how Asia was perceived by New Zealand and how events in Asia had affected New Zealand security since the previous review was published. The changes were, of course, not all military. Parallel to the significant weakening of New Zealand's defence role in Asia was a significant debate about how and when to engage with China diplomatically.

\subsection{ENGAGING BEIJING: 1970-1972}

The rapid relaxation of New Zealand's fears about China's behaviour toward South East Asia and Beijing's renewed diplomatic efforts gave new impetus to the questions of China's UN membership and diplomatic recognition. By 1970 it was becoming clearer to New Zealand officials that the efforts to block Beijing from the UN would fail within a few years and that more and more states would abandon their diplomatic relations with Taipei in favour of Beijing. New Zealand officials realised they had to be very careful how New Zealand navigated these issues. Events were moving quickly. The New Zealand Government risked moving faster than domestic public opinion if it acted too hastily and risked becoming an international outlier if it moved too slowly as China worked to normalise its relations with the outside world.

In November 1970, Laking became concerned about the tension between a domestic proTaiwan lobby and the international tide turning towards Beijing. He thought support for the ROC had strengthened 'in key sections of the community' but the Government would have to be wary of 'being left behind in a general movement towards acceptance of Peking or of appearing simply to trail along behind the United States'. ${ }^{670}$ Gerald Hensley (the future Secretary of Defence) at the Washington Embassy wrote to Bryce Harland (the future New Zealand Ambassador to the PRC) that there was no reason for New Zealand to be a leader on the issue of China and that it was best if New Zealand moved with the herd. ${ }^{671}$ The general impression amongst senior officials at the start of 1970 was that New Zealand

\footnotetext{
${ }^{670}$ SecFA to NZPR New York, 23 November 1970, ABHS 950 W4627 Box 4243, 264/4/14 27C: Taken from Gustafson, 2007, pp. 274

${ }^{671}$ Hensley to Harland, 29 January 1970, ABHS 950 W4627 Box 4244, 264/4/14 28B: Taken from Gustafson, 2007, pp. 274-275
} 
should not lag behind Australia or the US but neither should it go too far ahead of them, especially if it meant cutting ties with Taiwan. ${ }^{672}$

\subsubsection{Holyoake's New Zealand and China}

In May 1971 Holyoake commissioned an article to express his views on the need for change in New Zealand's China policy. He acknowledged that Beijing seemed to 'have turned a new leaf' and was 'taking a more friendly attitude to the outside world'. ${ }^{673}$ Yet he wasn't willing to see China and its goals as being fundamentally different. 'No useful purpose will be served by forgetting all we have learned about China in the past and imagining that everything is now different. It never is'. ${ }^{674}$ Holyoake noted the increase in China's power in the post-war era. New Zealand geography meant that it could not ignore China:

One of the great events of our lifetime has been the re-emergence of China on the world scene. After a century of weakness and passivity, it has regained strength and begun to exert influence on others. This has changed the complexion of international politics and made the question of relations with China one of the chief issues of the day for governments all over the world. It has special importance for countries like New Zealand that are located in the Pacific area and are, actually or potentially, within the reach of China's power. ${ }^{675}$

Holyoake's statement fudges an important question: to what extent did China threaten New Zealand's interests in 1971? The use of 'actually or potentially' in a public document suggests that Holyoake was trying not to make a statement on China's level of threat. He may have been trying to strike a balance between a view of China as a continued threat to New Zealand interests in South East Asia and the idea that China was no threat at all. The article goes on to point to the right of the smaller nations of South East Asia to avoid Chinese hegemony and Beijing's unwillingness to allow for such a right. Holyoake listed the hostile Chinese acts of the 1950s and early 1960s (attacks on Taiwanese held islands in 1958, the crushing of the Tibetan revolt of 1959, and the Sino-Indian War of 1962) and its support for communist revolutionaries in South East Asia. The Cultural Revolution's exacerbation of the Sino-Soviet split was considered to be a lasting problem for China: even

\footnotetext{
672 Barry Gustafson, Kiwi Keith: A Biography of Keith Holyoake, Auckland University Press, Auckland, 2007, p. 275

673 Keith Holyoake, 'New Zealand and China', pamphlet, Ministry of Foreign Affairs, Wellington, 28 May 1971, p. 3

${ }^{674}$ Holyoake, 'New Zealand and China', 1971, p. 3

675 Holyoake, 'New Zealand and China', 1971, p. 3
} 
if Holyoake thought the Cultural Revolution was now over, its effects would continue to be felt. ${ }^{676}$

Holyoake felt the revival of Chinese diplomacy had much to do with Beijing's interests in avoiding a war with the Soviet Union. Relationships that had survived the Cultural Revolution, such as with Tanzania and Pakistan, were used as a springboard to build new relationships such as with Canada and Italy. The latter two had recognised Beijing by the time of Holyoake's article, but, as he noted, diplomatic recognition had been possible on their part only at the cost of their official relations with Taiwan. ${ }^{677}$ Holyoake even admits surprise that the US and China had not already made an accommodation with one another, given Nixon's public desire for better relations. The lack of Sino-American rapprochement as of May 1971 suggested to the Prime Minister that Beijing's return to the Warsaw Talks was entirely to unsettle the Soviets, rather than to reach a deal with the Americans. ${ }^{678}$

Ping-Pong diplomacy was, in Holyoake's view, a positive sign. The previous month a US table tennis team visited China on the invitation of Mao. Zhou told the American players that the event signified the beginning of a new friendship between the US and China. ${ }^{679}$ Nevertheless, Beijing's insistence that sporting contact represented person-to-person rather than government-to-government contact suggested to Holyoake that Beijing was pushing American public opinion to accommodate China on its terms. ${ }^{680}$ This was in line with the attitude of the New Zealand Commission in Hong Kong which saw the sporting contact as a means to soften American attitudes to China. ${ }^{681}$ For the commission it represented an attempt by Beijing to improve its image, particularly in Japan, Australia, and the US. It also noted the tournament marked a return to the pre-Cultural Revolution levels of access for Western journalists. ${ }^{682}$

Beijing's continued vocal support for foreign revolutionary groups was seen by Holyoake as an attempt to make it difficult for the Americans and the Soviets to come to an accommodation with each other against China. ${ }^{63}$ This is a strong sign that Holyoake did not

\footnotetext{
676 Holyoake, 'New Zealand and China', 1971, pp. 6-7

677 Holyoake, 'New Zealand and China', 1971, p. 9

678 Holyoake, 'New Zealand and China', 1971, p. 8

${ }^{679}$ Henry Kissinger, On China, Kindle Edition, Penguin, London, 2011, p. 231

${ }^{680}$ Holyoake, 'New Zealand and China', 1971, p. 9

681 Commission to SecFA, 28 April 1971, ABHS W4628 6958 Box 46, NYP 3/16/1 Vol. 8, Political Affairs China - General, 1971

682 R.F. Shallcrass (NZ Commission Hong Kong) to SecFA, 22 April 1971, ABHS W4628 6958 Box 46, NYP 3/16/1 Vol. 8, Political Affairs - China - General, 1971

683 Holyoake, 1971, p. 9
} 
believe that Beijing was committed to promoting revolution in South East Asia and he saw it as something that could disappear in the future. At this time some South East Asian states were reassessing the level of support the PRC gave to revolutionary movements inside their borders. The commission noted not only that Filipino journalists who, on returning from Beijing, were reporting that the Chinese saw the Filipino insurgency as an internal matter but also that PRC support for the insurgency had been insignificant. At the same time the commission noted that Beijing was trying to reassure its communist friends (such as revolutionary groups and allies like North Korea ${ }^{684}$ ) that a softening of relations with the West did not mean it was going to abandon its revolutionary ideology. 685

While Holyoake had considered New Zealand's trade prospects with Taiwan to be greater than China's for some time, he insisted that this was not the sole factor in determining recognition:

The thing that matters most, to us and to other countries, is the peace of the Pacific. It is important from this point of view that the countries of the area come to terms with Peking. It is even more important, especially for New Zealand, that a small country should not be abandoned in the face of the demands of a great power. This is why the government is resolved to maintain our existing ties with Taiwan and to uphold its right to its accepted place in the international community. ${ }^{686}$

For Holyoake, the question of Taiwan was the real impediment to diplomatic engagement with China. However, in the shorter term he realised that it was in the United Nations that Beijing would seek legitimacy in the wider world. He was still unprepared to give up Taiwan for Beijing to be seated in the UN, but did believe Beijing should take China's permanent seat on the Security Council if Taiwan was able to remain in the General Assembly. ${ }^{687}$ The Prime Minister considered the abandonment of Taiwan to be against New Zealand public opinion. Holyoake thought the New Zealand public had a high regard for the $\mathrm{UN}$ and that admission would raise the status of the PRC in the public mind and give rise to stronger calls for diplomatic recognition. ${ }^{688} \mathrm{He}$ thought this high regard came from the mission of the United Nations to protect small and weak nations from the strong and that the

\footnotetext{
684 R.F. Shallcrass (NZ Commission Hong Kong) to SecFA, 3 May 1971, ABHS W4628 6958 Box 46, NYP 3/16/1 Vol. 8, Political Affairs - China - General, 1971

685 Commission to SecFA, 21 May 1971, ABHS W4628 6958 Box 46, NYP 3/16/1 Vol. 8, Political Affairs China - General, 1971

${ }^{686}$ Holyoake, 1971, 'New Zealand and China', p. 11

687 Holyoake, 1971, 'New Zealand and China', p. 13

688 Keith Holyoake, 'Chinese Representation in the United Nations', speech, 1 August 1971, ABHS W4627 950 Box 4080, 264/4/14 33A, China: Political Affairs - Recognition of Communist China, 1971
} 
UN would fail in this mission if Taiwan were to be expelled from the organisation. ${ }^{689}$ Laking had noted a few months earlier that New Zealand's press agreed with a two-China policy and that editorials had argued Beijing should be recognised by New Zealand and seated at the UN without either cutting ties with Taiwan. ${ }^{690}$

When talking to the press in London at the time of his article, Holyoake was optimistic that both the PRC and the ROC would have to accept a two-China solution in the UN. ${ }^{691} \mathrm{He}$ told reporters of his ideal scenario: that if a two-China solution became universally accepted then there would be a path open for the PRC's admission to the UN and New Zealand's diplomatic recognition of China. Beijing's UN admission and its widespread diplomatic recognition would also force the ROC to give up its seat on the Security Council. Holyoake may have understood this was not realistic but he felt the costs of abandoning Taiwan outweighed the gains from engagement with Beijing. The Prime Minister was not looking for immediate friendly relations with China. Holyoake still had deep concerns about Chinese designs on South East Asia. He noted that South East Asian nations had, at best, poor relations with China despite China's improving relations with nations in other regions. ${ }^{692}$

On 18 May 1971 the Nationalist Chinese Ambassador to New Zealand spoke to Holyoake and told him that it was impossible for the ROC to accept a two-China policy. The Prime Minister replied that there was at that time no scope for negotiations with Beijing. Holyoake said New Zealand was still waiting for Nixon to make a statement, and that dual representation was the best means of preventing the adoption of the Albanian resolution to expel Taiwan in favour of the PRC. ${ }^{693}$

While Holyoake had long made it clear he was willing to move on the issue of Beijing's UN admission and New Zealand's official diplomatic relations, the issue of Taiwan prevented either possibility. The diplomatic questions of admission and recognition were dealt with separately from the strategic questions over the threat posed, but Holyoake's comments at SEATO suggest that Washington's weakening commitment to South East Asia had a direct impact on the desirability of diplomatic engagement with China. Moves toward recognition

\footnotetext{
${ }^{689}$ Keith Holyoake, Press Statement, 26 November 1970, ABHS W4627 950 Box 4080, 264/4/14 33A, China: Political Affairs - Recognition of Communist China, 1971

${ }^{690}$ SecFA to all posts, 26 November 1970, ABHS W5400 20358 Box 148, KL 209/1/3 Vol. 2, 1969-1985

${ }^{691}$ Keith Holyoake, Press Conference, 28 April 1971, ABHS W4627 950 Box 4080, 264/4/14 33A, China: Political Affairs - Recognition of Communist China, 1971

${ }^{692}$ Holyoake, 'New Zealand and China', 1971, p. 9

${ }^{693}$ Scott, 1991, p. 240. Original reference in 264/4/13
} 
and diplomatic relations were not automatic signs of friendship but rather moves towards the discussion of differences through normal diplomatic practice. The decision to engage diplomatically with China was also an issue on which Holyoake could provide some leadership on an even footing with other leaders rather than being a junior partner in a wider security alliance. While Holyoake's China policy was no longer dependent on American policy, Wellington nevertheless would be affected by Washington's moves to engage with China and the effect of that engagement on foreign and defence policies in the region.

\subsubsection{Nixon Goes to China}

In July 1971 Nixon announced that he would visit Beijing the following year and this been arranged by Kissinger through secret meetings with Zhou. To some extent this came as a surprise to Wellington and to New Zealand diplomats around the world. While moves towards rapprochement were not surprising, there was little to suggest a visit would be announced. The New Zealand Embassy in Washington noted that the announcement of Nixon's visit did not amount to the creation of formal relations between Washington and Beijing, nor was it a state visit. It was billed by the White House as a meeting of the leaders of two great powers to discuss important issues. ${ }^{694}$ New Zealand's diplomats had only 15 minutes prior warning of the announcement and the ROC ambassador to the US had 30 minutes. ${ }^{695}$ New Zealand officials were quick to try and collect responses from Asian partners. The Taiwanese and South Koreans were surprised and unhappy about the announcement. ${ }^{696}$ New Zealand posts in Ottawa, ${ }^{697}$ Canberra, ${ }^{698}$ and Tokyo ${ }^{699}$ all reported that the governments there welcomed the news publicly but in private expressed a mixture of feelings. The Japanese were said to be confused and the Canadians were relieved that they had established recognition first. The New Zealand Embassy in Washington accurately predicted that the news of Nixon's visit meant that the US would unofficially give up on

\footnotetext{
694 NZ Embassy Washington to SecFA, 16 July 1971, ABHS 950 W4627 4055 PM 264/2/2 11B China External Relations - USA 1971

695 NZ Embassy Washington to SecFA, 16 July 1971, ABHS 950 W4627 4055 PM 264/2/2 11B China External Relations - USA 1971

696 NZ Embassy Washington to SecFA, 16 July 1971, ABHS 950 W4627 4055 PM 264/2/2 11B China External Relations - USA 1971

697 NZ High Commission Ottawa to SecFA, 16 July 1971, ABHS 950 W4627 4055 PM 264/2/2 11B China External Relations - USA 1971

698 NZ High Commission Canberra to SecFA, 16 July 1971, ABHS 950 W4627 4055 PM 264/2/2 11B China External Relations - USA 1971

699 NZ Embassy Tokyo to SecFA, 16 July 1971, ABHS 950 W4627 4055 PM 264/2/2 11B China - External Relations - USA 1971
} 
opposing China's entry to the United Nations but would pass a losing vote against Albania's resolution to the seat the PRC and expel the ROC as a necessary gesture to allies. ${ }^{700}$

Holyoake issued a statement welcoming Nixon's announcement and expressed hope that the visit would support China's trend toward more relaxed relations with other nations. ${ }^{701}$ This sentiment seems to have been genuine. Laking wrote to the Prime Minister mentioning the desire to try and calm Japanese apprehensions about Nixon's move during coming talks with Tokyo. ${ }^{702}$ Holyoake in turn wrote to Australian Prime Minister William McMahon that the pace of improvement in Sino-American relations would be slow and that Australia and New Zealand would have time to adjust to the change and 'safeguard their own essential interests'. ${ }^{703}$ Holyoake told him that if improved Sino-American relations did emerge this would be beneficial to New Zealand.

The commission noted the difficult balancing act Beijing was walking in inviting Nixon to Beijing. After the invitation was made Beijing again had to reassure its communist friends of its ideological commitment. ${ }^{704}$ At the same time Beijing's endorsement of the suppression of insurgencies in Ceylon and Pakistan did not go unnoticed by the commission. ${ }^{705}$

\subsubsection{The Commission's View of China's Changing Policy}

In August 1971 New Zealand's representative in Hong Kong wrote directly to Holyoake and laid out the state of Chinese politics as the commission saw it. ${ }^{706}$ The Commissioner strongly emphasised the inward looking nature of Chinese governance and that periods of focus on international matters were a rare luxury allowed for when the political environment was free of crisis and the basic needs of the economy were being met.

The Cultural Revolution was an extraordinary event, just as the Great Leap Forward before it had been. Both periods demonstrated the consuming preoccupation of the Chinese leaders with the internal affairs of their

\footnotetext{
700 NZ Embassy Washington to SecFA, 16 July 1971, ABHS 950 W4627 4055 PM 264/2/2 11B China External Relations - USA 1971

701 SecFA to all posts, 16 July 1971, ABHS 950 W4627 4055 PM 264/2/2 11B China - External Relations USA 1971

702 Laking to Holyoake, 21 July 1971, ABHS 950 W4627 4055 PM 264/2/2 11B China - External Relations USA 1971

703 Holyoake to McMahon, 21 July 1971, 21 July 1971, ABHS 950 W4627 4055 PM 264/2/2 11B China External Relations - USA 1971

704 Commission to SecFA, 4 August 1971, ABHS W4628 6958 Box 46, NYP 3/16/1 Vol. 8, Political Affairs China - General, 1971

705 Commission to MinFA, 26 August 1971, ABHS W4628 6958 Box 46, NYP 3/16/1 Vol. 8, Political Affairs - China - General, 1971

706 Commission to MinFA, 26 August 1971, ABHS W4628 6958 Box 46, NYP 3/16/1 Vol. 8, Political Affairs - China - General, 1971
} 
country. The problems of governing China are immense, some would say too complex to be capable of solution, and governments in Peking have traditionally relegated foreign affairs to a secondary place. When the domestic front is quiet, with good harvests and no governmental crisis to preoccupy them, the leaders of China can, as they did in the fifties in the Bandung era and again now, devote a little more of their time to the world outside China's borders. ${ }^{707}$

The commission saw that immense changes had occurred in Chinese foreign policy. Beijing's support for revolutionary movements had become tempered by support for the suppression of revolutionary groups in Ceylon and Pakistan. China was actively seeking good relations with a Chinese foreign policy that was no longer 'bound by the straightjacket of Maoist revolutionary ideology'. ${ }^{708}$ However, the Commissioner noted that this did not mean China was going to open itself to the world economically. Its return to the accepted rules of international behaviour were 'narrowly political and tactical'. ${ }^{709}$ The shift in foreign policy was based on immediate security needs rather than ideological change.

The commissioner highlighted for Holyoake the ancient problem of securing China's borders from its neighbours. In 1971 China faced significant threats from the Soviet Union to the north, Japan and the US to the east, and India to the south. The construction of moral support in the third world and membership of the UN were described by the commission as tactical moves to offset these threats. The issue of Taiwan was bound up in this feeling of insecurity and need for limited openness. The commissioner warned that there was no indication that Beijing was willing to accept a separate 'China' in order to gain membership in the UN.

In short, the commission's view of Chinese policy was one of changing of methods but not of ultimate goals. Yet those perceived goals were not the same as those perceived by the JIC and other New Zealand officials just six years earlier. In 1965 officials saw China as looking to maximise its power by seeking to dominate South East Asia. ${ }^{710}$ By 1971 the commission was telling the Prime Minister that China was changing its foreign policy just enough to seek security and maintain its territorial integrity. The view of Chinese foreign policy presented by the Commission was not one that required the containment policies of the

\footnotetext{
707 Commission to MinFA, 26 August 1971, ABHS W4628 6958 Box 46, NYP 3/16/1 Vol. 8, Political Affairs - China - General, 1971

708 Commission to MinFA, 26 August 1971, ABHS W4628 6958 Box 46, NYP 3/16/1 Vol. 8, Political Affairs - China - General, 1971

709 Commission to MinFA, 26 August 1971, ABHS W4628 6958 Box 46, NYP 3/16/1 Vol. 8, Political Affairs - China - General, 1971

${ }^{710}$ For example, see the debates between Hunn and the chiefs over the future of South East Asia in Chapter 2.
} 
1950s and 60s but it was also a view which indicated Holyoake's vision of two Chinas would not be possible.

\subsubsection{China's Admission to the United Nations}

By the time Nixon entered office in early 1969, US public opinion had shifted with a majority of Americans now saying they would accept Communist China in the UN if the member nations voted for it. ${ }^{711}$ By 1970 Washington's goals in the UN had shifted to keeping Taiwan in the UN rather than Beijing out. This effectively meant a two Chinas policy - and aligning with Holyoake's already stated position - but Nixon realised this would not be acceptable to either Chinese government. It wasn't until 1971 that the US formally dropped its opposition to the PRC entering the UN.

New Zealand's close involvement in blocking the PRC's admission continued until the end. From a tactical point of view, New Zealand was attempting to make sure that 'The onus of rejecting a two Chinas policy should be made to fall squarely on the Communists'. ${ }^{712}$ However, the chance of preventing the Albanian resolution from passing became all the more difficult on 15 July 1971 when the announcement came of Nixon's planned visit to China. This was only a day before the Albanian resolution was again tabled at the UN with 17 cosponsors. Frank Corner agreed with US Assistant Secretary of State Marshall Green that new initiatives to keep Taiwan in the UN were now unlikely. Corner realised that the US would now probably vote against the Albanian resolution but not make any major effort to oppose it. ${ }^{713}$ The Canadians soon informed New Zealand that they would vote against an IQ resolution and any other move that would delay the admission of Beijing. ${ }^{714}$

On 2 August US Secretary of State William P. Rogers made a statement that the US would support Beijing's admission to the UN but not any resolution that would expel the ROC. This was further confirmation of the two-China policy that Holyoake had long been calling for, but the Prime Minister pushed for Beijing to take the Security Council seat from Taipei as well. Discussions in August over the wording of a dual representation resolution were intense. During that month the Nationalist Chinese Ambassador spoke to Holyoake and said his Government was now willing to accept a dual representation resolution matched with a

\footnotetext{
711 Kaufman, 2000, p. 374

712 New Zealand Permanent Delegation to the UN, December 1961, as quoted in John Scott, 'Recognising China' in Malcolm McKinnon (ed.), New Zealand in World Affairs Volume II 1957-1972, NZIIA, Wellington, 1991, p. 230

713 Scott, 1991, p. 241. Also see: NZ Embassy Washington to SecFA, 16 July 1971, 264/4/14

714 Scott, 1991, p. 241
} 
non-expulsion resolution. However, he said that Taipei was not happy about New Zealand's vocal support of settling the issue of the Security Council seat. ${ }^{715}$ Taipei was clearly trying to protect its position as much as possible while the tide turned against it.

On 9 September the Americans agreed to a 'complex' dual representation resolution with New Zealand as a co-sponsor. Australia, Japan, the Philippines, and Thailand also agreed to be co-sponsors over the next few days. However, New Zealand's Permanent Representative at the UN, John Scott, felt that Kissinger's statements on China were designed to undermine efforts to keep Taiwan in the United Nations. The announcement of Kissinger's second trip came as the UN was to begin its debate on the Chinese issue projecting an image counter to US Ambassador to the UN George H.W. Bush's efforts. The debate ran from 18-25 October. Scott's recollection of the event was not one of excitement. 'It would be as tedious to recapitulate the debate as it was tedious to listen to it', he wrote. ${ }^{716}$ When it came to the vote, there was fading confidence in the Western camp. The New Zealanders met with the Americans and the Australians on fall back positions if the vote looked as though it was lost. Wellington initially told its representatives to vote for the Albanian resolution if it looked as though it would pass. Scott resisted on the grounds that the vote could be tight and New Zealand should not be the deciding vote in favour of a resolution it had tried to oppose. Wellington agreed and told Scott only to vote for the Albanian resolution if all hope was lost. $^{717}$

On Monday 25 October the US was still expecting to win the IQ vote, but an unexpected motion from the non-aligned states brought forward the voting one day to that evening. A flurry of procedural motions followed. The US was able to get the IQ motion voted on prior to the Albanian resolution but the IQ motion itself failed. This meant that the Albanian resolution could pass with a simple majority. At this point the ROC delegation refused to take further part in the proceedings and left the chamber. ${ }^{718}$ American efforts to separate out the expulsion of the ROC from the admittance of the PRC failed and the Albanian resolution passed 76-35-17, with New Zealand included in those voting against the measure. ${ }^{719}$ With

\footnotetext{
715 Scott, 1991, p. 242

716 Scott, 1991, p. 243

717 Scott, 1991, p. 244

718 Rosemary Foot, 'US Hegemony and International Legitimacy: The Chinese Representation Issue at the United Nations' in The Practice of Power: US Relations with China since 1949, Oxford Scholarship Online, 1997, p. 46

719 Scott, 1991, p. 245
} 
Taiwan's representatives expelled, there was no longer the possibility of dual representation and resolutions to that effect were withdrawn.

In Scott's view it was a lack of effort on the part of the White House which led to the passing of the Albanian resolution. ${ }^{720}$ Nixon and Kissinger had decided that relations with Taiwan were a necessary sacrifice for better relations with Beijing. They made little effort to keep Taiwan in the UN and left the US permanent representative (later president) George H. W. Bush with little ability to lobby for greater support for Taipei's cause. New Zealand stuck to its position of keeping Taiwan represented but once the momentum swung both towards Beijing's entry and Taipei's expulsion the resolve of the Government wavered. Once the ROC had been displaced at the UN, the pressure shifted globally to the question of diplomatic recognition.

\subsubsection{Recognition, Kirk, and a New Foreign Policy}

On 11 May 1971 Australia announced that it would seek to normalise relations with Beijing, but no obvious effort was made until the PRC entered the UN. Once the PRC was seated in the United Nations the global shift towards recognising China gathered pace and New Zealand and Australia made greater efforts to engage with Beijing. Holyoake realised that public opinion would shift towards recognising China at the expense of Taiwan once the battle to keep it in the UN had been lost. ${ }^{721}$ Canberra told New Zealand privately that its diplomats in Paris had been instructed to make contact with Beijing's ambassador in Paris in order to open a dialogue. ${ }^{722}$ Holyoake also began working on establishing links with the Chinese government.

Some effort was made to establish a dialogue with Beijing through Auckland businessman Ramon La Varis who claimed to have significant contacts in Communist China. La Varis had been exploring the possibility of business and political connections with China on behalf of the government since 1970, but officials quickly lost confidence in La Varis as he lacked the discretion necessary for diplomatic work. Other New Zealand business people working in China warned against using La Varis. The Joint Intelligence Bureau did not consider him a reliable reporter of events in China, and the Commission in Hong Kong was

\footnotetext{
${ }^{720}$ Scott, 1991, p. 246

${ }^{721}$ Barry Gustafson, Kiwi Keith: A Biography of Keith Holyoake, Auckland University Press, Auckland, 2007, p. 275

${ }^{722}$ Scott, 1991, p. 241
} 
concerned he could not separate his diplomatic work from his business interests. ${ }^{723}$ Despite the serious misgivings of officials, Holyoake continued to use La Varis as an intermediary and little was achieved before the National Government was defeated in the election of November 1972. It could be questioned how serious Holyoake was in establishing relations with Beijing given his use of La Varis, but by then Holyoake nevertheless understood by this time that such relations were in New Zealand's best interests and Taipei's cause had effectively been lost.

The election of Norman Kirk's Third Labour Government made recognition of the PRC possible. Kirk was unencumbered with the decisions of the past and wanted to set a new tone for New Zealand foreign policy. Labour, like the Australian Labor Party elected at the same time, had made recognition of China an election issue. Frank Corner, as incoming Secretary of Foreign Affairs, briefed the new Prime Minister on the international issues of the day and suggested recognising the PRC and reopening the New Zealand Embassy in Moscow. This suited Kirk's desire for a more open and independent foreign policy but he was concerned about being too quick to recognise China. Kirk suggested that the government leave recognition until its second term, ${ }^{724}$ but Corner persisted and convinced him to move quickly towards recognition. ${ }^{725} \mathrm{New}$ Zealand changed its official recognition of the Government of China from the ROC to the PRC on 23 December 1972, the same time as Australia. The ROC ambassador and his staff quickly left Wellington but the establishment of relations with the PRC took a few more months. The following April the new Minister of Overseas Trade Joe Walding met Zhou. In July Walding's counterpart Pai Hsiang Kuo visited Wellington and in September Bryce Harland was appointed New Zealand's first ambassador to China. ${ }^{726}$

By 1972 recognition of Beijing and the severing of official ties with Taipei was not a radical act. After 23 years of debate, views on China inside New Zealand, as well as in global public opinion generally, had shifted dramatically in only a few years. China was no longer the enemy it had been in the Korean War, nor was it perceived as the growing hostile threat to South East Asia as it had been in the mid-1960s. Radical Maoism was still the political force dominating Chinese politics but its enmity had been directed northward to the Soviet

\footnotetext{
723 Gustafson, 2007, p. 276

${ }^{724}$ Scott, 1991, p. 246

725 Gerald Hensley, Final Approaches: A Memoir, Auckland University Press, Auckland, 2006, p. 167

${ }^{726}$ David Grant, The Mighty Totara, The Life and Times of Norman Kirk, Random House, Auckland, 2014, p. 232
} 
Union. China's growing goodwill to countries outside the Soviet-bloc also reinforced the notion that it was a country that could have constructive relations with the outside world.

The election of the Kirk government heralded more than the recognition of China. Kirk's views on international relations were fundamentally different from those of Holyoake. Kirk had long demanded a more independent, moral, and principled stance in foreign policy, ${ }^{727}$ but by 1972 National and Labour had moved much closer on China and defence policies. Significant change had occurred before the Labour Government's election. Western participation in Vietnam was ending, cuts in New Zealand defence spending had been made, Forward Defence was no longer aimed at containing China, and efforts were being made to establish relations with Beijing. Therefore, by the time Kirk entered government the differences in these areas were more in tone and rhetoric than in policy.

Kirk did not withdraw New Zealand forces from Singapore and he kept New Zealand in the ANZUS alliance. However, he did not subscribe to Holyoake's quiet diplomacy and reluctance to publicly criticise friendly powers. Kirk drew support from those that had opposed the Vietnam War and promoted a more distinct sense of national identity. ${ }^{728}$ When in December 1972 Nixon resumed the bombing of North Vietnam to force the North Vietnamese to resume peace talks, the new Prime Minister sent Nixon a telegram to protest the bombing. ${ }^{729}$ There was a similar discomfort with the region's defence organisations, an attitude made clear in the extensive 1974 'Basis of Defence Policy, Planning, and Programming' report.

[The Government] has lent encouragement to the development, in the longer term, of a new, comprehensive forum for regional cooperation to replace the old, cold-war institutions that have perpetuated divisions among the countries within the region, to bring the large northern powers of China and Japan into fruitful contact with the smaller countries of South-east Asia and the Pacific. ${ }^{730}$

While the report accepted that it was still premature to create such a forum, this attitude represented a Labour Government that had determined it could and should try to break with

727 Grant, 2014, p. 231

728 Grant, p. 131, 231

729 Roberto Rabel, New Zealand in the Vietnam War, Auckland University Press, Auckland, 2005, p 331 Gough Whitlam did the same. While Kirk's protest generated a reply from Nixon that was (according to Corner) 'sharp and aggrieved', Canberra's note sent Nixon into a rage, possibly because of Whitlam's severe public criticisms of White House policy. http://www.theaustralian.com.au/news/inquirer/goughwhitlams-incendiary-letter-to-richard-nixon-on-vietnam/story-e6frg6z6-1227329039177

730 'A Basis of Defence Policy, Planning, and Programming', Draft 1, June 1974, MoD 1/1/2 Vol. 9, New Zealand Defence Policy - Review of Defence Policy 1972-1975 
the divisions of the Cold War and foster communication between all of the states of Asia and the Pacific. Emphasis would be placed on confidence building measures, 'stability, cooperation, and partnership, rather than... military commitments in security treaties which were established during the period of Great Power confrontation'. ${ }^{731}$

Kirk's desire for change mirrored the rapidly changing global environment. Britain's admission to the European Economic Community, the end of Bretton Woods, and (later) the oil shock all brought significant economic change. These social, economic, and political changes of the early 1970s had an impact on the ability of officials to make assessments for foreign and defence policy planning. When asked to produce a report on the global environment into the $1980 \mathrm{~s}$, the JIC produced a wide ranging and vague report. ${ }^{732}$ China was now assessed much more in terms of its role as a great power, but it was not the growing threat that it had been portrayed as in the mid-1960s. Its interests were still considered by the JIC to be counter to those of New Zealand, but the problem of China seemed further away than it did in the 1960s and it was described much more like the Soviet Union had been during that period.

It is unlikely that either of the communist Great Powers will be able to establish itself sufficiently in either Asia or the Pacific to put our economic interests and communications routes at its mercy. It is quite possible, however, that the Soviet Union could develop contact in the Pacific which would be contrary to our interests. The growth of Chinese influences in South East Asia and possibly the Pacific would also be detrimental to us, if less immediately close at hand. They could both be expected to exploit divisions and tensions between developed and developing countries. ${ }^{733}$

The potential for major conflict between China and either the Soviet Union or the United States was by 1973 seen as part of the superpower strategic balance, despite acknowledgement that China's military and nuclear capabilities would be inferior to those of the US and Soviet Union for some time. The rise of Japan's economic power was noted by the JIC but it was considered to be oriented towards self-defence. ${ }^{734}$

\footnotetext{
731 'A Basis of Defence Policy, Planning, and Programming', Draft 1, June 1974, MoD 1/1/2 Vol. 9, New Zealand Defence Policy - Review of Defence Policy 1972-1975

732 'Environment of the 1980s', JIC Report to CoDS and SecDef, 9 March 1973, MoD 1/1/2 Vol. 9, New Zealand Defence Policy - Review of Defence Policy 1972-1975

733 'Environment of the 1980s', JIC Report to CoS and SecDef, 9 March 1973, MoD 1/1/2 Vol. 9, New Zealand Defence Policy - Review of Defence Policy 1972-1975

734 'Environment of the 1980s', JIC Report to CoS and SecDef, 9 March 1973, MoD 1/1/2 Vol. 9, New Zealand Defence Policy - Review of Defence Policy 1972-1975
} 
The problem of China's desire to seek influence in South East Asia was not moderated by greater faith in the stability of South East Asia. The JIC believed Thailand would to come to an accommodation with China, Singapore's economic success would warm its relations with its neighbours, ethnic division would limit Malaysia, the Philippines would be beset with 'political anarchy', and Indonesia would be challenged by Java's social and economic problems. ${ }^{735}$ China would continue to (at least) inspire insurgencies in South East Asia and these would continue through the 1980s. ${ }^{736}$ In general, the JIC thought the southern half of the region had better prospects for stability than the northern half. Despite noting these significant challenges, the JIC no longer considered instability in South East Asia to be a threat to New Zealand's interests in the way it had been in the 1960s. With instability in the region less of a concern, the influence of China was also less of a concern, especially as Beijing was thought to have moderated its policies in the region.

\subsection{CONCLUSION}

The period between 1969 and 1972 saw the focus of New Zealand's China policy shift from the realm of defence to that of foreign affairs. When the focus was on containment there were few political decisions relating directly to China that needed to be made; diplomatic effort was exerted on the allies, especially the powerful ones. External Affairs kept watch on events in China, but it was in defence policy where China policy was made. Trade was limited and while the Government made no effort to restrict trade with Communist China, it did little to encourage it either. ${ }^{737}$ With Chinese containment no longer possible, the focus of China policy shifted to the more diplomatic concerns of UN admission, diplomatic recognition, and the thorny issue of Taiwan.

Finding a solution to China's diplomatic isolation became all the more desirable as China emerged from the difficult period of the Cultural Revolution. While the initial period of the Cultural Revolution put paid to the view China was a growing and expansionist power, its decline made diplomatic dialogue possible and a desirable strategy for managing China's power. Opening a dialogue with China was not desirable or easily achievable when the revolution was at its xenophobic height, but thinking changed rapidly as soon as Beijing

\footnotetext{
735 'Environment of the 1980s', JIC Report to CoS and SecDef, 9 March 1973, MoD 1/1/2 Vol. 9, New Zealand Defence Policy - Review of Defence Policy 1972-1975

736 'Environment of the 1980s', JIC Report to CoS and SecDef, 9 March 1973, MoD 1/1/2 Vol. 9, New Zealand Defence Policy - Review of Defence Policy 1972-1975

737 Roy Gordon Shuker, 'New Zealand Policy and Attitudes Toward Communist China', MA Thesis, VUW, January 1971, p. 190
} 
transformed into an active participant in international diplomacy. In the absence of a serious containment strategy there was little reason not to attempt a dialogue with Beijing. This is not to say diplomatic engagement during the period of containment would have been impossible, but the perception China was a significant threat to Western interests in South East Asia was still a significant impediment to diplomatic recognition.

The context of Forward Defence may have been specific to New Zealand and Australia, but the move toward diplomatic recognition of China was global. New Zealand's view of China changed radically between 1965 and 1971 but unlike Australia, the US, and Japan, New Zealand did not have to move its official stance as much. Holyoake's position of making the status of Taiwan the only stumbling block made New Zealand's position less hostile to Beijing when UN admission and widespread diplomatic recognition became likely. Nevertheless, Holyoake's commitment to Taiwan meant official relations with Beijing were unachievable while he dominated New Zealand foreign policy.

It is not easy to judge whether Holyoake believed genuinely that any kind of two-China solution could have been possible. His feeling that public opinion would not support the abandonment of Taiwan was at least supported by the attitude of the New Zealand press. The commission and others warned that neither the PRC or ROC would accept dual recognition but, despite Holyoake ${ }^{738}$ making moves toward recognition, it would take a new government to make a break with Taiwan. Kirk did not enjoy breaking ties with Taiwan; he had a good relationship with the Konsin Shah, the ROC ambassador to New Zealand. ${ }^{739}$ However, unlike Holyoake, Kirk was willing to sacrifice New Zealand's ties with Taiwan in order to normalise relations with Beijing.

The shift towards normalising relations with China was not helpful to the bureaucratic interests of the defence forces. While the shift in popular opinion against the war in Vietnam and the growth in the peace movement had undoubtedly an effect on the Government's defence policies, the lowered level of perceived threat helped move the hand of the Government, which had always looked for ways to reduce defence costs. Without China to provide a central threat, or SEATO providing a framework for capability choices, New Zealand no longer had obvious goals for its defence spending. Uncertainty came to

\footnotetext{
${ }^{738}$ Holyoake retired as Prime Minister in February 1972 but stayed on as Minister of Foreign Affairs until National's defeat in December that year.

739 Grant, 2014, p. 232
} 
dominate the strategic policy-making apparatus and this allowed the Government to keep firmer control over government expenditure.

The most assuring event in this climate of uncertainty was the finalisation of the Five Power Defence Arrangements as the successor to AMDA following British withdrawal. The FPDA in one sense was the result of British imperial decline, decolonisation, and the emergence of Singapore and Malaysia as successful independent states, but it also was the result of a decreased threat from China. New Zealand responded to the challenge of British withdrawal not by increasing deployments to Asia, but by decreasing them. While abandoning South East Asia had been a possibility, New Zealand remained committed to Forward Defence but it could only do so because the goals of Forward Defence had narrowed. While Australasian forces are no longer deployed in Asia the FPDA continue today as the basis of defence cooperation between its Australasian and South East Asian members. ${ }^{740}$

740 Damon Bristow, 'The Five Power Defence Arrangements: Southeast Asia's Unknown Regional Security Organization', Contemporary Southeast Asia: A Journal of International and Strategic Affairs, Volume 27, Number 1, April 2005, pp. 1-20 


\section{CONCLUSION}

The period between 1965 and 1972 saw dramatic changes in New Zealand's foreign and defence policies. This thesis has demonstrated that New Zealand's understanding of China was a crucial element in that change. In 1965 New Zealand's defence community saw itself facing the threat of conflicts in Indonesia and Vietnam with a risk of the latter conflict escalating to involve China. Much of New Zealand's capital equipment (especially the aircraft) was obsolete and significant funds were deemed necessary to equip New Zealand's forces to defend South East Asia. By 1972 most of the upgrades had arrived but the strategic situation had changed significantly. The Vietnam War had killed the public appetite for military engagements in South East Asia, but many of the influences on New Zealand's grand strategy and decisions taken were unrelated to public opinion. The primary justification for Forward Defence - the containment of China - had disappeared in favour of a number of more limited goals.

These limited goals were the direct result of the loss of the means of providing containment and the reduction in the perceived level of threat from China. In 1965 Forward Defence was an all-or-nothing concept: permanent deployments to South East Asia were seen as pointless without great power support. By the end of 1968 that view had disappeared as the threat level had declined. Forward Defence without major British or American support became tenable because the containment of China was no longer its objective, as China was not perceived to be the threat to the region it had been. Forward Defence continued, but its goals had changed. The primary focus had shifted to developing the Malaysian and Singaporean militaries and providing training opportunities for the New Zealand forces, not deterring China. The establishment of relations with China did not mean that the perceived threat from China had vanished completely. There were still lingering concerns, but given the changes in Chinese foreign policy and the inability of New Zealand to maintain a serious containment policy, there was no longer a good reason to withhold diplomatic recognition. Diplomatic engagement with China had become the best method of working through differences.

New Zealand's officials saw the China of 1965 as a state using its increasing power to dominate South East Asia and expel Western influence. In 1972 New Zealand officials still 
felt China desired to expand its influence in the region but Wellington was now much more sceptical of China's potential power and much more confident of Chinese restraint.

\subsection{THE NATURE OF THE THREAT}

The basic premise that drove New Zealand strategic thinking between 1945 and 1972 was the need to avoid a repeat of the Second World War. The fear was that an alien and hostile power could quickly dominate all of South East Asia (as Japan had done) and thus place Australia and New Zealand in peril. Initial post-war fears of Japanese rearmament were displaced by fears of China by the middle of the 1950s. From the Korean War to the peak of American involvement in the Vietnam War, New Zealand officials believed South East Asia's security was threatened by China both directly, through the PLA, and indirectly, through the support of revolutionary movements. Indonesia provided another source of threat, especially during the Confrontation period of 1963-1966. However, while Indonesia was the immediate danger in 1965, officials correctly believed that Confrontation was unlikely to continue, but incorrectly believed China would continue to increase in both power and hostility.

The term 'domino theory' never appears in any of the documents examined for this research. Such a description belies the more complex lens through which New Zealand officials examined the security problems of South East Asia. The fall of one Asian state to communism was not seen as automatically making it more difficult to prevent communism spreading or coming under the influence of China. The important element for officials was commitment. If Western powers, including New Zealand, could stay committed to the defence of South East Asian states, then those states would be unlikely to turn towards China. In turn, New Zealand needed to show commitment to South East Asia in order to maintain the British or American military presence thought vital to containing China.

The downfall of these perspectives came with the downgrading of China as a threat. Once the Cultural Revolution was in full swing there was no longer any real or potential 'first class Asiatic power' on the horizon that was likely to have the ability or the desire to control the approaches to Australia and New Zealand. China was still hostile but it was not a threat that looked as though it was likely to be able to dominate the region. Soviet power was distant, Japan was re-emerging but aligned with the Western bloc, and Indonesia had become strongly anti-Chinese, anti-communist, and somewhat pro-Western. Nuclear 
weapons, especially via improvements in Soviet and Chinese capability, were also changing New Zealand's assumptions but there is little specific detail on the role of nuclear weapons in the files examined for this research. These forces affecting New Zealand policy were also part of the much wider emergence of détente in the 1970s which reduced tensions and changed the way the Cold War was conceptualised. The notion that New Zealand's security interests were tied to avoiding a repeat of the Second World War in South East Asia waned but there were no new frameworks for understanding international security and its ramifications for New Zealand.

\subsection{The Loss of AlLiance Structures}

The process that produced the Review of Defence Policy 1966 highlighted New Zealand's utilisation of, if not reliance on, the structures created by the Western alliances and partnerships that were involved in South East Asia. ANZUS provided New Zealand's ultimate security guarantee but it provided nothing in terms of day-to-day military planning. SEATO provided the important link to American military planning. Its war plans were useful for New Zealand to help it determine where it should spend its limited defence resources as New Zealand could fill small gaps in capability amongst its partners. SEATO also gave New Zealand confidence that its interests in the region were being protected by major Western powers and that preparations were made in case of a number of contingencies including a major invasion of South East Asia by China. Correspondingly, ANZAM and the AMDA provided the basis for the Commonwealth Strategic Reserve and day-to-day organisation and logistics. This was not an ideal setup for New Zealand planners but it covered all of New Zealand's needs for South East Asian security.

The period between 1965 and 1972 saw the breakdown of all these structures and their partial replacement with new frameworks. SEATO was already suffering in 1965 from the effective loss of France and Pakistan and the alliance would lose much of its relevancy after the United States' unilateral intervention in Vietnam. It would continue to weaken until its dissolution in 1977. The replacement of the CSR, ANZAM, and the AMDA with the FPDA took many years of negotiation and was only successful - at least from New Zealand's perspective - due to the decline of the threat from China.

At the same time New Zealand's limited participation in the Vietnam War provided the greater cooperation with the United States that New Zealand defence officials were seeking, 
but it seems to have done little to improve the security of Malaysia or Singapore in the minds of New Zealand officials. By 1968 the war was seen as a significant strategic problem in its own right and not an extension of the containment of China as it had been in 1965. In fact, New Zealand officials blamed the Vietnam conflict for the loss of American interest in actively defending the region generally. While New Zealand had reluctantly joined the Vietnam War in order to shore up American support for the region, the war had the opposite effect of exhausting American interest in fighting conflicts on the Asian mainland.

The period between 1968 and 1971 were especially difficult for officials as the old security structures were failing but new ones had not yet been developed. Even with the establishment of the FPDA the Review of Defence Policy 1972 is marked by its uncertainty. New Zealand in 1965 was sure of its defence needs and what was required to maintain its interests, but by 1972 those certainties had disappeared. There was no major significant threat on the horizon, but there was also no real architecture in the Western Pacific to meet such a threat if it did emerge. New Zealand had to find its own way in terms of capability development and that meant a continued commitment to Forward Defence but a detuned version of Forward Defence connected to much more limited goals.

\subsection{CATEgorisation OF THE CONFLICT}

Wellington's relative confidence in the alliance structures of 1965 allowed for clear categorisation of armed conflicts that might appear in South East Asia and the circumstances in which New Zealand could take part. This clear taxonomy would be lost with the breakdown of South East Asian alliance structures during the late 1960s. Clear distinctions between global, limited, and low intensity warfare allowed for predictions on the likelihood of each of these types of warfare which, in turn, allowed for recommendations for capability development. With global war considered highly unlikely, the focus was placed on the somewhat higher possibility of limited war with China and the ongoing high level threat of low-intensity conflict. While China in 1965 was thought to be at least partially responsible for the low intensity conflict in South East Asia, it was the threat of limited war that drove the policy level discussions of the threats New Zealand forces should be designed to meet.

With the drop-off of the threat from China, prospective British withdrawal, American fatigue, and the Vietnam quagmire, the categories of conflict were replaced by a missionbased approach. This focused on what the defence force needed to do in South East Asia 
rather than the types of conflicts that New Zealand might find itself involved in. By 1968 the focus was on Vietnam and similar emergencies and defence cooperation with Malaysia and Singapore. Limited war was now much less likely and less of a priority for defence officials. In reality this meant that from 1968 New Zealand considered itself far less likely to enter into an armed conflict in South East Asia once the Vietnam conflict had concluded, despite Forward Defence continuing.

\subsection{ReLATIONSHIP WITH BRITAIN AND UNITED StATES}

The driving force behind New Zealand's Forward Defence strategy was the country's relationship with its allies, especially the UK and the US. The English-speaking great powers were, in New Zealand's mind, vital to the containment effort, but both lost interest in active military support for South East Asia during the 1965-1972 period. New Zealand had to navigate the very different China policies of the UK and US. The UK's diplomatic presence in Beijing was an important source of information for New Zealand even if New Zealand was closer to American policy on China during this period. New Zealand's day-today military needs were met with the cooperation of the UK while the ultimate security guarantee was provided by the US. Once British withdrawal was confirmed attention moved to gaining American support for New Zealand's efforts in Malaysia and Singapore, something that New Zealand and Australia failed to achieve.

Willingness to support major allies defend their vital interests was an important element of New Zealand's foreign policy. This was considered necessary if New Zealand was to expect the protection of great powers in an emergency. However, the difference between supporting the interests of allies and convincing allies to support New Zealand's own interests was not always clear. Often great power support was seen as an end in itself and not a means to furthering New Zealand's own interests. Nevertheless, it cannot be said that during 19651972 New Zealand's Forward Defence strategy was solely or even primarily about maintaining the ANZUS alliance security guarantee. New Zealand needed the great powers to further its own interests in the region much more than Britain and the United States needed New Zealand's assistance. Officials in Wellington, especially in the years 19651968, were deeply concerned about the loss of British and American support and the effect that would have on New Zealand's interest in maintaining the security of South East Asia. The relaxation felt by New Zealand officials after 1968 was due to the decrease in perceived threat from China not because of reduced British and American interest in the region. 


\subsection{DECOLONISATION}

Forward Defence was a strategy that facilitated, but was also undermined by, the process of decolonisation. New Zealand wanted South East Asia to be secure from domination by a hostile power. In the early years of Forward Defence this meant protecting Britain's colonial possessions, and to a somewhat lesser extent the SEATO members and protocol states of South East Asia. As time went on, Forward Defence became about supporting the defence of Malaysia and Singapore. This meant significant engagement with the new states and assistance to help build their own defence capabilities. Optimism among New Zealand officials on the prospects for Malaysia and Singapore as independent states was never high during the late 1960s, but by the early 1970s the reality of Anglo-American withdrawal demanded greater confidence. Such confidence was also sounder due to the reduction in threats from both China and Indonesia. However, the files examined for this research do not give a clear sense that officials believed Singapore and Malaysia were ready to pick up their own defences. It was simply the political reality of the situation. The lack of support from the great powers meant that the young states had to put more effort into their own defences whether they were capable or not.

Forward Defence had value when the states of South East Asia were weak and the threats to those states were high. As Malaysia and Singapore became somewhat stronger and the threats receded, Forward Defence lost its importance. British withdrawal and the Guam doctrine may have forced New Zealand and Australia to do without great power support but it also meant Malaysia and Singapore needed to set up their own defence independence. In this sense Forward Defence was a successful strategy. The states of South East Asia became strong enough that they no longer required a significant injection of foreign military support.

\subsection{The NZ Commission in Hong Kong and the Cultural Revolution}

The New Zealand Commission in Hong Kong was instrumental in providing sound analysis during the Cultural Revolution. Unlike defence officials, the officials of External Affairs acknowledged the sources that informed their opinions when writing to Wellington. This gives a clear picture of the connections New Zealand diplomatic officials utilised to understand events in China. New Zealand did not have officials on the Chinese mainland, but it did have friends such as the British and the Indians who had posts in Beijing. Critical analysis of press reports and utilisation of the few New Zealand business people trading 
with China also provided important information. However, the view from Hong Kong could skew knowledge in favour of events in Hong Kong and Guangdong. The danger to Hong Kong may have dominated the perspective of the commission in 1967 but it also built a picture of the Chinese leadership that was still in charge of foreign policy and could restrain revolutionaries. This was not a view of irrational leadership and uncontrolled chaos, but a view of a leadership where there was hope of engagement and diplomacy. This perspective only became stronger in the years before New Zealand established relations with China.

It was the commission that drove changes in External Affairs' (and perhaps Wellington's) thinking on China and provided the analysis of the Cultural Revolution. It was the revolution that broke the notion that China was an uncompromising expansionist power which was willing and would eventually be able to push away Western power and influence in South East Asia. This breakdown came in two phases. The first phase was brought about by the tumultuous period of the revolution from 1966 to 1968. In this period China may have become even more belligerent to the West but it also became more isolationist. The breakdown of social order in China and that breakdown's perceived (but in reality minimal) effects on the economy tore away at the idea in New Zealand officialdom that China was a unified force capable of significant economic growth which would eventually be directed at dominating South East Asia. The chaos of the revolution and the internal conflict made external adventures or meaningful direction of external revolutionary groups unlikely. A China at war with itself was unlikely to be able to create or muster the hard and soft power necessary to dislodge the Western powers from South East Asia.

The second phase was brought on by Beijing's change in foreign policy after the dampening of the social disorder and the suppression of the Red Guards. The growing hostility between China and the Soviet Union seeded the idea in Wellington that a three-way Cold War between Moscow, Beijing, and Washington was unsustainable. That idea took some time to grow but by the middle of 1971 it was looking likely that Mao would reciprocate Nixon's offer of improved relations. China was still seen by officials as actively hostile, but by then it was not only working within the norms of accepted international behaviour but also heading towards some kind of accommodation with the US. China had become a country with which New Zealand and other Western countries could have meaningful diplomatic relations. The violent demonstrations that had targeted foreign - especially Soviet and British - diplomats in Beijing had ended and the Chinese Government's fiery international rhetoric had been toned down significantly. 
With the decline of the Cultural Revolution, New Zealand officials saw the multiple difficult lines Beijing had to walk. China's leadership had to maintain a balance between the revolutionary hard-liners and the more moderate influences of Zhou. Beijing also had to walk a line between easing tensions with the West and abandoning the leftist revolutionary movements around the world which Beijing claimed to support spiritually if not always materially. Chinese foreign policy had shifted from hostility to the outside world to a mixture of ideological pronouncements, a charm offensive, and a moderation of its support for revolutionary movements. Beijing's emergence from isolationism after 1969 meant that it placed more effort in seeking favour amongst the states of South East Asia rather than seeking to undermine them. All of this amounted to a view of China that required diplomatic engagement and not active military containment.

\subsection{The RoAd to DÉTENTE: AdMISSION AND RECOGNITION}

The existing literature on New Zealand's China policy places significant emphasis on issues of UN admission and diplomatic recognition. This is understandable given these issues dominated public discussion of New Zealand's China policy during the period and the paucity of open sources on defence policy. However, with access to the documents used for this research it is clear that there were significant changes in the defence establishment's perception of China around 1968. At this point China ceased to be the primary strategic concern to the defence establishment, a change in attitude probably driven by the information flows coming from External Affairs. This moved the debates about China policy out of the defence realm and added importance to the debates about China policy occurring in the Ministry of Foreign Affairs. From 1969 China was primarily a diplomatic issue rather than a military one. This brought the issues of admission to the UN and recognition to the fore for New Zealand policymakers. China's re-entry into international diplomacy from 1969 added impetus to calls for Western countries to normalise relations with Beijing.

New Zealand was not a leader in recognising China. It voted against General Assembly Resolution 2758 which admitted Beijing to the UN at Taipei's expense and New Zealand kept to the middle of the pack of Western countries recognising and establishing relations with Beijing. Yet, at the same time, New Zealand was in a much better position to establish diplomatic relations having given up on a strategy of containment. Direct engagement with Beijing had become the obvious strategy furthering New Zealand's interests, but for Holyoake dual recognition continued to be a significant stumbling block. If Beijing and 
Taipei had been willing to compromise on the issue of dual recognition, then New Zealand's recognition of Beijing would have occurred sooner. Only when a move at the cost of Taiwan became acceptable domestically did Holyoake begin to move towards recognition. The new Labour Government had the advantage of not being tied to previous decisions and thus could more easily make the decision to switch recognition from Taipei to Beijing.

This research found little evidence to support the notion that New Zealand's China policies were a direct result of Washington's position on China. That is not to say the American position was irrelevant, but it was only one of several considerations the Government had to weigh in managing China policy from 1969. Certainly there were misgivings about Nixon's lack of consultation with his allies before announcing his trip to Beijing. However, this does not mean New Zealand was simply being led by Washington on China policy. Holyoake genuinely welcomed the prospect of Sino-American rapprochement as the United States appeared to have moved closer to Holyoake's position of dual recognition. New Zealand was not looking for American approval to recognise the PRC but Nixon's visit was part of a wider international swing towards Beijing that would isolate New Zealand should it fail to make the transition.

The transition of China policy from the Defence realm to Foreign Affairs placed more emphasis on Cabinet to make decisions. In the mid-1960s the defence review process dominated China policy with officials making sober judgements based on detailed intelligence to plot the strategic direction with the supervision and endorsement (but not the complete financial backing) of the political leadership in Cabinet. With the decline of China as a threat, Holyoake became more directly involved as a solution to the PRC's diplomatic isolation became more feasible. The power shift of China policy away from the defence establishment was part of a wider decline in influence of the military in the early 1970s as Cabinet cut funding increases in the midst of significant anti-military public sentiment.

Vietnam, the end of containment, and the emergence of détente weakened the defence element of New Zealand foreign policy. This in turn allowed a more openly independent foreign policy. While Kirk had long held that open disagreement with American policies did not imperil the alliance, the breakdown of American interest in active military participation in Asia and the drop-off in threat from China provided greater opportunity for dissent. By the 1970s New Zealand had no hope of the US underwriting the defence of Malaysia and Singapore and given the change in attitudes towards China, New Zealand had little to bargain with the Americans on defence policy. The Americans no longer needed New 
Zealand for support in Vietnam and New Zealand no longer needed the US for the containment of China. The criticisms of White House policy that Kirk made upon entering office could do far less damage to New Zealand's defence interests in the 1970s than it might have done in the 1960s.

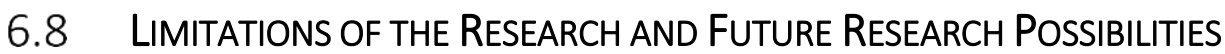

This work has utilised newly declassified policy documents from the defence review processes of the late 1960s and early 1970s. These documents have generated new knowledge about the assumptions about China and New Zealand security that drove defence and foreign policy during this period. What is innovative is the insight into the interface between the top military leaders and senior bureaucrats on defence and foreign policy in this period. There are, however, some limitations in this material. There is little discussion in this material about Australian policy. This is not limited to defence matters. There is very little material from the Canberra High Commission in the files relating to China and Hong Kong in the 1960s. This changes in the 1970s, especially during the lead up to Beijing's admission to the UN. At that time Australia shared a significant amount of material with New Zealand officials.

It is very clear that New Zealand independently assessed the international situation and determined how best to pursue its interests with the resources it had available. What is less clear is how distinct New Zealand policymaking was from its allies, especially Australia. In many ways New Zealand's strategic problems were the same as Australia's. New Zealand's Forward Defence strategy was as reliant on Australia as it was the UK or the US. It is clear that New Zealand was not simply imitating the strategic policy of Australia or any other country, but more work is required to determine how Australian thinking on China moved during this period in comparison with New Zealand. A comparative study of official New Zealand and Australian attitudes towards China during this period would be useful.

Where New Zealand policy did to some extent imitate other countries was on the timing of recognition of the People's Republic. Like many other capitals, Wellington established relations with Beijing following the PRC's admission to the United Nations. There is no doubt that Marshall's government (with Holyoake still serving as Minister of Foreign Affairs) was heading towards recognising Beijing before its election loss. Kirk's initial reluctance to recognise Beijing immediately is hard to explain. It is possible that Australia's 
decision to establish relations with Beijing played a part in changing the new prime minister's mind. The opening of more files related to the decision to recognise Beijing would shed more light on the matter.

What is striking about the discussions in defence policymaking bodies during this period is the lack of discussion of public opinion. References to public views are rare in the files examined for this research and evidence of significant linkages between defence officials and civil society is weak. Certainly the public criticisms of the Vietnam War seem to have had little impact on the recorded debates of the Defence Council or the Chiefs of Staff Committee. This makes it difficult to ascertain the extent to which public opinion influenced the thinking of defence policymakers. A study comparing public attitudes towards China and those of government officials would be valuable. The linkages between Cabinet and the officials is not always clear either. Certainly Defence Minister David Thomson was a strong advocate for the military in Cabinet but the relationship with other Cabinet members is not always clear. Holyoake had a significant interest in China policy but his relationship to the defence side of China policy is less clear. Nevertheless, the defence reviews were accepted by Cabinet with only the financial implications being a point of contention.

Undoubtedly, the New Zealand Commission in Hong Kong played a crucial role in New Zealand's understanding of events in Communist China. The challenge of assessing events in China was felt in many, if not all, foreign capitals. The initially inexplicable chaos of the Cultural Revolution was a particularly difficult puzzle for outside observers to decipher. New Zealand's partners shared what little information they had. Nevertheless, it would be possible to conduct a much wider analysis of Western assessments of the Cultural Revolution. Understanding how Western capitals built a picture of the Cultural Revolution would be valuable in assessing how governments make foreign policy with limited information.

\subsection{FINAL THOUGHTS}

This work has added significantly to the academic literature on China and New Zealand grand strategy. For a small power like New Zealand, grand strategy is more than simply seeking alliances. New Zealand had limited resources and had to place them in the best position possible to maximise their value in protecting New Zealand's interests. This work has showed that such strategic calculations are possible for smaller actors, albeit with a 
narrower range of options. The declassification of the files relating to the defence review processes of the late 1960s have provided new insight into New Zealand's strategic assumptions that had not previously existed in the literature. The role of China as a strategic threat has been mentioned by authors such as Rabel ${ }^{741}$ and Dickens. ${ }^{742}$ Their work provides the strongest statements about the role of China in New Zealand's thinking on the Vietnam War. However, the documents of the defence review process provide a much clearer picture of New Zealand's overarching strategic thought. China is the clear long-term strategic threat to New Zealand's interests in 1965. It was not a direct threat to the New Zealand area but any threat to Western interests in South East Asia was considered an unacceptable risk to New Zealand security. The change in New Zealand's thinking on China during and after 1965 is the crucial element in the country's strategic thinking that has been previously underestimated by scholars.

Brady's assertion ${ }^{743}$ that New Zealand governments were unconcerned about China as a threat (until at least 1968) is untenable. While this study has not examined the person-toperson links explored by Brady, this research demonstrates clearly that China was considered by policymakers to be the significant external security threat to New Zealand. Brady's proposition may still hold if her conclusion is narrowed to argue that China was not thought to be a significant internal security threat. Internal security was not the subject of this research, but it has not uncovered any information that would suggest that China posed a risk to internal security in New Zealand.

The fear among New Zealand officials of South East Asia being dominated by an alien great power was forged from Japan's sweeping occupation of South East Asia. By 1970 that memory had begun to fade. The need to expend significant national resources to defend the Malay Peninsula was looking less and less like an essential element of New Zealand's defence. With the failure of New Zealand's attempts to keep the friendly great powers involved in the region, New Zealand was faced with a situation where the only option was to reassess its interests. With the loss of the means of the strategic equation the ends had to be re-evaluated.

\footnotetext{
741 Rabel, 2005

742 Dickens, 1995

743 Brady, 2005, pp. 131-153; and Brady, 2008, pp. 1-20
} 
Gustafson $^{744}$ and Pugsley ${ }^{745}$ have noted that New Zealand's military contributions to Asia were not meaningful in determining the outcome of conflicts or potential conflicts in the region. For that reason, Gustafson and others saw Holyoake's defence policy as being simply an element of foreign policy: a strategy that provided small contributions to conflicts that were timed to have the biggest impact on foreign policy goals. However, this view forgets the nature of strategy and Clausewitz's dictum that 'war is a mere continuation of policy by other means'. ${ }^{746}$ Defence policy always serves foreign policy. It is correct to say that New Zealand's efforts were designed to maintain the alliance with the US but this view is as simplistic as it is incomplete. It is incorrect to state New Zealand sent forces to distant shores of little interest to itself in order to maintain a security guarantee just in case of an unlikely invasion. The reality is the reverse. New Zealand determined that the stability of South East Asia was vital to its national interests, determined China was the biggest threat to that stability, and used the few tools it had at its disposal to try and keep the Englishspeaking great powers involved in the region. Wellington feared - with good reason - that the US and UK would tire of the South East Asian entanglements. From Wellington's perspective it was the Americans and the British that were being dragged to distant shores where their interests were fading, not the other way around.

\footnotetext{
744 Gustafson, 2007, p. 212

745 Pugsley, 2003, p. 336

746 von Clausewitz, 1997, p. 22
} 


\section{Ministry of Defence Files}

MoD 1/1/1 Vol. 1, New Zealand Defence Policy - Policy - General, 1961-1968

MoD 1/1/1 Vol. 2, New Zealand Defence Policy - Policy - General, 1968

MoD 1/1/1 Vol. 3, New Zealand Defence Policy - Policy - General, 1968-1972

MoD 1/1/1 Vol. 4, New Zealand Defence Policy - Policy - General, 1972-1974

MoD 1/1/2 Vol. 1, New Zealand Defence Policy - Review of Defence Policy, 1964-1965

MoD 1/1/2 Vol. 2, New Zealand Defence Policy - Review of Defence Policy, 1965-1966

MoD 1/1/2 Vol. 3, New Zealand Defence Policy - Review of Defence Policy, 1964-1965

MoD 1/1/2 Vol. 4, New Zealand Defence Policy - Review of Defence Policy, 1968

MoD 1/1/2 Vol. 5, New Zealand Defence Policy - Review of Defence Policy, 1968-1969

MoD 1/1/2 Vol. 6, New Zealand Defence Policy - Review of Defence Policy, 1969

MoD 1/1/2 Vol. 7, New Zealand Defence Policy - Review of Defence Policy, 1970

MoD 1/1/2 Vol. 8, New Zealand Defence Policy - Review of Defence Policy, 1970-71

MoD 1/1/2 Vol. 9, New Zealand Defence Policy - Review of Defence Policy, 1972-1975

MoD 1/1/6 Vol. 1, New Zealand Defence Policy - NZ Defence Commitments, 1959-1968

MoD 1/1/6 Vol. 2, New Zealand Defence Policy - NZ Defence Commitments, 1968-1972

MoD 1/1/6 Vol. 3, New Zealand Defence Policy - NZ Defence Commitments, 1972-1974

MoD 1/1/9 Vol. 1, New Zealand Defence Policy - Talks and Arrangements with Allied Nations 1965-1966

MoD 1/1/9 Vol. 12, New Zealand Defence Policy - Talks and Arrangements with Allied Nations, 1969-1970

MoD 1/1/9 Vol. 13, New Zealand Defence Policy - Talks and Arrangements with Allied Nations, 1970-1971

\section{Archives New Zealand}

ABHS W5422 950 Box 34, 111/3/3/15 Vol. 8, International Security - Pacific Pact - ANZUS Council Meetings, 1968-70

ABHS W4627 Box 4072, 264/4/1 Vol. 22, China: Political Affairs - General, 1968-69

ABHS W4627 950 Box 4080, 264/4/14 33A, China: Political Affairs - Recognition of Communist China, 1971

ABHS W4627 950Box 4055, PM 264/2/2 11B China - External Relations - USA, 1971

ABHS W4628 6944 Box 8, HKG 82/1/1 Vol. 5, China - Political Affairs - General, 1970-73

ABHS W4628 6958 Box 46, NYP 3/16/1 Vol. 8, Political Affairs - China - General, 1971

ABHS W5579 6958 Box 121, NYP 3/16/3 Vol 2, Political Affairs - China - Hong Kong 19671997

ABHS W5400 20358 Box 148, KL 209/1/3 Vol. 2, China - Political Affairs - Recognition 1969-1985

ABHS W4628 6958 Box 46, NYP 3/16/1 Vol 5, Political Affairs - China - General, 1967 ABHS W4628 6958 Box 46, NYP 3/16/1 Vol 6, Political Affairs - China - General, 1967-68

ABFK W5767 19754 Box 125, 165/2/1 1, Hong Kong - Defence, 1948-56

ABFK 19754 W5767 Box 115, JSO 147/1/1 Vol. 2, South Vietnam - General, 1964-65

ACIE 8798 W2619 EAW2619 163 264/3/2 Vols. 1-6, Individual Countries - China - Political Affairs - Outlying Islands, 1954-1956 


\section{BIBLIOGRAPHY}

\subsection{NeWSPAPERS, MAGAZINES, AND UNPUBLISHED REPORTS}

'An Act to Establish the Ministry of Defence and to Provide a Unified Defence Policy for the Better Defence of New Zealand', NZ Parliament, November 1964, http://www.nzlii.org/nz/legis/hist_act/da19641964n6783/

'Defence White Paper 2010', New Zealand Ministry of Defence, November 2010, p. 15, http://www.nzdf.mil.nz/downloads/pdf/publicdocs/2010/defence_white_paper_2010.pdf

'Foreign Correspondents: The Tiny World of Anthony Grey', TIME Magazine, 20 December 1968, http://content.time.com/time/magazine/article/0,9171,844706,00.html

'U.S. Policy with Respect to Mainland China: Hearings Before the Committee on Foreign Relations, United States Senate, Eighty-ninth Congress, Second Session on U.S. Policy with Respect to Mainland China', March 8, 10, 16, 18, 21, 28, 30, 1966 (U.S.G.P.O, Washington, D.C., 1966)

Christchurch Star, 7 May 1976

The Economist, 14 January 1967;

The Sunday Telegraph, 1 January 1967;

The Times, 7 January 1967

Federation of American Scientists, 'DF-5', http://fas.org/nuke/guide/china/icbm/df-5.htm

Ministry of Defence (NZ). Armed Forces of New Zealand (Ministry of Defence, Wellington, 1986)

New Zealand China Friendship Society. 'New Zealand Should Recognise China: On the Grounds of Morality, Realism, National Interest. It Is Time to Look at the Facts Again' (Auckland, 1971)

US National Security Council, 'NSC 68: United States Objectives and Programs for National Security', 14 April 1950, http://fas.org/irp/offdocs/nsc-hst/nsc-68.htm

Bogunovic, B. 'The Storm in July', Politika, no date.

Kennan, George. 'The Long Telegram', US State Department Memo, 22 February 1946, http://www.trumanlibrary.org/whistlestop/study_collections/coldwar/documents/pdf/6 -6.pdf

Kennedy, John F. 'State of the Union', Speech, Washington, 14 February 1963, http://www.presidency.ucsb.edu/ws/?pid=9138

Nixon, Richard. Campaign Commercial, 1968, http://www.livingroomcandidate.org/commercials/1968/vietnam

Nixon, Richard. "Address to the Nation Announcing Conclusion of an Agreement on Ending the War and Restoring Peace in Vietnam," January 23, 1973. http://www.presidency.ucsb.edu/ws/?pid=3808

Richardson, Elliot L. 'The Foreign Policy of the Nixon Administration', Speech, American Political Science Association, 5 September 1969, 'Department of State Bulletin 61', 
No. 1567 ,

http://babel.hathitrust.org/cgi/pt?id=uc1.31158006191430;view=1up;seq=312

Templeton, Ian. 'Defence Review is Expected to be "Eggless Cake", Auckland Star, 7 April 1966

\subsection{BOOKS, ARTICLES, AND THESES}

'Five Power Defence Arrangements', New Zealand Foreign Affairs Review, Vol. 22, No. 1, January 1972

New Zealand Foreign Policy: Statements and Documents 1943-1957 (Ministry of Foreign Affairs, Wellington, 1972)

'Select Committee Report on China', New Zealand Foreign Affairs Review, Jan/Mar 1987, Vol. 37, No. 2, pp.16-18

Adshead, Samuel Adrian M. Debate on China, NZIIA Pamphlets, 6 (New Zealand Institute of International Affairs, Wellington, 1969)

Alley, Rewi. Rewi Alley: An Autobiography, 2nd ed (New World Press, Beijing, 1987)

Allison, Graham T. Essence of Decision: Explaining the Cuban Missile Crisis, 2nd ed (Longman, New York, 1999)

Atkinson, Joel. 'Australian Support for an Independent Taiwan Prior to the Recognition of the People's Republic of China', Australian Journal of Politics \& History, Vol. 57, 2011, pp. 68-85

Barnett, A. Doak. A New U.S. Policy Toward China (Brookings Institution, Washington, 1971)

Barnouin, Barbara and Yu Changgen, Chinese Foreign Policy During the Cultural Revolution, (Kegan Paul International, New York, 1998)

Barrington, Brook. 'New Zealand and the search for security 1944-1954: "a modest and moderate collaboration"', PhD Thesis, (University of Auckland, 1993)

Barrymaine, Norman. The Time Bomb: Today's China from the Inside (Taplinger, 1975)

Bassett, Michael. Tomorrow Comes the Song: A Life of Peter Fraser (Penguin, Auckland, 2000)

Belshaw, Sheila M. Man of Integrity: A Biography of Sir Clifton Webb (Dunmore Press, Palmerston North, 1979)

Bennett, Bruce S. and NZIIA. New Zealand's Moral Foreign Policy, 1935-1939: The Promotion of Collective Security Through the League of Nations (NZIIA, Wellington, 1988)

Berendsen, Carl, and Alister McIntosh. Undiplomatic Dialogue: Letters Between Carl Berendsen and Alister McIntosh, 1943-52 (Auckland University Press in association with the Ministry of Foreign Affairs and Trade and the Historical Branch, Dept. of Internal Affairs, Auckland, 1993)

Bertram, James M. Capes of China Slide Away: A Memoir of Peace and War, 1910-1980 (Auckland University Press, Auckland, 1993) 
Bing, Dov. (ed.). China: Cultural and Political Perspectives: A Selection of Papers Presented at the First New Zealand International Conference on Chinese Studies, University of Waikato, 1972 (Longman Paul, Auckland, 1975)

Bowen, George. History. 5, Topic, International Relations: Origins of World War II, 19191941; New Zealand's Search for Security, 1945-1985: Form Five (year Eleven) Student Notes (Longman, Auckland, 1997)

Bowles, Chester. 'The "China Problem" Reconsidered', Foreign Affairs, xxxviii, April 1960, p. $476-486$

Brady, Anne Marie. 'New Zealand-China Relations: Common Points and Differences', New Zealand Journal of Asian Studies, Vol. 10, No. 2, 2008, pp. 1-20

Brady, Anne Marie. 'The War that Never Was', in Trapeznik and Fox (eds.) Lenin's Legacy Down Under: New Zealand's Cold War (Oxford University Press, Dunedin, 2005) pp. 131-153

Brady, Anne-Marie. Friend of China - The Myth of Rewi Alley (Routledge Curzon, London, 2003)

Brewis, Melanie. Search for Security in the Nuclear Age, 1945 to the Present, History Workbook, (Heinemann Education, Auckland, 1992)

Bristow, Damon. 'The Five Power Defence Arrangements: Southeast Asia's Unknown Regional Security Organization', Contemporary Southeast Asia: A Journal of International and Strategic Affairs, Volume 27, Number 1, April 2005, pp. 1-20

Brown, Bruce. New Zealand Foreign Policy in Retrospect (1947-54 and the 1960s), NZIIA Pamphlets, No. 12, NZIIA, Wellington, 1970

Buszynski, Leszek. SEATO, the Failure of an Alliance Strategy (Singapore University Press, Singapore, 1983)

Cable, James. The Geneva Conference of 1954 on Indochina (Macmillan, Basingstoke, 2000)

Chin, Kin Wah. The Defence of Malaysia and Singapore: The Transformation of a Security System, 1957-1971. (Cambridge University Press, Cambridge, 1983)

von Clausewitz, Carl. On War, Translated by J.J. Graham, Revised by F.N. Maude \& Louise Willmot (Wordsworth Editions, Ware, 1997)

Clayton, Cathryn. 'The Hapless Imperialist? Portuguese Rule in 1960s Macau' in Bryna and David Goodman (eds.) Twentieth Century Colonialism and China: Localities, the everyday, and the world (Routledge, 2012)

Clubb, O. Edmund, Eustace Seligman, and Lyman M. Tondel (eds.). The International Position of Communist China; Background Papers and Proceedings (Published for the Association of the Bar of the City of New York by Oceana Publications, Dobbs Ferry, 1965)

Cohen, Warren. America's Response to China: A History of Sino-American Relations (CUP, New York, 2010)

Crawford, John. In the Field for Peace: New Zealand's Contribution to International Peacesupport Operations, 1950-1995 (New Zealand Defence Force, Wellington, 1996)

Dickens, David. 'New Zealand and the Vietnam War Official Policy Advice to the Government 1960-1972', PhD Thesis (Victoria University of Wellington, 1995) 
Dugard, John, and University of Cambridge, Recognition and the United Nations, Hersch Lauterpacht Memorial Lectures, 3 (Grotius, Cambridge, 1987)

Earle, Edward Mead. 'Introduction' in Edward Mead Earle (ed.) (Makers of Modern Strategy, Princeton University Press, Princeton, 1971) pp. vii-3

Earle, Edward Mead (ed.). Makers of Modern Strategy (Princeton University Press, Princeton, 1971)

Elder, Chris (ed.). Forty Years On: New Zealand-China relations then, now and in the years to come (VUP, Wellington, 2013)

Elder, Chris (ed.). New Zealand's China Experience: Its Genesis, Triumphs, and Occasional Moments of Less than Complete Success 1947-2012 (VUP, Wellington, 2014)

Elder, Chris, and Centre for Strategic Studies New Zealand, 'China's Rise and New Zealand's Interests: A Policy Primer for 2030', Discussion Paper, no. 11 (Centre for Strategic Studies: New Zealand, Victoria University of Wellington, Wellington, 2012)

Engerman, David C. Know Your Enemy: The Rise and Fall of America's Soviet Experts (OUP USA, New York, 2010)

Evans, Paul M. and B. Michael Frolic. Reluctant Adversaries: Canada and the People's Republic of China, 1949-1970 (University of Toronto Press, 1991)

Fenton, Damien. To Cage the Red Dragon, SEATO and the Defense of South East Asia 1955-1965 (National University of Singapore Press, Singapore, 2012)

Fenton, Damien Marc. A False Sense of Security: The Force Structure of the New Zealand Army 1946-1978 (CSS, Wellington, 1998)

Ferrall, Charles, Paul Millar, and Keren Smith (eds.). East by South: China in the Australasian Imagination (Victoria University Press, Wellington, 2005)

Fong, Ng Bickleen. The Chinese in New Zealand: A Study in Assimilation (Hong Kong University Press, Hong Kong, 1959)

Foot, Rosemary. 'US Hegemony and International Legitimacy: The Chinese Representation Issue at the United Nations' in The Practice of Power: US Relations with China since 1949 (Oxford Scholarship Online, 1997)

Freedman, Lawrence. 'Creating Power: Changing Character of War Program - 2010 Annual Lecture' (Oxford University, 2010)

Freedman, Lawrence. Strategy: A History (Oxford University Press, New York, 2013)

Fung, Edmund S. K. and Griffith University. Australia's Policy Towards the People's Republic of China, 1966 to 1969, Research Paper, No. 3, (Centre for the Study of Australian-Asian Relations, Griffith University, 1980)

Gaddis, John Lewis. Strategies of Containment: A Critical Appraisal of American National Security Policy During the Cold War, Revised and Expanded Edition (OUP, New York, 2005)

Galloway, Thomas. Recognizing Foreign Governments: The Practice of the United States, Studies in Foreign Policy (American Enterprise Institute, Washington, 1978)

Garnier, Tony. 'Changes in New Zealand Foreign Policy', New Zealand International Review, Vol. 1 No. 5, Sep/Oct 1976, pp.7-10 
Gilley, Bruce. 'Reawakening Canada's China Policy', Canadian Foreign Policy Journal, No. 14, 2008, pp. 121-130

Glackin, John Russell. 'New Zealand and Imperial Defence: The Development of New Zealand's Strategic Attitudes 1870-1893', MA Thesis (University of Canterbury, 1966)

Goodman, Bryna and David Goodman (eds.). Twentieth Century Colonialism and China: Localities, the everyday, and the world (Routledge, Milton Park, 2012)

Gordon, Bernard K. New Zealand Becomes a Pacific Power (University of Chicago Press, Chicago, 1960)

Grant, David. The Mighty Totara: The Life and Times of Norman Kirk (Random House, Auckland, 2014)

Gray, Colin S. Modern Strategy, (Oxford University Press, Oxford, 1999)

Greif, Stuart William. The Overseas Chinese in New Zealand (Asia Pacific Press, Singapore, 1974)

Gurtov, Melvin. 'The Foreign Ministry and Foreign Affairs during the Cultural Revolution', The China Quarterly, No. 40, Oct.-Dec. 1969, pp. 65-102

Gustafson, Barry. 'New Zealand and the Soviet Union' in New Zealand Foreign Policy and Defence (Olsen \& Webb, University of Otago, Dunedin, 1977)

Gustafson, Barry. His Way: A Biography of Robert Muldoon (Auckland University Press, Auckland, 2000)

Gustafson, Barry. Kiwi Keith: A Biography of Keith Holyoake (Auckland University Press, Auckland, 2007)

Hamilton, W.B. and Kenneth Robinson. A Decade of the Commonwealth 1955-1964, Duke University Commonwealth-Studies Center, No. 25 (Duke University Press, Durham, 1966)

Henderson, John, Keith Jackson, and Richard Kennaway (eds.). Beyond New Zealand: The Foreign Policy of a Small State (Methuen, Auckland, 1980)

Hensley, Gerald. Final Approaches: A Memoir (Auckland University Press, Auckland, 2006)

Holyoake, K. J. 'New Zealand and China', pamphlet (Ministry of Foreign Affairs, Wellington, 28 May 1971)

Holyoake, K. J. and New Zealand Institute of International Affairs, 'A Defence Policy for New Zealand: An Address', Pamphlet 3 (New Zealand Institute of International Affairs, Wellington, 1969)

Hunn, Jack. Not Only Affairs of State (Dunmore Press, Palmerston North, 1982)

Ip, Manying (ed.), Unfolding History, Evolving Identity: The Chinese in New Zealand (AUP, Auckland, 2003)

Ip, Manying (ed.). The Dragon \& the Taniwha: Mãori \& Chinese in New Zealand (AUP, Auckland, 2009)

Iriye, Akira, The Cold War in Asia: A Historical Introduction (Prentice-Hall, Englewood Cliffs, 1974) 
Irvine, Karen Leigh. 'New Zealand's Recognition of Communist China', BA (Hons) Dissertation (University of Otago, Dunedin, 1978)

Jeffery, Keith. MI6: The History of the Secret Intelligence Service 1909-1949 (Bloomsbury Paperbacks, 2011)

Jervis, Robert, Perception and Misperception in International Politics (Princeton University Press, Princeton, 1976)

Kaufman, Victor S. "Chirep': The Anglo-American Dispute over Chinese Representation in the United Nations, 1950-71', The English Historical Review, Vol. 115, No. 461, April 2000

Kautilya (traditionally). Arthashastra, R. Shamasastry (translator) (Government Press, Bangalore, 1915) https://en.wikisource.org/wiki/Arthashastra

Keith, Ken. \& NZIIA (eds.). Defence Perspectives: Papers Read at the 1972 Otago Foreign Policy School (Price Milburn, Wellington, 1972)

Kendall, Timothy. 'Using the Past to Serve the Present: Renewing Australia's Invasion Anxiety', in Ferrall, Millar, and Smith (eds.), East by South: China in the Australasian Imagination (Victoria University Press, Wellington, 2005) pp. 110-136

Kennaway, Richard. New Zealand Foreign Policy 1951-1971 (Hicks Smith, Wellington, 1972)

Kennan, George F. 'The Sources of Soviet Conduct,' Foreign Affairs, July 1947, https://en.wikisource.org/wiki/The Sources of Soviet_Conduct

Kennedy, Paul. 'Grand Strategy in War and Peace: Toward a Broader Definition' in Grand Strategy in War and Peace, Paul Kennedy (ed.) (Yale University Press, New Haven, 1991) pp. 1-11

Kennedy, Paul (ed.). Grand Strategy in War and Peace, (Yale University Press, New Haven, 1991)

Khrushchev, Nikita Sergeevich. Khrushchev Remembers, with an Introduction, Commentary and Notes by Edward Crankshaw, trans. by Strobe Talbott, 2nd ed (Brown \& Company, Little, 1971)

Kirk, Norman, 'New Directions in New Zealand's Foreign Policy', Millennium - Journal of International Studies, No. 3, 1974, pp. 91-99

Kissinger, Henry. On China, Kindle Edition (Penguin, London, 2011)

Kissinger, Henry. The White House Years (Brown \& Co, Boston, 1979)

Kuisong, Y. 'The Sino-Soviet Border Clash of 1969: From Zhenbao Island to SinoAmerican Rapprochement', Cold War History, Vol. 1, No. 1, 2000

Laffey, Mark Andrew. Sovereignty and Security: New Zealand's International Relations Since 1945 (Heinemann Education, Auckland, 1990)

Laking, George R. 'International Problems Confronting New Zealand in the 1970s', in Brown, Bruce (ed.) New Zealand and Australia: Foreign Policy in the 1970s (Price Milburn, 1970)

Laking, G. R. and NZIIA. New Zealand and Australia: Foreign Policy in the 1970's (Price Milburn, Wellington, 1970) 
Larkin, T.C. (ed.) New Zealand's External Relations (New Zealand Institute of Public Administration, Wellington, 1962)

Lauterpacht, Hersh. Recognition in International Law (Cambridge University Press, Cambridge, 1947)

Leathem, Samuel, New Zealand Institute of International Affairs, and Institute of Pacific Relations (U.S.). 'New Zealand's Interests and Policies in the Far East', New Zealand Paper, No. 1 (New Zealand Institute of International Affairs, Distributed by International Secretariat, Institute of Pacific Relations, Wellington, New York, 1950)

Lee, David, and Stuart Doran. Australia's Recognition of the People's Republic of China (Australian Government - Department of Foreign Affairs \& Trade, 2002)

Liddell Hart, B. H. Strategy, $2^{\text {nd }}$ edition (Faber \& Faber, London, 1991)

Lynch, Brian (ed.). Celebrating 75 Years: New Zealand Institute of International Affairs (New Zealand Institute of International Affairs, Wellington, 2010)

Lynch, Brian, Celebrating New Zealand's Emergence: A Tribute to Sir George Laking and Frank Corner (New Zealand Institute of International Affairs, Victoria University of Wellington, Wellington, 2005)

Macfarquhar, Roderick. 'China: The Balance of Forces', The New Statesman, Vol. 73, January 1967. p. 31

MacFarquhar, Roderick and Michael Schoenhals. Mao's Last Revolution (Belknap Press, Cambridge, 2008)

Macfarquhar, Roderick. The Origins of the Cultural Revolution, Vols. 1-3, (CUP, New York, 1974, 1983, 1999)

Majid, Harun Abdul. Rebellion in Brunei: The 1962 Revolt, Imperialism, Confrontation and Oil (I. B. Tauris, London, 2007)

Mao, Zedong. 'Talks at a Conference of Secretaries of Provincial, Municipal and Autonomous Region Party Committees', 18 January 1957, in Selected Works, Vol. 1, (Foreign Languages Press, Beijing, 1977)

Mao, Zedong. Mao Tse-tung: Interview with the British Journalist James Bertram (Foreign Language Press, Peking, 1968)

McCraw, David J, 'The Zenith of Realism in New Zealand's Foreign Policy', Australian Journal of Politics \& History, No. 48, 2002, pp. 353-368

McCraw, David J. 'New Zealand's Foreign Policy Under National and Labour Governments: Variations on the "Small State" Theme?', Pacific Affairs, No. 67, 1994, pp. $7-25$

McCraw, David. 'Objectives and Priorities in New Zealand's Foreign Policy in Asia 194975: A Study of the Issue of the Recognition of the People's Republic of China and of Security Policies in South-East Asia', PhD Thesis (University of Otago, Dunedin, 1978)

McGibbon, I. C. New Zealand's Vietnam War: A history of combat, commitment and controversy, (Exile, Auckland, 2010)

McGibbon, I. C. New Zealand and the Korean War Volume I (Oxford University Press in association with the Historical Branch, Dept. of Internal Affairs, Auckland, 1992) 
McGibbon, I. C. 'Forward Defence: The South East Asian Commitment' in Malcolm McKinnon (ed.) New Zealand in World Affairs Volume 2: 1957-1972 (NZIIA, Wellington, 1991) pp. 9-40

McGibbon, I. C. 'The Defence of New Zealand 1945-1957', in New Zealand in World Affairs Volume 1: 1945 1957, 2nd ed (Price Milburn, Wellington, 1991) pp. 143-177

McGibbon, I. C. and Paul William Goldstone (eds.). The Oxford Companion to New Zealand Military History (Oxford University Press, Auckland, Melbourne, Oxford, 2000)

McGibbon, I. C, (ed.). Unofficial Channels: Letters Between Alister McIntosh and Foss Shanahan, George Laking and Frank Corner, 1946-1966 (Victoria University Press in association with the Ministry of Foreign Affairs and Trade and the Historical Branch, Dept. of Internal Affairs, Wellington, 1999)

McGibbon, I. C. \& John Crawford (eds.). Seeing Red: New Zealand, the Commonwealth and the Cold War 1945-91 (NZ Military History Committee, Wellington, 2012)

McIntosh, A. D. 'Administration of an Independent New Zealand Foreign Policy', in T.C. Larking (ed.) New Zealand's External Relations (OUP, Wellington, 1962) pp. 30-61

McIntosh, A. D. (ed.) New Zealand in World Affairs 1945-1957 (New Zealand Institute of International Affairs, Wellington, 1977)

McIntosh, Sir Alister. 'Origins of the Department of External Affairs and Formation of an Independent Foreign Policy, in New Zealand in World Affairs: Volume 1 1945-1957 (NZIIA, Wellington, 1977) pp. 9-37

McIntyre, W. David. Background to the ANZUS Pact: Policy-Making, Strategy and Diplomacy, 1945-55 (St Martin's \& CUP, Christchurch, 1995)

McIntyre, W. David (William David). 'Britain, New Zealand and the Security of South-East Asia in the 1970's', NZIIA pamphlets, No. 5, 1969

McKinnon, Malcolm. Independence and Foreign Policy: New Zealand in the World Since 1935 (Auckland University Press, Auckland, 1993)

McKinnon, Malcolm (ed.). New Zealand in World Affairs 1957-1972 (New Zealand Institute of International Affairs, Wellington, 1991)

McKnight, David, 'Western Intelligence and SEATO's War on Subversion, 1956-63', Intelligence and National Security, No. 20, 2005, pp. 288-303

McNeish, James. Dance of the Peacocks (Vintage, Auckland, 2003)

Medvedev, Roy A. China and the Superpowers (Blackwell, Oxford, 1986)

Milner, Ian Frank George. New Zealand's Interests and Policies in the Far East (New York, 1939)

Misra, K. P. India's Policy of Recognition of States and Governments (Allied Publishers, Bombay, 1966)

Monk, W. F. 'The Impact of Asia: New Zealand Faces North', Pacific Affairs, Vol. 26, No. 3, September 1953, pp. 220-229

Munro, L. K., 'New Zealand and the New Pacific', Foreign Affairs (pre-1986), No. 31, 1953, p. 634 
Murdoch, Anthony, Pam O'Connell and John Rosanowski. New Zealand's Search for Security, 1945-1985 (Longman Paul, Auckland, 1986)

Nathan, Andrew J. and Andrew Scobell. China's Search for Security, 2nd ed (Columbia University Press, 2012)

Newman, Robert P. Recognition of Communist China? A Study in Argument (Macmillan, New York, 1961)

Ng, James. The Chinese in New Zealand: A Bibliography (Dunedin, 1962)

$\mathrm{Ng}$, James, and Amity Centre Publishing Project. Chinese Settlement in New Zealand, Past and Present: Ng Fon and His Family in New Zealand (Amity Centre Publishing Project, Dunedin, 2001)

Nixon, Richard M. 'Asia After Viet Nam', Foreign Affairs, October 1967, https://www.foreignaffairs.com/articles/asia/1967-10-01/asia-after-viet-nam

Northey, J.F. 'Foreign Policy for Australia and New Zealand', International Journal, Vol. 6, No. 3, Summer 1951, pp. 197-206

Nunes, Ray. The Truth About Vietnam, Laos, Malaysia and Indonesia (National Secretariat, Communist Party of New Zealand, Auckland, 1964)

O'Brien, Terence. Presence of Mind: New Zealand in the World (New Zealand Institute of International Affairs, Wellington, 2009)

Olssen, Erik, and W. W. Webb (eds.). New Zealand Foreign Policy and Defence, 12-15 May, 1977 (Dept. of University Extension, University of Otago, Dunedin, 1977)

Ovendale, R. 'Britain, the United States, and the Recognition of Communist China', The Historical Journal, Vol. 26, 1983, pp. 139-158

Pearson, Mark Julius and New Zealand Institute of International Affairs, Paper Tiger: New Zealand's Part in SEATO, 1954-1977 (New Zealand Institute of International Affairs, Wellington, 1989)

Power, T. 'New Zealand and the Korean War', Political Science, No. 16, 1964, pp. 52-70

Pugsley, Christopher. From Emergency to Confrontation: The New Zealand Armed Forces in Malaya and Borneo 1949-1966 (Oxford University Press, Oxford, 2003)

Qiang, Zhai. 'China and the Geneva Conference of 1954', The China Quarterly, No. 129, March 1992, pp. 103-122

Rabel, Roberto Giorgio. New Zealand and the Vietnam War: Politics and Diplomacy (Auckland University Press, Auckland, 2005)

Rabel, Roberto. 'New Zealand and the United States in the Early Cold War Era, 1945-49', Australasian Journal of American Studies, Vol. 7, 1988, pp. 1-10

Robinson, Alan. Australia and New Zealand: The Search for New Security Policies (New Zealand Institute of International Affairs, Wellington, 1970)

Rolfe, Jim. Anachronistic Past or Positive Future: New Zealand and the Five Power Defence Arrangements, CSS Working Paper 4/95, (CSS, Wellington, 1995)

Rolfe, James (James Grant). The Armed Forces of New Zealand. (Allen \& Unwin, St. Leonards, 1999) 
Rolfe, Jim. 'New Zealand Defence Policy During the Cold War', in Trapeznik and Fox (eds.) Lenin's Legacy Down Under: New Zealand's Cold War (University of Otago Press, Dunedin, 2004)

Rothfels, H. 'Clausewitz' in Edward Mead Earle (ed.) Makers of Modern Strategy (Princeton University Press, Princeton, 1971) pp. 93-117

Roy, W. T. 'New Zealand's China Policies: A Review and a Prospect', in D. Bing (ed.) China: Cultural and Political Perspectives (Longman Paul, Auckland, 1975)

Schlesinger, Stephen C. Act of Creation: The Founding of the United Nations (Westview Press, Cambridge, 2003)

Scholefield, Guy H. and T.D.H. Hall. Asiatic Immigration in New Zealand: Its History and Legislation (Institute of Pacific Relations, Honolulu, 1927)

Schonberger, Howard. 'Peacemaking in Asia: The United States, Great Britain, and the Japanese Decision to Recognize Nationalist China, 1951-52', Diplomatic History, Vol. 10, No. 1, January 1986, pp. 59-73

Scott, John. 'Recognising China' in McKinnon, Malcolm. (ed.), New Zealand in World Affairs Volume II 1957-1972, NZIIA, Wellington, 1991

Shaw, Geoffrey D.T. 'The Canadian Armed Forces and Unification', Defence Analysis, Vol. 17, No. 2, p. 160

Shaw, Alick, and Terry S Auld (eds.). Background to China's Foreign Policy Today (Wellington Branch New Zealand China Society, Wellington, 1976)

Shuker, Roy Gordon. 'New Zealand Policy and Attitudes Toward Communist China', MA Thesis (VUW, January 1971)

Sinclair, Keith. New Zealand in the World Since 1945 (Heinemann Educational, Auckland, 1970)

Sinclair, Keith. Towards Independence: International Relations: New Zealand in the World Since 1945 (Heinemann Educational, Auckland, 1975)

Sinclair, Keith. Walter Nash (Auckland University Press, Oxford University Press, Auckland, 1976)

Smith, Anthony L. (ed.) Southeast Asia and New Zealand: A History of Regional and Bilateral Relations (Institute of Southeast Asian Studies, Singapore, New Zealand Institute of International Affairs in association with Victoria University Press, Wellington, 2005)

Smith, Daiman. 'Official Attitudes Towards China Between 1945 and 1957: The Development of the Non-Recognition Policy', MA Thesis (Massey University, 1997)

Stenson, Michael. 'Forward Defence in Asia' in New Zealand in World Affairs Volume 1: 1945-1957, Price Milburn, Wellington, 2nd Edition, 1991, p. 177-199;

Stevenson, Adlai. 'Putting First Things First', Foreign Affairs, xxxviii, January 1960

Sun Tzu. The Art of War, John Minford (translator) (Penguin, London, 2002)

Sutch, W. B, The Quest for Security in New Zealand, 1840 to 1966 (Oxford University Press, Wellington, 1966) 
Tai, Yuen, and New Zealand Asia Institute. The Origins of China's Awareness of New Zealand, 1674-1911 (New Zealand Asia Institute, University of Auckland, Auckland, 2005)

Taylor, Claire. 'A Brief Guide to Previous British Defence Reviews', Report SN/IA/5714, House of Commons Library, 19 October 2010, http://www.parliament.uk/briefingpapers/SN05714.pdf

Templeton, Malcolm (ed.). An Eye, an Ear and a Voice: 50 Years in New Zealand's External Relations 1943-1993 (MFAT, Wellington 1993)

Templeton, Malcolm (ed.). New Zealand as an International Citizen: Fifty Years of United Nations Membership (Ministry of Foreign Affairs and Trade, Wellington, 1995)

Templeton, Malcolm. Standing Upright Here: New Zealand in the Nuclear Age 1945-1990 (Victoria University Press, in association with the New Zealand Institute of International Affairs, Wellington, 2006)

Trapeznik, Alexander, and Aaron Patrick Fox (eds.). Lenin's Legacy Down Under: New Zealand's Cold War (University of Otago Press, Dunedin, 2004)

Trotter, Ann (ed.). New Zealand and China: The Papers of the Twenty-First Foreign Policy School 1986 (Foreign Policy School Series, University of Otago, Dunedin, 1986)

Umetsu, Hiroyuki. 'The Origins of the British Commonwealth Strategic Reserve: The UK Proposal to Revitalise ANZAM and the increased Australian Defence Commitment to Malaya', Australian Journal of Politics and History, Vol. 50, No. 4, 2004, pp. 509525

Walker, Darryl and John Henderson. 'China: A Study in Changed Perceptions', in Henderson et. al. (eds.) Beyond New Zealand: Foreign Policy of a Small State (Methuen, Auckland, 1980) pp. 195-198

Wang, Gungwu. The Re-emergence of China: A Paper Read to the University of Otago Extension Foreign Policy School May 1973, NZIIA Pamphlets 26 (New Zealand Institute of International Affairs, Wellington, 1973)

Wilson, A. C. New Zealand and the Soviet Union, 1950-1991: A Brittle Relationship (Victoria University Press in association with the New Zealand Institute of International Affairs, Wellington, 2004)

Wirtz, James J. The Tet Offensive: Intelligence Failure in War (Cornell University Press, Ithaca, 1991)

Wolf, David C. 'To Secure a Convenience': Britain Recognizes China - 1950', Journal of Contemporary History, Vol. 18, No. 2, April, 1983, pp. 299-326

Wood, F.L.W. 'The ANZAC Dilemma', International Affairs, Royal Institute of International Affairs, Vol. 29, No. 2, April 1953, pp. 184-192

Wood, F.L.W. 'Report From New Zealand', Pacific Affairs, Vol. 22, No. 1, March 1949, pp. $38-40$

Xia, Yafeng. Negotiating with the Enemy: U.S.-China Talks During the Cold War, 19491972 (Indiana University Press, Bloomington, September 2006)

Yep, Ray and Robert Bickers (eds.). May Days in Hong Kong: Riot and Emergency in 1967 (Hong Kong University Press, Hong Kong, 2009) 
Young, Thomas-Durell. Australian, New Zealand, and United States Security Relations, 1951-1986, Studies in Global Security (Westview Press, Boulder, 1992)

Zhang, Beihua. 'Sino-New Zealand Relations 1792-1987', MPhil Thesis (University of Waikato, Hamilton, 1988) 